National Water-Quality Assessment Program

\title{
Nutrient and Suspended-Sediment Trends in the Missouri River Basin, 1993-2003
}

Scientific Investigations Report 2006-5231 


\section{Nutrient and Suspended-Sediment Trends in the Missouri River Basin, 1993-2003}

By Lori A. Sprague, Melanie L. Clark, David L. Rus, Ronald B. Zelt, Jennifer L. Flynn, and Jerri V. Davis

National Water-Quality Assessment Program

Scientific Investigations Report 2006-5231 


\section{U.S. Department of the Interior DIRK KEMPTHORNE, Secretary}

\section{U.S. Geological Survey \\ Mark D. Myers, Director}

\section{U.S. Geological Survey, Reston, Virginia: 2007}

For product and ordering information:

World Wide Web: http://www.usgs.gov/pubprod

Telephone: 1-888-ASK-USGS

For more information on the USGS--the Federal source for science about the Earth, its natural and living resources, natural hazards, and the environment:

World Wide Web: http://www.usgs.gov

Telephone: 1-888-ASK-USGS

Any use of trade, product, or firm names is for descriptive purposes only and does not imply endorsement by the U.S. Government.

Although this report is in the public domain, permission must be secured from the individual copyright owners to reproduce any copyrighted materials contained within this report.

Suggested citation:

Sprague, L.A., Clark, M.L., Rus, D.L., Zelt, R.B., Flynn, J.L., and Davis, J.V., 2006, Nutrient and Suspended-Sediment Trends in the Missouri River Basin, 1993-2003: U.S. Geological Survey Scientific Investigations Report 2006-5231, $80 \mathrm{p}$. 


\section{Foreword}

The U.S. Geological Survey (USGS) is committed to providing the Nation with credible scientific information that helps to enhance and protect the overall quality of life and that facilitates effective management of water, biological, energy, and mineral resources (http://www.usgs.gov/). Information on the Nation's water resources is critical to ensuring long-term availability of water that is safe for drinking and recreation and is suitable for industry, irrigation, and fish and wildlife. Population growth and increasing demands for water make the availability of that water, now measured in terms of quantity and quality, even more essential to the long-term sustainability of our communities and ecosystems.

The USGS implemented the National Water-Quality Assessment (NAWQA) Program in 1991 to support national, regional, State, and local information needs and decisions related to water-quality management and policy (http://water.usgs.gov/nawqa). The NAWQA Program is designed to answer: What is the condition of our Nation's streams and ground water? How are conditions changing over time? How do natural features and human activities affect the quality of streams and ground water, and where are those effects most pronounced? By combining information on water chemistry, physical characteristics, stream habitat, and aquatic life, the NAWQA Program aims to provide science-based insights for current and emerging water issues and priorities. From 1991-2001, the NAWQA Program completed interdisciplinary assessments and established a baseline understanding of water-quality conditions in 51 of the Nation's river basins and aquifers, referred to as Study Units (http://water.usgs.gov/nawqa/ studyu.html).

In the second decade of the Program (2001-2012), a major focus is on regional assessments of water-quality conditions and trends. These regional assessments are based on major river basins and principal aquifers, which encompass larger regions of the country than the Study Units. Regional assessments extend the findings in the Study Units by filling critical gaps in characterizing the quality of surface water and ground water, and by determining status and trends at sites that have been consistently monitored for more than a decade. In addition, the regional assessments continue to build an understanding of how natural features and human activities affect water quality. Many of the regional assessments employ modeling and other scientific tools, developed on the basis of data collected at individual sites, to help extend knowledge of water quality to unmonitored, yet comparable areas within the regions. The models thereby enhance the value of our existing data and our understanding of the hydrologic system. In addition, the models are useful in evaluating various resource-management scenarios and in predicting how our actions, such as reducing or managing nonpoint and point sources of contamination, land conversion, and altering flow and (or) pumping regimes, are likely to affect water conditions within a region.

Other activities planned during the second decade include continuing national syntheses of information on pesticides, volatile organic compounds (VOCs), nutrients, selected trace elements, and aquatic ecology; and continuing national topical studies on the fate of agricultural chemicals, effects of urbanization on stream ecosystems, bioaccumulation of mercury in stream ecosystems, effects of nutrient enrichment on stream ecosystems, and transport of contaminants to public-supply wells.

The USGS aims to disseminate credible, timely, and relevant science information to address practical and effective waterresource management and strategies that protect and restore water quality. We hope this NAWQA publication will provide you with insights and information to meet your needs, and will foster increased citizen awareness and involvement in the protection and restoration of our Nation's waters.

The USGS recognizes that a national assessment by a single program cannot address all water-resource issues of interest. External coordination at all levels is critical for cost-effective management, regulation, and conservation of our Nation's water resources. The NAWQA Program, therefore, depends on advice and information from other agencies-Federal, State, regional, interstate, Tribal, and local — as well as nongovernmental organizations, industry, academia, and other stakeholder groups. Your assistance and suggestions are greatly appreciated.

Robert M. Hirsch

Associate Director for Water 


\section{Contents}

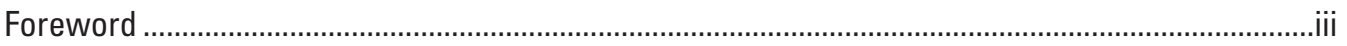

Abstract

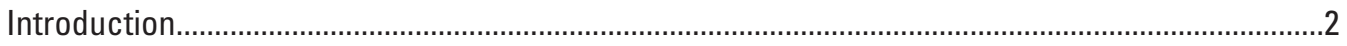

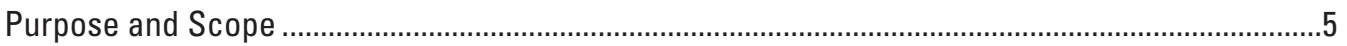

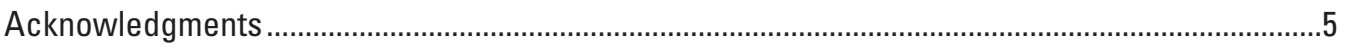

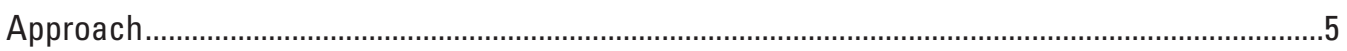

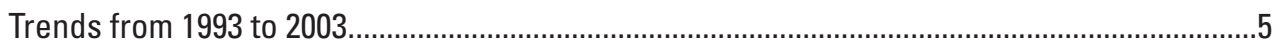

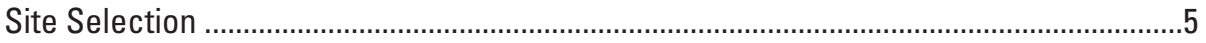

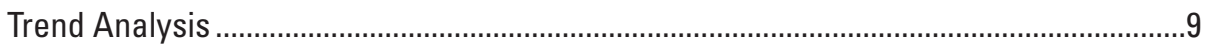

Flow-Adjusted Trends in Concentration.............................................................

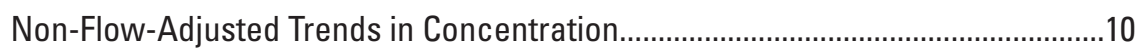

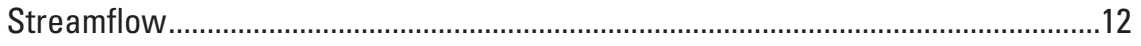

Changes in Nutrient Sources and Landscape Characteristics from 1993-2003..............12

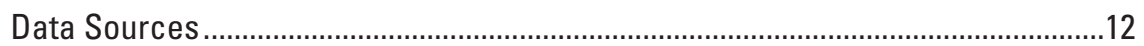

Relating Trends and Factors Affecting Trends....................................................14

Scale-Dependency in Relating Trends and Factors Affecting Trends.....................14

Trends from 1985 to 2003 ..................................................................................................

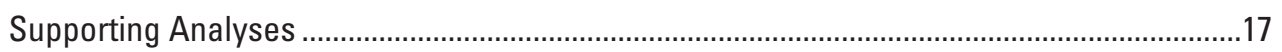

Effect of Ground Water on Surface-Water Nitrate Trends ...........................................17

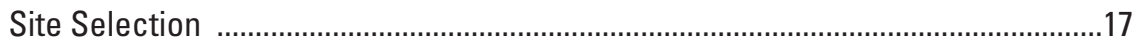

Ground-Water Discharge and Load Estimation ......................................................17

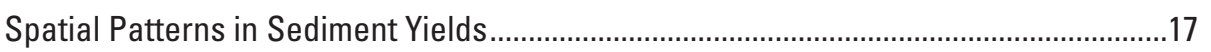

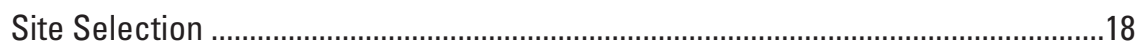

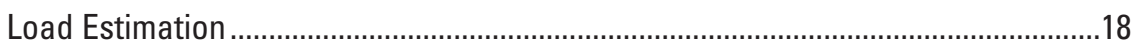

Comparison of Sediment Yields to Landscape Characteristics .................................18

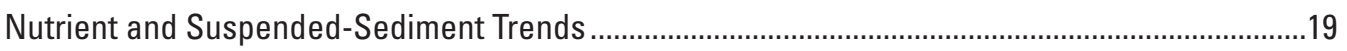

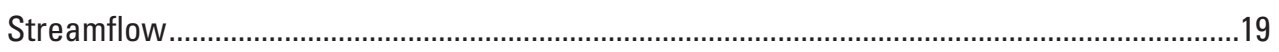

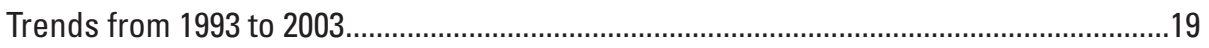

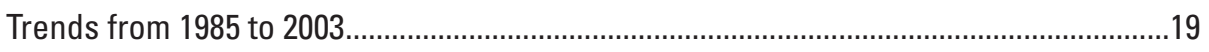

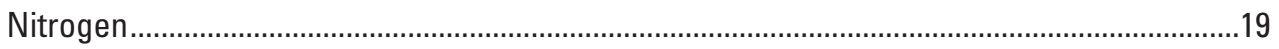

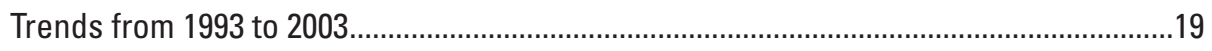

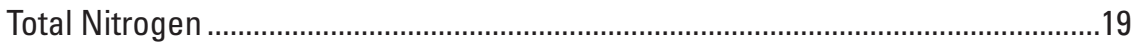

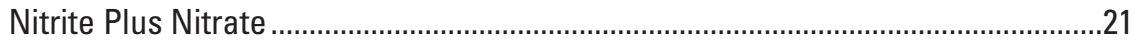

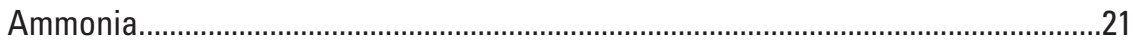

Changes in Nutrient Sources and Landscape Characteristics

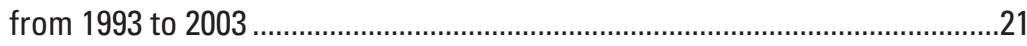

Effect of Ground Water on Surface-Water Nitrate Trends ....................................26

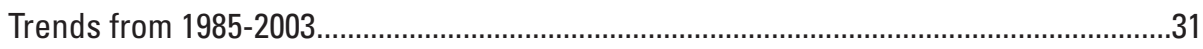

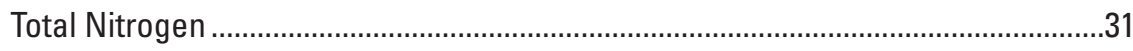

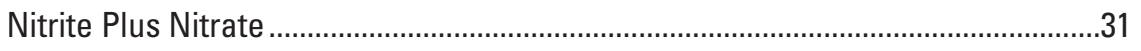

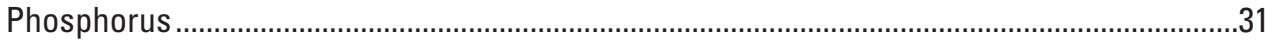

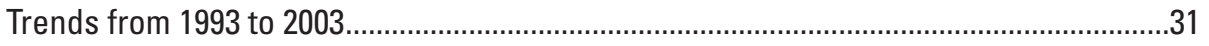




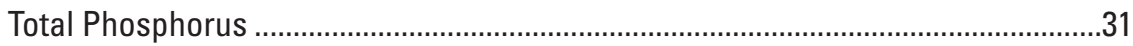

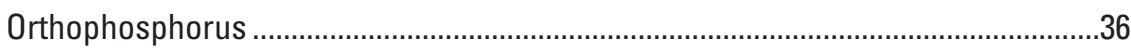

Changes in Nutrient Sources and Landscape Characteristics from

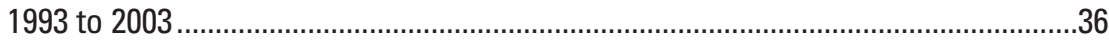

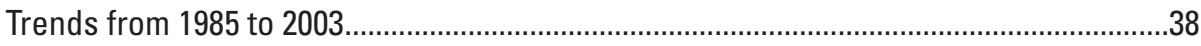

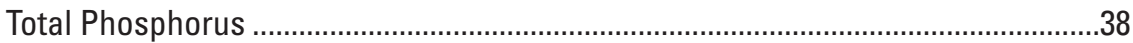

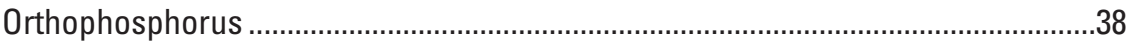

Suspended Sediment ......................................................................................................

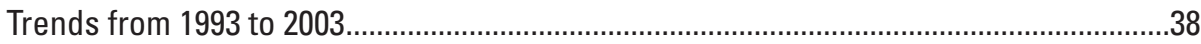

Changes in Landscape Characteristics from 1993 to 2003 ....................................43

Trends from 1985 to 2003.............................................................................................

Spatial Patterns in Sediment Yield ..............................................................................43

Implications for Management of Water Resources in the Missouri River Basin ............................48

Summary and Conclusions......................................................................................................... 49

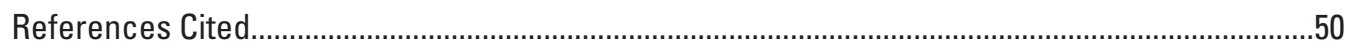

Appendix 1. Description of methods used to derive estimates of nitrogen loading from point sources ................................................................................................57

Appendix 2. Custom algorithm used to extract a target percentage of the total

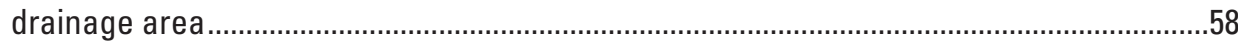

Appendix 3. Model output for trends in mean monthly streamflow from 1993 to 2003 .................64

Appendix 4. Model output for flow-adjusted trends in concentration from

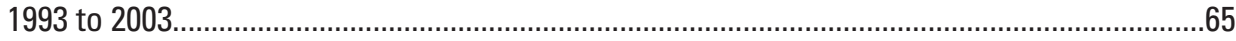

Appendix 5. Model output for non-flow-adjusted trends in concentration from 1993 to 2003 ...........................................................................................................

Appendix 6. Model output for nitrate loads in surface water and base flow

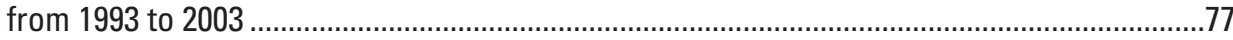

Appendix 7. Model output for flow-adjusted trends in concentration

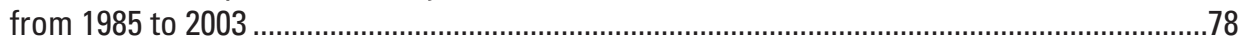

Appendix 8. Model output for suspended-sediment loads .........................................................

\section{Figures}

1. Map showing location of National-Water Quality Assessment Program study areas within the Missouri River Basin and sites included in trend analysis................

2. Maps showing distribution of $(A)$ land use and $(B)$ physiographic provinces in the Missouri River Basin.

3. Map showing trends in streamflow from 1993 to 2003 at selected locations in the Missouri River Basin.

4. Graphs showing daily mean discharge at selected locations in the Missouri River Basin from 1985 to 2003, with a LOWESS curve

5. Flow-adjusted and non-flow-adjusted trends in concentration of $(A, B)$ total nitrogen, $(C, D)$ nitrite plus nitrate, and $(E, F)$ ammonia from 1993 to 2003 at selected locations in the Missouri River Basin. 
6-11. Graphs showing:

6. (A) Flow-adjusted and $(B)$ non-flow-adjusted trends in concentrations of total nitrogen compared to changes in nutrient sources and landscape characteristics from 1993 to 2003

7. (A) Flow-adjusted and $(B)$ non-flow-adjusted trends in concentrations of nitrite plus nitrate compared to changes in nutrient sources and landscape characteristics from 1993 to 2003

8. (A) Flow-adjusted and $(B)$ non-flow-adjusted trends in concentrations of ammonia compared to changes in nutrient sources and landscape characteristics from 1993 to 2003

9. (A) Base-flow contribution to streamflow from 1993 to 2003 and $(B)$ total annual surface-water and base-flow loads of nitrite plus nitrite from 1993 to 2003 at three sites in the Missouri River Basin.

10. Flow-adjusted trends in concentrations of total nitrogen from 1985 to 2003

11. Flow-adjusted trends in concentrations of nitrite plus nitrate from 1985 to 2003

12. Maps showing flow-adjusted and non-flow-adjusted trends in concentrations of $(A, B)$ total phosphorus and $(C, D)$ orthophosphorus from 1993 to 2003 at selected locations in the Missouri River Basin.

13-16. Graphs showing:

13. (A) Flow-adjusted and $(B)$ non-flow-adjusted trends in concentrations of total phosphorus compared to changes in nutrient sources and landscape characteristics from 1993 to 2003

14. ( $A)$ Flow-adjusted and $(B)$ non-flow-adjusted trends in concentrations of orthophosphorus compared to changes in nutrient sources and landscape characteristics from 1993 to 2003

15. Flow-adjusted trends in concentrations of total phosphorus from 1985 to 2003

16. Flow-adjusted trends in concentrations of orthophosphorus from 1985 to 2003

17. Maps showing $(A)$ Flow-adjusted and $(B)$ non-flow-adjusted trends in concentrations of suspended sediment from 1993 to 2003 at selected locations in the Missouri River Basin

18. Graphs showing $(A)$ Flow-adjusted and $(B)$ non-flow-adjusted trends in concentrations of suspended sediment compared to changes in landscape characteristics from 1993 to 2003

19. Graphs showing flow-adjusted trends in concentrations of suspended sediment from 1985 to 2003

20. Map showing yields of suspended sediment at selected locations in the Missouri River Basin.

21. Graphs showing suspended-sediment yields compared to changes in landscape characteristics.

\section{Tables}

Table 1. Basin characteristics and trend coverage of study sites in the Missouri River

Basin, 1993-2003 
Table 2. Sources, types, and temporal coverage of data on nutrient sources and landscape characteristics in the Missouri River Basin.

Table 3. Summary of weighted least-squares regressions of mean daily sediment yields and landscape characteristics

\title{
Abbreviations
}

\author{
AIC Akaike information criterion \\ $\mathrm{AR}(20) \quad$ autoregressive process of order 20 \\ BMP best management practice \\ FA flow-adjusted \\ GIS geographic information system \\ KN Kjeldahl nitrogen \\ LOWESS locally weighted, scatterplot smoothing \\ LRL laboratory reporting level \\ MDL method detection limit \\ MDSY mean daily sediment yield \\ NAWQA National Water-Quality Assessment Program \\ NFA non-flow-adjusted \\ NH3 ammonia \\ NOX nitrite plus nitrate \\ NRI Natural Resources Conservation Service National Resources Inventory \\ NWIS U.S. Geological Survey National Water Information System database \\ NWQL U.S. Geological Survey National Water-Quality Laboratory \\ OP orthophosphorus \\ SS suspended sediment \\ STATSGO State Soils Geographic Database \\ TN total nitrogen \\ TP total phosphorus \\ USGS U.S. Geological Survey
}




\section{Conversion Factors}

\begin{tabular}{lcc}
\hline Multiply & By & To obtain \\
\hline centimeter $(\mathrm{cm})$ & Length & inch (in) \\
meter $(\mathrm{m})$ & 0.3937 & foot $(\mathrm{ft})$ \\
kilometer $(\mathrm{km})$ & 3.281 & mile $(\mathrm{mi})$ \\
\hline & 0.6214 & \\
\hline square kilometer $\left(\mathrm{km}^{2}\right)$ & Area & acre \\
square meter $\left(\mathrm{m}^{2}\right)$ & 247.1 & square foot $\left(\mathrm{ft}^{2}\right)$ \\
square kilometer $\left(\mathrm{km}^{2}\right)$ & 10.76 & square mile $\left(\mathrm{mi}^{2}\right)$ \\
\hline & 0.3861 & acre-foot $($ acre-ft) \\
\hline cubic meter $\left(\mathrm{m}^{3}\right)$ & Volume & acre-foot per day $(\mathrm{acre}-\mathrm{ft} / \mathrm{d})$ \\
\hline cubic meter per second $\left(\mathrm{m}^{3} / \mathrm{s}\right)$ & 0.0008107 & cubic foot per second $\left(\mathrm{ft}^{3} / \mathrm{s}\right)$ \\
cubic meter per second $\left(\mathrm{m}^{3} / \mathrm{s}\right)$ & Flow rate & \\
\hline kilogram $(\mathrm{kg})$ & 70.07 & pound avoirdupois $(\mathrm{lb})$ \\
\hline kilogram per square kilometer $\left(\mathrm{kg} / \mathrm{km}^{2}\right)$ & 35.31 & Mass \\
\hline
\end{tabular}

Temperature in degrees Celsius $\left({ }^{\circ} \mathrm{C}\right)$ may be converted to degrees Fahrenheit $\left({ }^{\circ} \mathrm{F}\right)$ as follows:

$$
{ }^{\circ} \mathrm{F}=\left(1.8 \mathrm{x}^{\circ} \mathrm{C}\right)+32 \text {. }
$$

Temperature in degrees Fahrenheit $\left({ }^{\circ} \mathrm{F}\right)$ may be converted to degrees Celsius $\left({ }^{\circ} \mathrm{C}\right)$ as follows:

$$
{ }^{\circ} \mathrm{C}=\left({ }^{\circ} \mathrm{F}-32\right) / 1.8 \text {. }
$$

Vertical coordinate information is referenced to the North American Vertical Datum of 1988 (NAVD 88).

Horizontal coordinate information is referenced to the North American Datum of 1983 (NAD 83).

Altitude, as used in this report, refers to distance above the vertical datum.

Concentrations of chemical constituents in water are given either in milligrams per liter (mg/L) or micrograms per liter $(\mu \mathrm{g} / \mathrm{L})$. 


\title{
Nutrient and Suspended-Sediment Trends in the Missouri River Basin, 1993-2003
}

\author{
By Lori A. Sprague, Melanie L. Clark, David L. Rus, Ronald B. Zelt, Jennifer L. Flynn, and Jerri V. Davis
}

\section{Abstract}

Trends in streamflow and concentration of total nitrogen, nitrite plus nitrate, ammonia, total phosphorus, orthophosphorus, and suspended sediment were determined for the period from 1993 to 2003 at selected stream sites in the Missouri River Basin. Flow-adjusted trends in concentration (the trends that would have occurred in the absence of natural changes in streamflow) and non-flow-adjusted trends in concentration (the overall trends resulting from natural and human factors) were determined. In the analysis of flow-adjusted trends, the removal of streamflow as a variable affecting concentration allowed trends caused by other factors such as implementation of best management practices to be identified. In the analysis of non-flow-adjusted trends, the inclusion of any and all factors affecting concentration allowed trends affecting aquatic ecosystems and the status of streams relative to water-quality standards to be identified. Relations between the flow-adjusted and non-flow-adjusted trends and changes in streamflow, nutrient sources, ground-water inputs, and implementation of management practices also were examined to determine the major factors affecting the trends.

From 1993 to 2003, widespread downward trends in streamflow indicated that drought conditions from about 2000 to 2003 led to decreasing streamflow throughout much of the Missouri River Basin. Flow-adjusted trends in nitrite plus nitrate and ammonia concentrations were split nearly equally between nonsignificant and downward; at about one-half of the sites, management practices likely were contributing to measurable decreases in concentrations of nitrite plus nitrate and ammonia. Management practices had less of an effect on concentrations of total nitrogen; downward flow-adjusted trends in total nitrogen concentrations occurred at only 2 of 19 sites. The pattern of non-flow-adjusted trends in nitrite plus nitrate concentrations was similar to the pattern of flowadjusted trends; non-flow-adjusted trends were split nearly equally between nonsignificant and downward. A substantial source of nitrite plus nitrate to these streams likely was ground water; because of the time required for ground water to travel to streams, there may have been a lag time between the implementation of some pollution-control strategies and improvement in stream quality, contributing to the nonsignificant trends in nitrite plus nitrate. There were more sites with downward non-flow-adjusted trends than flow-adjusted trends in both ammonia and total nitrogen concentrations, possibly a result of decreased surface runoff from nonpoint sources associated with the downward trends in streamflow. No strong relations between any of the nitrogen trends and changes in nutrient sources or landscape characteristics were identified.

Although there were very few upward trends in nitrogen from 1993 to 2003, there were upward flow-adjusted trends in total phosphorus concentrations at nearly one-half of the sites. At these sites, not only were pollution-control strategies not contributing to measurable decreases in total phosphorus concentrations, there was likely an increase in phosphorus loading on the land surface. There were fewer upward nonflow-adjusted than flow-adjusted trends in total phosphorus concentrations; at the majority of sites, overall total phosphorus concentrations did not change significantly during this period. The preponderance of upward flow-adjusted trends and nonsignificant non-flow-adjusted trends indicates that in some areas of the Missouri River Basin, overall concentrations of total phosphorus would have been higher without the decrease in streamflow and the associated decrease in surface runoff during the study period. During the study period, phosphorus loads from fertilizer generally increased at over one-half of the sites in the basin. Upward flow-adjusted trends were related to increasing fertilizer use in the upstream drainage area, particularly in the 10 percent of the drainage area closest to the monitoring site. This relation was not seen with the non-flow-adjusted trends in total phosphorus concentrations, indicating that decreasing streamflow and associated decreasing surface runoff in the basin during the study period may have offset the effects of increasing fertilizer use.

There were fewer sites with upward trends in suspended sediment than in total phosphorus. Although phosphorus can be transported by sorption to particulate material, the different trend patterns of the two constituents indicate that changes in suspended-sediment concentrations were not contributing to a concomitant change in total phosphorus concentrations in the Missouri River Basin. At some sites, pollution-control strategies or other human activities were contributing to a measurable decrease in suspended-sediment concentrations, but at the majority of sites, there were no measurable effects from pollution-control strategies. Spatial differences in 
stream density and overbank storage may have contributed to the spatial variability in flow-adjusted trends in suspendedsediment concentrations throughout the basin. Sediment loading probably was less affected by overbank storage at sites with higher stream densities, and consequently, pollutioncontrol strategies may have contributed to measurable decreases in suspended-sediment concentrations at these sites. In contrast, at low stream-density sites where overbank storage was occurring, pollution-control strategies may not have contributed to measurable changes in suspendedsediment concentrations because the sediment loading prior to BMP implementation would have already been attenuated by overbank storage. There were more downward nonflow-adjusted trends than downward flow-adjusted trends in suspended-sediment concentrations, indicating that naturally decreasing streamflow over the study period was as or more influential in decreasing the concentrations of suspended sediment than were pollution-control strategies or other human activities. If streamflow had not decreased during the study period, it is unlikely that overall concentrations of suspended sediment would have decreased at many sites.

The streamflow and flow-adjusted trends in concentration for the period from 1993 to 2003 were placed in a longer context by comparing them to longer term, non-monotonic trends for the period from 1985 to 2003 at a subset of the sites. From 1985 to 2003, streamflow generally decreased from about 1985 to 1991, increased from about 1992 to 1996, and decreased from about 1997 to 2003. During the same period, many flow-adjusted trends in total nitrogen, nitrite plus nitrate, total phosphorus, orthophosphorus, and suspended-sediment concentrations occurred between 1985 and 1991 and between 1997 and 2003; unlike with streamflow, the direction of the flow-adjusted trends varied among sites and among time periods. These longer term, non-monotonic patterns indicated that consistent monotonic changes in streamflow and concentration may not have occurred through the entire period from 1993 to 2003 , as indicated by the shorter term trend analysis.

The longer term patterns in streamflow also indicated that the decreasing steamflows observed from 1993 to 2003 in the Missouri River Basin likely will not continue indefinitely. In some parts of the basin, nutrient and suspended-sediment concentrations may have been higher without the decrease in streamflow and the associated decrease in surface runoff that occurred during the study period. Without additional steps to minimize surface runoff or nutrient loading on the land, it is possible that concentrations will increase when streamflow and runoff begin to increase once again. In addition, results from three case studies indicated that a substantial portion of the total flow and nitrate load in streams may consist of ground-water inflow in some parts of the basin. In these areas, nutrient loading to streams may be addressed by management practices focused not only on reducing surface runoff but also on maintaining and (or) improving ground-water quality.

\section{Introduction}

The Missouri River Basin drains about 1,371,000 km², one-sixth of the conterminous United States, and is located in parts of 10 States and Canada (fig. 1). The Missouri River flows 3,767 km from its headwaters in the Rocky Mountains through the Great Plains to its confluence with the Mississippi River near St. Louis, Missouri. About 11 million people currently (2006) live in the Missouri River Basin; the population increased by more than 1.3 million people from 1990 through 2000 (U.S. Census Bureau, 1991, 2000). Land use in the northwestern one-half of the basin primarily is rangeland and shrubland, whereas land use in the southeastern one-half of the basin primarily is pasture and row crops (fig. $2 A$ ). Urban areas comprise only a small part of the basin and are concentrated near large cities like Denver, Colorado; Omaha, Nebraska; and Kansas City, Missouri.

The historically diverse riverine and flood-plain habitats of the Missouri River and its tributaries, including braided channels, backwater sloughs, and sandbars, have been altered substantially over the last 150 years through channelization and dam construction. Numerous dams have been constructed for flood control, navigation, hydroelectric power generation, and water storage for irrigation and municipal water supply on the upper Missouri River main stem and on the major tributary basins of the Yellowstone, Platte, Kansas, and Osage Rivers. A series of six reservoirs on the main stem in Montana, North Dakota, South Dakota, and Nebraska is the largest reservoir system in North America, with a storage capacity of $9.1 \times 10^{10} \mathrm{~m}^{3}$ (73.4 million acre-ft) (Roth, 2005). In addition, the lower $1,180 \mathrm{~km}$ of the main stem were channelized or stabilized in the $20^{\text {th }}$ century to improve navigation (Lower Missouri River Ecosystem Initiative, 1998). Prior to dam construction and channelization, the Missouri River had an annual period of high streamflow during the spring and summer due to mountain snowmelt and rain, and the river carried a high sediment load. The high spring and summer streamflow pulse triggered spawning in native river fish, promoted productivity in the upper river reaches, and inundated backwaters and wetlands, providing seasonal nursery and feeding areas for fish and migratory birds (Lower Missouri River Ecosystem Initiative, 1998). The sediment scouring and deposition continually reshaped the channel and the flood plain, maintaining the diverse riverine habitat (Crane, 2005). Currently, streamflow throughout the year is highly regulated, and sediment loads are greatly reduced compared to pre-dam conditions due to the trapping of sediment behind the dams.

The basin covers seven major physiographic provinces - the steep mountains, high plateaus, and intervening valleys of the Northern, Southern, and Middle Rocky Mountain Provinces and the Wyoming Basin Province; the semiarid elevated tablelands and smooth grasslands of the Great Plains Province; 


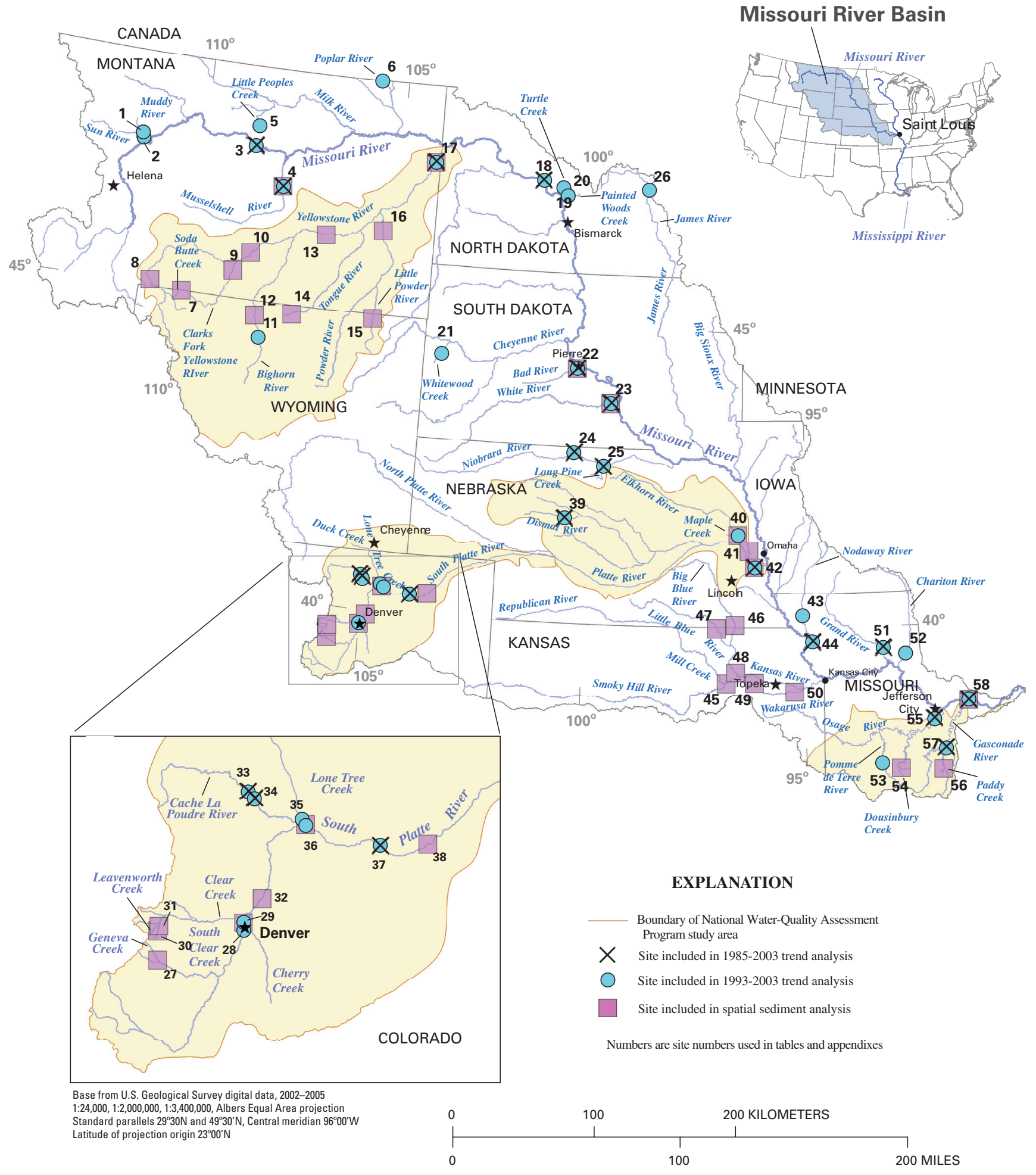

Figure 1. Location of National-Water Quality Assessment Program study areas within the Missouri River Basin and sites included in trend analysis. 


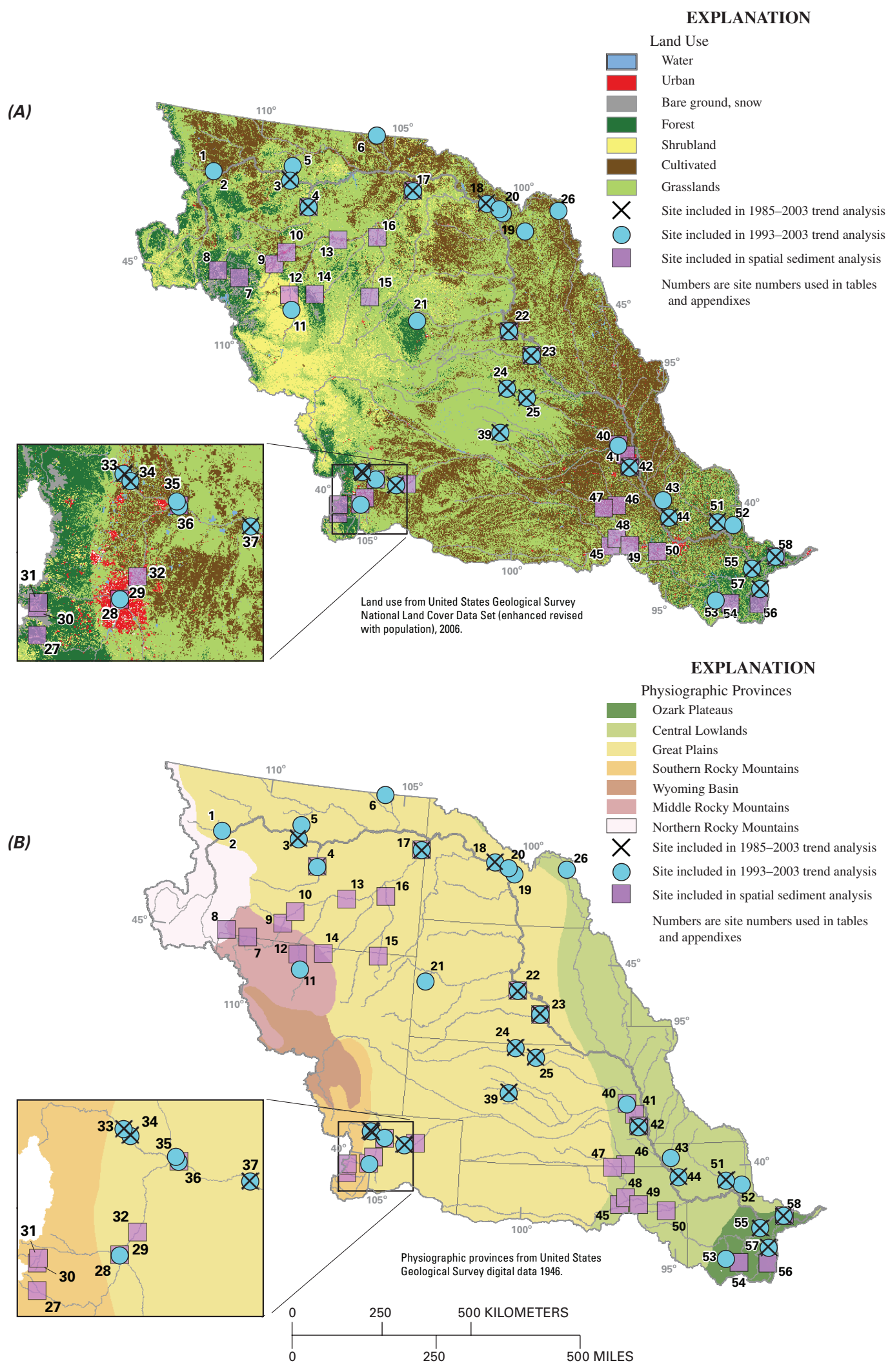

Figure 2. Distribution of land use and physiographic provinces in the Missouri River Basin. 
the gently rolling hills and intermittent escarpments of the Central Lowlands Province; and the deep stream valleys and intervening ridges in the Ozark Plateaus province (Fenneman and Johnson, 1946) (fig. 2B). Climate in the basin varies due to topography and geography; climatic conditions range from cold and moist in the Rocky Mountains to semiarid in the Great Plains to humid continental in the Central Lowlands. Throughout the basin, most precipitation occurs as rain during the spring and summer, although significant snowfall can occur in the Rocky Mountains during the winter. Mean annual precipitation ranges from about 50 to $100 \mathrm{~cm}$ in the Rocky Mountains, from about 25 to $50 \mathrm{~cm}$ in the Great Plains, and from about 100 to $130 \mathrm{~cm}$ in the Central Lowlands (Huntzinger and Ellis, 1993; Adamski and others, 1995; Litke and Kimbrough, 1998; and Zelt and others, 1999).

In 1987, the U.S. Geological Survey (USGS) began a study of more than 50 major river basins and aquifers across the Nation as part of the National Water-Quality Assessment (NAWQA) Program. One of the major goals of the NAWQA Program is to determine how water-quality conditions change over time. Within the Missouri River Basin, the NAWQA Program has collected long-term water-quality data in the Yellowstone River Basin in Wyoming, Montana, and North Dakota; the South Platte River Basin in Colorado, Wyoming, and Nebraska; the Platte River Basin in Nebraska; and the Ozark Plateaus in Kansas and Missouri. Outside of the NAWQA Program, the USGS has collected additional long-term data throughout the Missouri River Basin in cooperation with other Federal, State, and local agencies. Collectively, these data can provide insight into how water-quality conditions have changed over time in the Missouri River and its tributaries and how natural features and human activities have contributed to those changes.

\section{Purpose and Scope}

This report describes the methods and results of a study of nutrient and suspended-sediment trends in the Missouri River Basin. Trends in nutrients and suspended-sediment concentrations at selected stream sites in the Missouri River Basin are determined and factors affecting those trends are described. Trends were calculated for total nitrogen (TN), total phosphorus (TP), orthophosphorus (OP), nitrite plus nitrate (NOX), ammonia (NH3), and suspended sediment (SS) for the period from 1993 to 2003. Flow-adjusted and nonflow-adjusted trends in concentrations were determined, and relations between those trends and changes in nutrient sources, streamflow, and implementation of management practices were examined.

In addition, in order to place the flow-adjusted trends in concentration from 1993 to 2003 in a longer term context, they are compared to longer term flow-adjusted trends from 1985 to 2003 at a subset of the sites. The effect of ground water on surface-water NOX trends are examined, spatial differences in
SS yields are compared, and the scale-dependency of the relation between trends and the factors affecting those trends from 1993 to 2003 are examined.

Trends in streamflow are presented first in this report, followed by trends in nitrogen (TN, NOX, and NH3), phosphorus (TP and OP), and SS concentrations. For each nutrient and suspended-sediment constituent, flow-adjusted and non-flowadjusted trends in concentration from 1993 to 2003 are discussed, and both trends are compared to changes in nutrients sources and (or) landscape characteristics at different scales. The flow-adjusted trends in concentration from 1993 to 2003 then are compared to the flow-adjusted trends in concentration from 1985 to 2003 .

\section{Acknowledgments}

The authors wish to thank the following USGS personnel: Dave Mueller, Dave Lorenz, and Charlie Crawford for their technical input on trend analysis methodology and Greg Schwarz for running the non-flow-adjusted trend analyses. They also would like to acknowledge Jodi Norris, Kip Bossong, Naomi Nakagaki, JoAnn Gronberg, James Falcone, Brian Fredrick, Amy Zoller, and Julie Godberson for their extensive contributions to the ancillary data compilation and Jean Dupree for her assistance in preparing the illustrations. Skip Vecchia and Norm Spahr provided helpful technical reviews.

\section{Approach}

The approach for calculating loads and trends and the associated tools and data sets used in interpretation are presented in this section.

\section{Trends from 1993 to 2003}

\section{Site Selection}

The initial pool of potential sites included all sites in the Missouri River Basin with data publicly accessible during January 2005 through the online USGS National Water Information System (NWIS) database at http://waterdata.usgs. gov/usa/nwis/qw. Sites were selected for analysis of trends between water year (October 1 through September 30) 1993 and water year 2003 on the basis of the following minimum criteria:

- period of water-quality record with a beginning year of 1993 or earlier and an ending year of 2003 or later;

- approximately quarterly sampling each year; 
- continuous daily mean discharge between 1993 and 2003 at that site or a nearby representative site;

- data gaps no longer than 2 years and only during the middle 6 years of record;

- representative coverage of samples over the hydrograph to avoid bias toward

low or high streamflows;

- representative coverage over all seasons to avoid bias towards certain times of year.

Additional sites were included for step-trend analysis on the basis of the following minimum criteria:

- 3 years of sampling at the beginning and end of the period (1993-95 and 2001-03);

- approximately quarterly sampling during 1993-95 and 2001-03;

- continuous daily mean discharge during 1993-95 and 2001-03 at that site or a nearby representative site;

- representative coverage of samples over the hydrograph to avoid bias toward low or high streamflows;

- representative coverage over all seasons to avoid bias towards certain times of year.

Sites were screened separately for TN, TP, OP, NOX, $\mathrm{NH} 3$, and SS. To maximize data coverage, total (unfiltered) OP, total NOX, and total NH3 were combined with their dissolved (filtered) counterparts. Previous comparison of paired dissolved and total samples at the USGS National Water-Quality Laboratory (NWQL) in Lakewood, Colorado, found that analytical values for unfiltered and filtered concentrations were statistically indistinguishable (U.S. Geological Survey, 1992). When a direct measurement of TN was unavailable, it was calculated from the sum of Kjeldahl nitrogen $(\mathrm{KN})$ and NOX. For KN, total KN was used preferentially; dissolved KN was used only when total $\mathrm{KN}$ was unavailable. If a direct measurement of either dissolved or total NOX was not available, it was calculated as the sum of total or dissolved nitrite (NO2) and total or dissolved nitrate (NO3) as follows:

- if NO2 and NO3 were censored, NOX was censored to the maximum of the two censoring levels;

- if $\mathrm{NO} 2$ was not censored and $\mathrm{NO} 3$ was censored, NOX was set equal to $\mathrm{NO}$;

- if $\mathrm{NO} 2$ was censored and $\mathrm{NO} 3$ was not censored, NOX was set equal to NO3;

- if both $\mathrm{NO} 2$ and $\mathrm{NO} 3$ were not censored, NOX was set equal to the sum of $\mathrm{NO} 2$ and $\mathrm{NO} 3$.

TN then was calculated as follows:

- if neither KN nor NOX were measured and NOX could not be calculated, TN was not calculated;
- if $\mathrm{KN}$ and NOX were censored, TN was censored to the maximum of the two censoring levels;

- if $\mathrm{KN}$ was not censored and NOX was censored, TN was set equal to $\mathrm{KN}$;

- if $\mathrm{KN}$ was censored and NOX was not censored, TN was set equal to NOX;

- if KN and NOX were not censored, TN was set equal to the sum of $\mathrm{KN}$ and NOX;

Final sites are listed in table 1, along with a list of constituents used in trend analyses for each site.

Once the data sets for the final sites were compiled, censoring-level adjustments were necessary prior to data analysis. Before the late 1990s, the NWQL censored data at the method detection limit (MDL), where the risk of a false positive detection is no more than 1 percent (Oblinger Childress and others, 1999). However, the risk of a false negative at the MDL is as much as 50 percent. As a result, the NWQL began to censor data at the laboratory reporting level (LRL), a value generally twice the MDL; this practice was implemented in 1999 for KN, in 2000 for TP, and in 2001 for NH3, NOX, and OP. Values measured less than the MDL are reported as less than the LRL, and values measured between the MDL and LRL are reported as estimated concentrations with an "E" remark code. This practice can result in upward bias during statistical analysis of censored data (as used in this study) because the probability that an observation might fall between the MDL and LRL likely is overstated (Helsel, 2005). The possibility of a few false negatives occurring is less of a concern than the problems caused by such a bias (Mueller and Spahr, 2005). As a result, all data were recensored from the LRL to the associated MDL reported by the NWQL for a given constituent during a given time period. When no documentation of an associated MDL could be found, values were left censored at the LRL. All data from NWIS were assumed to have been analyzed at the NWQL; this could not always be verified and may have resulted in a small number of samples being recensored unnecessarily. A small number of samples also had been diluted, and the resulting LRL values had been multiplied by the dilution factor; for these samples, values were recensored to the MDL multiplied by the dilution factor. Values with an "E" remark code were left unchanged. Additionally, NH3 values originally reported as less than $0.01,0.01$, and less than $0.015 \mathrm{mg} / \mathrm{L}$ prior to September 30, 1997, were recensored to less than $0.02 \mathrm{mg} / \mathrm{L}$ on the basis of guidance from the NWQL (U.S. Geological Survey, 1997). Once recensoring was complete, NOX and TN values were recalculated for the final sites on the basis of the new censoring levels.

Finally, the corresponding daily mean streamflow value for each discrete water-quality sample was obtained from the NWIS database. At site 55, the streamflow record only extended back through water year 1997; streamflow values for earlier dates were obtained from the nearest upstream location (USGS station 06926500). No streamflow data were available for site 57 . The nearest streamgage to site 57 was down- 
Table 1. Basin characteristics and trend coverage of study sites in the Missouri River Basin, 1993-2003.

[USGS, U.S. Geological Survey; TN, total nitrogen; NOX, nitrite plus nitrate; NH3, ammonia; TP, total phosphorus; OP, orthophosphorus; SS, suspended sediment; +, constituent was included only in the 1993-2003 trend analysis; X, constituent was included in both the 1985-2003 and 1993-2003 trend analysis; SP, site was included in the spatial sediment analysis; --, no trend analysis]

\begin{tabular}{|c|c|c|c|c|c|c|c|c|c|c|}
\hline \multirow{2}{*}{$\begin{array}{c}\text { Site } \\
\text { number } \\
\text { (fig. 1) }\end{array}$} & \multirow{2}{*}{$\begin{array}{l}\text { USGS } \\
\text { station } \\
\text { number }\end{array}$} & \multirow[b]{2}{*}{ USGS station name } & \multirow{2}{*}{$\begin{array}{c}\text { Drainage } \\
\text { area, } \\
\text { in square } \\
\text { kilometers }\end{array}$} & \multirow{2}{*}{$\begin{array}{l}\text { Spatial } \\
\text { sedi- } \\
\text { ment } \\
\text { trend }\end{array}$} & \multicolumn{6}{|c|}{ Temporal trend type } \\
\hline & & & & & TN & NOX & NH3 & TP & OP & SS \\
\hline 1 & 06088500 & Muddy Creek at Vaughn, MT & 662 & -- & -- & + & + & -- & + & + \\
\hline 2 & 06089000 & Sun River near Vaughn, MT & 4,586 & -- & -- & + & + & + & + & + \\
\hline 3 & 06115200 & Missouri River near Landusky, MT & 105,300 & -- & -- & -- & -- & -- & -- & $\mathrm{X}$ \\
\hline 4 & 06130500 & Musselshell River at Mosby, MT & 20,300 & $\mathrm{SP}$ & -- & -- & -- & -- & -- & $\mathrm{X}$ \\
\hline 5 & 06154410 & Little Peoples Creek near Hays, MT & 34 & -- & -- & + & + & -- & + & + \\
\hline 6 & 06178000 & Poplar River at International Boundary, MT & 929 & -- & + & + & -- & + & + & + \\
\hline 7 & 06187915 & Soda Butte Creek at Park Boundary at Silver Gate, MT & 81 & SP & -- & -- & -- & -- & -- & -- \\
\hline 8 & 06191500 & Yellowstone River at Corwin Springs, MT & 6,783 & SP & -- & -- & -- & -- & -- & -- \\
\hline 9 & 06208500 & Clarks Fork Yellowstone River at Edgar, MT & 5,237 & SP & -- & -- & -- & -- & -- & -- \\
\hline 10 & 06214500 & Yellowstone River at Billings, MT & 30,580 & SP & -- & -- & -- & -- & -- & -- \\
\hline 11 & 06274300 & Bighorn River at Basin, WY & 34,250 & -- & -- & + & + & -- & + & -- \\
\hline 12 & 06279500 & Bighorn River at Kane, WY & 40,820 & SP & -- & -- & -- & -- & -- & -- \\
\hline 13 & 06295000 & Yellowstone River at Forsyth, MT & 104,000 & SP & -- & -- & -- & -- & -- & -- \\
\hline 14 & 06298000 & Tongue River near Dayton, WY & 534 & SP & -- & -- & -- & -- & -- & -- \\
\hline 15 & 06324970 & Little Powder River above Dry Creek, near Weston, WY & 3,204 & $\mathrm{SP}$ & -- & -- & -- & -- & -- & -- \\
\hline 16 & 06326500 & Powder River near Locate, MT & 33,850 & SP & -- & -- & -- & -- & -- & -- \\
\hline 17 & 06329500 & Yellowstone River near Sidney, MT & 177,100 & $\mathrm{SP}$ & $\mathrm{X}$ & + & + & + & + & $\mathrm{X}$ \\
\hline 18 & 06338490 & Missouri River at Garrison Dam, ND & 468,800 & -- & $\mathrm{X}$ & + & + & + & + & -- \\
\hline 19 & 06341410 & Turtle Creek above Washburn, ND & 1,400 & -- & -- & + & + & -- & + & -- \\
\hline 20 & 06341800 & Painted Woods Creek near Wilton, ND & 1,231 & -- & -- & + & + & -- & + & -- \\
\hline 21 & 06436180 & Whitewood Creek above Whitewood, SD & 147 & -- & -- & -- & -- & -- & -- & + \\
\hline 22 & 06441500 & Bad River near Fort Pierre, SD & 8,150 & SP & -- & -- & -- & -- & -- & $\mathrm{X}$ \\
\hline 23 & 06452000 & White River near Oacoma, SD & 25,800 & SP & -- & -- & -- & -- & -- & $\mathrm{X}$ \\
\hline 24 & 06461500 & Niobrara River near Sparks, NE & 21,670 & -- & + & + & + & $\mathrm{X}$ & + & -- \\
\hline 25 & 06463500 & Long Pine Creek near Riverview, NE & 1,174 & -- & + & $\mathrm{X}$ & + & $\mathrm{X}$ & + & -- \\
\hline 26 & 06468250 & James River above Arrowwood Lake near Kensal, ND & 3,019 & -- & + & + & + & -- & + & + \\
\hline 27 & 06705500 & Geneva Creek at Grant, CO & 193 & SP & -- & -- & -- & -- & -- & -- \\
\hline 28 & 06713500 & Cherry Creek at Denver, CO & 1,063 & -- & + & + & + & + & + & + \\
\hline 29 & 06714000 & South Platte River at Denver, CO & 10,010 & $\mathrm{SP}$ & + & + & + & + & + & -- \\
\hline 30 & 06714400 & South Clear Creek above Lower Cabin Creek Reservoir, CO & 31 & SP & -- & -- & -- & -- & -- & -- \\
\hline 31 & 06714800 & Leavenworth Creek at mouth near Georgetown, $\mathrm{CO}$ & 31 & SP & -- & -- & -- & -- & -- & -- \\
\hline 32 & 06720500 & South Platte River at Henderson, CO & 12,350 & SP & -- & -- & -- & -- & -- & -- \\
\hline 33 & 06752260 & Cache la Poudre River at Fort Collins, CO & 2,921 & -- & -- & $\mathrm{X}$ & + & -- & + & -- \\
\hline
\end{tabular}


Table 1. Basin characteristics and trend coverage of study sites in the Missouri River Basin, 1993-2003. —Continued

[USGS, U.S. Geological Survey; TN, total nitrogen; NOX, nitrite plus nitrate; NH3, ammonia; TP, total phosphorus; OP, orthophosphorus; SS, suspended sediment; +, constituent was included only in the 1993-2003 trend analysis; X, constituent was included in both the 1985-2003 and 1993-2003 trend analysis; SP, site was included in the spatial sediment analysis; --, no trend analysis]

\begin{tabular}{|c|c|c|c|c|c|c|c|c|c|c|}
\hline \multirow{2}{*}{$\begin{array}{c}\text { Site } \\
\text { number } \\
\text { (fig. 1) }\end{array}$} & \multirow[b]{2}{*}{$\begin{array}{l}\text { USGS station } \\
\text { number }\end{array}$} & \multirow[b]{2}{*}{ USGS station name } & \multirow{2}{*}{$\begin{array}{c}\text { Drainage } \\
\text { area, } \\
\text { in square } \\
\text { kilometers }\end{array}$} & \multirow{2}{*}{$\begin{array}{c}\text { Spatial } \\
\text { sedi- } \\
\text { ment } \\
\text { trend }\end{array}$} & \multicolumn{6}{|c|}{ Temporal trend type } \\
\hline & & & & & TN & NOX & NH3 & TP & $\mathbf{O P}$ & SS \\
\hline 34 & 06752280 & Cache la Poudre River above Boxelder Creek, near Timnath, CO & 3,223 & -- & -- & $\mathrm{X}$ & + & -- & + & -- \\
\hline 35 & 06753990 & Lonetree Creek near Greeley, CO & 1,478 & -- & + & + & + & + & + & + \\
\hline 36 & 06754000 & South Platte River near Kersey, CO & 25,020 & SP & + & + & + & + & + & + \\
\hline 37 & 06758500 & South Platte River near Weldona, CO & 34,160 & -- & + & $\mathrm{X}$ & + & + & + & -- \\
\hline 38 & 06759910 & South Platte River at Cooper Bridge, near Balzac, CO & 43,050 & SP & -- & -- & -- & -- & -- & -- \\
\hline 39 & 06775900 & Dismal River near Thedford, NE & 2,503 & -- & $\mathrm{X}$ & $\mathrm{X}$ & + & $\mathrm{X}$ & $\mathrm{X}$ & + \\
\hline 40 & 06800000 & Maple Creek near Nickerson, NE & 954 & SP & + & + & + & + & + & + \\
\hline 41 & 06800500 & Elkhorn River at Waterloo, NE & 17,870 & SP & -- & -- & -- & -- & -- & -- \\
\hline 42 & 06805500 & Platte River at Louisville, NE & 220,900 & SP & $X$ & + & + & $\mathrm{X}$ & $\mathrm{X}$ & $X$ \\
\hline 43 & 06817700 & Nodaway River near Graham, MO & 3,927 & -- & + & + & + & + & + & -- \\
\hline 44 & 06818000 & Missouri River at St. Joseph, MO & $1,081,000$ & -- & $\mathrm{X}$ & + & + & $\mathrm{X}$ & $\mathrm{X}$ & -- \\
\hline 45 & 06879100 & Kansas River at Fort Riley, KS & 116,200 & SP & -- & -- & -- & -- & -- & -- \\
\hline 46 & 06882000 & Big Blue River at Barneston, NE & 11,520 & SP & -- & -- & -- & -- & -- & -- \\
\hline 47 & 06884025 & Little Blue River at Hollenberg, KS & 7,128 & SP & -- & -- & -- & -- & -- & -- \\
\hline 48 & 06887000 & Big Blue River near Manhattan, KS & 24,970 & SP & -- & -- & -- & -- & -- & -- \\
\hline 49 & 06888500 & Mill Creek near Paxico, KS & 818 & SP & -- & -- & -- & -- & -- & -- \\
\hline 50 & 06891500 & Wakarusa River near Lawrence, KS & 1,101 & SP & -- & -- & -- & -- & -- & -- \\
\hline 51 & 06902000 & Grand River near Sumner, MO & 17,950 & -- & $\mathrm{X}$ & + & + & $\mathrm{X}$ & + & -- \\
\hline 52 & 06905500 & Chariton River near Prairie Hill, MO & 4,897 & -- & + & + & + & + & + & -- \\
\hline 53 & 06921070 & Pomme De Terre River near Polk, MO & 713 & -- & + & + & + & + & + & -- \\
\hline 54 & 06923150 & Dousinbury Creek at Highway JJ near Wall Street, MO & 106.0 & SP & -- & -- & -- & -- & -- & -- \\
\hline 55 & 06926510 & Osage River below St. Thomas, MO & 37,910 & -- & $\mathrm{X}$ & + & + & + & + & -- \\
\hline 56 & 06929315 & Paddy Creek above Slabtown Spring, MO & 88.55 & SP & -- & -- & -- & -- & -- & -- \\
\hline 57 & 06930800 & Gasconade River above Jerome, MO & 6,649 & -- & $\mathrm{X}$ & + & + & + & + & -- \\
\hline 58 & 06934500 & Missouri River at Hermann, MO & $1,345,000$ & SP & $\mathrm{X}$ & + & + & $\mathrm{X}$ & $\mathrm{X}$ & $\mathrm{X}$ \\
\hline
\end{tabular}


stream at the Gasconade River at Jerome, MO (USGS station 06933500); between the two locations, Little Piney Creek enters the Gasconade River. The contribution of Little Piney Creek to streamflow in the Gasconade River was determined by measuring streamflow near the mouth of Little Piney Creek and upstream at the streamgage at Little Piney Creek at Newburg, MO (USGS station 06932000); streamflow increased 1.5 times between these two locations. Therefore, streamflow at USGS station 06932000 was multiplied by 1.5 and subtracted from streamflow at USGS station 06933500 to estimate streamflow at site 57 .

\section{Trend Analysis}

Trends in nutrient and SS concentrations can be affected both by natural processes, such as changes in surface runoff and streamflow, and by human activities, such as the implementation of pollution-control strategies. Pollution-control strategies are designed to decrease nutrient and SS concentrations reaching streams, but in some situations, their effects can be offset by natural changes in streamflow. For example, if nonpoint sources are the predominant source of nutrients to a stream, a decrease in concentration resulting from the implementation of best management practices (BMPs) may be offset by an increase in concentration resulting from natural increases in surface runoff and streamflow. If point sources are the predominant source of nutrients to a stream, a decrease in concentration resulting from treatment upgrades may be offset by the decreased in-stream dilution capacity resulting from a natural decrease in streamflow. In both of these examples, although changing climate and streamflow conditions may be counteracting the effects of pollution-control strategies, the strategies are still having a positive effect; in-stream concentrations would have been even higher in the absence of BMP implementation or treatment upgrades.

Because of the often counteracting effects of natural and human factors on water-quality conditions, it is important to consider two types of trends in concentration - (1) non-flowadjusted trends, the overall trends resulting from both natural and human factors, and (2) flow-adjusted trends, the trends that would have occurred in the absence of natural streamflow variability. In the analysis of flow-adjusted (FA) trends, the removal of streamflow as a variable affecting concentration allows trends caused by other factors to be identified and the effects of pollution-control strategies to be more directly assessed. In the analysis of non-flow-adjusted (NFA) trends, the inclusion of any and all factors affecting concentration allows trends affecting aquatic ecosystems and the status of streams relative to water-quality standards to be assessed. Both NFA and FA trends are presented in this report. Because the interpretation of the two trends can be improved by understanding how streamflow has changed during the same period, trends in streamflow also are presented herein.

Concentration trends are reported in percentage change per year; streamflow trends are reported in cubic meters per second per year. Ambient concentrations and streamflow vary throughout the Missouri River Basin, and a given percentage increase or decrease may be more notable in one stream location than another. For example, a 100-percent increase in NOX concentrations in a stream with an ambient concentration of $0.001 \mathrm{mg} / \mathrm{L}$ likely will have less of an environmental impact than a 100-percent increase in a stream with an ambient concentration of $5 \mathrm{mg} / \mathrm{L}$. As a result, reference concentrations and streamflows describing the central tendency in the concentration and streamflow data at each site are presented with the trend results. The same reference concentration is presented with both the NFA and FA trends because flow-adjusted concentrations are a mathematical construct used only for trend analysis. These reference concentrations and streamflows are not intended to provide a "starting" or "ending" concentration or streamflow, only a context for evaluating the potential importance of a given change over time.

\section{Flow-Adjusted Trends in Concentration}

Monotonic FA trends in concentration were estimated with parametric multiple-regression analysis by use of the statistical program LOADEST (Runkel and others, 2004) in S-plus version 6.1, release 1 (Insightful Corporation, 2002). The dependent variable was concentration, and the independent variables were various functions of streamflow, decimal time, and season. The trend was determined using the model coefficient of the decimal time term; a coefficient significantly different from zero indicated the presence of a significant trend.

Difficulties with multiple regression can occur in the presence of multicollinearity and censoring. Multicollinearity, which occurs when one or more independent variables are highly correlated and can lead to misspecified model coefficients (Brown, 1998), was eliminated if necessary by centering the independent variables (Runkel and others, 2004). To account for the presence of censored data, adjusted maximum-likelihood estimation was used to calculate model coefficients. The adjusted maximum-likelihood estimation procedure assumes censored and uncensored data follow a specific distribution when determining regression coefficients. The adjusted maximum-likelihood estimation procedure also corrects for first-order bias in the standard maximumlikelihood regression coefficients and incorporates a factor that minimizes the bias that can occur when estimated logarithms of concentration are retransformed to original units (Cohn, 1988; Cohn and others, 1992).

The first step for each constituent at each site was to automatically select within LOADEST the best model from all possible combinations of natural logarithm $(\log )$ of streamflow, log of flow squared, decimal time, decimal time squared, sine of time, and cosine of time using the Akaike information criterion (AIC) (Akaike, 1981). Step trends were evaluated with an additional binary variable designating samples as residing in either the "early" or the "late" period. Residuals from the automatically selected best-fit model were examined for homoscedasticity and normality, two fundamental assump- 
tions of linear models; if either assumption was violated, the model was rejected. In those cases, the second step was to evaluate models with additional combinations of the previously mentioned independent variables in order of their AIC rank. If these models did not meet the linearity assumptions, the third step was to explore additional user-specified models. Additional independent variables available for consideration in user-specified models were reciprocal transform of streamflow, reciprocal transform of streamflow squared, one or two breakpoints in streamflow (either log or reciprocal transform), and seasonal periods that could encompass any combination of months; these could be used in combination with the terms used during the automatic selection procedure. Residuals from the resulting user-defined models were examined for homoscedasticity and normality, and the optimal model was selected. If all three steps failed to produce valid models, that constituent at that site was excluded from further analysis.

The final model always included, at a minimum, log of streamflow (to ensure that the resulting time trend was flow adjusted) and decimal time (to ensure that a trend over time could be calculated). In addition, sine of time and cosine of time always were present together if either were selected.

The FA trend in concentration was expressed as the average percentage change per year, calculated as follows:

$$
\frac{\% \Delta F A C}{y r}=100 \times\left(e^{2 \beta_{D T}\left(T_{m}-T_{a}\right)+\beta_{T}}\right)-1,
$$

where

$$
\begin{aligned}
& \frac{\% \triangle F A C}{y r} \text { is the FA trend in concentration, expressed } \\
& \mathrm{e} \text { as the average percentage change per year; } \\
& \beta_{D T} \text { is the coefficient of the decimal time squared term; } \\
& T_{m} \text { is the decimal time at the midpoint of the period } \\
& \quad \text { of record; } \\
& T_{a} \quad \text { is the decimal time centered so that the linear and } \\
& \beta_{T} \quad \text { is the coefficient of the decimal time term. }
\end{aligned}
$$

If the decimal time squared term did not appear in the final optimal model, $\beta_{\mathrm{DT}}$ was set equal to zero. The 95-percent confidence interval of each trend was calculated by use of the standard deviations of $\beta_{\mathrm{DT}}$ and $\beta_{\mathrm{T}}$. Trend results were considered significant if the $\mathrm{p}$-value for the decimal time term was less than or equal to 0.05 .

Reference concentrations were calculated using $\mathrm{T}_{\mathrm{a}}$ as the time term and the median daily streamflow for the period of record as the discharge term in the final model. These concentrations are presented in this report together with the FA and NFA trends in concentration.

\section{Non-Flow-Adjusted Trends in Concentration}

Many of the nutrient and SS data sets were inappropriate for analysis of NFA trends in concentration. Some of these data were collected using sampling designs that changed during the period of record. For example, at some sites a greater proportion of high streamflows were sampled in the first one-half of the period than in the second one-half, possibly because of changes in funding or in the objectives of a study. At other sites, fixed-interval sampling was conducted quarterly on a consistent basis throughout the period of record, but a representative number of higher flow samples were not collected equitably each year. Data sets such as these can contain long-term variations in concentration that are an artifact of the sampling design and do not reflect a true long-term trend. To deal with these limitations in the determination of NFA trends in concentration, a coupled statistical modeling approach that simultaneously accounted for changes in streamflow and concentration was used.

Monotonic NFA trends in concentration were derived from parameter estimates and associated covariances obtained from a model of streamflow and the final optimal water-quality model from the analysis of FA trends in concentration, with both models being estimated in natural logarithm space. The model of streamflow consisted of an intercept, decimal time, sine and cosine of time, and a serially correlated error term; the streamflow residual was assumed to follow an autoregressive process of order 20 [AR(20)] (Fuller, 1996). The streamflow model was estimated using maximum-likelihood estimation methods as used by the AUTOREG procedure in SAS 9, version 1, release 2 (SAS Institute Inc., 2004). For some sites, serial correlation in the residuals was not fully removed by the AR(20) model. Significant residual serial correlation could invalidate the standard error of the streamflow trend coefficient, although the practical importance of this effect for the statistical significance of the NFA trend was likely to be small (Greg Schwarz, U.S. Geological Survey, written commun., 2006).

The water-quality model related the logarithm of nutrient and SS concentrations to various functions of streamflow, decimal time, and season as described previously. An abstract representation of the model is given by:

$$
c_{t}=b_{0}+m\left(q_{t}\right) b_{q}+h\left(T_{t}\right) b_{T}+x_{t} b_{x}+e_{t},
$$

where

$c_{t}$ is the natural logarithm of constituent concentration in period $t$;

$b_{0}$ is the intercept;

$m(\cdot)$ and $h(\cdot)$ are multi-element vector functions of $q$ and $T$

$q_{t}$ is natural logarithm of streamflow;

$b_{q}, b_{T}$ and $b_{x}$ are vector-valued coefficients to be estimated;

$T_{t}$ is decimal time;

$x_{t}$ is a vector of ancillary predictors such as the sine and cosine functions of decimal time; and

$e_{t}$ is an independent and identically normally distributed random error. 
The multi-element vector function of the logarithm of streamflow, consisted of the logarithm of streamflow and the square of the logarithm of streamflow; the multi-element vector function of decimal time consisted of second-order polynomial terms and step functions of decimal time.

The water-quality model was estimated using either ordinary least squares if the water-quality data contained no censored observations or the maximum-likelihood estimation method if censored observations were present. The maximumlikelihood estimation bias adjustment required estimates of the detection level even for uncensored observations; the detection level was set equal to the maximum of the median detection level for all censored observations across all study sites or to a minimum reported uncensored value.

The estimate of NFA trends in concentration was based on the streamflow and time-trend coefficients from the waterquality model $\left(b_{\mathrm{q}}\right.$ and $\left.b_{\mathrm{T}}\right)$ and the coefficient on decimal time in the streamflow model, subsequently denoted as $a$. The trend in the logarithm of streamflow during period $t$ (between $t_{1}$, the beginning of the streamflow analysis period in 1993, and $t_{2}$, the end of the streamflow analysis period in 2004), $\tilde{q}_{t}$, was defined as:

$$
\tilde{q}_{t}=\bar{q}+a\left(T_{t}-\bar{T}\right)
$$

where $\bar{q}$ and $\bar{T}$ are the means of the logarithm of streamflow and decimal time over the analysis period. If streamflow was upward trending, then $a$ was positive, and the trend in the logarithm of streamflow was less than the mean value of the logarithm of streamflow for the first one-half of the analysis period and greater than the mean value thereafter. Note that the average of the logarithm of streamflow, $\bar{q}$, implicitly accounted for the intercept and average of the seasonal terms that are included in the streamflow model but not otherwise apparent in the formulation of equation 3 .

The trend in water-quality concentrations during period $t$ (between $t_{1}$, the beginning of the concentration analysis period in 1993, and $t_{2}$, the end of the concentration analysis period in 2003), $\tilde{c}_{t}$, was defined as:

$$
\tilde{c}_{t}=m\left(\tilde{q}_{t}\right) b_{q}+h\left(T_{t}\right) b_{T} .
$$

Only terms involving trends were included in equation 4. Note that in forming this estimate, the trend in the logarithm of streamflow was substituted for the actual logarithm of streamflow in the function $m(\cdot)$. This implied that variations in streamflow not reflected in the trend did not determine the proposed measure of the NFA trend in concentration. Because of the nonlinearity of the function $m(\cdot)$, this might have led to a bias in the evaluation of the NFA trend if streamflows were becoming more or less variable over time. The streamflow and concentration trends were calculated for slightly different periods (1993 to 2004 and 1993 to 2003, respectively) because these analyses were completed as part of a larger national analysis that required flexibility in the streamflow period.
The difference in the final NFA trend resulting from a streamflow period between 1993 and 2004 and that resulting from a streamflow period between 1993 and 2003 likely is small (Greg Schwarz, U.S. Geological Survey, written commun., 2006).

The NFA trend in concentration depended on the trend and streamflow coefficients from the water-quality model, $b_{q}$ and $b_{T}$, as well as the trend coefficient $a$ from the streamflow model. The NFA trend over the analysis period, $\tau_{c}$, was defined as:

$$
\begin{aligned}
\tau_{c} & =\tilde{c}_{t_{2}}-\tilde{c}_{t_{1}}=\left\{\left[m\left(\tilde{q}_{t_{2}}\right)-m\left(\tilde{q}_{t_{1}}\right)\right] b_{q}\right\}+\left\{\left[h\left(T_{t_{2}}\right)-h\left(T_{t_{1}}\right)\right] b_{T}\right\} \\
& =\left\{\left[m\left(\bar{q}+a\left(T_{t_{2}}-\bar{T}\right)\right)-m\left(\bar{q}+a\left(T_{t_{1}}-\bar{T}\right)\right)\right] b_{q}\right\}+\left\{\left[h\left(T_{t_{2}}\right)-h\left(T_{t_{1}}\right)\right] b_{T}\right\}^{*}
\end{aligned}
$$

The NFA trend in concentration, expressed as the average percentage change per year, $\frac{\% \Delta \mathrm{NFAC}}{y r}$, was defined as:

$$
\frac{\% \Delta \mathrm{NFAC}}{y r}=100 \times \frac{\left(\mathrm{e}^{\tau_{c}}-1\right)}{T_{t_{2}}-T_{t_{1}}} .
$$

The 95-percent confidence interval of the trend was calculated by use of the standard deviation of $\tau_{c}$.

The estimate of the NFA trend in concentration was obtained by substituting sample estimates for the population values of $a, b_{q}$, and $b_{T}$ in equation 5. The standard error of the resulting estimate was complicated to derive owing to the nonlinear manner in which the streamflow trend coefficient and the water-quality and streamflow coefficients interact in the determination of the NFA trend. An approximation to the standard error suitable for large samples (30 or more) was obtained by taking a first-order Taylor approximation of the NFA trend estimate from equation 5 with respect to the streamflow and water-quality model coefficients. The vector of combined streamflow and trend coefficients from the water-quality model was represented by $b=\left\{b_{q}^{\prime} b_{T}^{\prime}\right\}^{\prime}$, and the covariance matrix of this vector was represented by $V_{b}$. Under the plausible assumption that streamflow was exogenous with respect to water quality, meaning that changes in streamflow caused changes in water quality but changes in water quality did not cause changes in streamflow, the covariance between the estimated values of $a$ and $b$ was zero. Consequently, the standard error of $\tau_{c}$, denoted as $\sigma_{c}$, was defined as:

$$
\sigma_{c}=\sqrt{V_{a}\left(\frac{\partial \Delta m}{\partial a} b_{q}\right)^{2}+A V_{b} A^{\prime}},
$$

where

$V_{a}$ is the variance of the estimated streamflow trend coefficient, $a$;

$$
\frac{\partial \Delta m}{\partial a}=\frac{\partial m\left(\bar{q}+a\left(T_{t_{2}}-\bar{T}\right)\right)}{\partial a}-\frac{\partial m\left(\bar{q}+a\left(T_{t_{1}}-\bar{T}\right)\right)}{\partial a} ;
$$


and

$A=\left\{m\left(\bar{q}+a\left(T_{t_{2}}-\bar{T}\right)\right) h\left(T_{t_{2}}\right)\right\}-\left\{m\left(\bar{q}+a\left(T_{t_{1}}-\bar{T}\right)\right) h\left(T_{t_{1}}\right)\right\}$.

In large samples, the t-statistic $\tau_{c} / \sigma_{c}$ is distributed standard normal. Therefore, the two-sided p-value for significance of the trend was calculated as:

$$
p=2\left[1-\Phi\left(\left|\tau_{c} / \sigma_{c}\right|\right)\right]
$$

where

$\mathrm{p}$ is the two-sided $\mathrm{p}$-value for significance of the trend; and $\Phi(\cdot)$ is the standard-normal cumulative distribution.

Trend results were considered significant if the p-value was less than or equal to 0.05 .

\section{Streamflow}

Because serial correlation in the residuals of equation 3 was not fully removed by the AR(20) model for all sites and because the period of record for the streamflow data used in the determination of NFA trends was from 1993 to 2004, monotonic trends in monthly mean discharge from 1993 to 2003 were estimated separately from the NFA trend analysis using the nonparametric seasonal Kendall test (Helsel and Hirsch, 1992). In the seasonal Kendall test, each data pair is compared to all others within a given month in a pairwise fashion; the median of all possible pairwise slopes across months is the estimate of the trend slope. For this study, 12 monthly seasons were used. The seasonal Kendall test was performed by use of the seaken procedure in S-plus version 6.1, release 1 (Insightful Corporation, 2002). Trend results were considered significant if the $\mathrm{p}$-value was less than or equal to 0.05 . The median daily streamflow from 1993 to 2003 at each site was calculated for use as the reference streamflow value, presented in this report together with the trend results.

\section{Changes in Nutrient Sources and Landscape Characteristics from 1993-2003}

Trends in concentration are affected by changes in nutrient sources and landscape characteristics upstream. To aid in interpreting the nutrient and SS trends, important nutrient sources and landscape characteristics were examined over the study period for each site.

\section{Data Sources}

Geographic information system (GIS) software (ESRI, 2005) was used for spatial overlay analyses of the drainagearea polygons (or equivalent raster representation thereof) with digital thematic maps of nutrient sources and landscape characteristics. The spatial resolution of the thematic characteristics varied according to the scale or resolution of the source data. For many of the thematic characteristics, a time series of digital maps was available that was analyzed by a corresponding series of spatial overlays to produce a temporal series of basin characteristics. The nutrient sources and landscape characteristics included fertilizer use for nitrogen and phosphorus, manure generation for nitrogen and phosphorus, atmospheric deposition for nitrogen, point-source loading for nitrogen, population density, and management practices (including irrigation type and conservation practices such as contour farming) (table 2). When drainage basins only partially extended into one or more counties, county-level data were apportioned according to the amount of agricultural or urban land contained within the drainage basin, as described by Nakagaki and Wolock (2005).

Fertilizer and manure data were based on county-level estimates assigned to specified land uses within each county and then summed for the area within each drainage basin; data include nitrogen and phosphorus in commercial fertilizers used on farms and in urban settings and nitrogen and phosphorus in livestock manure. For this report, farm and urban fertilizer data were combined, and confined and unconfined manure data were combined. Data for nitrogen in atmospheric deposition were derived from 1-km resolution grids of atmospheric deposition that were based on data from the National Atmospheric Deposition Program. More detail on fertilizer, manure, and atmospheric deposition data generation can be found in Ruddy and others (2006). The population data were derived from a 30-m resolution grid of census block groups and population counts that were based on the 1990 and 2000 census of population and housing (U.S. Census Bureau, 1991, 2000).

Data for point-source loading of nitrogen from permitted dischargers were estimated using available monitoring data contained in the U.S. Environmental Protection Agency's Permit Compliance System. During the processing of these data, about 50 percent of the records ultimately were excluded because of missing or uninterpretable information. The effect of these excluded records on the nitrogen-loading estimates is unknown but is likely substantial. More information on the processing of the point-source data can be found in Appendix 1.

The management practices data were derived from 30-m resolution grids of selected 1992 and 1997 National Resources Inventory (NRI) parameters compiled by the Natural Resources Conservation Service (U.S. Department of Agriculture, 1995, 2001). These data were aggregated to agricultural land use at the county level and then summed for the area within each drainage basin. Total irrigated area was calculated as the sum of the following codes within the NRI "irrigation types" category-gravity irrigated, pressure irrigated, and gravity and pressure irrigated. Total area in conservation practices was calculated as the sum of the following codes within the NRI category "conservation practices"-contour farming, irrigation system (tailwater recovery), and terrace. Several potentially influential conservation practices that had been present in the $1992 \mathrm{NRI}$, including conservation tillage 
Table 2. Sources, types, and temporal coverage of data on nutrient sources and landscape characteristics in the Missouri River Basin.

$[\mathrm{N}$, nitrogen; P, phosphorus]

\begin{tabular}{|c|c|c|c|c|c|}
\hline $\begin{array}{l}\text { Nutrient source/ } \\
\text { landscape } \\
\text { characteristics }\end{array}$ & $\begin{array}{l}\text { Data } \\
\text { source }\end{array}$ & Data type & $\begin{array}{c}\text { Time } \\
\text { period }\end{array}$ & Online data and information availability ${ }^{1}$ & $\begin{array}{c}\text { Data } \\
\text { analysis } \\
\text { group }\end{array}$ \\
\hline $\begin{array}{l}\text { Fertilizer use ( } \mathrm{N} \\
\text { and } \mathrm{P})\end{array}$ & $\begin{array}{l}\text { Association of Ameri- } \\
\text { can Plant Food } \\
\text { Control Officials }\end{array}$ & Fertilizer sales & $\begin{array}{r}\text { Annually, } 1993 \\
\text { through } 2003\end{array}$ & http://pubs.usgs.gov/sir/2006/5012/ & $1993-2003$ trends \\
\hline $\begin{array}{l}\text { Manure generation } \\
\quad(\mathrm{N} \text { and } \mathrm{P})\end{array}$ & Census of Agriculture & Livestock populations & $\begin{array}{l}\text { 1992, 1997, and } \\
2002\end{array}$ & http://pubs.usgs.gov/sir/2006/5012/ & $1993-2003$ trends \\
\hline $\begin{array}{l}\text { Atmospheric } \\
\text { deposition }(\mathrm{N})\end{array}$ & $\begin{array}{l}\text { National Atmospheric } \\
\text { Deposition Program }\end{array}$ & $\begin{array}{l}\text { Wet deposition } \\
\text { chemistry }\end{array}$ & $\begin{array}{r}\text { Annually, } 1993 \\
\text { through } 2003\end{array}$ & http://pubs.usgs.gov/sir/2006/5012/ & 1993-2003 trends \\
\hline $\begin{array}{l}\text { Point-source } \\
\text { loading }(\mathrm{N})\end{array}$ & $\begin{array}{l}\text { U.S. Environmental } \\
\text { Protection Agency }\end{array}$ & $\begin{array}{l}\text { Concentration, dis- } \\
\text { charge, and loading } \\
\text { from point sources }\end{array}$ & $\begin{array}{r}\text { Annually, } 1993 \\
\text { through } 2003\end{array}$ & http://www.epa.gov/enviro/html/pcs/ & 1993-2003 trends \\
\hline Population density & U.S. Census Bureau & Human population & 1990 and 2000 & $\begin{array}{l}\text { http://www.census.gov/main/www/cen1990.html } \\
\text { http://www.census.gov/main/www/cen2000.html }\end{array}$ & $1993-2003$ trends \\
\hline $\begin{array}{l}\text { Management } \\
\text { practices }\end{array}$ & $\begin{array}{l}\text { Natural Resources Con- } \\
\text { servation Service }\end{array}$ & $\begin{array}{l}\text { Irrigation type and } \\
\text { conservation } \\
\text { practices }\end{array}$ & 1992 and 1997 & http://www.nrcs.usda.gov/TECHNICAL/NRI/ & $\begin{array}{l}1993-2003 \text { trends; } \\
\text { spatial sediment }\end{array}$ \\
\hline Soil properties & $\begin{array}{l}\text { Natural Resources Con- } \\
\text { servation Service }\end{array}$ & $\begin{array}{l}\text { Soil-erodibility factor, } \\
\mathrm{K} \text {, and soil runoff } \\
\text { factor, } \mathrm{R}\end{array}$ & Variable & http://www.ncgc.nrcs.usda.gov/products/datasets/statsgo/ & Spatial sediment \\
\hline $\begin{array}{l}\text { Land use/land } \\
\text { cover }\end{array}$ & U.S. Geological Survey & $\begin{array}{l}\text { Percentage cultivated } \\
\text { area }\end{array}$ & Early 1990’s & http://edc.usgs.gov/products/landcover/nlcd.html & Spatial sediment \\
\hline Physiography & $\begin{array}{l}\text { Fenneman and Johnson } \\
\quad(1946)\end{array}$ & $\begin{array}{l}\text { Percentage in the } \\
\text { Interior Plains } \\
\text { physiographic } \\
\text { division }\end{array}$ & 1946 & http://water.usgs.gov/lookup/getspatial?physio & Spatial sediment \\
\hline $\begin{array}{l}\text { Hydrologic } \\
\text { landscape regions }\end{array}$ & U.S. Geological Survey & $\begin{array}{l}\text { Regions of the Mis- } \\
\text { souri River Basin }\end{array}$ & 2003 & http://water.usgs.gov/lookup/getspatial?hlrus & Spatial sediment \\
\hline Hydrography & $\begin{array}{l}\text { U.S. Geological Survey } \\
\text { national hydrography } \\
\text { data set }\end{array}$ & $\begin{array}{l}\text { Stream length (used } \\
\text { in stream-density } \\
\text { calculations) }\end{array}$ & $\begin{array}{l}\text { Current through } \\
2005\end{array}$ & http://nhd.usgs.gov/data.html & Spatial sediment \\
\hline Reservoirs & $\begin{array}{l}\text { National inventory of } \\
\text { dams }\end{array}$ & $\begin{array}{l}\text { Percentage unregu- } \\
\text { lated area }\end{array}$ & $\begin{array}{l}\text { Current through } \\
2005\end{array}$ & http://crunch.tec.army.mil/nid/webpages/nid.cfm & Spatial sediment \\
\hline
\end{tabular}

${ }^{1}$ All Web sites accessed on June 1, 2006. 
systems, irrigation land management, irrigation land leveling, and subsurface drains, were no longer present in the 1997 NRI; only codes that were compiled in 1992 and 1997 were included in the evaluation of trends herein. The conservation practices that were not included in the 1997 NRI, particularly conservation tillage systems, may have had a substantial effect on water-quality trends in the Missouri River Basin; any such effects would not be reflected in the analysis of management practices in this report. More comprehensive data on management practices likely would have improved the interpretation of trends in this report.

Total irrigated area and total area in conservation practices were normalized to the basin area in cultivated lands to facilitate comparison between basins. Similarly, all other nutrient sources and landscape characteristics were normalized to the total basin area. Because of differences in the grouping of level 2 land-cover categories during the original compilation of the NRI data and during the normalization to cultivated area for this study, final percentages of the cultivated area containing irrigation or conservation practices sometimes may be slightly greater than 100 .

At site 6, approximately 98 percent of the drainage area is in Canada, which is not included in the ancillary-data coverage. All of the computed basin characteristics were based on the 2 percent contained within the conterminous United States. As a result, this site was excluded from any subsequent analyses relating trends and factors affecting those trends. In addition, at sites 22 and 23, county-level NRI data were missing for a large number of counties in the drainage area; as a result, these sites were excluded from subsequent analyses relating trends to total irrigated area and total area in conservation practices. County-level NRI data were missing in the drainage area of several other sites, but because the NRI data were apportioned according to the amount of non-Federal agricultural land within the county and these counties did not contain substantial agricultural activity or contained large areas of Federal lands, the lack of data was not considered to be as problematic at those sites, and they were included in all subsequent analyses.

\section{Relating Trends and Factors Affecting Trends}

To compare the FA and NFA trends in concentration to factors affecting those trends regionally, weighted leastsquares regression between trend values and ancillary data values was used. With weighted least-squares regression, each trend value was weighted so that values that were known with more confidence (those with less variance) had a greater weight in the regression than values that were known with less confidence (those with greater variance) (Helsel and Hirsch, 1992). In this way, trends with less variance had a stronger effect on the regression. Weights were based on the inverse of the variance of the FA and NFA trend estimates for each constituent at each site:

$$
w_{i}=\frac{1}{s_{T R}^{2}},
$$

where

$w_{i}$ is the weight of each site-constituent combination in group $\mathrm{i}$; and

$s_{T R}^{2}$ is the variance of the trend estimate.

To use the data for nutrient sources and landscape characteristics in weighted least-squares regression, a single number representing the change in a given data series over time was generated. When a data series had more than two observations (for example, an annual data series for fertilizer), the Sen slope estimate for that series was determined for each site. The Sen slope estimate was calculated as the median of all possible pairwise slopes (Helsel and Hirsch, 1992). When a data series had only two observations (for example, 1990 and 2000 estimates of population density), the percentage change between the first year and the last year was determined for each site.

\section{Scale-Dependency in Relating Trends and Factors Affecting Trends}

Previous studies have demonstrated that there is a plausible basis for hypothesizing that nutrient and SS concentrations may be more affected by nutrient sources and landscape characteristics in the most downstream parts of a drainage area than those in the full drainage area (Walling, 1983; Creed and Band, 1998; Gburek and others, 2002; Miller and others, 2005). Transport of some constituents may occur more readily than others; for example, very fine particulates and associated adsorbed compounds are transported preferentially downstream, whereas coarser material may become stored preferentially in flood-plain or channel deposits. Additionally, water-quality constituents vary in their availability for initial mobilization, the hydrologic pathways they likely will follow, and their susceptibility to physical, chemical, or biological transformation during transport. Nutrients commonly undergo in-stream transformations and biological uptake, so that a disproportionate amount of the nutrient load in some rivers may originate in the most downstream parts of the drainage area. Nutrient sources and landscape characteristics in the full drainage area and the nearest 10-percent drainage area were examined to determine where management practices could best be focused within a drainage basin to produce measurable changes in water quality.

GIS software was used to delineate the nearest 10-percent areal subset of the drainage area for each of the sites used in the analysis of trends between 1993 and 2003. Because of limited computing resources, the following procedure could not be completed for the two sites with the largest drainage areas, sites 44 and 58. The processing steps involved the application of standard and customized spatial analysis algorithms for hydrologic analyses of digital elevation models that had first been processed for the elevation derivatives for national applications project (U.S. Geological Survey, 2005) to virtually fill surface depressions that otherwise would have blocked routing of overland flow. Surface-runoff direction 
was mapped using the flow-direction algorithm (ESRI, 2005). Those runoff-direction maps subsequently were analyzed using the flow-length algorithm (ESRI, 2005) to calculate the total distance from the watershed outlet (defined by the sampling site) along surface-runoff flow paths to each $900-\mathrm{m}^{2}$ grid cell composing the raster representation of the drainage area. Next, a custom algorithm (Appendix 2) was used to: (1) extract a subset of each runoff-distance map consisting of all grid cells having runoff distance less than a specified threshold value and (2) compare the area of the extracted subset with a criterion determined beforehand as a target percentage of the total drainage area for the specific sampling site being analyzed. The algorithm used an iterative approach to find the specific threshold value of runoff distance that yielded an areal subset of the nearest 10 percent of the drainage area. An iteration was considered successful if it produced a subset having an area between 9.9 and 10.1 percent of the total drainage area (that is, within 1 percent of the target size). The algorithm was applied to produce a digital map of the areal extent of the 10 percent of the respective drainage area nearest to each of the trend sites. Finally, the 10-percent areal subset of nearest drainage area was characterized using spatial overlay analyses of its boundary polygon (or equivalent raster representation thereof) with the digital thematic maps of nutrient sources and landscape characteristics.

Data for the changes in nutrient sources and landscape characteristics in the 10-percent areal subset of the drainage area were used in the weighted least-squares regression analysis with the trend values. The results were compared to the weighted least-squares regression results obtained by using the changes in nutrient sources and landscape characteristics in the full drainage area to examine the scale-dependency of the relation between trends and the factors affecting those trends from 1993 to 2003.

\section{Trends from 1985 to 2003}

A significant monotonic trend for the period from 1993 to 2003 indicates that concentrations in 2003 were either higher or lower than in 1993, but it does not indicate how the increase or decrease occurred. For example, a step trend in 1998, a linear trend from 1993 to 1998, or a linear trend from 1998 to 2003 all may result in a significant trend for the period from 1993 to 2003. Furthermore, a trend in concentration from 1993 to 2003 may or may not be part of a longer term monotonic increase or decrease in concentration. To provide more detail on the nature of the FA trends in concentration from 1993 to 2003 and to place them into a longer context, a subset of sites was selected for longer term analysis of FA trends in concentration for the period from 1985 to 2003 using the waterquality model QWTREND. The QWTREND model jointly analyzes streamflow and concentration using a parametric time-series analysis procedure (Vecchia, 2005). Time-series analysis can be used to evaluate data for non-monotonic trends (trends that have one or more changes in slope during the period being evaluated), such as cyclic trends and combinations of linear and step trends. The QWTREND model also is useful for evaluating trends at a group of sites where sampling frequencies have been highly variable from year to year. Other studies in Connecticut (Trench and Vecchia, 2002; Trench, 2004), North Dakota (Vecchia, 2000, 2003), and South Dakota (Sando and Neitzert, 2003) have applied the QWTREND model to examine trends in water quality.

Of the 35 sites used in the analysis of trends from 1993 to 2003, 18 met the data requirements of the QWTREND model:

- a full record of daily mean streamflow from 5 years before the first water-quality sample was collected through the end of the water-quality sampling record (in this case, 1980 to 2003),

- at least 15 years of water-quality data (although not necessarily consecutive),

- an average of at least four samples per year, and

- 10 percent or fewer of the values reported as censored values.

Trend analysis from 1985 to 2003 was conducted for TN at nine sites, NOX at five sites, TP at seven sites, OP at four sites, and SS at seven sites (table 1). NH3 was not included in the analysis because all of the sites had more than 10 percent of the values reported as censored values.

Concentrations of water-quality constituents commonly are related to streamflow. Variations in streamflow may exist on many different time scales, such as daily, seasonally, and annually, which can affect concentrations in complex and diverse ways. The QWTREND model filtered out as much natural streamflow-related variability in concentration as possible before analyzing for concentration trends. The model also filtered out serial persistence, or autocorrelation, between constituent concentrations that are adjacent in time; autocorrelation can bias estimated trends and their significance levels. The model separated streamflow data into components of annual variability, seasonal variability, and high-frequency deviations from the basic conditions, or "noise." The form of the time-series model (Trench and Vecchia, 2002, p. 10) used to analyze variability in streamflow can be expressed as:

$\mathrm{X}=\mathrm{C}+\mathrm{A}+\mathrm{S}+\mathrm{U}$,

where

$\mathrm{X}$ is the base-10 logarithm of daily mean streamflow;

$\mathrm{C}$ is a constant (the overall mean of the streamflow data);

A is the time series that represents annual variability in streamflow;

$\mathrm{S}$ is the time series that represents seasonal variability in streamflow; and

$\mathrm{U}$ is the time series of deviations from the streamflow values represented by $\mathrm{C}+\mathrm{A}+\mathrm{S}$. 
The model separated concentration data into components of annual variability, seasonal variability, trend, and highfrequency deviations from the basic conditions, or noise. The form of the time-series model used to analyze variability in concentration can be expressed as:

$\mathrm{Y}=\mathrm{C}+\mathrm{A}+\mathrm{S}+\mathrm{T}+\mathrm{W}$

where

$\mathrm{Y}$ is the base-10 logarithm of concentration;

$\mathrm{C}$ is a constant (the overall mean of the concentration data);

$\mathrm{A}$ is the time series that represents annual variability in concentration;

$\mathrm{S}$ is the time series that represents seasonal variability in concentration;

$\mathrm{T}$ is the trend in concentration; and

$\mathrm{W}$ is the time series of deviations from the concentration values represented by $\mathrm{C}+\mathrm{A}+\mathrm{S}+\mathrm{T}$.

The model initially determined the low-frequency component in streamflow, which consisted of the streamflow constant, the annual variability, and seasonal variability. A smoothing algorithm was used to separate the low-frequency (annual and seasonal) variability from the high-frequency variability (U), which was defined as the deviation of the recorded values from the low-frequency component. Low-frequency and high-frequency variabilities in streamflow typically were important factors for describing variability in concentrations. Next, the low-frequency component of concentration, which included annual and seasonal variability, was estimated from a nonlinear regression of concentration and the low-frequency component of streamflow. In the flow-adjustment process, the low-frequency component of concentration was filtered out, and the resulting flow-adjusted concentration was the constant plus any trend component of concentration plus the high-frequency deviations in concentration, or noise (W). In general terms, these flow-adjusted concentrations represent the concentrations that would have been observed if the flow conditions had been uniform throughout the entire sampling period (Vecchia, 2005).

In addition to accounting for low-frequency variability in streamflow and concentration, the QWTREND model also included a periodic autoregressive moving average model that was used to detect and filter out complex statistical properties of the high-frequency deviations in concentration and streamflow such as autocorrelation (Vecchia, 2005). The QWTREND model initially was applied to concentrations at each site without a specified trend period. After the periodic autoregressive moving average model was applied to the highfrequency deviations in concentration, the residuals (representing the unexplained remnant of concentration variability, plus any trends that may be present) were examined for patterns (Trench and Vecchia, 2002). A locally weighted, scatterplot smoothing (LOWESS) curve, which indicates trend directions and major changes in slope during the period of record, was added to the plot of the residuals to aid in identifying central patterns in the data. After potential trend periods had been identified, the QWTREND model was reapplied with the trend period(s) specified. The trend models were evaluated numerically and compared to the initial model results where no trend period had been specified; $p$-values for the various trend models were calculated to select the trend model that best represented the flow-adjusted trend in concentrations for a constituent from 1985 to 2003. Finally, residual plots for the selected model were examined to ensure that the residuals had no remaining trend patterns and met the assumptions of normality and homoscedasticity. Trend results were considered significant if the p-value for the model statistic was less than or equal to 0.05 .

Potential trends between 1985 and 2003 included a monotonic trend during a single time period or a non-monotonic trend consisting of monotonic trends during multiple time periods. On the basis of variable sampling frequencies at the sites, a minimum trend period of 5 years was used. Preliminary model testing indicated that common trend periods existed at multiple sites; these common periods included 1985 to 1991,1985 to 1996,1985 to 2003,1992 to 1996,1992 to 2003, and 1997 to 2003. In some cases, the best model fit may have varied slightly from the common time periods by a year or two; however, these common time periods were used for all of the long-term trend sites to maintain consistency in the trend analysis. If the trend periods from 1985 to 2003 and 1992 to 2003 were both significant, the model results from 1985 to 2003 were retained to compare the longer term trend results with the trend results from 1993 to 2003 determined using the LOADEST model. The median of the observed concentrations between 1985 and 2003 was used as the reference concentration for these longer term trends; the reference concentrations are presented in this report together with the trends from 1985 to 2003.

Trends in streamflow (and hence NFA trends in concentration) could not be determined for the period from 1985 to 2003 using the QWTREND model because the model does not explicitly include a streamflow trend. Instead, a time series of streamflow consisting of the daily mean streamflow on three dates per month (the 5th, 15th, and 25th day of each month) was constructed for each site and used to create a hydrograph. This process was similar to how the QWTREND model assigned streamflow values in the time-series analysis, where each month was divided into approximately 10-day intervals. The hydrographs were inspected graphically for general patterns in the streamflow data from 1985 to 2003; a LOWESS curve was added to the hydrographs to help identify these patterns.

Detailed information on the QWTREND model is available in Vecchia (2000, appendix A; 2005, Appendix 1), and a summary of the model is provided in Trench and Vecchia (2002). 


\section{Supporting Analyses}

\section{Effect of Ground Water on Surface-Water Nitrate Trends}

Many pollution-control strategies implemented in the Missouri River Basin have focused on controlling surface runoff of nutrients and sediment. Ground-water inflow, however, can contribute substantially to flow and nutrient loading in streams. For example, in nontidal streams of the Chesapeake Bay watershed, base flow accounted for 16 to 92 percent of total streamflow, and base-flow nitrate load accounted for 26 to nearly 100 percent of the stream nitrate load (Bachman and others, 1998). To better understand the potential effect of ground water on surface-water nitrate loading in the Missouri River Basin, ground-water contributions to streamflow and stream loading of NOX were examined at a subset of trend sites representing a range of hydrogeologic and climatic conditions.

\section{Site Selection}

Although the initial pool of potential sites for the baseflow analyses was the same as that used for the analysis of trends from 1993 to 2003, the site-selection criteria were modified to improve the accuracy of the hydrograph separation. Hydrograph separation can be inaccurate in large basins because of contributions from upstream flow, so sites were limited to river basins with a contributing area of $1,295 \mathrm{~km}^{2}$ or less. Hydrograph separation also can be inaccurate in basins where natural streamflow is altered by flow regulation or where there is substantial irrigation return flow. Because of these limitations, the basins selected had a contributing area less than $1,295 \mathrm{~km}^{2}$, minimal flow regulation, and minimal irrigated cropland.

The three sites ultimately selected represented a range of hydrogeologic and climatic conditions. Site 1, located in the Great Plains physiographic province in Montana (fig. 2), has a drainage area of about $662 \mathrm{~km}^{2}$. The surface geology is shale (52 percent), lake deposits (47 percent), and a small amount of alluvium (less than 1 percent). Pollutioncontrol strategies have been implemented in this basin in an effort to decrease sediment erosion from agricultural areas (Conservation Technology Information Center, 2006; Natural Resources Conservation Service, 2006). Site 39, located in the Great Plains physiographic province (fig. 2) in the Sand Hills of Nebraska, has a drainage area of 2,503 $\mathrm{km}^{2}$ (and a contributing drainage area of $77 \mathrm{~km}^{2}$ ). Because of the sandy soils in the Sand Hills, nearly all of the precipitation infiltrates directly to ground water rather than entering the stream through surface runoff (Frenzel and others, 1998). The surface geology is primarily sand sheets (91 percent) and alluvium (9 percent). Site 53, located in the Ozark Plateaus physiographic province in Missouri (fig. 2), has a contributing drainage area of $713 \mathrm{~km}^{2}$. The surface geology is primarily red clay (86 percent) and alluvium (14 percent). Wastewater discharge, agricultural activity, and urbanization have affected water-quality conditions at this site in recent years (Missouri Department of Conservation, 2006).

\section{Ground-Water Discharge and Load Estimation}

Ground-water discharge to the stream in the three casestudy basins was estimated using the hydrograph-separation program PART (Rutledge, 1998). For this report, ground-water discharge was considered to be the primary source of base flow to the streams. Using continuous daily mean values of streamflow, the PART program separated streamflow into components of runoff and base flow by setting base flow equal to streamflow on days that met a requirement of antecedent recession and linearly interpolating base flow on other days. The requirement for antecedent recession accounted for streamflow that likely was from interflow or surface runoff rather than base flow.

The daily values of ground-water discharge from PART were used to estimate loads of NOX in base flow. At each site, a predictive model was calibrated with parametric multiple-regression analysis by use of the LOADEST model as described previously. The models were calibrated using surface-water concentrations of NOX on days when the base flow was greater than 80 percent of the total streamflow as the dependent variable and various functions of base flow, decimal time, and season as independent predictive variables. Model calibration generally followed the same procedures as used in the analysis of trends from 1993 to 2003, with one notable exception. When model residuals were determined to be nonnormal and there were no censored values in the concentration data set, least-absolute deviation (LAD) procedures (Runkel and others, 2004) were used in place of adjusted maximumlikelihood estimation techniques to develop the model. Once the load models had been calibrated, estimates of NOX loads in base flow were made at each site using a continuous record of daily base flow from the PART program. Similarly, estimates of NOX loads in surface water were made using the models calibrated during the analysis of trends from 1993 to 2003 in conjunction with a continuous record of daily mean streamflow. The estimates of loads from base flow were compared to the estimates of loads in surface water to determine the contribution of base flow to surface-water nitrate loads from 1993 to 2003.

\section{Spatial Patterns in Sediment Yields}

SS yields were estimated for 32 sites (spatial-sediment trend sites in table 1) and compared to potentially influential landscape characteristics to identify important factors related to spatial patterns of SS yields in the Missouri River Basin. These important factors then were examined to determine their influence, if any, on temporal trends in SS. 


\section{Site Selection}

Sites were selected for the analysis of spatial patterns in SS yield on the basis of the following minimum criteria:

- approximately monthly sampling for three consecutive years between 1987 and 2002;

- continuous daily streamflow for at least 2 years within the 3-year period of sampling; and

- representative coverage of samples over the hydrograph, wherever possible.

To avoid the effects of temporal changes at the final sites, yield estimates were derived for a 3-year period. To maximum site coverage, the 3-year period for each site was selected from a 15-year window that began with the first NAWQA datacollection activities in the Missouri River Basin in 1987. To the extent possible, overlapping 3-year periods were selected at the sites.

\section{Load Estimation}

SS loads were estimated by use of the LOADEST model as described previously, with one notable exception. Because natural hydrologic variability among sites can confound identification of landscape characteristics affecting spatial patterns in load, a streamflow record reflecting the average condition at each site was used in place of the actual streamflow to minimize the effect of hydrologic variability on the load estimates. This median streamflow data set was derived at each site by: (1) compiling the annual streamflows for each calendar year of record, (2) identifying the three calendar years closest to the median of the annual streamflow (with the exception of sites with five or fewer years of streamflow record, where the 2 years closest to the median were used to avoid high or low bias in the load estimates), (3) compiling the daily mean streamflow records corresponding to the three (or two) calendar years identified in the previous step, and (4) replacing the streamflow data during the years corresponding to the calibration data with this median streamflow data. This approach had the advantage of producing load estimates with less hydrologic variability among sites, which facilitated identification of landscape characteristics affecting spatial patterns in load. However, these load estimates are not representative of real-world conditions; they cannot be interpreted as loads that actually occurred at any point in time at these sites.

The total load estimates were divided by the number of days in the record and the contributing drainage area (Appendix 8) to produce the mean daily sediment yield (MDSY) at each site. The MDSYs were used in all subsequent analyses.

\section{Comparison of Sediment Yields to Landscape Characteristics}

Landscape characteristics were characterized for each site by overlaying the boundary of the contributing drainage area (Godberson and others, 2006) on the following
GIS digital thematic maps: State Soils Geographic Database (STATSGO) soil properties (Natural Resources Conservation Service, 1994), physiographic divisions (Fenneman and Johnson, 1946), hydrologic landscape regions (Winter, 2001; Wolock, 2003), the 1:100,000 scale national hydrography data set, and the 1992 multiresolution land characteristics data set (Vogelmann and others, 2001). Physiographic divisions are composed of related physiographic provinces, areas of similar terrain that have been shaped by a common geologic history; hydrologic landscape regions identify areas with similar hydrologic characteristics. When the basins only partially extended into one or more counties, county-level data was apportioned according to the amount of agricultural or urban land contained within the drainage basin, as described by Nakagaki and Wolock (2005).

From these data sets, eight primary factors were derived to represent the landscape characteristics: (1) soil-erodibility factor, K; (2) soil-runoff factor, R; (3) percentage cultivated area; (4) percentage in the Interior Plains physiographic division; (5) percentage in the hydrologic landscape regions categorized as Plains; (6) stream density; (7) the natural logarithm of contributing drainage area; and (8) percentage unregulated area. The $\mathrm{K}$ and $\mathrm{R}$ factors were computed as the mean values for each drainage basin. The percentage cultivated area reflected the sum of four categories (orchards/vineyards/other, row crops, small grains, and fallow) given in the 1992 land cover data. The percentage of the basin area in the Interior Plains physiographic division was used as an index to describe the basin physiography. A similar index was used to describe the hydrologic landscape regions by summing any of the hydrologic landscape regions associated with the plains (hydrologic landscape regions 1-8). Stream density was calculated as the length of the hydrography divided by the basin area. Because of the large range in drainage areas, the natural logarithm of drainage area was used as a representative index in the comparisons. The percentage of unregulated area was used to represent the part of the basin not affected by reservoirs with more than $49.3 \times 10^{6} \mathrm{~m}^{3}$ of storage.

The MDSYs were compared to the corresponding landscape characteristics using weighted least-squares regression. Graphical comparisons indicated a nonlinear relation of MDSYs to the landscape data; MDSYs were log transformed as a result. For each site, the weighting factor, $\mathrm{w}_{i}$, was calculated as the inverse of the variance, as follows:

$$
w_{i}=\frac{1}{s_{M D S Y}^{2}},
$$

where

$w_{i}$ is the weight of the mean daily sediment yield estimate for site $i$; and

$s_{M D S Y}^{2}$ is the variance of the mean daily sediment yield estimate. 


\section{Nutrient and Suspended-Sediment Trends}

\section{Streamflow}

\section{Trends from 1993 to 2003}

Significant (p-value less than 0.05) downward trends in streamflow were detected at 26 of the 34 sites (fig. 3, Appendix 3). The downward trends occurred throughout the basin from the headwaters to the lower main stem of the Missouri River. Large areas of the Missouri River Basin experienced drought conditions during the latter part of the study period. Spring runoff from snowpack in the Rocky Mountains, a large source of water to the Missouri River, was less than the long-term average each year between 2000 and 2003 (U.S. Army Corps of Engineers, 2006). Snowpack levels in the mountains of the South Platte River Basin were at 32 percent of their long-term averages in 2002 at the time of their typical peak levels in early to mid-April (Denver Water, 2004), and statewide precipitation levels in Colorado during July 2001 through June 2002 were at the lowest level of any single year since 1895 (National Oceanic and Atmospheric Administration, 2002a). Prolonged below-average precipitation statewide in Montana and Wyoming during this period resulted in values of the Palmer Drought Index - an index of the scope, severity, and frequency of protracted periods of abnormally dry or wet weather-during 2002 that were at the lowest level observed in 100 years (National Oceanic and Atmospheric Administration, 2002b). Drought conditions also persisted in the Central and Northern Plains States of Nebraska, North Dakota, and South Dakota during this period (National Oceanic and Atmospheric Administration, 2002b, 2003). Precipitation levels in Nebraska between December 2001 and July 2002 were at the lowest level since 1895 (National Oceanic and Atmospheric Administration, 2002b). By 2003, moderate to severe drought conditions were observed in parts of northwestern Missouri (National Oceanic and Atmospheric Administration, 2003). The widespread downward trends in streamflow indicate that drought conditions in the latter part of the study period were the predominant factor affecting streamflow throughout the Missouri River Basin.

Two upward trends in streamflow were observed (fig. 3, Appendix 3). Both trends were small relative to the reference streamflow values. At site 28 , streamflow was regulated in part by a reservoir approximately $18 \mathrm{~km}$ upstream, and releases from the reservoir likely offset the effects of the drought on streamflow. At site 39, much of the streamflow was derived from ground-water inflow. Typically, it takes longer for drought effects to be seen in ground water than in surface water. This may not always be the case; during a drought, increased irrigation can lead to more return flow, or increased dependence on ground water for domestic and municipal water supplies can increase ground-water withdrawals. Site 39, however, was largely unaffected by irrigation or withdrawals for water supply. There were no significant trends in streamflow at six sites (fig. 3, Appendix 3). Streamflow at each of these sites was affected either by upstream water management (reservoir releases or transbasin diversions) or derived in large part from ground-water inflow.

\section{Trends from 1985 to 2003}

Streamflow varied seasonally and annually but generally decreased at the subset of sites used in the analysis of trends from 1985 to 2003 (fig. 4). At several sites, a general pattern of decreasing streamflow occurred from about 1985 to about 1991, followed by increasing streamflow from about 1992 to about 1996 and decreasing streamflow from about 1997 to about 2003. For many of the sites, the decrease in streamflow during the latter part of trend period (from about 1997 to 2003) was substantially larger than the increases observed from about 1992 to 1996 . This likely contributed to the downward monotonic trends detected during the seasonal Kendall analysis of streamflow data from 1993 to 2003.

\section{Nitrogen}

\section{Trends from 1993 to 2003}

\section{Total Nitrogen}

From 1993 to 2003, there were nonsignificant FA trends in TN concentrations at 13 of 19 sites (fig. 5B, Appendix 4). This finding indicates that at the majority of sites, pollutioncontrol strategies or other human activities were not contributing to a measurable change in $\mathrm{TN}$ concentrations. There were upward trends at four sites where human activities may have contributed to increasing TN concentrations. Pollution-control strategies or other human activities may have contributed to significant decreases in TN concentrations at only 2 of 19 sites. Three of the four upward trends were in Nebraska, and there were nonsignificant trends at seven of the eight sites (both tributary and main-stem sites) in Missouri.

From 1993 to 2003, there were nonsignificant NFA trends in TN concentrations at 12 of 19 sites (fig. 5A, Appendix 5). There were upward trends at two sites; at these sites, a combination of natural and (or) human factors likely was leading to increases in TN concentrations. Downward trends in overall TN concentrations were observed at 5 of 19 sites. Four of the five downward trends were in Missouri.

There was no consistent pattern in the combination of FA, NFA, and streamflow trends at each site. At four sites, there were nonsignificant FA and NFA trends in TN concentrations, even though there was a downward trend in streamflow. In 


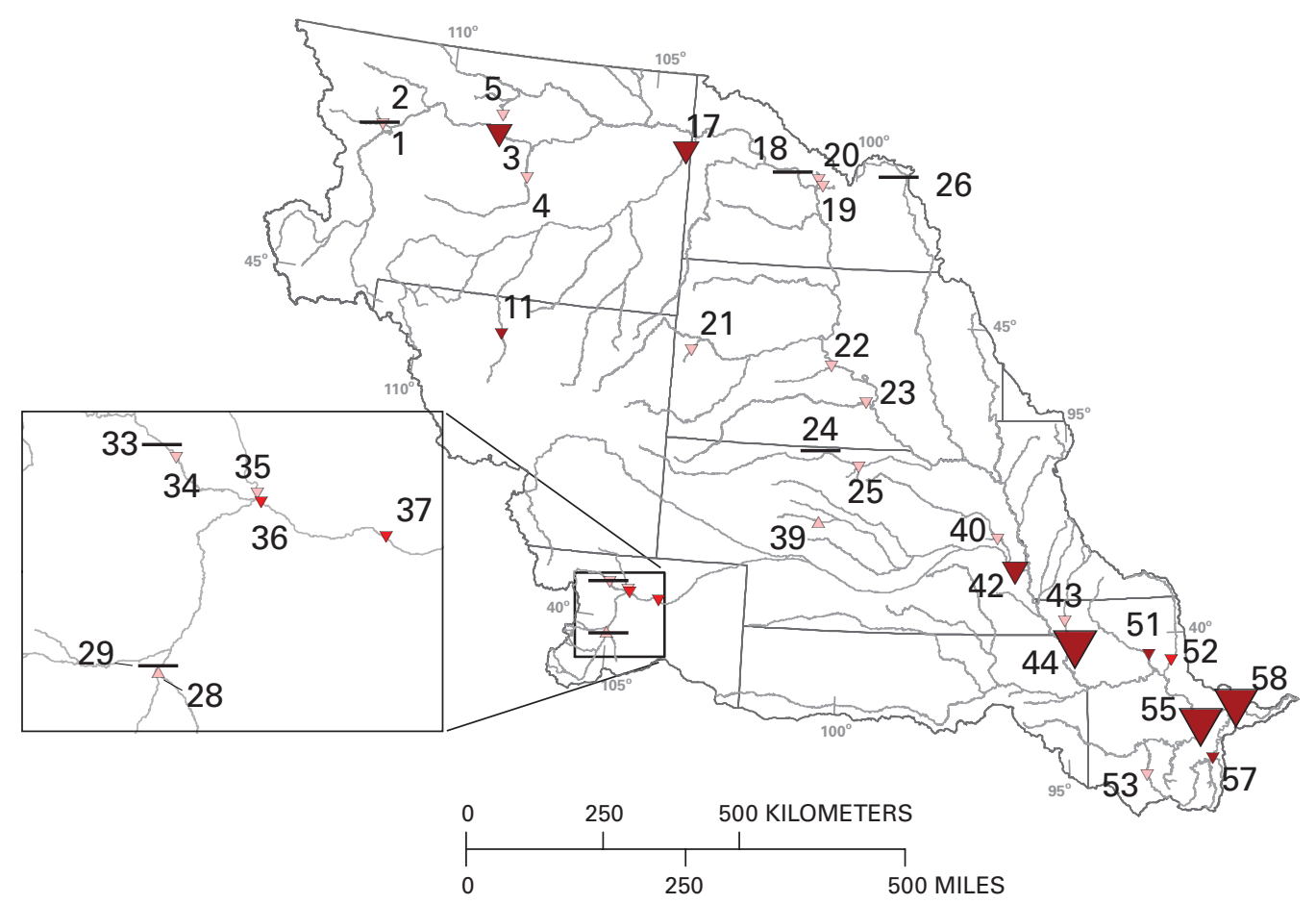

EXPLANATION

Direction of trend

$\triangle$ Upward

$\nabla$ Downward

- No significant change

Numbers are site numbers used in tables and appendixes
Magnitude of trend, in cubic meters per second per year

$$
\triangle \bigvee \text { Greater than or equal to } 22.7
$$

$\begin{array}{cc}\triangle \nabla & 11.4-22.6 \\ \triangle \nabla & 0-11.3\end{array}$
Reference streamflow, in cubic meters per second Greater than or equal to 22.7

$11.4-22.6$

$0-11.3$

Figure 3. Trends in streamflow from 1993 to 2003 at selected locations in the Missouri River Basin. 
these cases, the downward trend in streamflow apparently had no measurable effects on concentration; this may be because concentrations were affected by factors unrelated to streamflow. This relation also may have been because any decreases in concentration resulting from decreased loading from nonpoint sources were offset by decreased dilution of loading from point sources. At three sites, there was an upward FA trend, a nonsignificant NFA trend, and a downward trend in streamflow. In these cases, the upward FA trend indicates that overall concentrations would have been higher without the decrease in streamflow and the associated decrease in surface runoff to the stream. At three other sites, there was a nonsignificant FA trend, a downward NFA trend, and a downward trend in streamflow. In these cases, there is no evidence that pollution-control strategies or other human activities were contributing to a change in TN concentrations. The decrease in overall concentrations appears to be related to decreasing surface runoff associated with decreasing streamflow; without this decrease in surface runoff, overall concentrations may not have decreased significantly.

\section{Nitrite Plus Nitrate}

From 1993 to 2003, there were more downward trends in NOX concentrations than there were in TN concentrations. There were downward FA trends in NOX concentrations at 10 of 24 sites (fig. 5C, Appendix 4); this indicates that at many sites, pollution-control strategies or other human activities were contributing to a measurable decrease in NOX concentrations. However, at the other 14 sites, there was no FA trend in NOX concentrations; at those sites, pollution-control strategies or other human activities were not contributing to a measurable change in NOX concentrations. There were no upward trends at any of the sites.

From 1993 to 2003, there were nonsignificant NFA trends in NOX concentrations at 13 of 24 sites (fig. 5D, Appendix $5)$. This indicates that at more than one-half of the sites, overall NOX concentrations (affected by any and all factors in the upstream basin) did not change significantly during this period. Significant decreases occurred at nearly as many sites; downward NFA trends in NOX concentrations were observed at 10 of 24 sites. There was an upward NFA trend in NOX concentrations at only one site. At this site, there was a nonsignificant FA trend, indicating that decreasing streamflow and the associated decrease in in-stream dilution capacity were contributing to the upward NFA trend at the site.

There was no consistent pattern in the combination of FA, NFA, and streamflow trends at each site, but as with $\mathrm{TN}$ the most frequent combination observed (7 of 24 sites) was a nonsignificant FA and NFA trend in NOX concentrations and a downward trend in streamflow. In these cases, the downward trend in streamflow apparently had no measurable effects on concentration; this may be because concentrations were affected by factors unrelated to streamflow. This also may be because any decreases in concentration resulting from decreased loading from nonpoint sources were offset by decreased dilution of loading from point sources. However, it also may be in part a result of changes in ground-water inflow; with streamflow decreasing at these sites, the total flow likely was derived in greater part from ground-water inflow. Because of the time required for ground water to travel to streams, there may be a lag time between the implementation of some pollution-control strategies and improvement in stream quality; this lag time, which may range from days to decades (Lindsey and others, 2003), could have contributed to the nonsignificant trends in NOX concentrations from 1993 to 2003. More information on ground-water contributions to surface-water nitrate trends is presented in the section "Effect of Ground Water on Surface-Water Nitrate Trends.”

\section{Ammonia}

From 1993 to 2003, there were downward FA trends in NH3 concentrations at 15 of 23 sites (fig. 5E, Appendix 4). This indicates that at more than one-half of the sites, pollutioncontrol strategies or other human activities were contributing to decreasing NH3 concentrations. There were no upward FA trends. The downward and nonsignificant FA trends were distributed throughout the basin. In Missouri, there were downward FA trends at five of the six sites (both tributary and main-stem sites).

From 1993 to 2003, there were downward NFA trends in NH3 concentrations at 18 of 23 sites (fig. $5 F$, Appendix 5). At most of the sites, overall NH3 concentrations (affected by any and all factors in the upstream basin) decreased significantly during this period. There was an upward NFA trend in NH3 concentrations at only one site (site 36). As with TN and NOX at this site, there was a nonsignificant FA trend, indicating that decreasing streamflow and the associated decrease in instream dilution capacity likely was the main contributor to the upward NFA trend in NH3 concentrations at the site. As with the FA trends, the downward and nonsignificant NFA trends were distributed throughout the basin, and there were downward NFA trends at all of the sites in Missouri.

The combination of FA, NFA, and streamflow trends at each site most frequently observed (11 of 23 sites) was downward FA, NFA, and streamflow trends. At these sites, the downward FA trend indicates that pollution-control strategies and other human activities were contributing to a measurable decrease in concentrations of NH3. The downward FA trends were greater in magnitude than the downward NFA trends, indicating that although increased concentrations from decreased dilution may have been offsetting decreases resulting from pollution-control strategies and other human activities, these increases were not great enough to prevent downward NFA trends.

\section{Changes in Nutrient Sources and Landscape Characteristics from 1993 to 2003}

From 1993 to 2003, the largest source of nitrogen loading on the land surface in the Missouri River Basin most often was from fertilizer, followed by manure, atmospheric deposi- 

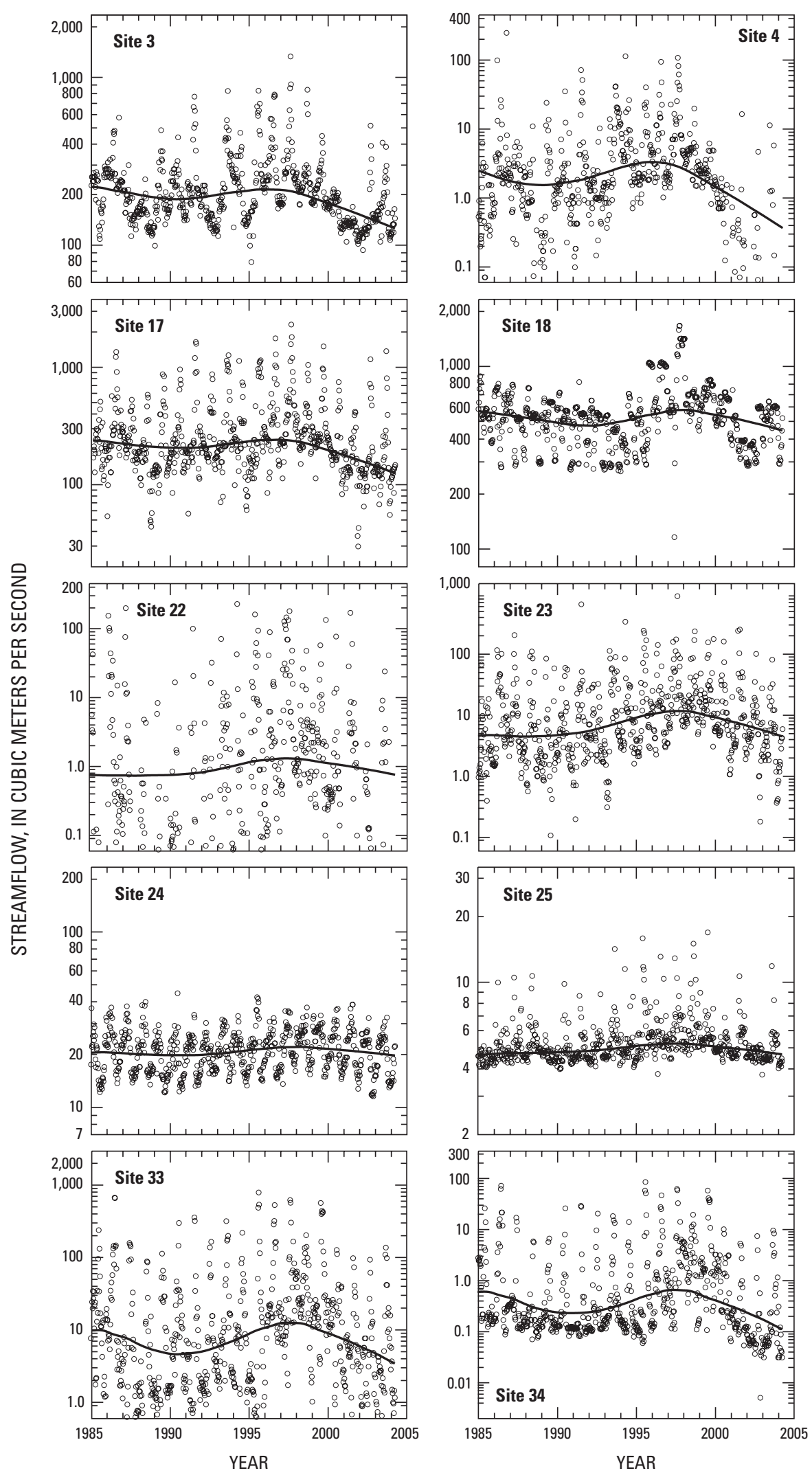

Figure 4. Graphs showing daily mean discharge at selected locations in the Missouri River Basin from 1985 to 2003, with a LOWESS curve. 

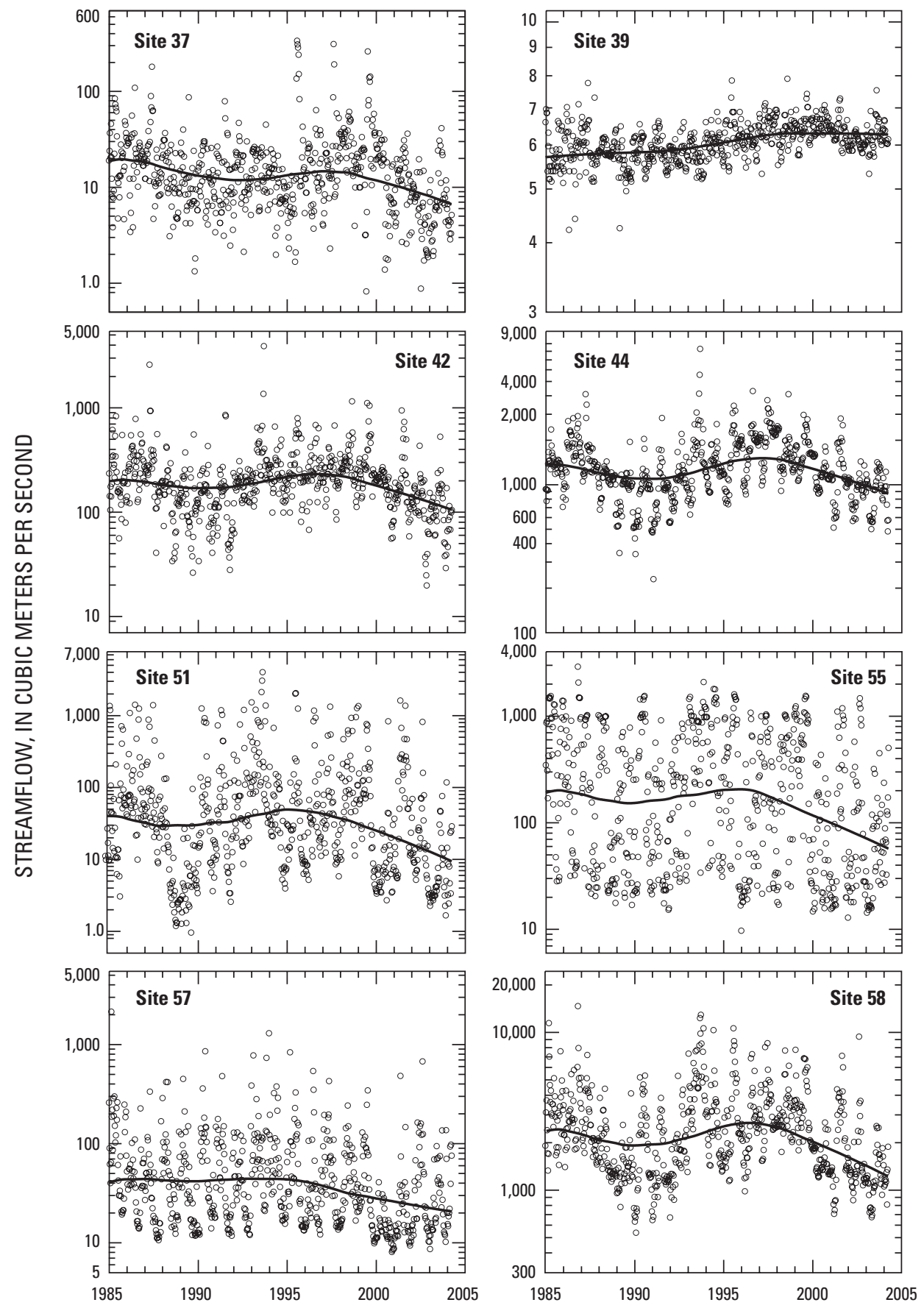

\section{EXPLANATION}

LOWESS curve

Daily mean discharge,

3 values per month

Figure 4. Graphs showing daily mean discharge at selected locations in the Missouri River Basin from 1985 to 2003, with a LOWESS curve.-Continued 
(A) Total Nitrogen

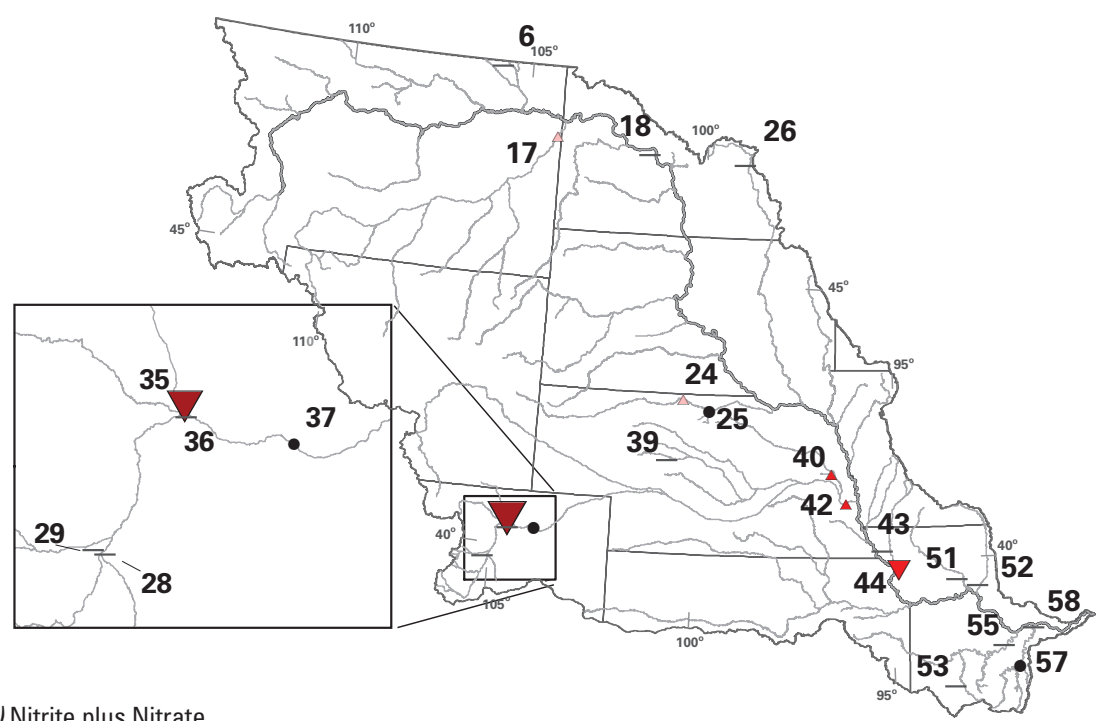

(C) Nitrite plus Nitrate

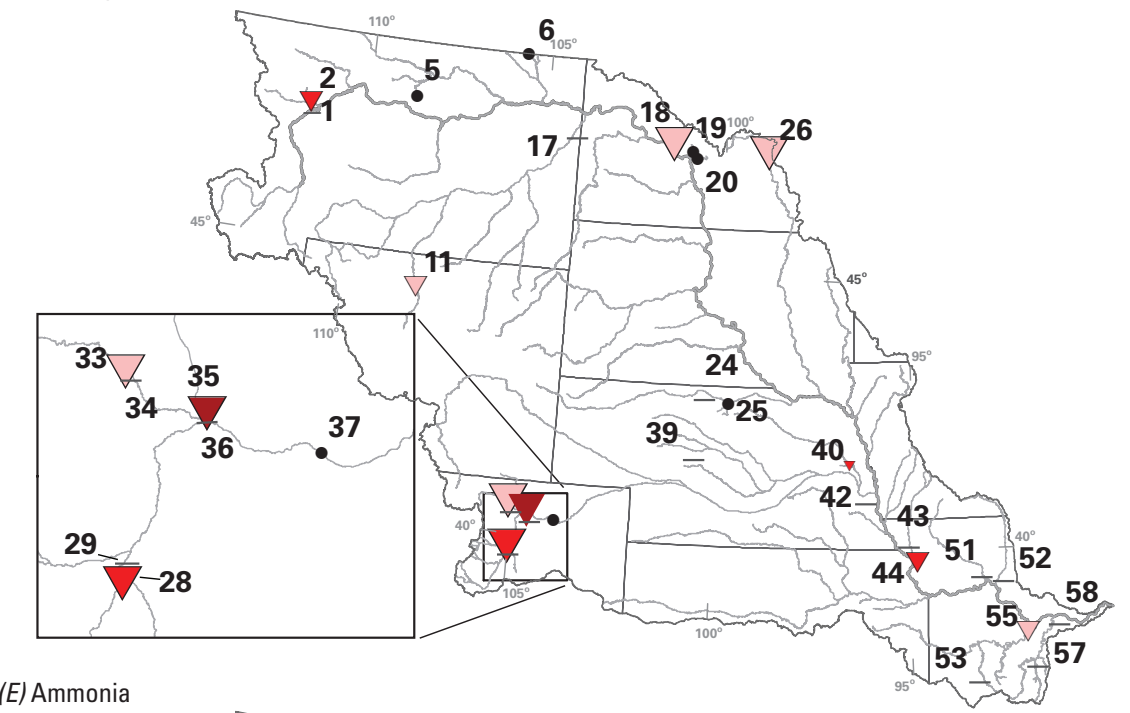

Ammonia

\section{EXPLANATION}

Flow-adjusted trend in concentration Direction of trend

$\triangle \quad$ Upward

$\nabla \quad$ Downward

- No significant change

- Model could not be fit to data

Numbers are site numbers used in tables and appendixes

Magnitude of trend, in percent per year

$\triangle \nabla$ Greater than or equal to 10

$\Delta \nabla \quad 5.00-9.99$

$\Delta \nabla \quad 0.00-4.99$

Reference concentration, in milligrams per liter Total Nitrogen Nitrite plus Nitrate Ammonia

$\begin{aligned} & \text { Greater than } \\ & \text { or equal to } 10\end{aligned}$
or equal to 5 $\quad \begin{aligned} & \text { Greater than } \\ & \text { or equal to } 0.2\end{aligned}$

$3.0-9.9$

$0.0-2.9$

$1.0-4.9$

$0.0-0.9$

$0.05-0.19$

$0.0-2.9$

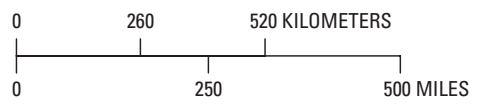

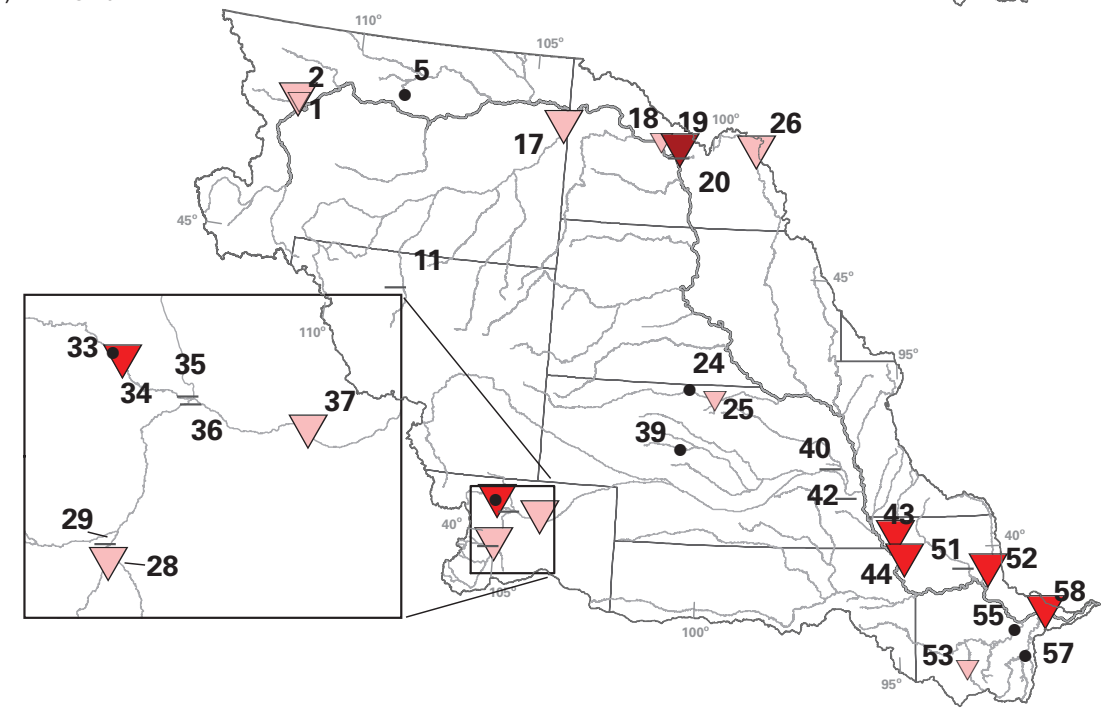

Figure 5. Flow-adjusted and non-flow-adjusted trends in concentration of $(A, B)$ total nitrogen, $(C, D)$ nitrite plus nitrate, and $(E, F)$ ammonia from 1993 to 2003 at selected locations in the Missouri River Basin. 
(B) Total Nitrogen

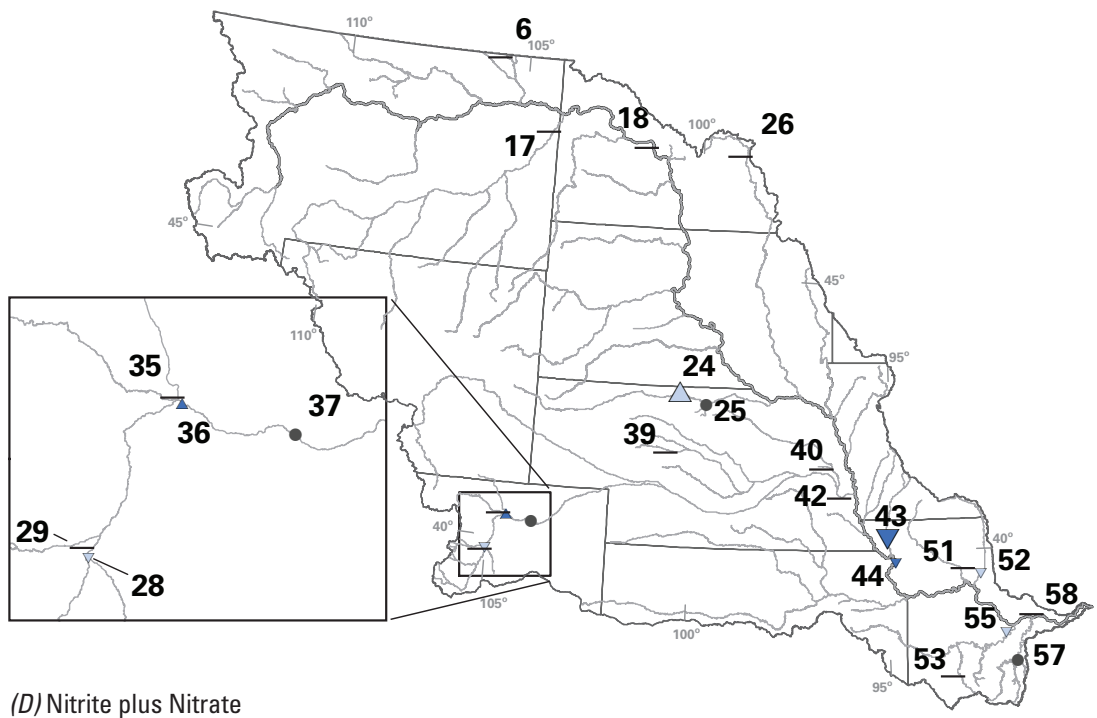

(D) Nitrite plus Nitrate
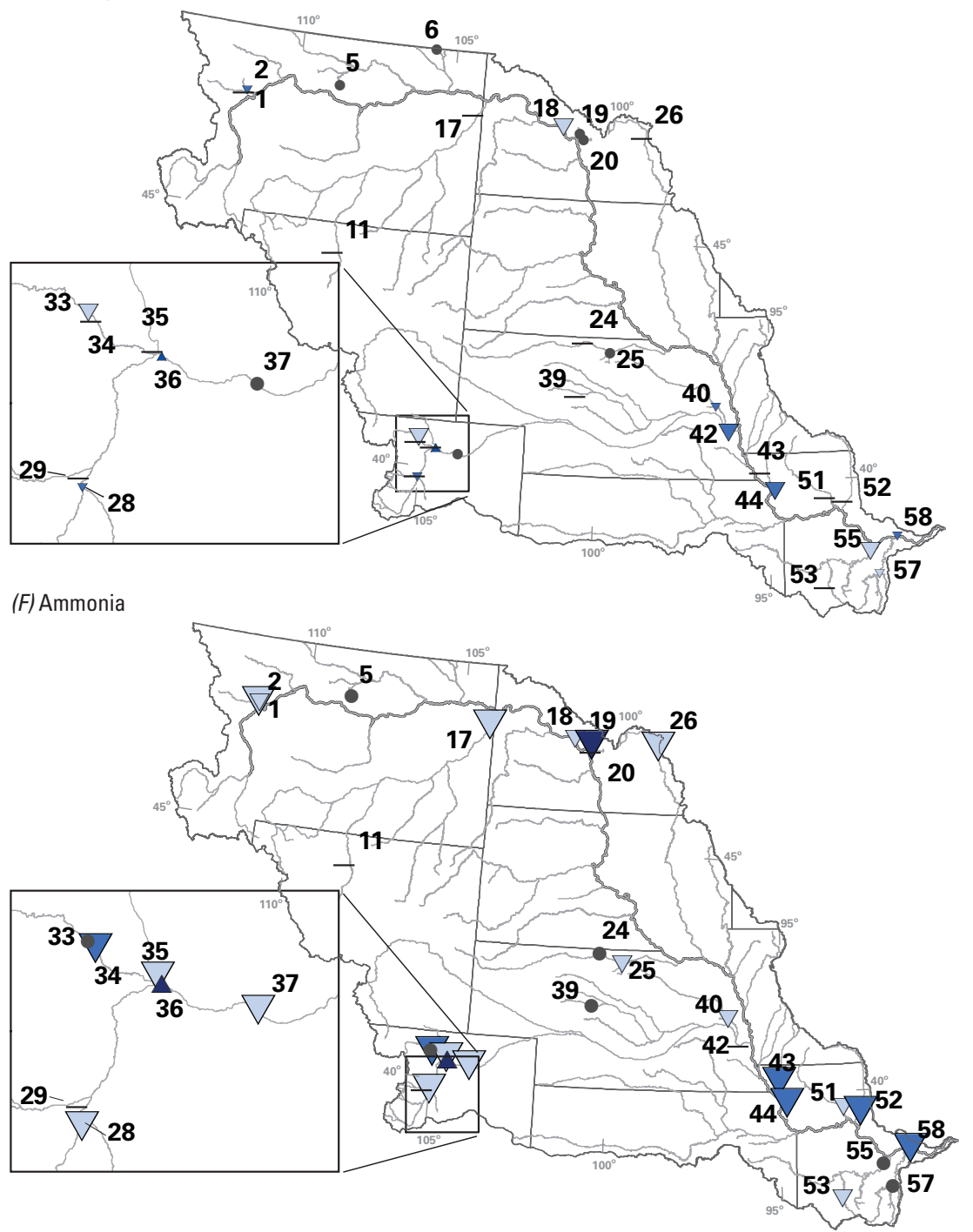

\section{EXPLANATION}

Non-flow-adjusted trend in concentration Direction of trend

$\triangle \quad$ Upward

$\nabla \quad$ Downward

- No significant change

- Model could not be fit to data Numbers are site numbers used in tables and appendixes

Magnitude of trend, in percent per year

$\begin{array}{ll}\triangle \nabla & \text { Greater than or equal to } 10 \\ \triangle \nabla & 5.00-9.99 \\ \Delta \nabla & 0.00-4.99\end{array}$

Reference concentration, in milligrams per liter Total Nitrogen Nitrite plus Nitrate Ammonia

Greater than
or equal to 10 $\begin{aligned} & \text { Greater than } \\ & \text { or equal to } 5\end{aligned} \quad \begin{aligned} & \text { Greater than } \\ & \text { or equal to } 0.2\end{aligned}$

$3.0-9.9$

$0.0-2.9$

$1.0-4.9$

$0.0-0.9$

$0.05-0.19$

$0.0-0.049$

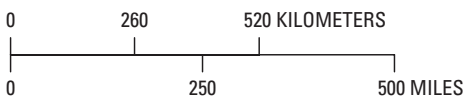

Figure 5. Flow-adjusted and non-flow-adjusted trends in concentration of $(A, B)$ total nitrogen, $(C, D)$ nitrite plus nitrate, and $(E, F)$ ammonia from 1993 to 2003 at selected locations in the Missouri River Basin.-Continued 
tion, and point sources. There were small areas where manure, atmospheric deposition, or point sources were a larger source. Fertilizer loads deceased between 1993 and 2003 at only about one-half of the sites, which may have contributed to the small number of downward trends in nitrogen.

No strong relations were identified through the weighted least-squares regression analysis of nitrogen trends and changes in nutrient sources and landscape characteristics (figs. 6, 7, and 8). There were weak relations between the magnitude of the NFA trend in NOX concentrations and changes in nitrogen loading from point sources in the full drainage area $\left(\mathrm{R}^{2}=0.31\right)$ (fig. 7) and between both the NFA and FA trends in $\mathrm{NH} 3$ concentrations and changes in nitrogen loading from point sources in the nearest 10-percent drainage area $\left(\mathrm{R}^{2}=0.36\right.$ and 0.43 , respectively) (fig. 8). Larger decreases in NOX and NH3 concentrations appeared to occur as point-source loading increased from 1993 to 2003, but this conclusion cannot be supported given the large number of data points with a change in point-source loading of zero. In addition, there was a weak relation between the magnitude of the FA trend in NH3 concentrations and changes in the acreage in conservation practices in the nearest 10-percent drainage area $\left(\mathrm{R}^{2}=0.36\right)$. Larger decreases in $\mathrm{NH} 3$ concentrations appeared to occur as the acreage in conservation practices increased from 1993 to 2003; this weak relation was not observed with NFA trends.

The results of the weighted least-squares regression analysis indicate that none of the nutrient sources and landscape characteristics described trends in nitrogen concentrations basinwide. If trend results for more sites in the Missouri River Basin became available in the future, the sites could be stratified on the basis of factors such as major land use, stream size, or physiographic province that could limit variability among sites. Linkages between changes in nutrient sources and landscape characteristics and nitrogen trends might be stronger as a result.

\section{Effect of Ground Water on Surface-Water Nitrate Trends}

Base-flow contributions to streamflow varied substantially among the three case-study sites. Contributions ranged from 71 to 84 percent (mean of 79 percent) at site 1 , from 97 to 99 percent (mean of 98 percent) at site 39, and from 38 to 59 percent (mean of 43 percent) at site 53 . The amount of base-flow contributing to streamflow was related to the hydrogeologic characteristics of each basin. Contributions were highest at site 39 primarily because the permeable sandy soils promoted infiltration over surface runoff and were lowest at site 53 primarily because the red clay minimized infiltration to the subsurface.

The temporal variability in base-flow contributions to streamflow from 1993 to 2003 also differed among the three sites (fig. 9A). Previous research has indicated that base flow comprises a larger percentage of streamflow in dry years, whereas surface runoff comprises a larger percentage of streamflow in wet years (Bachman and others, 1998). This was consistent with the results at site 53, where the base-flow contribution to streamflow was highest in the driest years. Differences between wet and dry years were more difficult to discern at site 39, where streamflow consisted almost entirely of base flow every year. As a result, the small upward trend in streamflow from 1993 to 2003 generally was mirrored by a small increase in the base-flow contribution to streamflow during the same period. At site 1, there was a smaller difference between wet and dry years than at site 53, which may have been due to increases in irrigation and irrigation return flow during dry years at site 1 .

Base-flow contributions to the surface-water NOX load also varied substantially among the three sites (Appendix 6). Base-flow contributions to the surface-water NOX load ranged from 70 to 94 percent (mean of 81 percent) at site 1 , from 94 to 111 percent (mean of 101 percent) at site 39 , and from 1 to 32 percent (mean of 17 percent) at site 53. (Note some contribution percentages exceeded 100 percent because of error in the load model.) These patterns were similar to the base-flow contributions to streamflow, indicating that base-flow contributions to the surface-water NOX load were greatest at sites where the base-flow contributions to streamflow were greatest.

The temporal variability in base-flow contributions to the surface-water NOX load from 1993 to 2003 also differed among the three sites and was related to the trends in streamflow and concentration at the sites (fig. 9B). At site 1, both base-flow and streamflow NOX loads generally decreased from 1993 to 2003. During this period, there was no trend in streamflow, but there were downward FA trends in NOX concentrations. This indicates that pollution-control strategies or other human activities were contributing to decreases in both base-flow and streamflow NOX loads. At site 39, base-flow and surface-water NOX loads generally did not change from 1993 to 2003. During this period, there was a small upward trend in streamflow but no FA trends in NOX concentrations. The land use in this basin is primarily rangeland (Frenzel and others, 1998), and pollution-control strategies may not have been implemented as frequently as in the more agriculturally intensive basin of site 1 . At site 53, base-flow and surfacewater NOX loads generally decreased from 1993 to 2003. During this period, there was a downward trend in streamflow but no FA trend in NOX concentrations. With little measurable contribution from pollution-control strategies, the downward trend in streamflow likely was the main contributor to the general decrease in surface-water NOX load. Drought conditions in the drainage area of site 53 during the latter half of the study period also may have contributed to a decrease in base flow (fig. 9A), which in turn may have contributed to a decrease in base-flow NOX loads as well.

The three case studies represent a range of ground-water contributions to streamflow and stream NOX loading in the Missouri River Basin. Although the conditions at site 39 may be unusual relative to areas outside of the Sand Hills, sites 1 and 53 are more representative of conditions encountered in other areas of the Missouri River Basin. Therefore, it is likely that a substantial portion of streamflow in other areas of the 
(A) Flow-adjusted trends

(B) Non-flow-adjusted trends

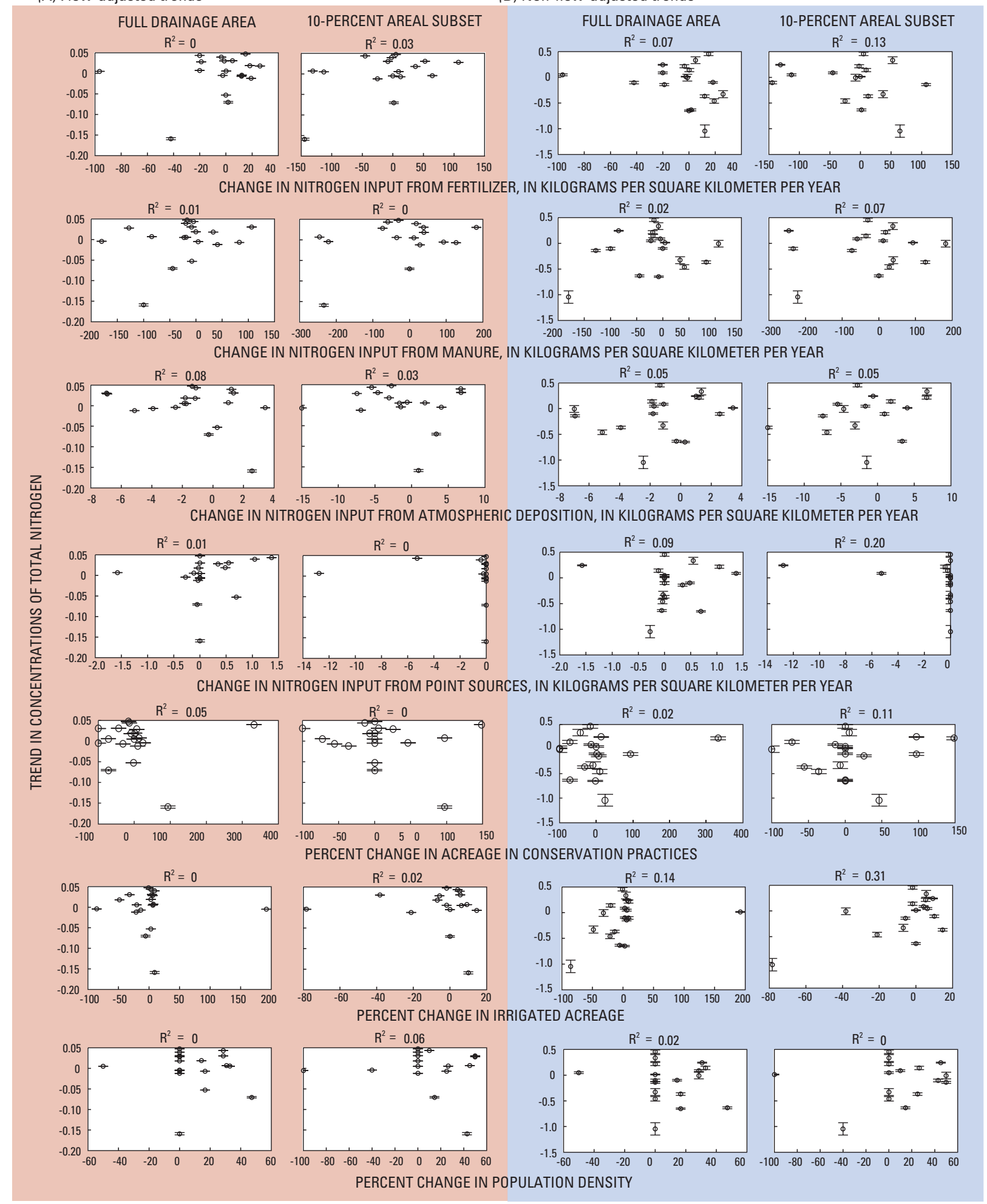

\section{EXPLANATION}

오 Error bars showing variance of the trend estimate

$\mathrm{R}^{2}$ Coefficient of determination

Figure 6. (A) Flow-adjusted and $(B)$ non-flow-adjusted trends in concentrations of total nitrogen compared to changes in nutrient sources and landscape characteristics from 1993 to 2003. 
(A) Flow-adjusted trends

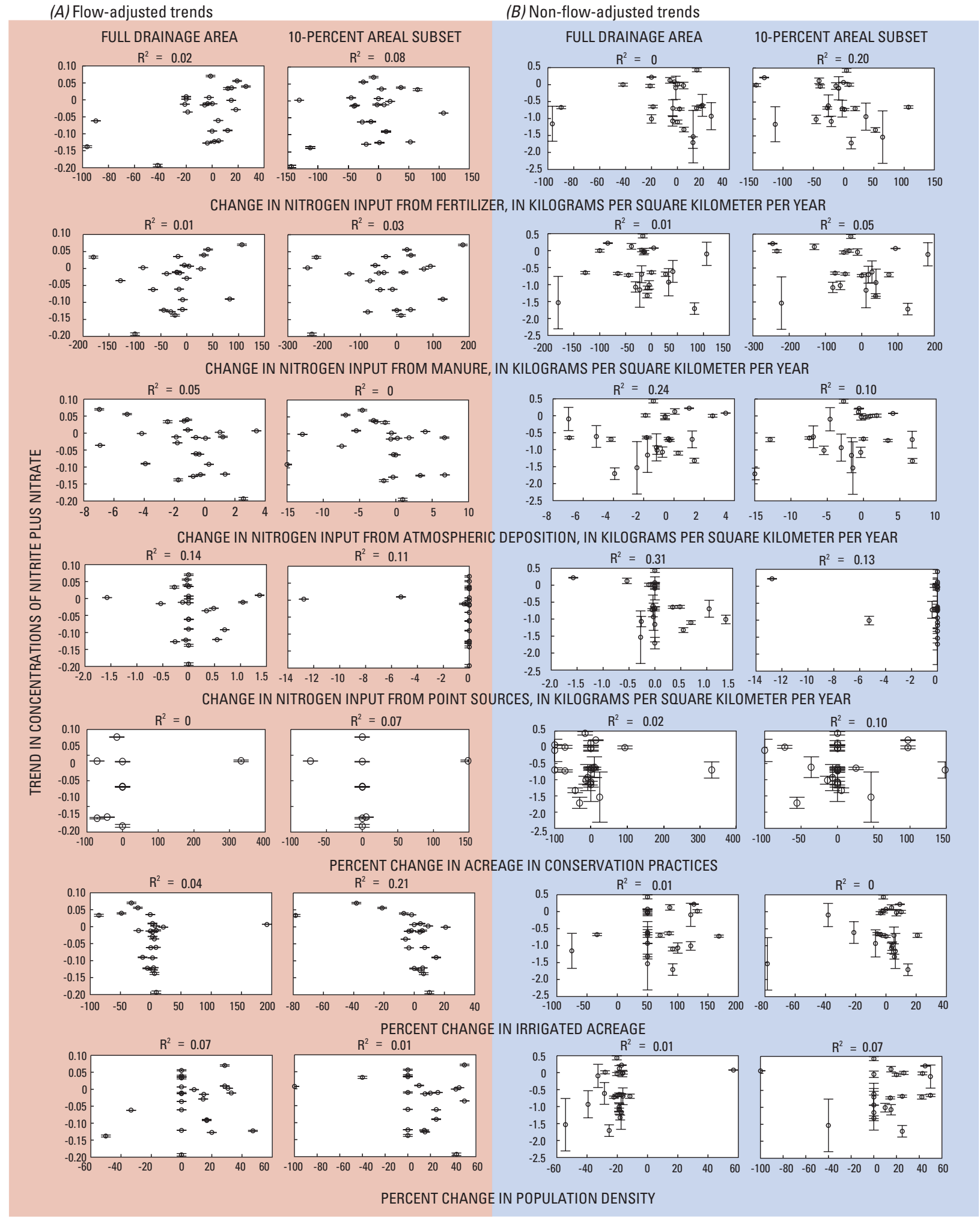

\section{EXPLANATION}

호 Error bars showing variance of the trend estimate $\quad R^{2}$ Coefficient of determination

Figure 7. ( $A$ ) Flow-adjusted and $(B)$ non-flow-adjusted trends in concentrations of nitrite plus nitrate compared to changes in nutrient sources and landscape characteristics from 1993 to 2003. 
(A) Flow-adjusted trends

(B) Non-flow-adjusted trends

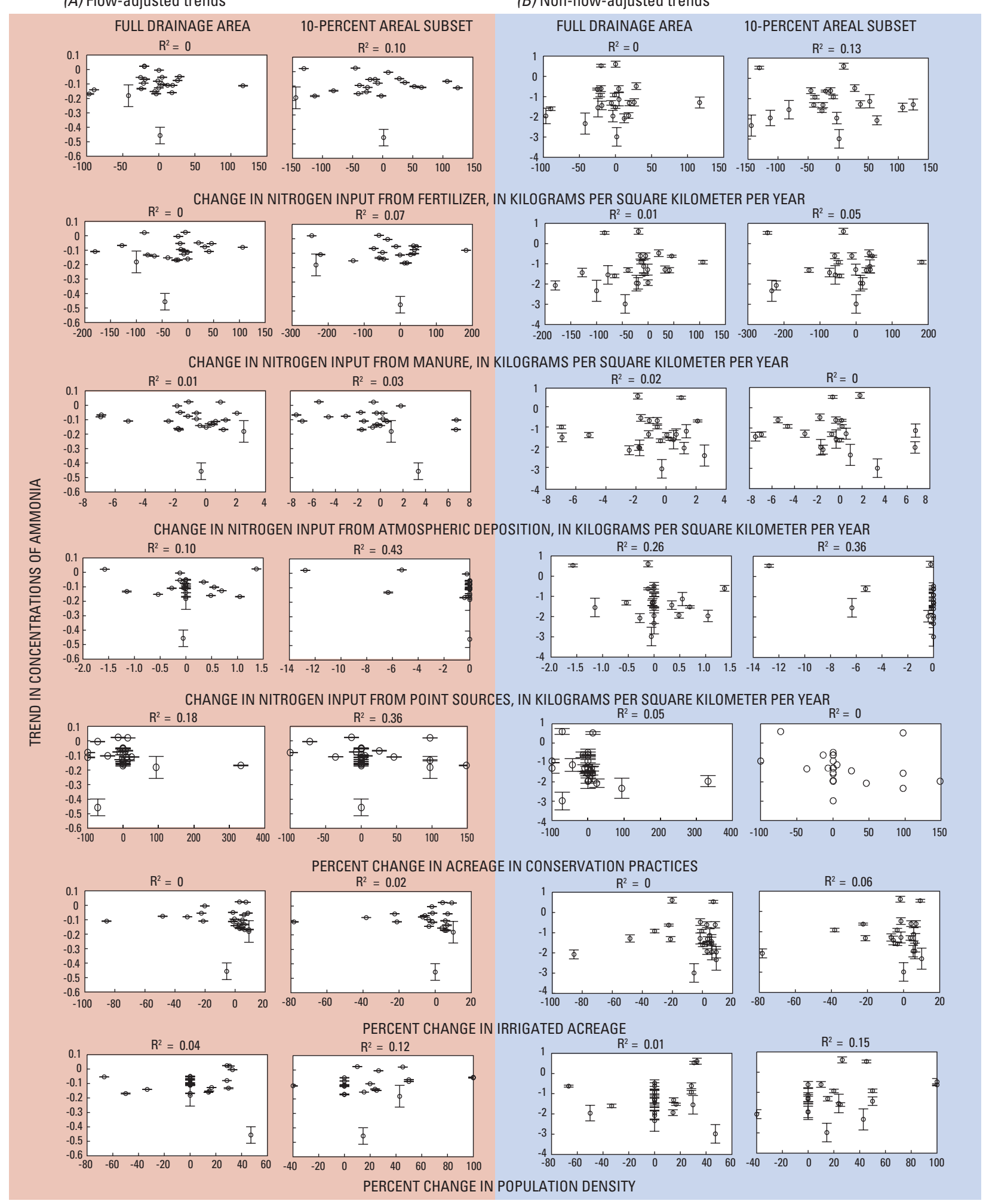

EXPLANATION

$\Phi$ Error bars showing variance of the trend estimate $\quad R^{2}$ Coefficient of determination

Figure 8. (A) Flow-adjusted and $(B)$ non-flow-adjusted trends in concentrations of ammonia compared to changes in nutrient sources and landscape characteristics from 1993 to 2003. 
(A)
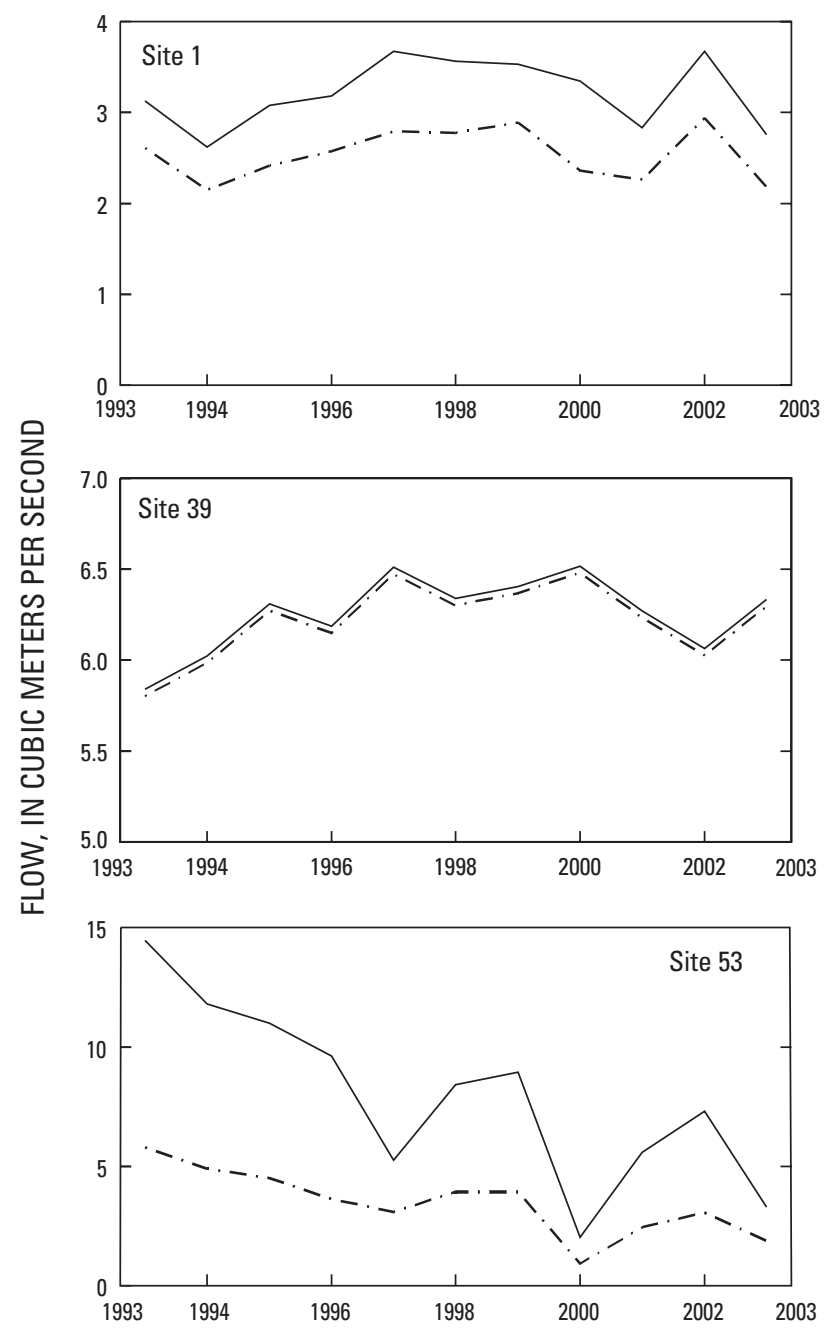

(B)
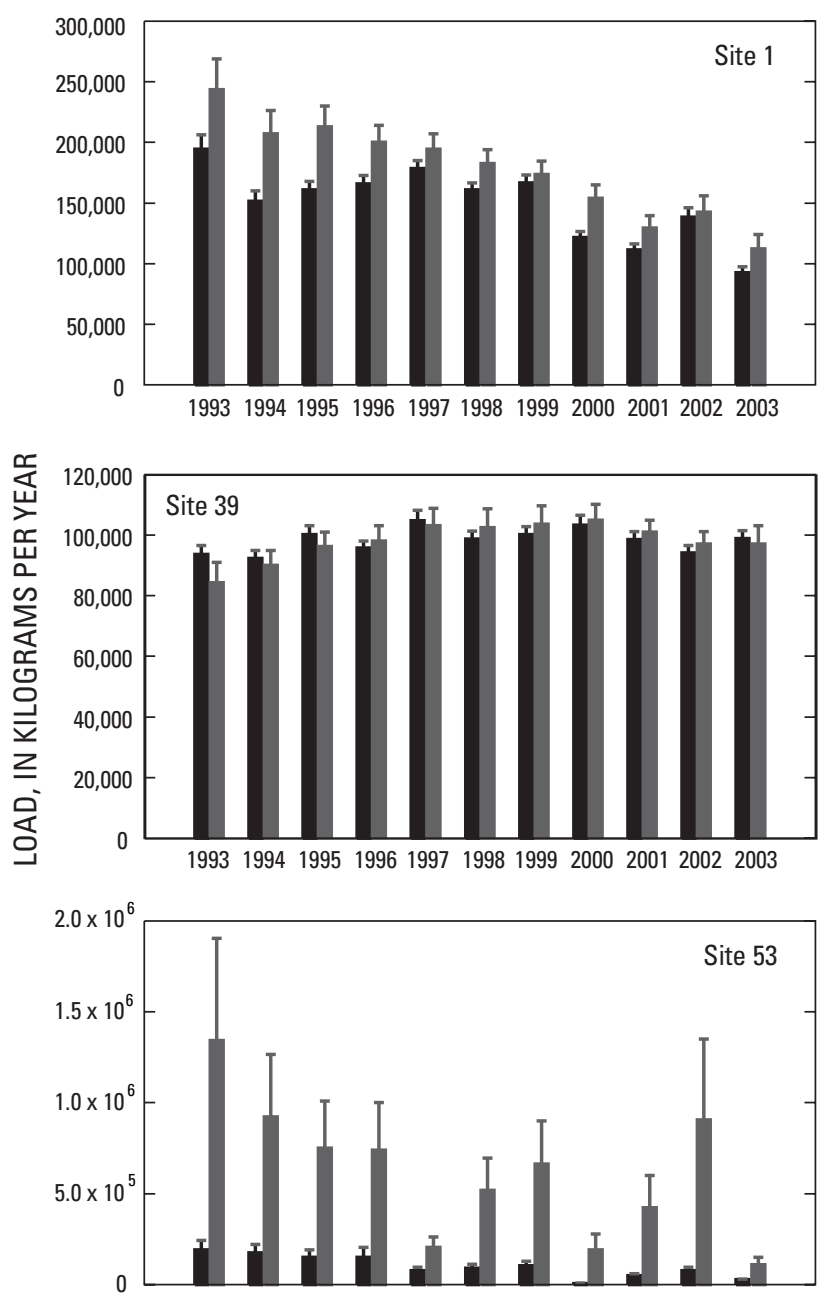

19931994199519961997199819992000200120022003

\section{EXPLANATION}

_ Total streamflow

- - Base flow

T Standard error of prediction

Nitrite-plus-nitrate load in base flow

Nitrite-plus-nitrate load in total streamflow

Figure 9. (A) Base-flow contribution to streamflow from 1993 to 2003 and $(B)$ total annual surface-water and base-flow loads of nitrite plus nitrite from 1993 to 2003 at three sites in the Missouri River Basin. Location of sites shown in figure 1. 
basin consists of base flow and that temporal changes in the base-flow contributions to streamflow and surface-water NOX loads likely had an effect on streamflow and in-stream concentration trends from 1993 to 2003 in those areas as well.

\section{Trends from 1985-2003}

\section{Total Nitrogen}

Significant FA trends in TN concentrations were detected at seven of nine sites at some point during the period from 1985 to 2003 (fig. 10, Appendix 7). Downward trends were detected at three sites (sites 18, 39, and 57), and upward trends were detected at two sites (sites 42 and 58). Two sites (sites 17 and 44) had increases and (or) decreases during multiple trend periods. The downward trends generally were detected for the earlier trend periods (1985 to 1991, 1985 to 1996, and 1992 to 1996), whereas the upward trends generally were detected for the later trend periods (1992 to 2003 and 1997 to 2003).

At site 17, a downward FA trend in TN concentrations was detected from 1985 to 1991 , followed by an upward trend from 1992 to 2003; an upward FA trend also was detected by the LOADEST program from 1993 to 2003. At site 42, an upward FA trend in TN concentrations was detected from 1997 to 2003; an upward FA trend also was detected using the LOADEST program from 1993 to 2003. The QWTREND model statistic was largest for the 1997 to 2003 time period, indicating that the data in the later part of the short-term trend period probably affected the LOADEST results and that a consistent monotonic FA trend may not have occurred over the entire period from 1993 to 2003. At sites 39 and 57, downward FA trends were detected from 1985 to 1991 . No trend model could be fit to the TN data at site 57 by the LOADEST program, so it is not possible to compare the trend results at that site. At sites 51 and 55, no FA trend was detected during the period from 1985 to 2003 . The results at sites 39, 51, and 55 are consistent the with the nonsignificant monotonic FA trends from 1993 to 2003 determined using LOADEST.

FA trends in TN concentrations from 1985 to 2003 varied at the three sites located on the main stem of the Missouri River (sites 18, 44, and 58). At site 18, a downward FA trend was detected from 1985 to 1996 . At site 44, a downward FA trend also was detected but only for the period from 1992 to 1996; this downward trend was followed by an upward trend from 1997 to 2003. At site 58, there was an upward FA trend from 1997 to 2003, which was consistent with the upward FA trend at site 44 . The trends at site 44 and site 58 are inconsistent with the monotonic FA trend results from 1993 to 2003; a downward trend at site 44 and a nonsignificant trend at site 58 were determined using the LOADEST program. The reason for this inconsistency between the trend methods is unknown. However, because TN concentrations generally decrease with decreasing streamflow at sites 44 and 58 and streamflow decreased at these sites from 1997 to 2003, it is possible that the LOADEST program did not remove all the streamflow- related variability. Reservoirs on the main stem of the Missouri River also may have complicated the streamflow and TN relations.

\section{Nitrite Plus Nitrate}

Significant FA trends in NOX concentrations were detected at all five sites sometime during the period from 1985 to 2003 (fig. 11, Appendix 7). Upward trends were detected at two sites (sites 25 and 39), and downward trends were detected at two sites (sites 33 and 34). One site (site 37) had increases and (or) decreases during multiple trend periods.

At sites 25 and 39, which are located on small streams in Nebraska, there were upward FA trends in NOX concentrations. The upward trend at site 25 occurred from 1985 to 1996 , and the upward trend at site 39 occurred from 1992 to 2003. No trend model could be fit for the NOX data at site 25 by the LOADEST program, so it is not possible to compare the results from LOADEST and QWTREND programs at that site. At site 39, a nonsignificant monotonic trend was found from 1993 to 2003 using the LOADEST program. This may indicate that the QWTREND program was able to remove more of the streamflow and concentration variability at this site than the LOADEST program, allowing the small magnitude FA trend to be detected.

There were downward FA trends in NOX concentrations from 1997 to 2003 at sites 33 and 34, which are both located on the Cache la Poudre River in Colorado. A monotonic downward FA trend was detected by the LOADEST program at site 33. The QWTREND model statistic was largest for the period from 1997 to 2003 at this site, indicating that the data in the later part of the short-term trend period probably affected the LOADEST results and that a consistent monotonic FA trend may not have occurred over the entire period from 1993 to 2003. The same was not true at site 34; a nonsignificant trend from 1993 to 2003 was found using the LOADEST program.

At site 37, there was a downward FA trend in NOX concentrations from 1985 to 1991 and an upward FA trend from 1997 to 2003. No trend model could be fit to the NOX data at this site by the LOADEST program, so it is not possible to compare the trend results.

\section{Phosphorus}

\section{Trends from 1993 to 2003}

\section{Total Phosphorus}

There were very few upward trends in the nitrogen constituents from 1993 to 2003. In contrast, 8 of 17 sites had upward FA trends in TP concentrations (fig. 12A, Appendix 4). This indicates that at nearly one-half of the sites, not only were pollution-control strategies not contributing to measurable decreases in TP concentrations, there was likely an 


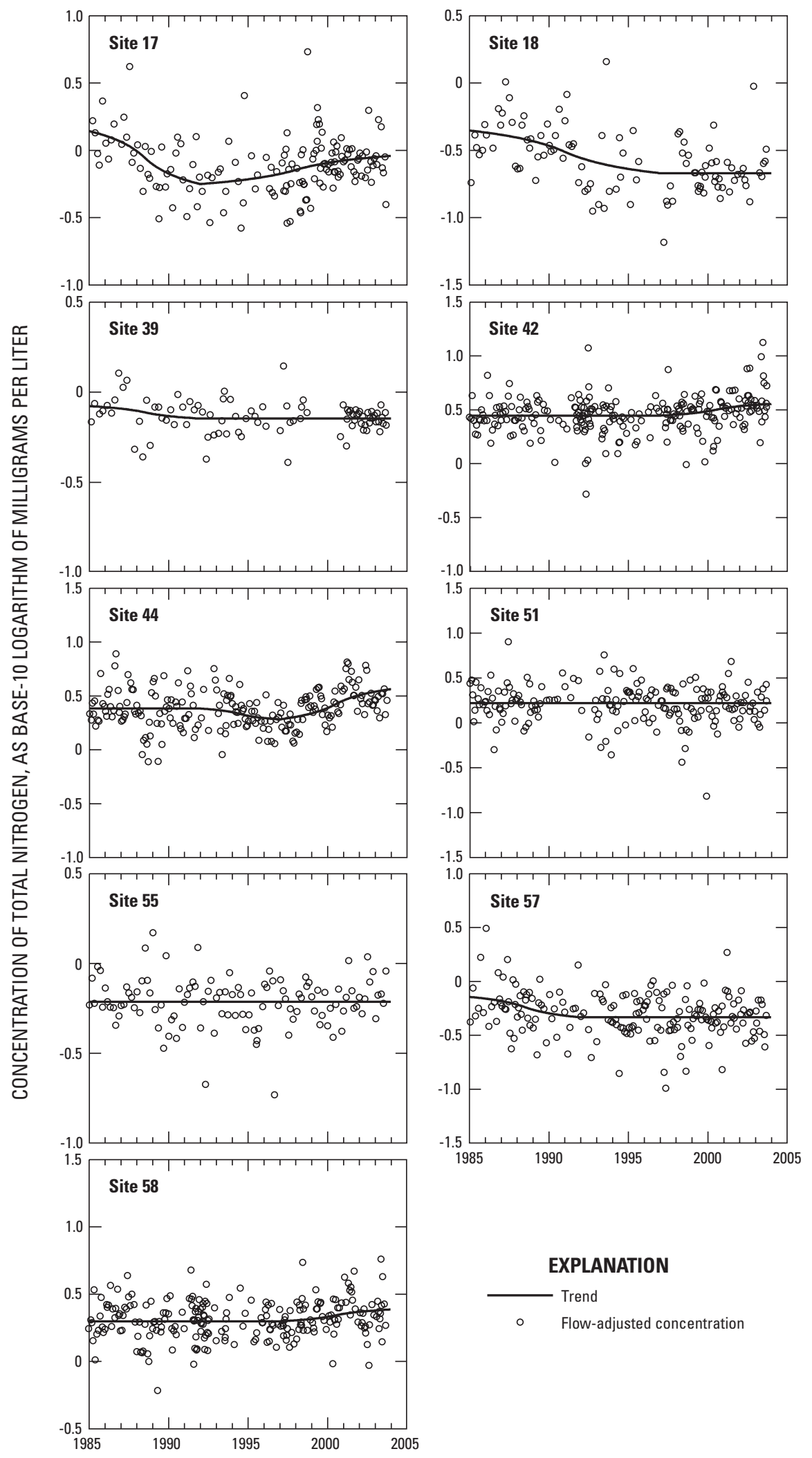

Figure 10. Flow-adjusted trends in concentrations of total nitrogen from 1985 to 2003. Location of sites shown in figure 1. 


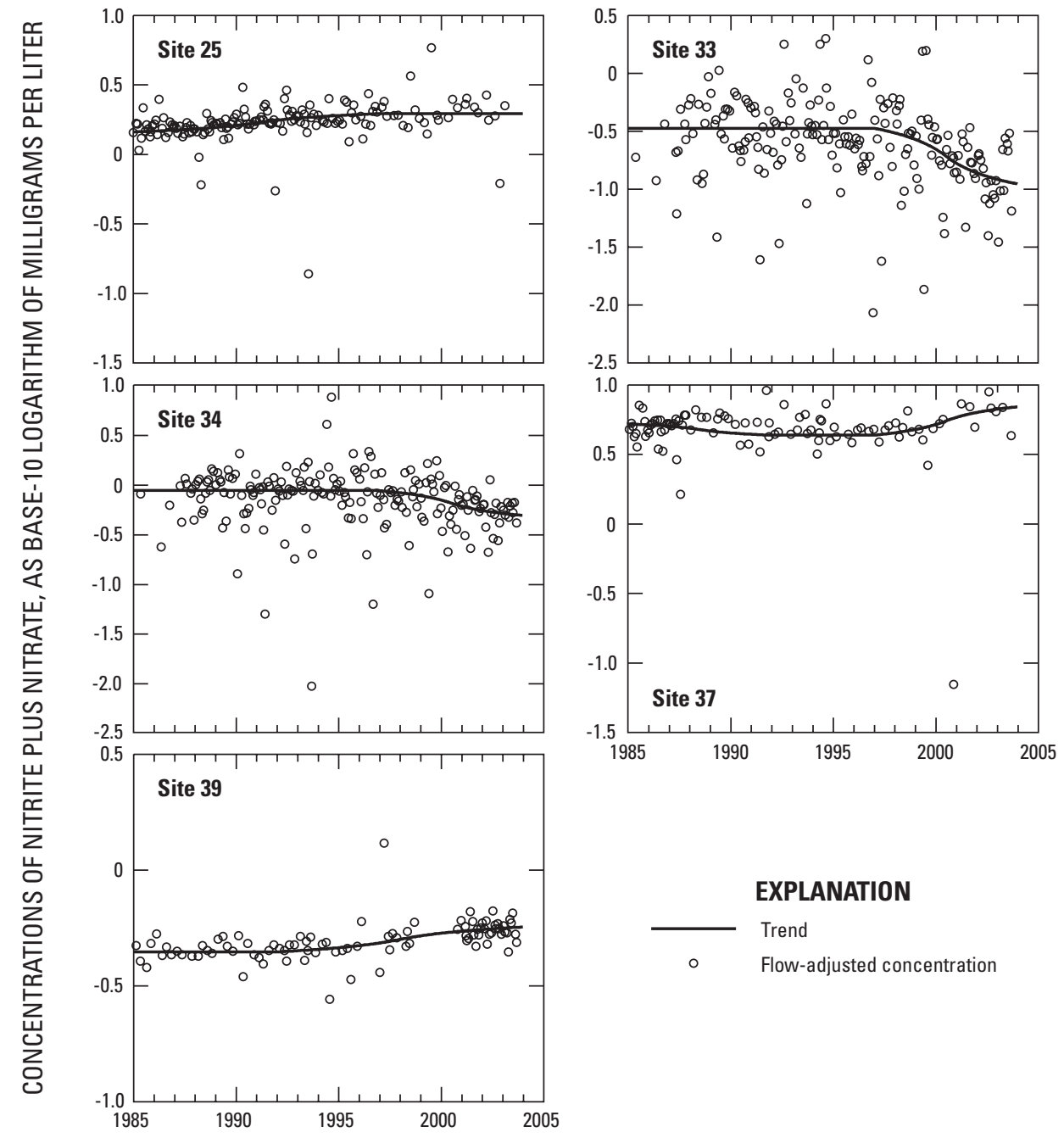

Figure 11. Flow-adjusted trends in concentrations of nitrite plus nitrate from 1985 to 2003. Location of sites shown in figure 1. 

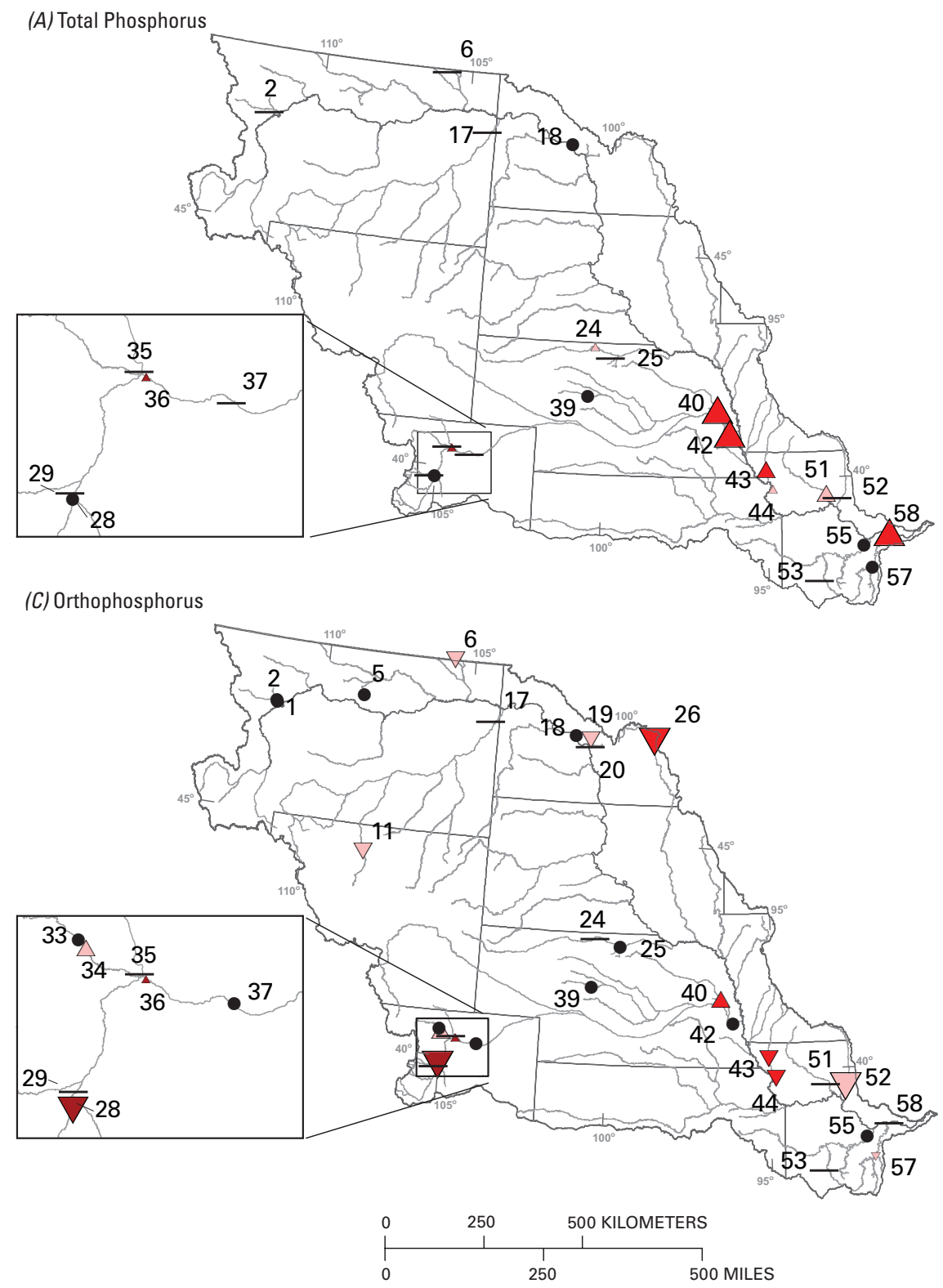

\section{EXPLANATION}

Flow-adjusted trend in concentration Direction of trend

$\triangle$ Upward

$\nabla$ Downward

$\checkmark$ No significant change

- Model could not be fit to data

Numbers are site numbers used

in tables and appendixes
Magnitude of trend, in cubic meters per second per year

$\triangle \nabla$ Greater than or equal to 10

$\triangle \nabla \quad 5.00-9.99$

$\Delta \nabla \quad 0-4.99$
Reference concentration, in milligrams per liter Total Phosphorus Orthophosphorus

$$
\text { Greater than Greater than }
$$$$
\text { or equal to } 0.5 \quad \text { or equal to } 0.2
$$$$
\begin{array}{lll}
0.2-0.49 & 0.1-0.19
\end{array}
$$

$0-0.19 \quad 0-0.09$

Figure 12. Flow-adjusted and non-flow-adjusted trends in concentrations of $(A, B)$ total phosphorus and $(C, D)$ orthophosphorus from 1993 to 2003 at selected locations in the Missouri River Basin. 
(B) Total Phosphorus

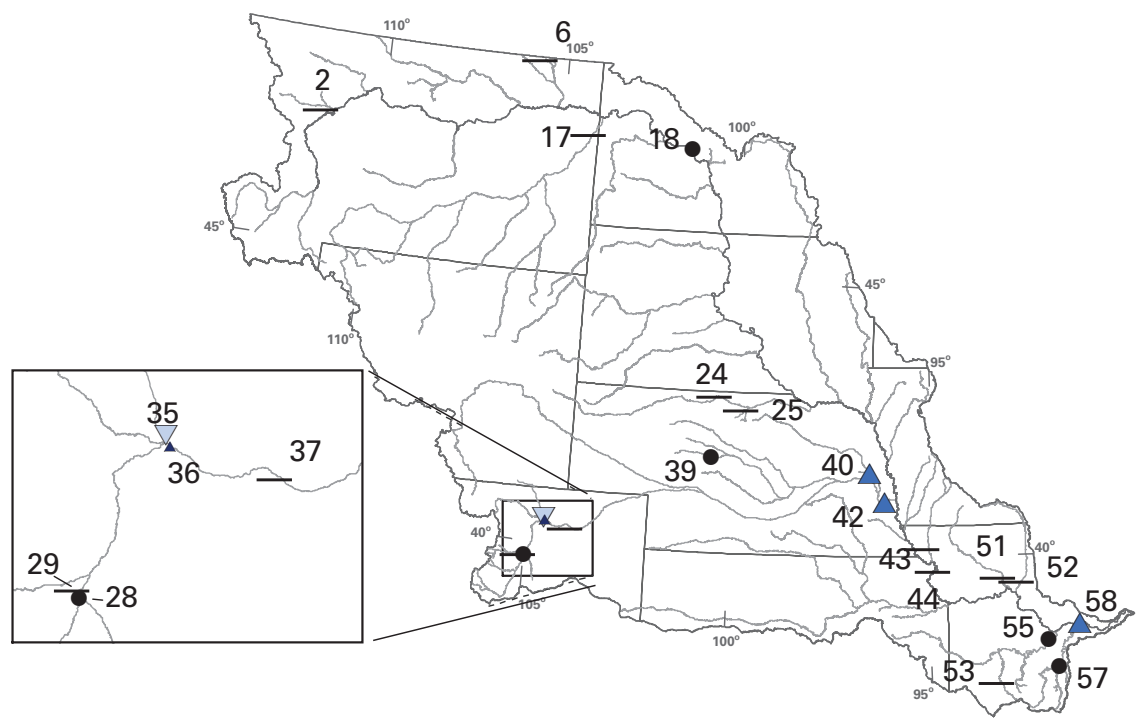

(D) Orthophosphorus

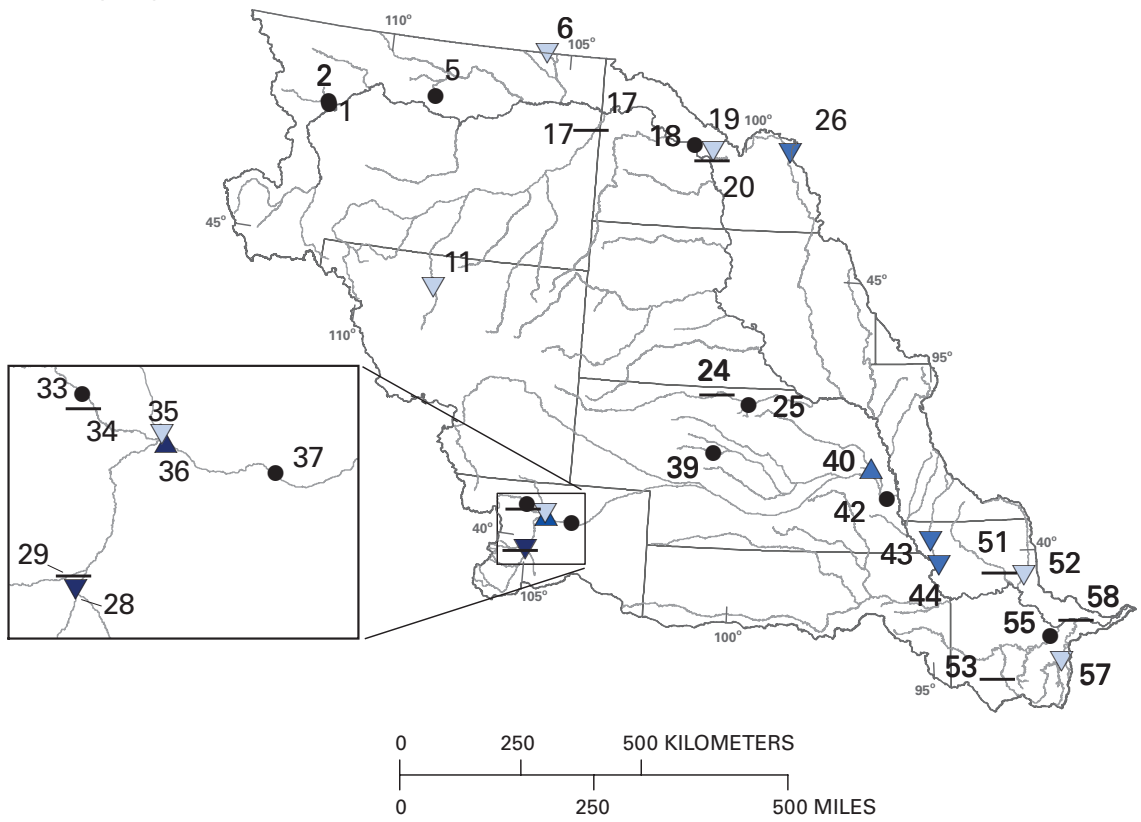

EXPLANATION

Non-flow-adjusted trend in concentration Direction of trend

Magnitude of trend, in percent per year

Reference concentration, in milligrams per liter

$\triangle$ Upward

$\nabla$ Downward

- No significant change

$\triangle \sqrt{ }$ Greater than or equal to 10

Total Phosphorus

Orthophosphorus

- Model could not be fit to dat

$\triangle \nabla \quad 5.00-9.99$

$\Delta \nabla \quad 0-4.99$

Greater than
or equal to 0.5

Greater than

$0.2-0.49$

Numbers are site numbers used

in tables and appendixes

Figure 12. Flow-adjusted and non-flow-adjusted trends in concentrations of $(A, B)$ total phosphorus and $(C, D)$ orthophosphorus from 1993 to 2003 at selected locations in the Missouri River Basin.-Continued 
increase in phosphorus loading on the land surface. There were no downward FA trends in TP concentrations.

From 1993 to 2003, there were fewer significant NFA trends than FA trends in TP concentrations, with upward NFA trends at 4 of 17 sites (fig. 12B, Appendix 5). At 12 of 17 sites, there were nonsignificant NFA trends in TP concentrations. At the majority of sites, overall TP concentrations (affected by any and all factors in the upstream basin) did not change significantly during this period. There was a downward NFA trend in TP concentrations at only one site.

There was no consistent pattern in the combination of FA, NFA, and streamflow trends at each site. At six sites, there were nonsignificant FA and NFA trends in TP concentrations, even though there was a downward trend in streamflow. In these cases, the downward trend in streamflow apparently had no measurable effects on concentration; this may be because concentrations were affected by factors unrelated to streamflow. It also is possible that decreases in concentration resulting from decreased loading from nonpoint sources were offset by decreased dilution of loading from point sources. At four sites, there were upward FA and NFA trends in TP concentrations and a downward trend in streamflow. In these cases, the FA increases likely were great enough to offset decreases in streamflow and the associated decrease in surface runoff to the stream, leading to NFA increases as well. At three other sites, there was an upward FA trend in TP concentrations, a nonsignificant NFA trend, and a downward trend in streamflow. In these cases, the upward FA trend indicated that overall concentrations would have been higher without the decrease in streamflow and the associated decrease in surface runoff to the stream. It is possible that at these three sites, the FA increase was not great enough to offset the decrease in streamflow, as was seen in the previous group of sites.

\section{Orthophosphorus}

From 1993 to 2003, there were fewer upward and more downward FA trends in OP concentrations than there were in TP concentrations. Upward FA trends in OP concentrations were detected at 3 of 20 sites (fig. 12C, Appendix 4). Downward FA trends occurred at 9 of 20 sites, indicating that at many sites, pollution-control strategies or other human activities were contributing to a measurable decrease in OP concentrations, which was not evident in the FA trends in TP concentrations. At 8 of 20 sites, there were nonsignificant FA trends in OP concentrations; at those sites, there were no measurable effects from pollution-control strategies or other human activities.

From 1993 to 2003, there were downward NFA trends in OP concentrations at 10 of 20 sites (fig. 12D, Appendix 5). This indicates that at one-half of the sites, overall OP concentrations (affected by any and all factors in the upstream basin) decreased significantly during this period. At nearly as many sites (8 of 20), nonsignificant NFA trends in OP concentrations occurred. There were upward NFA trends in OP concentrations at only two sites.
The combination of FA, NFA, and streamflow trends at each site most frequently observed (6 of 20 sites) was downward FA, NFA, and streamflow trends. At these sites, the downward FA trend indicated that pollution-control strategies and other human activities were contributing to a measurable decrease in concentrations of OP. Almost all of the downward FA trends were greater in magnitude than the downward NFA trends, indicating that although increased concentrations from decreased dilution may have been offsetting decreases resulting from pollution-control strategies and other human activities, these increases were not great enough to prevent downward NFA trends. At five other sites, there were nonsignificant FA and NFA trends in OP concentrations, even though there was a downward trend in streamflow. In these cases, the downward trend in streamflow apparently had no measurable effects on concentration; this may be because concentrations were affected by factors unrelated to streamflow. It also is possible that decreases in concentration resulting from decreased loading from nonpoint sources were offset by decreased dilution of loading from point sources.

\section{Changes in Nutrient Sources and Landscape Characteristics from 1993 to 2003}

The largest sources of phosphorus loading on the land surface in the Missouri River Basin between 1993 and 2003 varied more by region than did sources of nitrogen loading. Generally, phosphorus loads from fertilizer and manure were comparable in the upper basin; in the middle and lower basin, phosphorus loads from manure generally were slightly larger than phosphorus loads from fertilizer. In general, nutrients in fertilizer are more mobile than organically complexed nutrients in manure. As a result, changes in fertilizer loads may have a greater effect on in-stream phosphorus concentrations even in areas where manure loads are greater. This may not hold true in areas where manure loads are orders of magnitude greater than fertilizer loads, but that was not often the case in the Missouri River Basin. From 1993 to 2003, fertilizer loads of phosphorus generally increased at more than one-half of the sites in the basin; manure loads generally increased at only about one-quarter of the sites.

One notable relation was identified through the weighted least-squares regression analysis relating TP trends to changes in nutrient sources and landscape characteristics (fig. 13). The magnitude of the FA trend in TP concentrations was related to the change in fertilizer use in the full upstream drainage area $\left(R^{2}=0.45\right)$. When this comparison was limited to the change in fertilizer use in the nearest 10-percent drainage area, the relation was even stronger $\left(R^{2}=0.75\right)$. These results indicate that at sites throughout the Missouri River Basin, larger increases in TP concentrations occurred as fertilizer use in the upstream drainage area increased from 1993 to 2003. In addition, increasing fertilizer use in areas closer to the monitoring sites had a greater effect on TP concentrations than did fertilizer use in the full upstream drainage area. These relations were not seen with the NFA trends in TP concentrations, indi- 
(A) Flow-adjusted trends

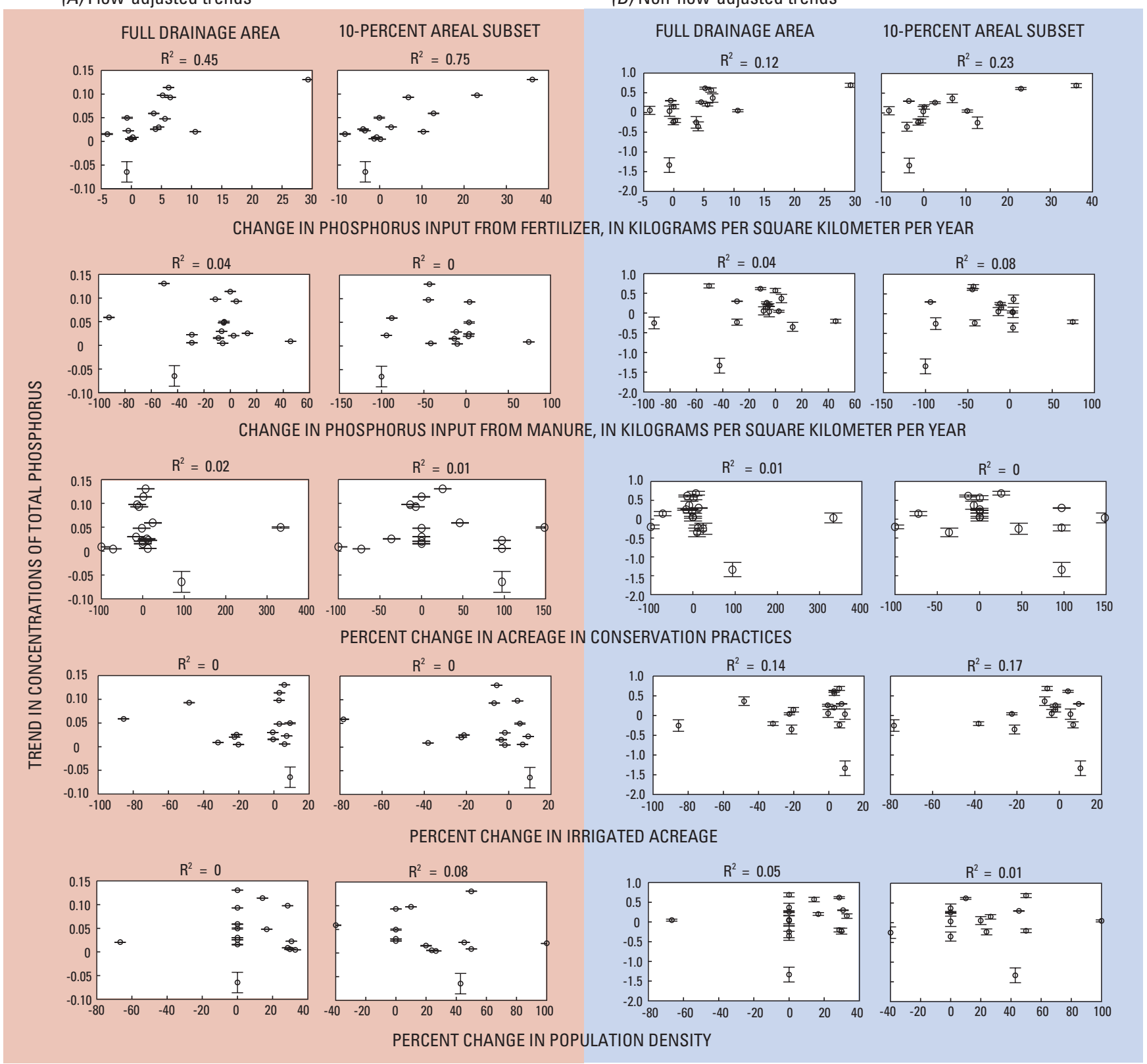

ㅇ. Error bars showing variance of the trend estimate
(B) Non-flow-adjusted trends 
cating that decreasing streamflow and associated decreasing surface runoff in the basin during the study period may have offset the effects of increasing fertilizer use.

Two weak relations were identified through the weighted least-squares regression analysis relating OP trends to changes in nutrient sources and landscape characteristics (fig. 14). The magnitude of the NFA trend in OP concentrations was related to the change in phosphorus loading from manure in the nearest 10 -percent drainage area $\left(\mathrm{R}^{2}=0.30\right)$ and to the change in the acreage in conservation practices in the nearest 10 -percent drainage area $\left(\mathrm{R}^{2}=0.33\right)$ during the study period. OP trends were not as strongly related to changes in phosphorus loading from manure or the acreage in conservation practices in the full drainage area, indicating that these changes had the greatest effect on OP concentrations in areas closer to the monitoring site. The relation with loading from manure indicates that, at sites throughout the Missouri River Basin, larger increases in OP concentrations were associated somewhat with increased loading from manure from 1993 to 2003. The relation with changes in the acreage in conservation practices seemed to indicate that as the acreage in conservation practices decreased from 1993 to 2003, smaller decreases in OP concentrations occurred. However, assessment of the effects of acreage in conservation practices was limited by the absence of conservation tillage in the data set. The relation between changes in the acreage in conservation practices and trends in OP concentrations may have differed had conservation tillage been included in the analysis.

\section{Trends from 1985 to 2003}

\section{Total Phosphorus}

Significant FA trends in TP concentrations were detected at six of seven sites (fig. 15, Appendix 7). There was a downward FA trend at one site (site 25) and an upward FA trend at four sites (site 39, site 42, site 44, and site 58) at some point during the period from 1985 to 2003 . As with the LODAEST program, more upward trends were detected in TP concentrations than in TN or NOX concentrations using the QWTREND program. One site (site 24) had increases and (or) decreases during multiple trend periods.

At site 24, there was an upward FA trend in TP concentrations from 1985 to 1991 , followed by a downward trend from 1992 to 1996 and a second upward trend from 1997 to 2003. The upward trend from 1997 to 2003 probably affected the LOADEST results, indicating that a consistent monotonic FA trend may not have occurred over the entire period from 1993 to 2003. At site 25, there was a downward FA trend in TP concentrations from 1985 to 1991 . The lack of a trend after 1991 was consistent with the nonsignificant FA trend found using the LOADEST program. At site 39, there was an upward FA trend in TP concentrations from 1993 to 2003; no trend model could be fit to the TP data at site 39 using the LOADEST program. At site 51, there were no FA trends detected at any time between 1985 and 2003; however, an upward FA trend from 1993 to 2003 was detected using the LOADEST program. The reason for this inconsistency is unknown, but it is possible that the QWTREND program removed more of the variability in streamflow and concentration than did the LOADEST program, leading to different FA trend results. There were upward FA trends in TP concentrations at three sites (sites 42, 44, and 58) from 1985 to 2003. Sites 44 and 58 are located on the main stem of the Missouri River. The trend results at these sites were consistent with the upward trend detected by the LOADEST program from 1993 to 2003. The significant trend from 1985 to 2003 detected by the QWTREND program may indicate that the upward monotonic trend detected by the LOADEST program from 1993 to 2003 was part of a longer monotonic increase.

\section{Orthophosphorus}

A significant FA trend in OP concentrations was detected at only one of four sites at some point during the period from 1985 to 2003 (fig. 16, Appendix 7). At site 58, there was a small upward FA trend from 1985 to 1991. The lack of any trend after 1991 was consistent with the nonsignificant FA trend found using the LOADEST program. At sites 39 and 42, no trends were detected during the period from 1985 to 2003; no trend model could be fit to the OP data at these sites using the LOADEST program. At site 44, no trend was detected during the period from 1985 to 2003. In contrast, a downward FA trend from 1993 to 2003 was detected using the LOADEST program.

\section{Suspended Sediment}

\section{Trends from 1993 to 2003}

There were nonsignificant FA trends in SS concentrations at 10 of 18 sites and downward FA trends at 6 of 18 sites (fig. 17A, Appendix 4). These results indicate that at some sites, pollution-control strategies or other human activities were contributing to a measurable decrease in SS concentrations, but at the majority of sites, there were no measurable effects. There were more downward FA trends and fewer upward FA trends in SS concentrations than in TP concentrations. Although TP can be transported by sorption to particulate material, the different trend patterns of the two constituents indicates that changes in SS concentrations are not contributing to a concomitant change in TP concentrations in the Missouri River Basin. Factors affecting TP concentrations were to some degree independent of those affecting SS concentrations.

From 1993 to 2003, there were downward NFA trends in SS concentrations at 12 of 18 sites (fig. 17B, Appendix 5). This indicates that at more than one-half of the sites, overall SS concentrations (affected by any and all factors in the 
(A) Flow-adjusted trends

(B) Non-flow-adjusted trends

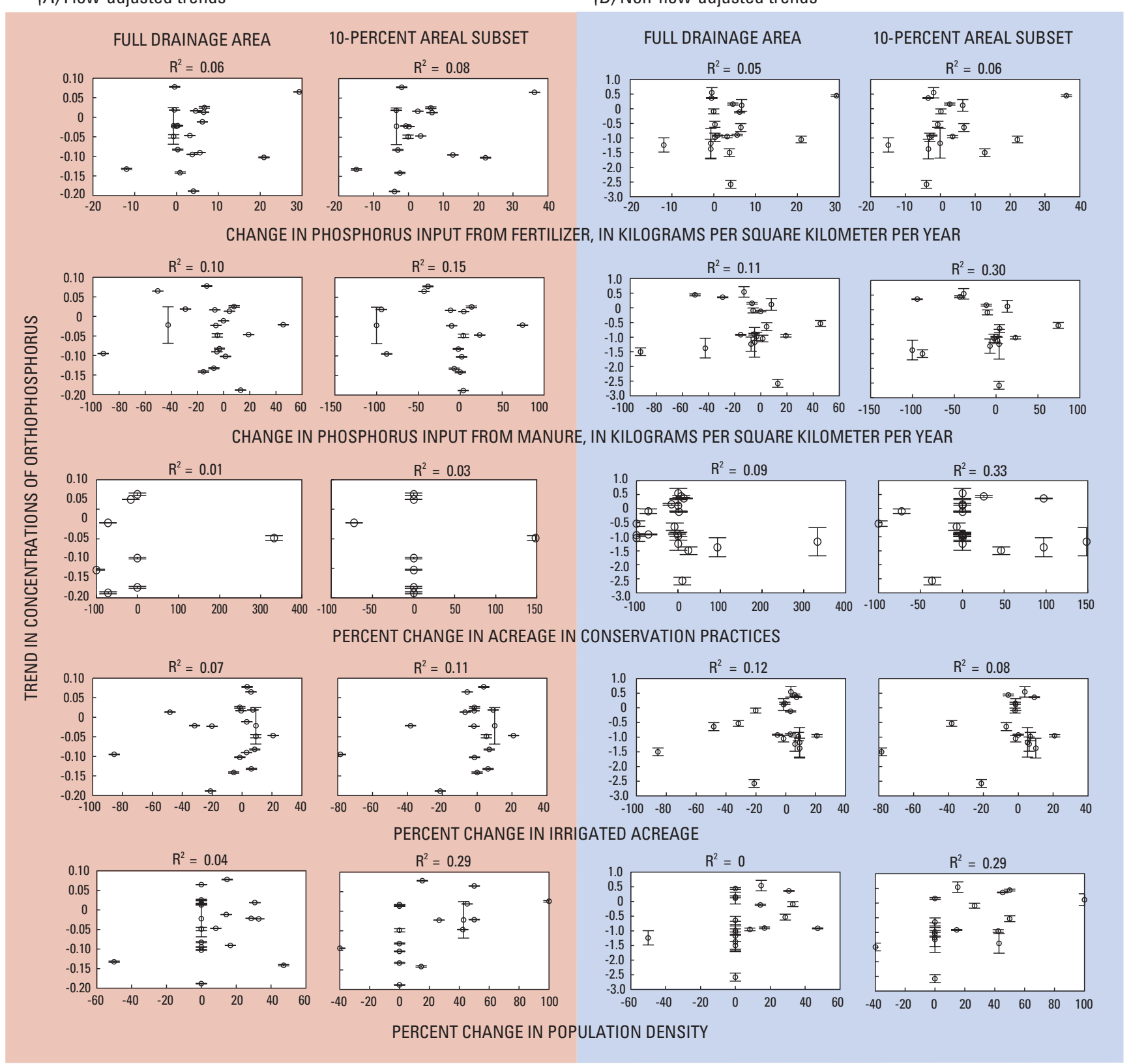

\section{EXPLANATION}

오 Error bars showing variance of the trend estimate

$\mathrm{R}^{2}$ Coefficient of determination

Figure 14. (A) Flow-adjusted and $(B)$ non-flow-adjusted trends in concentrations of orthophosphorus compared to changes in nutrient sources and landscape characteristics from 1993 to 2003. 


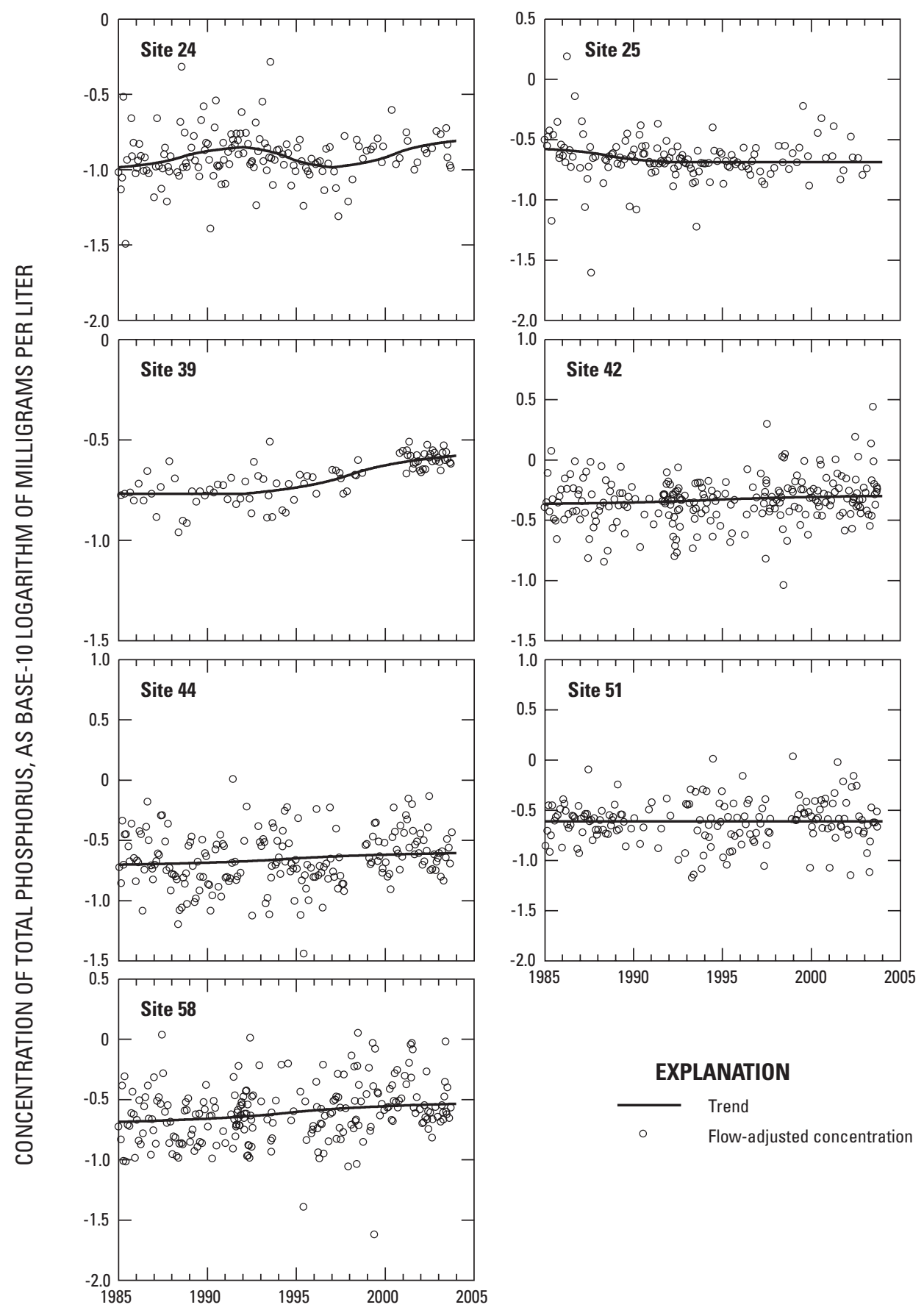

Figure 15. Flow-adjusted trends in concentrations of total phosphorus from 1985 to 2003. Location of sites shown in figure 1. 


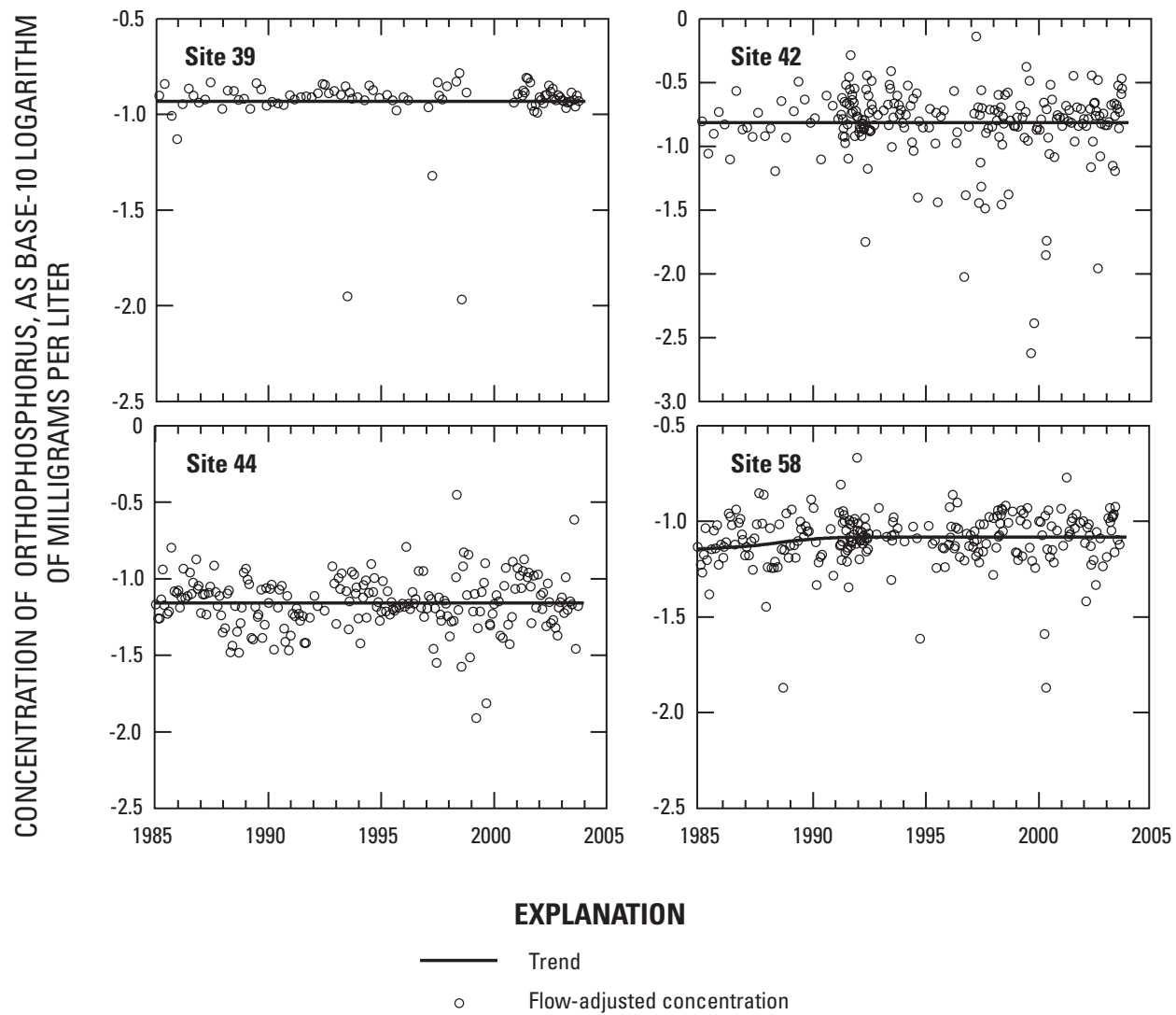

Figure 16. Flow-adjusted trends in concentrations of orthophosphorus from 1985 to 2003. Location of sites shown in figure 1.

upstream basin) decreased significantly during this period. The greater number of downward NFA trends as compared to downward FA trends indicates that naturally decreasing streamflow over the study period may have been as or more influential in decreasing the concentrations of SS than were pollution-control strategies or other human activities. There was an upward NFA trend in SS concentrations at only one site.

The combination of FA, NFA, and streamflow trends at a site most frequently observed (6 of 18 sites) was a nonsignificant FA trend, a downward NFA trend, and downward streamflow trend. At these sites, the nonsignificant FA trends indicated that pollution-control strategies and other human activities were not contributing to a measurable decrease in SS concentrations. The downward NFA trends were resulting from something other than pollution-control strategies or other human activities; most likely, the decreasing concentrations were a result of decreasing streamflow and associated surface runoff. If streamflow had not decreased during this period, it is unlikely that concentrations of SS would have decreased. At four other sites, there were downward FA, NFA, and streamflow trends. At these sites, the downward FA trends indicated that pollution-control strategies and other human activities were contributing to a measurable decrease in SS concentrations. At some sites, the downward FA trends were greater in magnitude than the downward NFA trends, indicating that although increased concentrations from decreased dilution may have been offsetting decreases resulting from pollution-control strategies and other human activities, these increases were not great enough to prevent downward NFA trends. At other sites, the downward FA trends were smaller in magnitude than the downward NFA trends, indicating that the decrease in concentrations due to decreased streamflow and associated surface runoff may have been greater than the decrease in concentration due to pollution-control strategies and other human activities. 
(A) Flow-adjusted trends

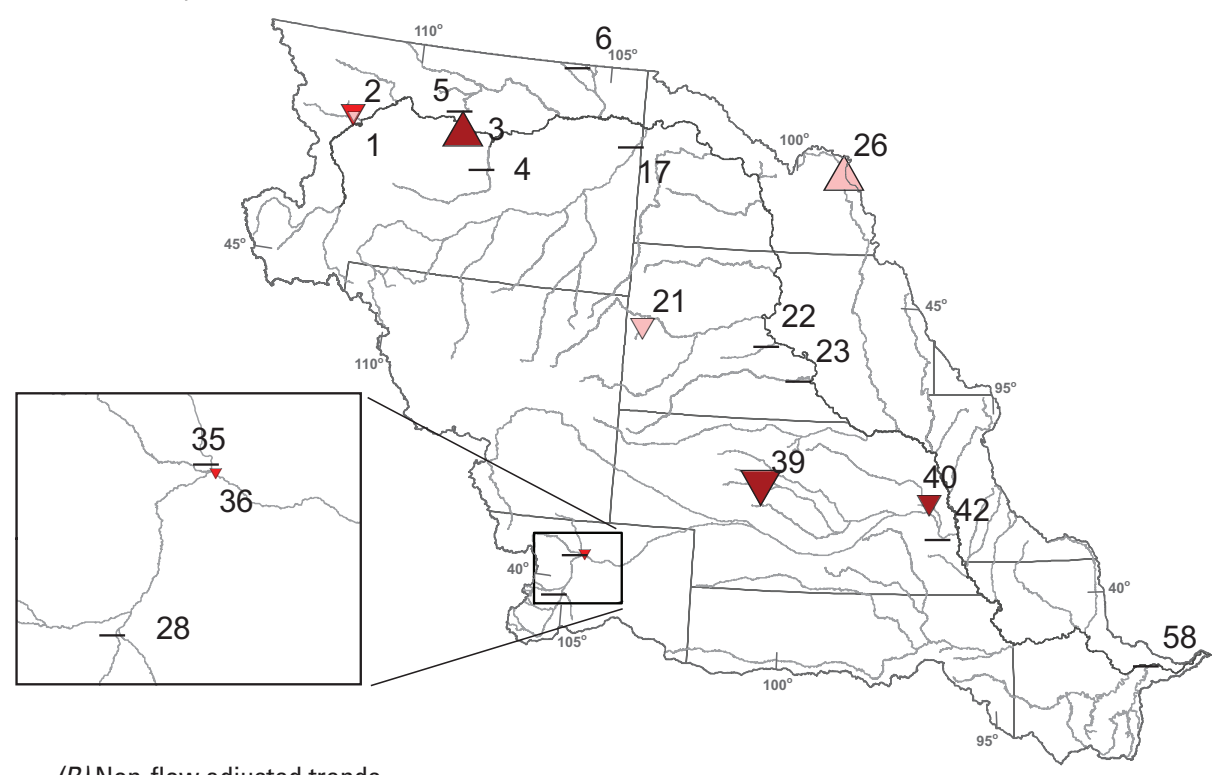

(B) Non-flow adjusted trends

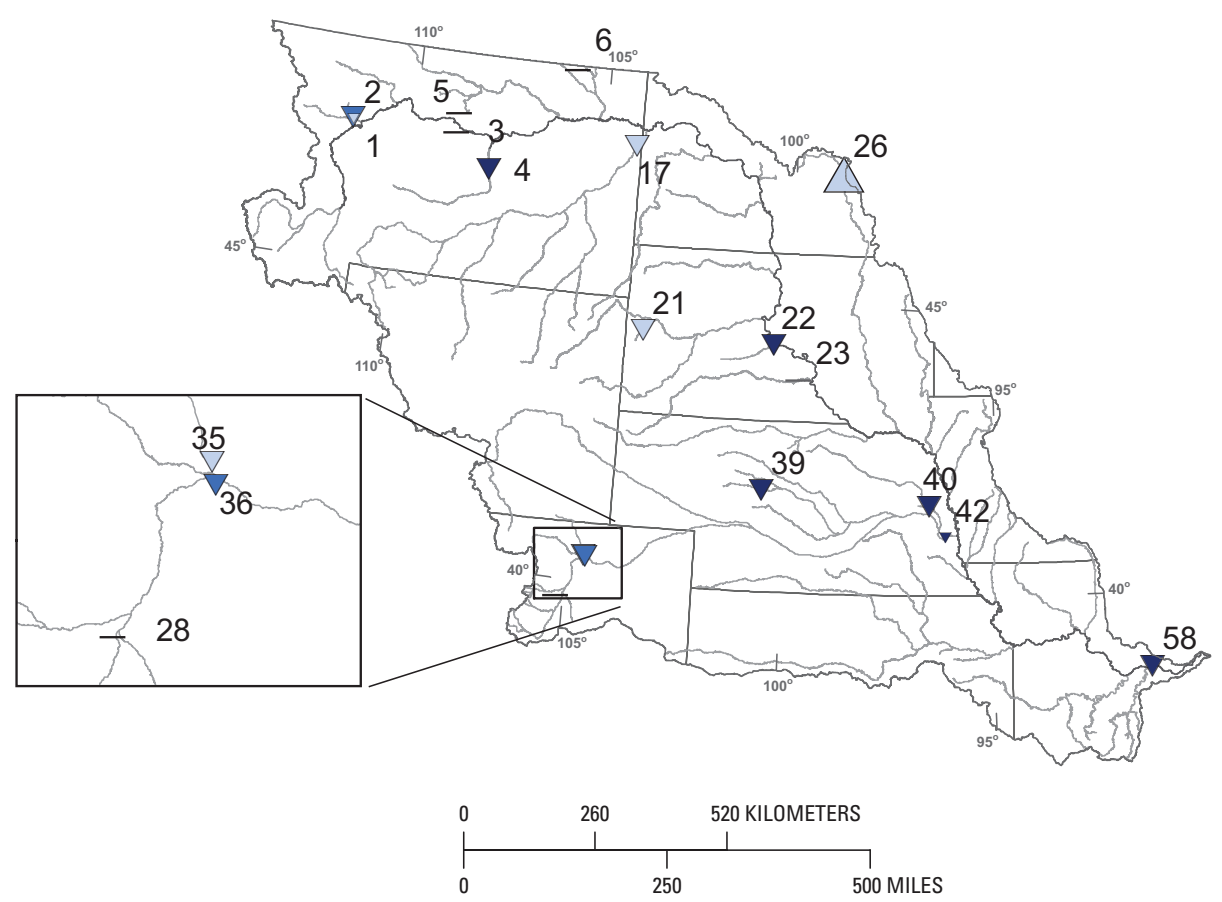

EXPLANATION

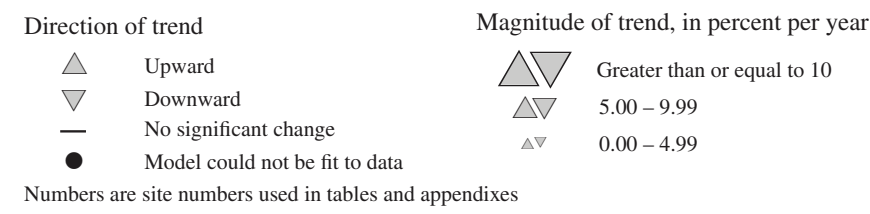

Reference concentration, in milligrams per liter Suspended sediment

Flow adjusted Non-flow adjusted

$\begin{aligned} & \text { Greater than } \\ & \text { or equal to } 200\end{aligned} \quad \begin{aligned} & \text { Greater than } \\ & \text { or equal to } 200\end{aligned}$

$100-199$

$100-199$

$0-99$

$0-99$

Figure 17. ( $A)$ Flow-adjusted and $(B)$ non-flow-adjusted trends in concentrations of suspended sediment from 1993 to 2003 at selected locations in the Missouri River Basin. 
Changes in Landscape Characteristics from 1993 to 2003

Sediment loading to streams in the Missouri River Basin is affected by surface runoff, which in turn is affected by many factors, including impervious surface area, precipitation rates, irrigation rates, and implementation of conservation practices. Many of these factors are not well quantified. There is limited information available about acreage in irrigation or conservation practices, but this information is not available in all areas of the basin and does not include all types of conservation practices that may affect sediment runoff. As a result, the data on irrigation and conservation practices must be used with caution.

No strong relations were identified through the weighted least-squares regression analysis of SS trends and changes in landscape characteristics. The strongest relation identified was between the FA trend in SS concentrations and the change in irrigated acreage in the nearest 10-percent drainage area $\left(\mathrm{R}^{2}=0.26\right)$ (fig. 18A), but this regression was affected by an outlier that may have inflated the $\mathrm{R}^{2}$ value.

\section{Trends from 1985 to 2003}

There were significant FA trends in SS concentrations at three of seven sites at some point during the period from 1985 to 2003 (fig. 19, Appendix 7). There was a downward trend at one site (site 4), and two sites (sites 3 and 58) had increases and (or) decreases during multiple trend periods.

At site 3, a downward FA trend in SS concentrations occurred from 1985 to 1996, followed by an upward trend from 1997 to 2003. The upward trend from 1997 to 2003 probably affected the results from the LOADEST program, indicating that a consistent monotonic FA trend may not have occurred over the entire period from 1993 to 2003. At site 4, a downward FA trend in SS concentrations occurred from 1985 to 1991 . The lack of any trend after 1991 is consistent with the nonsignificant trend results from 1993 to 2003 found using the LOADEST program. At site 58, an upward FA trend in SS concentrations occurred from 1985 to 1991, followed by a downward trend from 1992 to 2003. These results are inconsistent with the nonsignificant FA trend from 1993 to 2003 found using the LOADEST program. The reason for this inconsistency is unknown, but it is possible that the QWTREND program removed more of the variability in streamflow and concentration than did the LOADEST program, leading to different FA trend results. At sites 17, 22, 23, and 42, no FA trends were detected in SS concentrations from 1985 to 2003. These results are consistent with the nonsignificant trends from 1993 to 2003 found using the LOADEST program.

\section{Spatial Patterns in Sediment Yield}

For the 32 sites used in the analysis of spatial patterns in MDSYs, a summary of the mean daily sediment load estimates and the contributing drainage areas used to calculate MDSYs is given in Appendix 8; MDSYs are shown in figure 20. At sites $16,17,49,54$, and 56 , the standard deviation of the load was greater than the load; this could be a limitation of using regression techniques (such as LOADEST) in characterizing highly episodic (sites 16 and 17 are affected greatly by snowmelt) or small (sites 54 and 56 have comparatively small drainages) watersheds (Schwarz and others, 2001). These sites were omitted from further analysis.

Eleven of the study sites included large reservoirs (those having $49.3 \times 10^{6} \mathrm{~m}^{3}$ or more of storage) within their drainage area. Reservoirs act as sediment traps (Williams and Wolman, 1984) and can systematically dampen the effects of upstream watershed factors on the sediment load measured downstream from the reservoir. For sites downstream from reservoirs, the comparisons of MDSY with spatial data derived from the entire watershed need to be made with caution. Three of the sites in the Kansas River Basin (sites 45, 48, and 50) were omitted from the spatial-sediment analysis (with the exception of the comparison to percentage unregulated area) because 83, 99 , and 89 percent, respectively, of their drainage areas were affected by reservoirs.

In general, the WLS regression showed weak relations between the MDSYs and the eight landscape characteristics (table 3). Because sediment erosion and transport are a function of many interactive effects, this was not unexpected. To reduce variability among sites, the sites subsequently were grouped according to (1) percentage of cultivated area (using 20 percent as a grouping threshold), (2) dominant physiographic division (Interior Plains and the Rocky Mountains), (3) stream density (using a density index of $0.75 \mathrm{~km} / \mathrm{km}^{2}$ as a grouping threshold), and (4) contributing drainage area (using $15,000 \mathrm{~km}^{2}$ as a grouping threshold). Graphical comparisons of the grouped MDSYs to the eight landscape characteristics then were made to identify which grouping variable was most effective at reducing variability. Of the four potential variables, stream density was most effective, cultivated area was slightly less effective, and dominant physiographic division and contributing drainage area were ineffective at reducing variability. Stream density often is inversely related to overbank-sediment storage (which would reduce sediment yields) and positively related to basin slope (which would increase sediment yields) (Schumm, 1977). Results from the weighted least-squares regressions showed slightly stronger relations between the MDSYs and the eight landscape characteristics when the sites were grouped by stream density. However, the sample size of the grouped MDSYs was smaller, and interpretations that were based on these relations are considered to be qualitative.

When the sites were not grouped and all were included together, the soil-erodibility factor $(\mathrm{K})$ appeared to have a positive relation to MDSY (table 3). However, after being grouped by high and low stream densities, the relation of MDSY to K was much less pronounced, indicating that the $\mathrm{K}$ factor may have little or no effect on MDSY relative to the stream density (fig. 21A). In general, the relation of MDSY to the soil-runoff factor $(\mathrm{R})$ was weak whether stream-density 
(A) Flow-adjusted trends

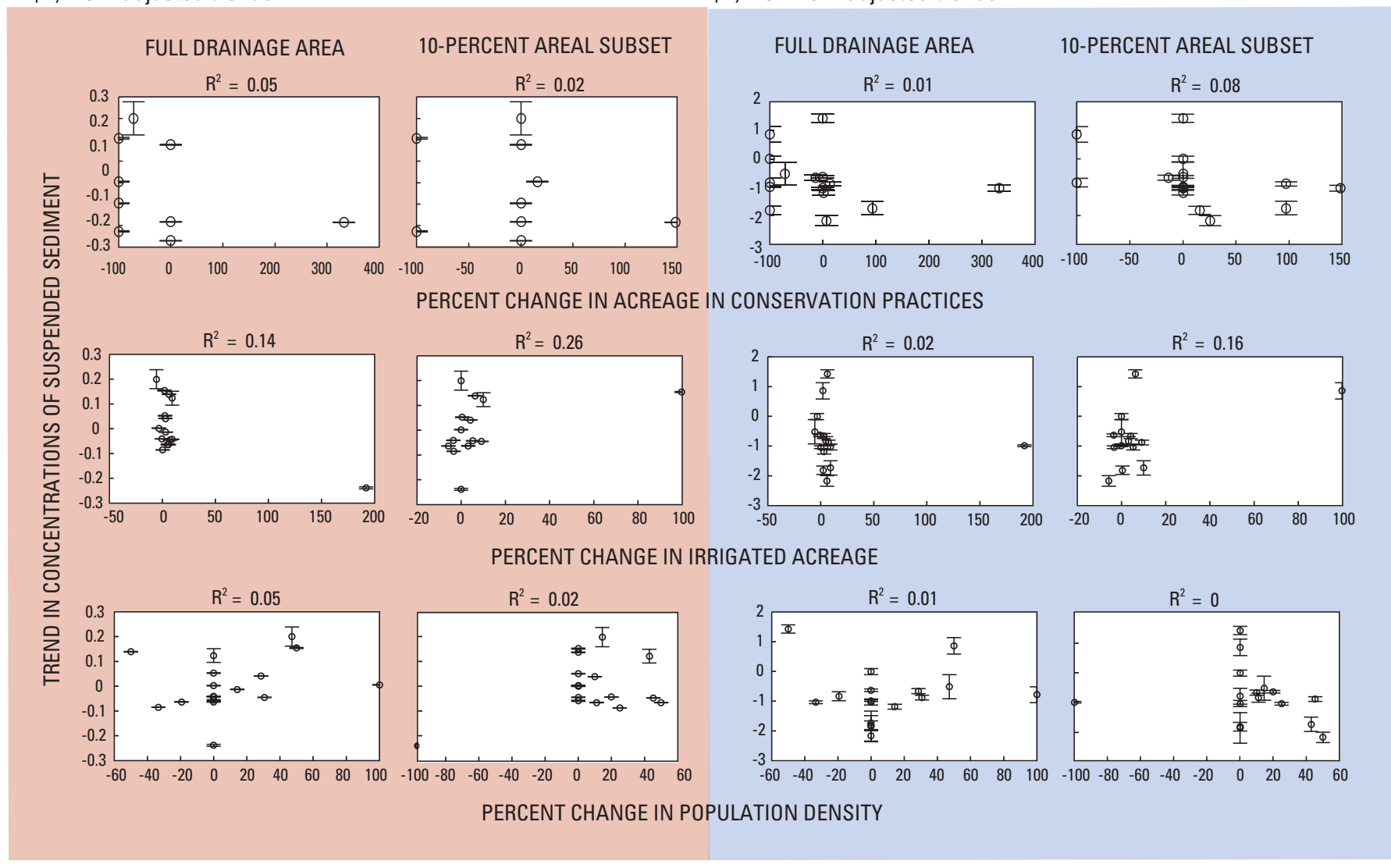

오 Error bars showing variance of the trend estimate

Figure 18. ( $A)$ Flow-adjusted and $(B)$ non-flow-adjusted trends in concentrations of suspended sediment compared to changes in landscape characteristics from 1993 to 2003. 

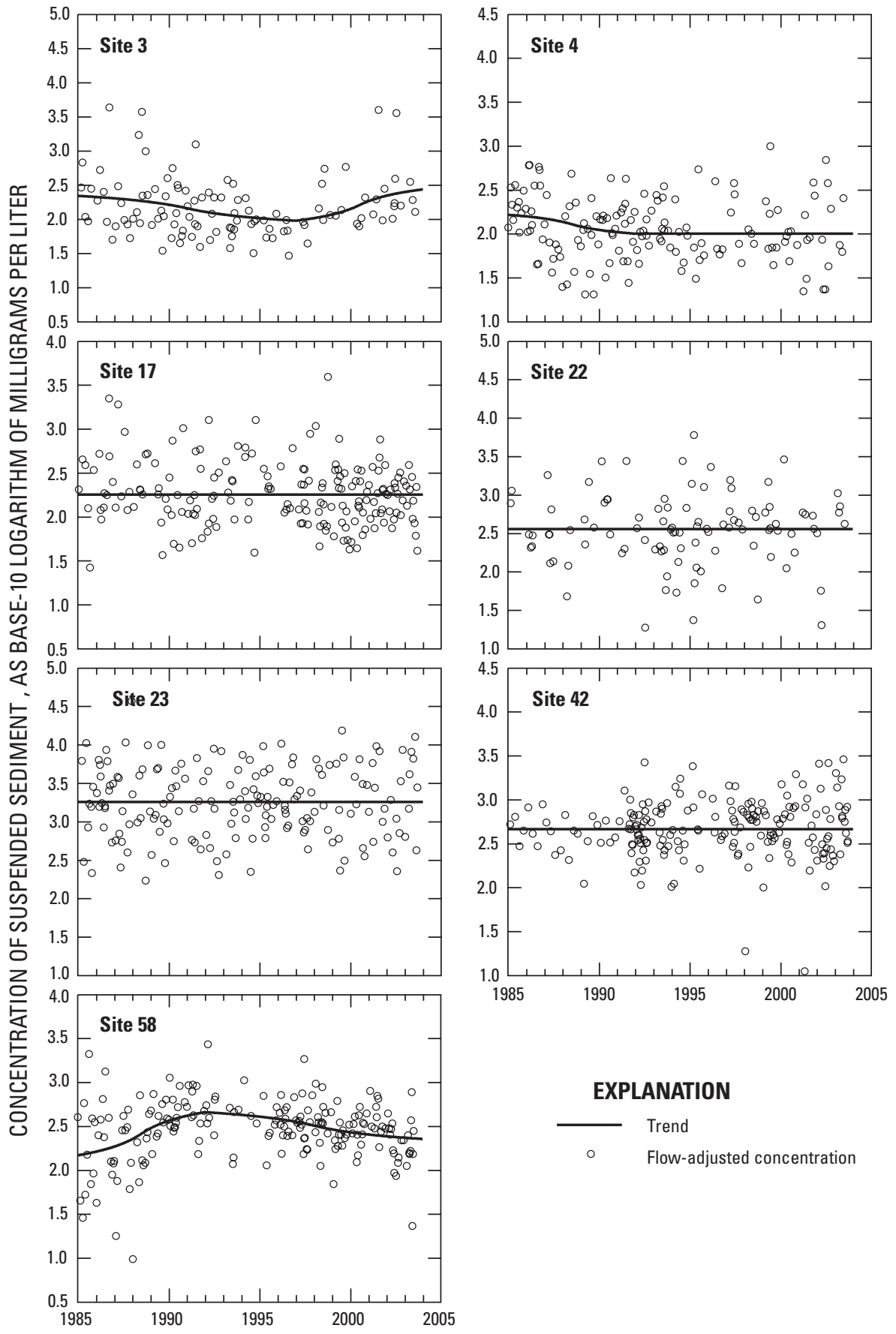

EXPLANATION

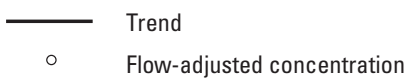

Figure 19. Flow-adjusted trends in concentrations of suspended sediment from 1985 to 2003. Location of sites shown in figure 1. 


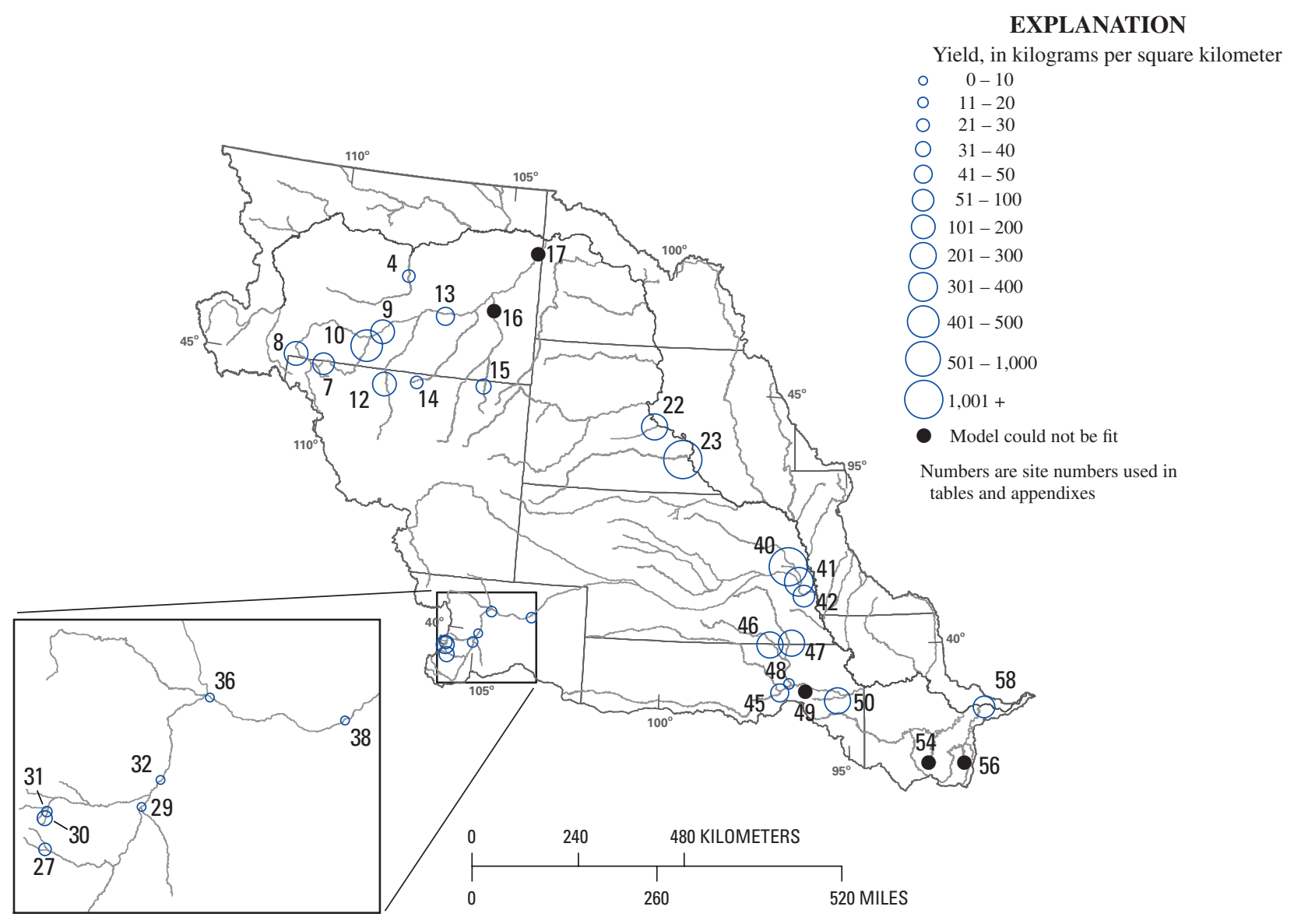

Figure 20. Yields of suspended sediment at selected locations in the Missouri River Basin.

Table 3. Summary of weighted least-squares regressions of mean daily sediment yields and landscape characteristics. [n, number of samples; $\mathrm{R}^{2}$, coefficient of determination; $\mathrm{km}$, kilometer; $\mathrm{km}^{2}$, square kilometer; $\mathrm{ln}$, natural logarithm]

\begin{tabular}{|c|c|c|c|c|c|c|}
\hline \multirow[t]{2}{*}{ Landscape characteristic } & \multicolumn{2}{|c|}{$\begin{array}{l}\text { All sites } \\
(\mathrm{n}=24)\end{array}$} & \multicolumn{2}{|c|}{$\begin{array}{l}\text { Low stream- } \\
\text { density sites } \\
\quad(n=15)\end{array}$} & \multicolumn{2}{|c|}{$\begin{array}{l}\text { High stream- } \\
\text { density sites } \\
(\mathrm{n}=9)\end{array}$} \\
\hline & Slope & $\mathbf{R}^{2}$ & Slope & $\mathbf{R}^{2}$ & Slope & $\mathbf{R}^{2}$ \\
\hline Soil-erodibility factor, $\mathrm{K}$ & 3.2 & 0.22 & -3.2 & 0.23 & 23 & 0.50 \\
\hline Soil-runoff factor, $\mathrm{R}$ & -0.048 & 0.12 & -0.048 & 0.12 & 0.025 & 0.17 \\
\hline Percentage cultivated area & -0.084 & 0.11 & -0.093 & 0.12 & 0.023 & 0.55 \\
\hline $\begin{array}{l}\text { Percentage in the Interior Plains physio- } \\
\text { graphic division }\end{array}$ & -0.025 & 0.29 & -0.025 & 0.30 & 0.019 & 0.59 \\
\hline $\begin{array}{l}\text { Percentage in Plains hydrologic landscape } \\
\text { regions }\end{array}$ & -0.081 & 0.21 & -0.087 & 0.23 & 0.018 & 0.52 \\
\hline Stream density, in $\mathrm{km} / \mathrm{km}^{2}$ & -1.7 & 0.29 & -1.7 & 0.29 & 7.4 & 0.52 \\
\hline $\ln$ (contributing drainage area), in $\mathrm{km}^{2}$ & -0.15 & 0.48 & -0.15 & 0.48 & -0.70 & 0.94 \\
\hline${ }^{2}$ Percentage unregulated area & 0.024 & 0.31 & 0.033 & 0.37 & 0.033 & 0.69 \\
\hline
\end{tabular}

${ }^{1}$ Sites were grouped by stream density by using a threshold value of $0.75 \mathrm{~km} / \mathrm{km}^{2}$.

${ }^{2}$ Three additional high-stream density sites (sites 45,48 , and 50) were included in the unregulated-area comparison. 

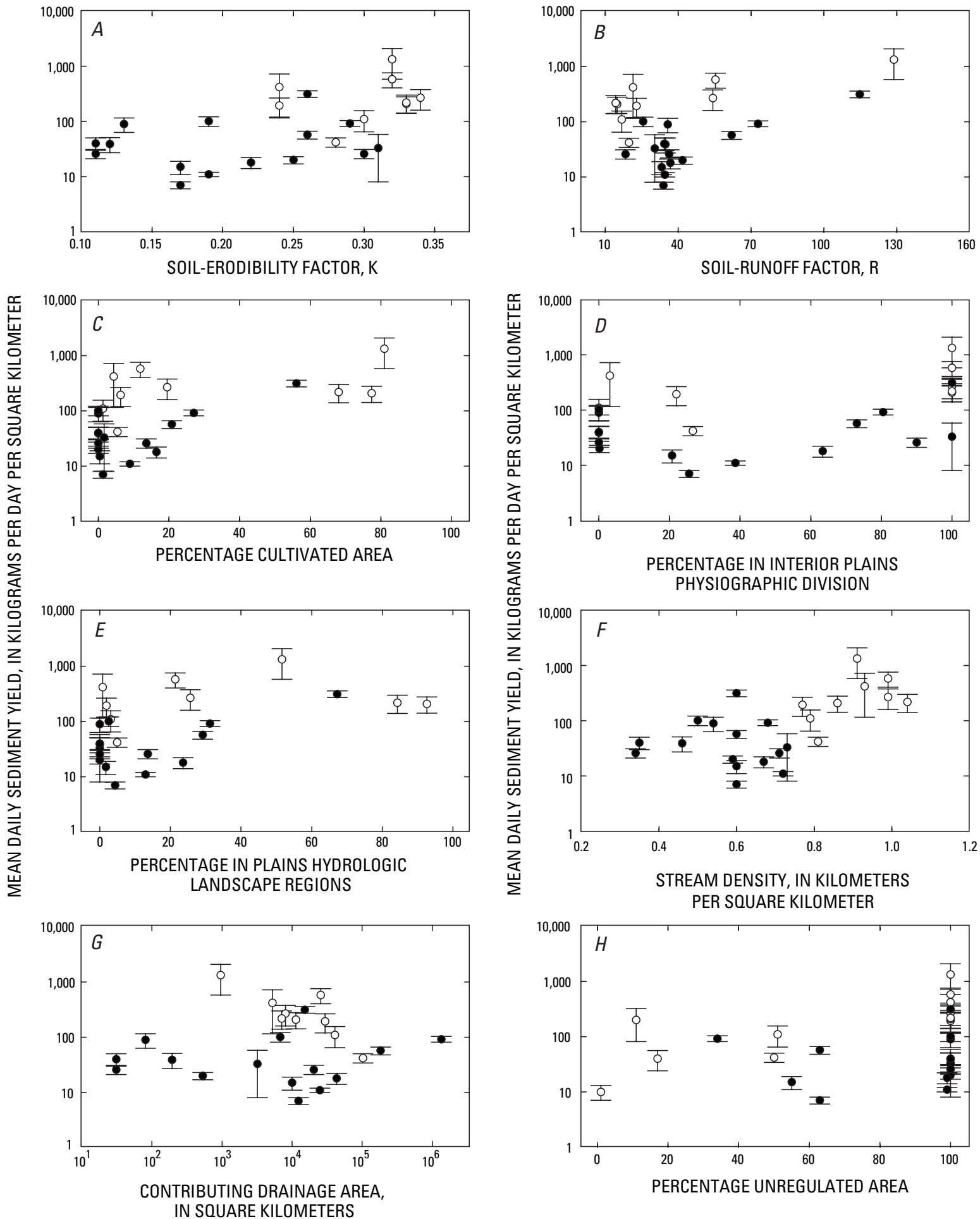

EXPLANATION

O Sites with stream densities greater than 0.75 kilometers per square kilometer

- Sites with stream densities less than 0.75 kilometers per square kilometer

오 Error bars showing one standard deviation above and below the yield estimate

Figure 21. Suspended-sediment yields compared to changes in landscape characteristics. 
grouping was used or not. However, plots of MDSY against $\mathrm{R}$ indicated a positive relation with MDSY that was shifted upward when stream densities were high (fig. 21B). As the percentage of cultivated area increased, MDSY increased, although this effect was reduced when the sites were grouped by stream density (fig. 21C). In the low stream-density group, the weak relations in part were the result of MDSY variability at sites with little or no cultivated area. The percentage of the watershed in the Interior Plains physiographic division did not show a clear relation to MDSY, and grouping the sites by stream density did not strengthen the relation (fig. 21D). Similarly, the percentage of the watershed in hydrologic landscape regions classified as Plains did not relate well with MDSY (fig. 21E). Both of these landscape classification systems incorporated several different parameters into one category, including some parameters that may not be directly related to sediment yields; this may explain their weak relations to MDSY. Contributing drainage area also was weakly related to MDSY when the sites were not grouped, but grouping by stream density provided insight into this relation (fig. 21G). Whereas drainage area was weakly related to MDSY at low stream-density sites, drainage area was strongly and negatively related to MDSY at high-stream density sites (table 3). This may indicate that the sediment-delivery ratio technique for estimating sediment yields may be more applicable in watersheds with stream densities greater than $0.75 \mathrm{~km} / \mathrm{km}^{2}$ and that the effects of increased overbank storage in low stream-density watersheds may add uncertainty to the technique. Because of the sediment-trapping effect of reservoirs, it was expected that the percentage of unregulated area in each watershed would directly relate to MDSY. The three sites with less than 20 percent unregulated area were omitted from comparisons with the other seven landscape characteristics but were included in the comparison with unregulated area. Unregulated area was weakly related to MDSY when sites were not grouped; the relation was stronger when the sites were grouped by stream density, especially at the high stream-density sites (fig. $21 \mathrm{H}$ ). However, it is possible that the correlation coefficients were elevated artificially by the relatively few sites containing large reservoirs.

The univariate weighted least-squares regression approach was used to compare MDSYs with landscape characteristics in this study to incorporate the error of the yield estimates. However, sediment yields can be affected by numerous interacting watershed characteristics. On a field scale, sediment yield can be affected by precipitation, soil erodibility, vegetative cover, topography, and land practices (Renard and others, 1996). On a watershed scale, many of these same factors may still affect sediment yield in streams (Leopold and others, 1964), but added complexities at this scale are the additional fluvial sediment introduced through streambank erosion (Trimble, 1997) and the effect of sediment-transport zones along the longitudinal stream profile (Schumm, 1977). The concept of sediment-transport zones is the basis behind the empirical sediment delivery ratio model (Soil Conservation Service, 1983), in which sediment yield generally decreases as drainage area increases (Trimble and Crosson, 2000). Because of these interacting effects, a multivariate approach that accounts for the error in the original load estimates might prove more useful in future studies describing spatial patterns of sediment yields.

The differential relation between MDSY and drainage area at sites with high stream densities as compared to sites with low stream densities indicates that the role of overbank storage on sediment delivery to streams may be dependent on stream density. At a high stream-density site where overbank storage has little effect on sediment loading to the stream, a newly implemented BMP designed to minimize surface runoff may contribute to an immediate reduction in in-stream SS concentrations. In contrast, at a low stream-density site where overbank storage occurs, a newly implemented BMP may not have a clear effect on in-stream SS concentrations because the sediment loading prior to BMP implementation would have already been attenuated by overbank storage. As a result, natural spatial differences in stream density and overbank storage may lead to differences in how SS concentrations change temporally at sites in the Missouri River Basin. It is possible that these differences contributed to the spatial variability in FA trends in SS throughout the basin where pollution-control strategies appeared to have measurable effects on in-stream concentrations at some sites but not others from 1993 to 2003.

\section{Implications for Management of Water Resources in the Missouri River Basin}

Longer term non-monotonic changes in streamflow indicate that the decreasing streamflows observed from 1993 to 2003 in the Missouri River Basin likely will not continue indefinitely. In some parts of the basin, nutrient and suspended-sediment concentrations may have been higher without the decrease in streamflow and the associated decrease in surface runoff that occurred during the study period. Without additional steps to minimize surface runoff or nutrient loading on the land, it is possible that concentrations will increase when streamflow and surface runoff begin to increase once again. This may be of particular concern for phosphorus given the strong relation between increasing phosphorus concentrations and increasing fertilizer use in the 10-percent of the drainage area closest to the monitoring sites. Although decreasing streamflow and associated decreasing surface runoff may have offset the effects of increasing fertilizer use during the study period, this pattern is unlikely to continue when surface runoff and streamflow begin to increase again.

In addition, results from three case studies indicate that a substantial portion of the total flow and nitrate load in streams may consist of ground-water inflow in some parts of the basin. In these areas, nutrient loading to streams may be best addressed by management practices focused not only on reducing surface runoff but also on maintaining and (or) improving ground-water quality. Because of the time required 
for ground water to travel to streams, there may be a lag time between the implementation of some pollution-control strategies and improvement in stream quality. This lag time, which may range from days to decades, should be considered in the development of future stream management plans.

\section{Summary and Conclusions}

In 1987, the U.S. Geological Survey began a study of more than 50 major river basins and aquifers across the Nation as part of the National Water-Quality Assessment Program. One of the major goals of the NAWQA Program is to determine how water-quality conditions change over time. Within the Missouri River Basin, the NAWQA Program has collected long-term water-quality data in the Yellowstone River Basin in Wyoming, Montana, and North Dakota; the South Platte River Basin in Colorado, Wyoming, and Nebraska; the Platte River Basin in Nebraska; and the Ozark Plateaus in Kansas and Missouri. Outside of the NAWQA Program, the USGS has collected additional long-term data throughout the Missouri River Basin in cooperation with other Federal, State, and local agencies. For this study, these data were compiled to provide insight into how water-quality conditions have changed over time in the Missouri River and its tributaries and how natural features and human activities have contributed to those changes.

This report describes the methods and results of a study of nutrient and suspended-sediment trends in the Missouri River Basin from 1993 to 2003. The major objectives of the study were to: (1) determine trends in nutrients and suspended-sediment concentrations at selected stream sites in the Missouri River Basin and (2) describe the factors affecting those trends. Trends were calculated for total nitrogen, nitrite plus nitrate, ammonia, total phosphorus, orthophosphorus, and suspended sediment for the period from 1993 to 2003. Flow-adjusted trends in concentration (the trends that would have occurred in the absence of natural changes in streamflow) and non-flow-adjusted trends in concentration (the overall trends resulting from both natural and human factors) were determined, and relations between these trends and changes in streamflow, nutrient sources, ground-water inputs, and implementation of management practices were examined. Secondary objectives of the study were to (1) place the streamflow and flow-adjusted trends from 1993 to 2003 in a longer context by comparing them to longer term, non-monotonic trends from 1985 to 2003 at a subset of the sites, (2) examine the effect of ground water on trends in nitrite plus nitrate loading in surface water, (3) compare spatial differences in sediment yields, and (4) examine the scale-dependency of the relation between trends and the factors affecting those trends.

From 1993 to 2003, widespread downward trends in streamflow indicated that drought conditions from about 2000 to 2003 led to decreasing streamflow throughout the Missouri River Basin. Flow-adjusted trends in nitrite plus nitrate and ammonia concentrations were split nearly equally between nonsignificant and downward; at about one-half of the sites, management practices likely were contributing to measurable decreases in concentrations of nitrite plus nitrate and ammonia. Management practices had less of an effect on concentrations of total nitrogen; downward flow-adjusted trends in total nitrogen concentrations occurred at only two sites. The pattern of non-flow-adjusted trends in nitrite plus nitrate concentrations was similar to the pattern of flow-adjusted trends; non-flow-adjusted trends were split nearly equally between nonsignificant and downward. A substantial source of nitrite plus nitrate to these streams likely was ground water; because of the time required for ground water to travel to streams, there may have been a lag time between the implementation of some pollution-control strategies and improvement in stream quality, contributing to the nonsignificant trends in nitrite plus nitrate concentrations. There were more downward non-flow-adjusted trends than flow-adjusted trends in both total nitrogen and ammonia concentrations, possibly a result of decreased surface runoff from nonpoint sources associated with the downward trends in streamflow. No strong relations between any of the nitrogen trends and changes in nutrient sources or landscape characteristics were identified.

Although there were very few upward trends in nitrogen from 1993 to 2003, there were upward flow-adjusted trends in total phosphorus concentrations at nearly one-half of the sites. At these sites, not only were best management practices or other pollution-control strategies not contributing to measurable decreases in total phosphorus concentrations, there was likely an increase in phosphorus loading on the land surface. There were fewer upward non-flow-adjusted than flow-adjusted trends in total phosphorus concentrations; at the majority of sites, overall total phosphorus concentrations did not change significantly during this period. The preponderance of upward flow-adjusted trends and nonsignificant non-flowadjusted trends indicates that in some areas of the Missouri River Basin, overall concentrations of total phosphorus would have been higher without the decrease in streamflow and the associated decrease in surface runoff during the study period. During the study period, phosphorus loads from fertilizer generally increased at more than one-half of the sites in the basin. Upward flow-adjusted trends were related to increasing fertilizer use in the upstream drainage area, particularly in the 10-percent of the drainage area closest to the monitoring site. This relation was not seen with the non-flow-adjusted trends in total phosphorus concentrations, indicating that decreasing streamflow and associated decreasing surface runoff in the basin during the study period may have offset the effects of increasing fertilizer use.

There were fewer upward trends in suspended-sediment concentrations than in total phosphorus concentrations. Although phosphorus can be transported by sorption to particulate material, the different trend patterns of the two constituents indicate that changes in suspended-sediment concentrations were not contributing to a concomitant change in total phosphorus concentrations in the Missouri River 
Basin. At some sites, pollution-control strategies or other human activities were contributing to a measurable decrease in suspended-sediment concentrations, but at the majority of sites, there were no measurable effects from pollution-control strategies. Spatial differences in stream density and overbank storage may have contributed to the spatial variability in flow-adjusted trends in suspended-sediment concentrations throughout the basin. Sediment loading was probably less affected by overbank storage at sites with higher stream densities, and consequently, pollution-control strategies may have contributed to measurable decreases in suspended-sediment concentrations at these sites. In contrast, at low stream-density sites where overbank storage was occurring, pollution-control strategies may not have contributed to measurable changes in suspended-sediment concentrations because the sediment loading prior to BMP implementation would have already been attenuated by overbank storage. There were more downward non-flow-adjusted trends than downward flow-adjusted trends in suspended-sediment concentrations, indicating that naturally decreasing streamflow over the study period was as or more influential in decreasing the concentrations of suspended sediment than were pollution-control strategies or other human activities. If streamflow had not decreased during the study period, it is unlikely that overall concentrations of suspended sediment would have decreased at many sites.

The streamflow and flow-adjusted trends in concentration for the period from 1993 to 2003 were placed in a longer context by comparing them to longer term, non-monotonic flow-adjusted trends in concentration for the period from 1985 to 2003 at a subset of the sites. From 1985 to 2003, streamflow generally decreased from about 1985 to 1991 , increased from about 1992 to 1996, and decreased from about 1997 to 2003. During the same period, many flow-adjusted trends in total nitrogen, nitrite plus nitrate, total phosphorus, orthophosphorus, and suspended-sediment concentrations occurred between 1985 and 1991 and between 1997 and 2003; unlike with streamflow, the direction of the flow-adjusted trends varied among sites and among time periods. These longer term, non-monotonic patterns indicated that consistent monotonic changes in streamflow and concentration may not have occurred through the entire period from 1993 to 2003, as indicated by the shorter term trend analysis.

The longer term patterns in streamflow also indicated that the decreasing streamflows observed from 1993 to 2003 in the Missouri River Basin likely will not continue indefinitely. In some parts of the basin, nutrient and suspended-sediment concentrations may have been higher without the decrease in streamflow and the associated decrease in surface runoff that occurred during the study period. Without additional steps to minimize surface runoff or nutrient loading on the land, it is possible that concentrations will increase when streamflow and runoff begin to increase once again. In addition, results from three case studies indicated that a substantial portion of the total flow and nitrate load in streams may consist of ground-water inflow in some parts of the basin. In these areas, nutrient loading to streams may be addressed by management practices focused not only on reducing surface runoff but also on maintaining and (or) improving ground-water quality.

\section{References Cited}

Adamski, J.C., Petersen, J.C., Freiwald, D.A., and Davis, J.V., 1995, Environmental and hydrologic setting of the Ozark Plateaus study unit, Arkansas, Kansas, Missouri, and Oklahoma: U.S. Geological Survey Water-Resources Investigations Report 94-4022, 69 p.

Akaike, H., 1981, Likelihood of a model and information criterion: Journal of Econometrics, v. 16, p. 3-14.

Bachman, L.J., Lindsey, Bruce, Brakebill, John, and Powars, D.S., 1998, Ground-water discharge and base-flow nitrate loads of nontidal streams, and their relation to a hydrogeomorphic classification of the Chesapeake Bay watershed, Middle Atlantic Coast: U.S. Geological Survey WaterResources Investigations Report 98-4059, 71 p.

Brown, C.E., 1998, Applied multivariate statistics in geohydrology and related sciences: Heidelberg, Germany, Springer-Verlag, 248 p.

Cohn, T.A., 1988, Adjusted maximum likelihood estimation of the moments of lognormal populations from type I censored samples: U.S. Geological Survey Open-File Report 88-350, $34 \mathrm{p}$.

Cohn, T.A., Gilroy, E.J., and Baier, W.G., 1992, Estimating fluvial transport of trace constituents using a regression model with data subject to censoring, in Proceedings of the Section on Statistics and the Environment, August 9-13, 1992, Boston, Massachusetts: American Statistical Association, p. 142-151.

Conservation Technology Information Center, 2006, Know your watershed, National Watershed Network, Muddy Creek: accessed March 30, 2006 at URL http://www.ctic. purdue.edu/cgi-bin/ShowWatershed.exe?Watershed=Muddy +Creek+\%28USGS\%23\%3A+10030104\%29

Crane, Kelly, 2005, Emergent sandbar habitat: University of Nebraska-Lincoln Water Center, Water Current, v. 37, no. 4, $16 \mathrm{p}$.

Creed, I.F., and Band, L.E., 1998, Export of nitrogen from catchments within a temperate forest -- evidence for a unifying mechanism regulated by variable source area dynamics: Water Resources Research, v. 34, no. 11, p. 3105-3120.

Denver Water, 2004, Snow pack (three year comparison) - reservoir levels and more: accessed April 1, 2004 at URL http://www.water.denver.co.gov/reslevelsmore/pdfs/snow_ pack.pdf. 
ESRI, 2005, ArcGIS, version 9.1: Redlands, Calif., ESRI.

Fenneman, N.M., and Johnson, D.W., 1946, Physiographic divisions of the conterminous United States: U.S. Geological Survey map, scale 1:7,000,000.

Frenzel, S.A., Swanson, R.B., Huntzinger, T.L., Stamer, J.K., Emmons, P.J., and Zelt, R.B., 1998, Water quality in the Central Nebraska Basins, Nebraska, 1992-95: U.S. Geological Survey Circular 1163, 33 p.

Fuller, W.A., 1996, Introduction to statistical time series, second edition: New York, John Wiley and Sons, 728 p.

Gburek, W.J., Drungil, C.C., Srinivasan, M.S., Needelman, B.A., and Woodward, D.E., 2002, Variable-source-area controls on phosphorus transport-bridging the gap between research and design: Journal of Soil and Water Conservation, v. 57 , no. 6 , p. 534-543.

Godberson, J.A., Zelt, R.B., and Zoller, A.L., 2006, Drainage areas for selected stream-sampling stations, Missouri River Basin: U.S. Geological Survey data available on the Web, accessed January 2006 at URL http://water.usgs.gov/lookup/ getspatial?NE-3071.

Helsel, D.R., 2005, Nondetects and data analysis-statistics for censored environmental data: New York, John Wiley and Sons, $250 \mathrm{p}$.

Helsel, D.R., and Hirsch, R.M., 1992, Statistical methods in water resources: Amsterdam, Elsevier, 529 p.

Huntzinger, T.L., and Ellis, M.J., 1993, Central Nebraska river basins, Nebraska: Water Resources Bulletin, v. 29, p. 533-574.

Insightful Corporation, 2002, S-PLUS ${ }^{\circledR} 6.1$ for Windows professional edition release 1, Insightful Corporation.

Leopold, L.B., Wolman, M.G., and Miller, J.P., 1964, Fluvial processes in geomorphology: New York, Dover Publications, $522 \mathrm{p}$.

Lindsey, B.D., Phillips, S.W., Donnelly, C.A., Speiran, G.K., Plummer, L.N., Bohlke, J.K., Focazio, M.J., Burton, W.C., and Busenberg, Eurybiades, 2003, Residence times and nitrate transport in ground water discharging to streams in the Chesapeake Bay watershed: U.S. Geological Survey Water-Resources Investigations Report 03-4035, 201 p.

Litke, D.W., and Kimbrough, R.A., 1998, Water-quality assessment of the South Platte River Basin, Colorado, Nebraska, and Wyoming - environmental setting and water quality of fixed sites, 1993-1995: U.S. Geological Survey Water-Resources Investigations Report 97-4220, 61 p.
Lower Missouri River Ecosystem Initiative, 1998, Lower Missouri River Ecosystem Initiative final report: Columbia, Missouri, U.S. Geological Survey Columbia Environmental Research Center, $20 \mathrm{p}$.

Miller, K.A., Clark, M.L., and Wright, P.R., 2005, Water-quality assessment of the Yellowstone River Basin, Montana and Wyoming — water quality of fixed sites, 1999-2001: U.S. Geological Survey Scientific Investigations Report 2004-5113, 82 p.

Missouri Department of Conservation, 2006, Pomme de Terre River watershed inventory and assessment: accessed March 30, 2006 at URL http://mdc.mo.gov/fish/watershed/pomme/ contents/330cotxt.htm.

Mueller, D.K., and Spahr, N.E., 2005, Water-quality, streamflow, and ancillary data for nutrients in streams and rivers across the Nation, 1992-2001: U.S. Geological Survey Data Series 152, available at URL http://pubs.usgs.gov/ ds/2005/152/.

Nakagaki, Naomi, and Wolock, D.M., 2005, Estimation of agricultural pesticide use in drainage basins using land cover maps and county pesticide data: U.S. Geological Survey Open-File Report 2005-1188, 46 p.

National Oceanic and Atmospheric Administration, 2002a, Climate of 2002 - Colorado drought. National Climatic Data Center: accessed on April 3, 2004 at URL http://lwf.ncdc.noaa.gov/oa/climate/ research/2002/jun/ st005dv00pcp200206.html.

National Oceanic and Atmospheric Administration, 2002b, Climate of 2002-annual review, U.S. drought. National Climatic Data Center: accessed on February 15, 2006 at URL http://www.ncdc.noaa.gov/oa/climate/research/2002/ ann/drought-summary.html.

National Oceanic and Atmospheric Administration, 2003, Climate of 2003-annual review, U.S. drought. National Climatic Data Center: accessed on February 15, 2006 at URL http://www.ncdc.noaa.gov/oa/climate/research/2003/ ann/drought-summary.html.

Natural Resources Conservation Service, 1994, State Soil Geographic (STATSGO) data base: U.S. Department of Agriculture, National Soil Survey Center, Miscellaneous Publication 1492, $110 \mathrm{p}$.

Natural Resources Conservation Service, 2006, Muddy Creek-one landowner's contribution to a cooperative effort: accessed March 30, 2006 at URL http://www. mt.nrcs.usda.gov/news/projects/muddycreek.html 
Oblinger Childress, C.J., Foreman, W.T., Connor, B.F., and Maloney, T.J., 1999, New reporting procedures based on long-term method detection levels and some considerations for interpretations of water-quality data provided by the U.S. Geological Survey National Water-Quality Laboratory: U.S. Geological Survey Open-File Report 99-193, 19 p.

Renard, K.G., Foster, G.R., Weesies, G.A., McCool, D.K., and Yoder, D.C., 1996, Predicting soil erosion by water-a guide to conservation planning with the revised universal soil loss equation (RUSLE): U.S. Department of Agriculture Handbook No. 703, 404 p.

Roth, M.S., 2005, Missouri River mainstem system is North America's largest reservoir system: University of NebraskaLincoln Water Center, Water Current, v. 37, no. 4, 16 p.

Ruddy, B.C., Lorenz, D.L., and Mueller, D.K., 2006, Countylevel estimates of nutrient inputs to the land surface of the conterminous United States, 1982-2001: U.S. Geological Survey Scientific Investigations Report 2006-5012, 17 p.

Runkel, R.L., Crawford, C.G., and Cohn, T.A., 2004, Load estimator (LOADEST) — a FORTRAN program for estimating constituent loads in streams and rivers: U.S. Geological Survey Techniques and Methods, book 4, chap. A5, 69 p.

Rutledge, A.T., 1998, Computer programs for describing the recession of ground-water discharge and for estimating mean ground-water recharge and discharge from streamflow records - update: U.S. Geological Survey Water-Resources Investigations Report 98-4148, 43 p.

Sando, S.K., and Neitzert, K.M., 2003, Water and sediment quality of the Lake Andes and Choteau Creek Basins, South Dakota, 1983-2000: U.S. Geological Survey WaterResources Investigations Report 03-4148, 114 p.

SAS Institute Inc., 2004, SAS OnlineDoc ${ }^{\circledR}$ 9.1.2: Cary, NC, SAS Institute Inc.

Schumm, S.A., 1977, The fluvial system: New York, Wiley and Sons, $338 \mathrm{p}$.

Schwarz, G.E., Smith, R.A., Alexander, R.B., and Gray, J.R., 2001, A spatially referenced regression model (SPARROW) for suspended sediment in streams of the conterminous U.S., in Proceedings of the Seventh Federal Interagency Sedimentation Conference, March 25-29, 2001, Reno, Nevada: U.S. Subcommittee on Sedimentation, p. VII-80-87.

Soil Conservation Service, 1983, National engineering handbook-section 3, sedimentation: U.S. Department of Agriculture National Engineering Handbook, 226 p.

Trench, E.C.T., 2004, Analysis of phosphorus trends and evaluation of sampling designs in the Quineburg River Basin, Connecticut: U.S. Geological Survey Scientific Investigations Report 2004-5094, 18 p.
Trench, E.C.T., and Vecchia, A.V., 2002, Water-quality trend analysis and sampling design for streams in Connecticut, 1968-98: U.S. Geological Survey Water-Resources Investigations Report 02-4011, 94 p.

Trimble, S.W., 1997, Contribution of stream channel erosion to sediment yield from an urbanizing watershed: Nature, v. 278 , no. 5342 , p. 1,442-1,444.

Trimble, S.W., and Crosson, Pierre, 2000, U.S. soil erosion rates-myth and reality: Science, v. 289, p. 248-250.

U.S. Army Corps of Engineers, 2006, 2006 mountain snowpack report for Missouri River Basin: U.S. Army Corps of Engineers Missouri River Region Mountain Snowpack Report: accessed on February 15, 2006 at URL http://www. nwd-mr.usace.army.mil/rcc/reports/snwpck.html.

U.S. Census Bureau, 1991, Census of population and housing, 1990: U.S. Census Bureau Technical Documentation Public Law 94-171, digital tabular data on CD-ROM: accessed on January 23, 2006 at URL http://www.census.gov/main/ www/cen 1990.html.

U.S. Census Bureau, 2000, Census 2000 redistricting data summary file: U.S. Census Bureau Technical Documentation Public Law 94-171, 223 p.

U.S. Department of Agriculture, 1995, National resources inventory [CD-ROM reissued May 1995]: Washington, D.C., Natural Resources Conservation Service, and Ames, Iowa, Statistical Laboratory, Iowa State University.

U.S. Department of Agriculture, 2001, 1997 National resources inventory (revised December 2000) [CD-ROM, version 1]: Washington, D.C., Natural Resources Conservation Service, and Ames, Iowa, Statistical Laboratory, Iowa State University.

U.S. Geological Survey, 1992, Analytical methods-discontinuation of the National Water-Quality Laboratory determinations for "total" nitrite, "total" nitrite plus nitrate, "total" ammonia, and "total" orthophosphorus (using the fourchannel analyzer): U.S. Geological Survey Office of Water Quality Technical Memorandum 93.04, 5 p.

U.S. Geological Survey, 1997, Change in ammonia minimum reporting limit: U.S. Geological Survey National WaterQuality Laboratory Technical Memorandum 97-10, 2 p.

U.S. Geological Survey, 2005, Elevation derivatives for national applications (EDNA): accessed on February 15, 2006 at URL http://edna.usgs.gov.

Vecchia, A.V., 2000, Water-quality trend analysis and sampling design for the Souris River, Saskatchewan, North Dakota, and Manitoba: U.S. Geological Survey WaterResources Investigations Report 00-4019, 77 p. 
Vecchia, A.V., 2003, Water-quality trend analysis and sampling design for streams in North Dakota, 1971-2000: U.S. Geological Survey Water-Resources Investigations Report 03-4094, 73 p.

Vecchia, A.V., 2005, Water-quality trend analysis and sampling design for streams in the Red River of the North Basin, Minnesota, North Dakota, and South Dakota, 1970-2001: U.S. Geological Survey Scientific Investigations Report 2005-5224, 54 p.

Vogelmann, J.E., Howard, S.M., Yang, L., Larson, C.R., Wylie, B.K., and Van Driel, N., 2001, Completion of the 1990s National Land Cover Data Set for the conterminous United States from Landsat Thematic Mapper Data and ancillary data sources: Photogrammetric Engineering and Remote Sensing, v. 67, p. 650-652.

Walling, D.E., 1983, The sediment delivery problem: Journal of Hydrology, v. 65, p. 209-237.

Williams, G.P., and Wolman, M.G., 1984, Downstream effects of dams on alluvial rivers: U.S. Geological Survey Professional Paper 1286, 83 p.

Winter, T.C., 2001, The concept of hydrologic landscapes: Journal of the American Water Resources Association, v. 37, p. 335-349.

Wolock, D.M., 2003, Hydrologic landscape regions of the United States: U.S. Geological Survey Open-File Report 03-145, digital data set: accessed on January 23, 2006 at URL http://water.usgs.gov/lookup/getspatial?hlrus.

Zelt, R.B., Boughton, G.K., Miller, K.A., Mason, J.P., and Gianakos, L.M., 1999, Environmental setting of the Yellowstone River Basin, Montana, North Dakota, and Wyoming: U.S. Geological Survey Water-Resources Investigations Report 98-4269, 112 p. 


\section{Appendixes}




\section{Appendix 1. Description of methods used to derive estimates of nitrogen loading from point sources}

Monitoring data from permitted dischargers in the Missouri River Basin from 1993 to 2003 were obtained from the U.S. Environmental Protections Agency Permit Compliance System. For each unique record, fields for the facility name and address, the monitoring location at the facility, the monitoring period end date, concentrations and (or) load for all available nutrient species, quantity of discharge, and permit limits for discharge and concentrations and (or) load were requested.

- A series of data screens were used to identify records with insufficient or incorrect information. Records with a monitoring location involving discharge to ground water were excluded.

- If measurement units were missing for concentration, load, or discharge, permit units were adopted; when both were missing, the record was excluded. Assumptions could not be made due to the wide variety of reported units in the data set.

- Both right and left censored values were set to the censoring level.

- If the discharge was greater than 50 times the reported design capacity of the facility, the value was excluded.

- If facility location information was not sufficient to identify the receiving water, the record was excluded.

- If no date was associated with the record, it was excluded.

Values for the load associated with each record were used as reported when available. When load was not reported, it was calculated by multiplying the reported concentration by the reported discharge using an appropriate unit conversion factor. These instantaneous loads were converted to mass by multiplying by the number of days between that monitoring date and the preceding monitoring date. When the reporting interval was less than a year, an annual mass was calculated by summing the mass values within each year. When the reporting interval began in one year and ended in the next, the mass was proportionately split between the two years. When the reporting interval exceeded one year, the data were excluded. The assumption that the instantaneous load was representative of conditions during the entire reporting period likely was incorrect and may have led to substantial over- or underestimation of annual mass.

GIS was used for spatial overlay analyses of the drainage areas with digital thematic maps of the annual mass values for each constituent. If there were no location coordinates for a facility, the address of the facility's office was used to obtain location coordinates; occasionally, only the city name was available from the office address. As a result, the final coordinates may not reflect the actual discharge location. These estimated locations, however, likely were sufficient for identifying the facilities in the drainage area of each site.

The data then were examined for temporal and spatial coverage by constituent. Coverage of all phosphorus constituents was poor; therefore, these data were not used. The nitrogen constituent with the best coverage was ammonia; ammonia data were used in this report, and total nitrogen was used at a small number of locations to fill in spatial gaps where ammonia data were not available. The predominance of ammonia data likely means that overall nitrogen loading from point sources was underrepresented in many locations. For the analyses in this report, the bias introduced by combining ammonia and total nitrogen data likely was smaller than any bias resulting from the exclusion of all data from facilities only reporting total nitrogen. The annual nitrogen mass values within the drainage area of each site were summed. The summed annual mass values then were converted to annual yields by dividing by the drainage area of each site.

During the processing of these data, about 50 percent of the records ultimately were excluded. Most were excluded because the records were not complete. The effect of these missing data on the nitrogen yield estimates is unknown but is likely substantial. 


\section{Appendix 2. Custom algorithm used to extract a target percentage of the total drainage area}

/* dasubset.aml Ronald B. Zelt 02/02/2006

/* Purpose:

/* Produce grid \& coverage as <output $>$ that represents the areal extent of $<$ percentage $>$

$/ *$ percent of a drainage area that is closest to the watershed outlet (pour point),

$/ *$ as measured along flow-direction paths. Typically, $<$ percentage $>$ would be

/* set to smaller values as <drainage_area $>$ becomes larger, because <output $>$ is

$/ *$ intended to represent the area of greatest influence on the water quality at the

$/ *<$ staid $>$ point.

/* Typical values of $<$ percentage $>$ range from 10 to 15 minus the base- 10 logarithm of

$/ *<$ drainage_area $>$; e.g. for a 1000 sq. mi. drainage, $7<<$ percentage $><12$ is usual.

$1 *$

/* Outputs:

/* Output data sets created for the extent of $<$ flowdirection_grid $>$ :

/* Flow accumulation : FA_\%staid\%

/*

$1 *$ Output data sets created for the extent of $<$ drainage area $>$ :

/* Watershed mask : WS_\%staid\%

/* Flow length : FL100_\%staid\%

/*

$1 *$ Output data sets created for the "most proximal" \%pct\% percent of drainage area :

/* Flow length : FL\%pct\%_\%staid\%

/* Extent of subset : LO\%pct\%_\%staid\% and LP\%pct\%_\%staid\%

$/ *$

/* An ESRI watch file named DAS_<staid $>_{-}<$pct $>$_ $<$opt $>$. wat will be created to record much of

$/ *$ the dialog.

$/ *$

/* Arguments:

$/ *<$ flowdirection_grid $>$ - a flow direction grid, presumed to be correct hydrologically,

$I^{*}$ using the standard ESRI encoding of vector direction as would result from the

* FLOWDIRECTION function.

$/ *<$ staid $>$ - station ID code to be used in constructing names of output grids; if an

/* 8-digit code is supplied, only digits 3-8 will be used; otherwise, digits 1-6

$/ *$ will be used. The full $<$ staid $>$ is used to populate polygon attribute STAID.

$1 *<$ sLat $><$ sLong $>$ - coordinates of point on/near stream for which $<$ output $>$ is desired.

$1 *<$ drainage_area $>$ - area, in square miles, drained by stream at $<$ staid $>$ point.

$/ *<$ percentage $>$ - percentage of $<$ drainage_area $>$ to represent in output extents.

$/ *<$ FULL $\mid$ REDO $>$

/* FULL - option for full processing of flow direction grid to production flow

$1^{*}$ accumulation, watershed extent grid, and flowlength grid, followed by iterative

$1 * \quad$ analysis to find $<$ output $>$.

/* REDO - option for using existing intermediate grids produced by previous run with

/* FULL option, and proceeding directly to iterative analysis to find <output>.

/* The existing intermediate grids needed for the REDO option are the watershed and

/* flowlength grids (WS_\%staid\% FL100_\%staid\% FL\%pct\%_\%staid\%).

/*

$/ *\{$ da_boundary_cover $\}$ - optional coverage showing the drainage basin boundary(ies),

$I^{*}$ used only for reference in screen display.

$/ *$

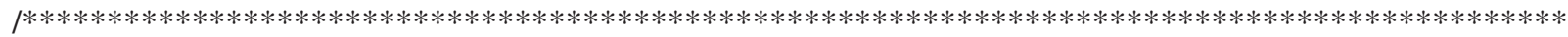

\&args fdirg fullstaid slat slong darea pct opt dabdy:rest

\&s hdr DASUBSET - version 1.1.2 - USGS July 11, 2005 
\&if [null \%opt\%] \&then \&return Usage: DASUBSET $<$ flowdirection_grid $><$ staid $><$ sLat $><$ sLong $><$ drainage_area $><$ percentage $><$ FULL $\mid$ REDO $>$ da_boundary_cover $\}$

\&select $\%$ opt $\%$

\&when FULL, full

\&s opt [upcase [unquote \%opt\%]]

\&when REDO, redo

\&s opt [upcase [unquote \%opt\%]]

\&otherwise

\&return Usage: DASUBSET $<$ flowdirection_grid $><$ staid $><$ sLat $><$ sLong $><$ drainage_area $><$ percentage $>\{$ FULL $\mid$

REDO $\{$ da_boundary_cover

\&end

\&if not [exists \%fdirg\% -grid] \&then \&return Grid \%fdirg\% not found.

\&if $\%$ pct $\%$ lt 1 or $\%$ pct $\%$ gt 99 \&then \&return Value for <percentage> is out of range: \%pct\%

/*

/********* ESTABLISH PARAMETERS OF ANALYSIS ************

/*

\&if [null \%dabdy\%] \&then \&s dabdy none

\&if not [exists \%dabdy\% -cover] \&then \&s dadraw [unquo "]

\&else \&s dadraw arcs \%dabdy $\%$

/* extract the part of <staid > to use in data-set names:

\&s staid \%fullstaid $\%$

\&if [length \%fullstaid\%] eq 8 \&then \&s staid [substr \%fullstaid\% 3 6]

\&if [length \%fullstaid\%] gt 8 \&then \&s staid [substr \%staid\% 16 ]

\&s da10pctmi $2=[$ calc $\%$ darea $\% * \%$ pct $\% / 100]$

$\&$ s da10pctm $2=[$ calc $\%$ da10pctmi $2 \% * 2.59 * 1000000] / *$ convert sq. mi. to sq. meters.

/*

/* Determine the target number of grid cells that corresponds to the desired subset area:

/*

\&if [show program] eq ARC \&then grid

\&describe $\%$ fdirg $\%$

\&s fdirg \%grd\$full_grid\%

\&if \% prj\$units\% eq DD \& then \&do

\&if [truncate [calc $3600 * \% \operatorname{grd} \$ \mathrm{dx} \% * 10000]$ ] eq $10000 \&$ then $\&$ s da10pctcells $=[$ calc $\%$ da10pctm2\% / 900] $/ * 1-\operatorname{arc}-\mathrm{second}$ DEM

\&if [truncate [calc $3 * 3600 * \% \operatorname{grd} \$ \mathrm{dx} \% * 10000]$ ] eq $10000 \&$ then \&s da10pctcells $=$ [calc $\%$ da10pctm2\% / 100] $/ *$ thirdarc-second DEM

\&end

\&else \&if \%prj\$units\% eq METERS \&then \&do

$\&$ s da10pctcells $=[$ calc $\%$ da10pctm $2 \% /(\% \operatorname{grd} \$ \mathrm{dx} \% * \% \operatorname{grd} \$ \mathrm{dx} \%)]$

\&end

\&else \&return Unexpected map units.

\&s da10pctcells [truncate \%da10pctcells\%]

$/ *$

/************* Report to user. $* * * * * * * * * * * *$

/*

\&watch DAS_\%staid\%_\%pct\%_\%opt\%.wat

\&type [date -vfull]

\&type \%hdr\%

\&type Setup for processing flowdirection_grid \%fdirg\%

\&type $>$ Subset will be \%pct\% percent of the drainage area.

\&type $>$ Drainage area subset : \%da10pctmi2\% sq. mi.

\&type $>$ Drainage area subset : \%da10pctm $2 \%$ sq. meters 
\&type $>$ Drainage area subset : \%da10pctcells\% grid cells

\&type

disp 9999

/* mape \%fdirg\%

shadeset rainbow

lineset plotter; linesym 5

markerset water; markersym 425; markersize .15

units map

gridsh \%fdirg\% \# linear

$\%$ dadraw\%

marker \%slong\% \%slat $\%$

reset

\&type Select area for viewing proximal \%pct\% percent of drainage area.

setwindow *

\&s awindow [show setwindow]

reset

clear

mape \%awindow\%

\&if \%opt\% eq REDO \&then \&goto SHORT

/*

/************ REDO processing omits the following sections $* * * * * * * * * * * * * * * * *$

/*

gridsh \%fdirg\% \# linear

$\%$ dadraw $\%$

marker \%slong $\% \%$ slat $\%$

$1 *$ Compute FLOW ACCUMULATION .

\&if not [exists FA_\%staid\% -grid] \&then FA_\%staid\% = flowaccumulation(\%fdirg\%)

\&type

\&describe FA_\%staid\%

\&setvar a [calc \%slong $\%-10 * \% \operatorname{grd} \$ \mathrm{dx} \%$ ]

\&setvar b [calc \%slong $\%+10 * \% \operatorname{grd} \$ \mathrm{dx} \%$ ]

\&setvar c [calc \%slat $\%-10 * \% \operatorname{grd} \$ \mathrm{dx} \%$ ]

$\&$ setvar d [calc $\%$ slat $\%+10 * \% \operatorname{grd} \$ \mathrm{dx} \%$ ]

gridsh FA_\%staid\% \# linear

$\%$ dadraw $\%$

line $\% \mathrm{a} \% \%$ slat $\% \% \mathrm{~b} \% \%$ slat $\%$

line $\%$ slong $\% \%$ c $\% \%$ slong $\% \% \mathrm{~d} \%$

/* Give the user opportunities to define a suitably zoomed view of the synthetic drainage.

markersize 0.05

\&s ok .FALSE.

\&do \&until \%ok\%

\&s v1 [response 'Create zoom window on stream station. Then press ENTER' -noecho]

gridsh FA_\%staid\% \# linear

$\%$ dadraw $\%$

line $\% \mathrm{a} \% \%$ slat $\% \% \mathrm{~b} \% \%$ slat $\%$

line $\%$ slong $\% \% \mathrm{c} \% \%$ slong $\% \% \mathrm{~d} \%$

\&s ok [query 'Is the zoom window you created okay'.TRUE.]

\&end

/* User points to location on synthetic drainage that corresponds to sampling station:

gridsh FA_\%staid\% \# linear

$\%$ dadraw $\%$

line $\% \mathrm{a} \% \%$ slat $\% \% \mathrm{~b} \% \%$ slat $\%$ 
line $\%$ slong $\% \% \mathrm{c} \% \%$ slong $\% \% \mathrm{~d} \%$

\&type !!! CRITICAL STEP: Enter location of stream station on the synthetic stream network now displayed.

\&s ok .FALSE.

\&do \&until \%ok\%

\&getpoint \&map \&mouse

cell FA_\%staid\% \%pnt\$x\% \%pnt\$y\%

\&s ok [query 'Is the cell location you entered okay' .TRUE.]

\&end

$\&$ s len $=100 * \% \operatorname{grd} \$ \mathrm{dx} \%$

\&setvar a \%pnt $\$ \mathrm{x} \%$ - \%len $\%$

\&setvar b \%pnt\$y $\%$ - \%len $\%$

\&setvar c \%pnt $\$ \mathrm{x} \%+\%$ len $\%$

\&setvar d \%pnt\$y\% + \%len\%

gridsh FA_\%staid\% \# linear

$\%$ dadraw $\%$

markersize 0.02

marker $\%$ slong $\% \%$ slat $\%$

\&if [exists WS_\%staid\% -grid] \&then kill WS_\%staid\%

WS_\%staid $\%=$ watershed(\%fdirg\%, selectpoint(FA_\%staid $\%, \%$ pnt\$x $\%, \%$ pnt\$y $\%)) \quad / *$ DELIMIT WATERSHED

\&type

$/ *$ list WS_\%staid\%.vat /* debug

gridsh WS_\%staid\%

$\%$ dadraw $\%$

line $\%$ a $\% \%$ pnt $\$ y \% \%$ c\% $\%$ pnt\$y $\%$

line $\%$ pnt $\$ \mathrm{x} \% \% \mathrm{~b} \% \%$ pnt $\$ \mathrm{x} \% \% \mathrm{~d} \%$

setmask WS_\%staid\%

/* ESTABLISH PROCESSING MASK

\&if [exists FL100_\%staid\% -grid] \&then kill FL100_\%staid\%

FL100_\%staid $\%=$ flowlength $(\%$ fdirg $\%$, \#, downstream $) \quad / *$ Compute FLOW LENGTH .

\&type

markersize 0.02

marker $\%$ slong\% \%slat $\%$

/*

/************ REDO processing resumes $* * * * * * * * * * * * * * * * *$

/*

\&label SHORT

setmask WS_\%staid\%

/* ESTABLISH PROCESSING MASK

\&type Drawing results from FLOWLENGTH analysis ...

gridsh FL100_\%staid\% \# linear

$\%$ dadraw\%

shadeset contrast

/* set analysis window for iterations:

line [calc $\%$ slong $\%$ - $40 * \% \operatorname{grd} \$ \mathrm{dx} \%$ ] $\%$ slat $\%$ [calc $\%$ slong $\%+40 * \% \operatorname{grd} \$ \mathrm{dx} \%$ ] $\%$ slat $\%$

line $\%$ slong $\%$ [calc $\%$ slat $\%-40 * \%$ grd $\$ \mathrm{dx} \%$ ] $\%$ slong $\%$ [calc $\%$ slat $\%+40 * \% \operatorname{grd} \$ \mathrm{dx} \%$ ]

\&type !!! CRITICAL step: Select ANALYSIS AREA for processing proximal \%pct\% percent of drainage area.

setwindow *

/* ESTABLISH PROCESSING WINDOW

\&mess \&off

\&if [exists LO\%pct\%_\%staid\% -grid] \&then kill LO\%pct\%_\%staid\% all

LO\%pct\%_\%staid $\%=\operatorname{int}\left(1+\mathrm{WS} \_\%\right.$ staid $\left.\% * 0\right) \quad / *$ initial area, as integer grid 
\&describe LO\%pct\%_\%staid\%

\&s testval [show select LO\%pct\%_\%staid\%.vat info 1 item count] $/ *$ store initial area (in grid cells)

\&if [exists FL\%pct\%_\%staid\% -grid] \&then kill FL\%pct\%_\%staid\%

FL\%pct\%_\%staid\% = FL100_\%staid\% $\quad / *$ create subset of flowlength grid.

\&describe FL\%pct\%_\%staid\%

\&s maxleng $\% \operatorname{grd} \$ z \max \%$

\&s minleng \% grd $\$$ zmin $\%$

\&s newleng \% maxleng\%

\&s lastleng \% maxleng $\%$

\&s secleng 1

\&type \%newleng\% (\%prj\$units\%) is maximum flowpath length.

\&s critarea \%da10pctcells\%

\&s lastfact $=1$

\&s lastval $=0$

$\&$ s ok $=1.25$

$\& \mathrm{~s} \mathrm{k}=0$

\&mess \&on

/*******************************************************************************************

$/ *$ begin loop to iterate toward the area that is $<$ percentage $>$ percent of total drainage area

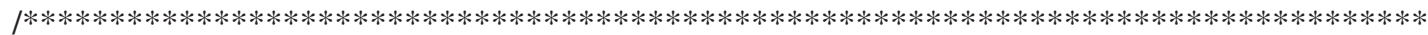

/*

\&do \&until \%ok\% gt 0.99 AND \%ok\% lt $1.01 \quad / *$ within 1 percent of target size

$\& \mathrm{~s} \mathrm{k}=\% \mathrm{k} \%+1$

$\&$ fact $=[$ calc $[$ abs $[$ calc $1-\%$ ok\%] $] / 2]$

\&if \% fact $\%$ gt $0.95 \&$ then \&s fact $=0.95 \quad / *$ prevent a negative length criterion.

\&if $\%$ ok\% lt 1 \&then \&s newleng = [calc \%lastleng\% $\%$ fact $\% * \%$ lastleng $\%$ ]

$/ *$

\&else \&s newleng $=$ [calc \%lastleng $\%$ - \% fact $\% * \%$ lastleng $\%$ ]

$1^{*}$ In case iteration somehow starts alternating between the same values:

\&if \%newleng\% eq \%secleng\% \&then \&s newleng = [calc \%newleng\% * .98]

$1 *$ Prevent a length criterion from producing null grid as CON output.

\&if \%newleng\% lt \% minleng\% \& then \&s newleng = [calc \% minleng $\% * 50$ ]

/* For the first approximation, use maximum flow length:

\&if $\% \mathrm{k} \%$ eq 1 \&then \&s newleng \% maxleng\%

\&type \%newleng\% is trial length for iteration $\% \mathrm{k} \% \quad / *$ debug

/*

I* Create the subset and calculate the number of grid cells it contains:

\&mess \&off

\&if [exists LO\%pct\%_\%staid\% -grid] \&then kill LO\%pct\%_\%staid\% all

LO \%pct\%_\%staid $\%=$ con(FL\%pct\%_\%staid\%<\%newleng\%, \%k\%)

$\&$ describe LO\%pct\%_\%staid\%

\&mess \&on

\&if [exists LO\%pct\%_\%staid\%.vat -info] \&then \&do

\&s testval [show select LO\%pct\%_\%staid\%.vat info 1 item count]

/* Compare the number of grid cells in the subset with the target number:

\&s ok [calc \%testval\% / \%critarea\%]

\&type Iteration $\% \mathrm{k} \%$ area (grid cells $)=\%$ testval $\%$, or $\%$ ok $\%$ of target size

\&end $/ *$ then do

\&else \&do

$\&$ s testval $=0 / *$ no VAT presumably because null grid resulted from CON test.

\&s ok $=0$

\&type Iteration $\% \mathrm{k} \%$ area (grid cells) $=\%$ testval $\%$, or $\%$ ok $\%$ of target size 
$\&$ s ok $=2 / *$ prepare for next iteration using a test length of one-one-half maxlength. \&s lastleng \%maxleng\%

\&end

\&type

/* Checks to prevent perpetual loops.

\&if \%lastval\% eq \% testval\% \& then \&return !!! FAILURE to converge. Analysis area likely is too small.

\&if $\% \mathrm{k} \%$ gt 15 \& then \&return !!! FAILURE to converge on target area.

\&s lastfact $=\%$ fact $\%$

\&s lastval $=\%$ testval $\%$

\&s secleng $=\%$ lastleng $\%$

\&s lastleng $=\%$ newleng $\%$

\&end $/ *$ do until

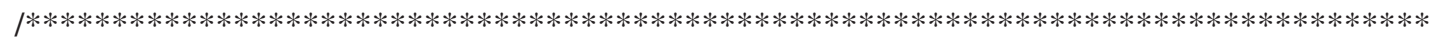

\&type TARGET ACQUIRED!!!

gridsh LO\%pct\%_\%staid\%

$\%$ dadraw $\%$

\&mess \&off

\&if [exists LP\%pct\%_\%staid\% -cover] \&then kill LP\%pct\%_\%staid\%

\&mess \&on

/* VECTORIZE CHIEF OUTPUT.

$\mathrm{LP} \%$ pct\%_\%staid\% = gridpoly $(\mathrm{LO} \%$ pct\%_\%staid\% $)$

\&mess \&off

arc tables

additem LP\%pct\%_\%staid\%.PAT STAID $1515 \mathrm{C}$

sel LP\%pct\%_\%staid\%.PAT

res area gt 0 and grid-code gt 0

move [quote \%fullstaid\%] to STAID $\quad / *$ store STAID as polygon attribute.

q

\&mess \&on

\&type

\&type Output files successfully created :

\&if \%opt \% eq FULL \& then \&do

\&type $>$ Flow accumulation : FA_\%staid\%

$\log$ FA_\%staid\% add

DASUBSET \%fdirg\% \% fullstaid $\% \%$ slat $\% \%$ slong $\% \%$ darea $\% \%$ pct $\% \%$ opt $\% \%$ dabdy $\%$

\&type $>$ Watershed mask : WS_\%staid\%

log WS_\%staid\% add

DASUBSET \%fdirg\% \%fullstaid \% \%slat \% \%slong \% \%darea\% \%pct\% \%opt \% \%dabdy \%

\&type $>$ Flow length : FL100_\%staid\%

$\log$ FL100_\%staid\% add

DASUBSET \%fdirg\% \%fullstaid \% \%slat \% \%slong \% \%darea\% \%pct \% \%opt \% \%dabdy \%

\&end

\&type $>$ Flow length $\quad$ : FL\%pct\%_\%staid\%

$\log$ FL\%pct\%_\%staid\% add

DASUBSET $\%$ fdirg $\% \%$ fullstaid $\% \%$ slat $\% \%$ slong $\% \%$ darea $\% \%$ pct $\% \%$ opt $\% \%$ dabdy $\%$

\&type > Extent of subset : LO\%pct\%_\%staid\% and LP\%pct\%_\%staid\%

$\log$ LO\%pct\%_\%staid\% add

DASUBSET \%fdirg \% \%fullstaid \% \%slat \% \%slong $\% \%$ darea $\% \%$ pct $\% \%$ opt $\% \%$ dabdy $\%$

$\log$ LP\%pct\%_\%staid\% add 
DASUBSET \%fdirg\% \% fullstaid $\% \%$ slat $\% \%$ slong $\% \%$ darea $\% \%$ pct $\% \%$ opt $\% \%$ dabdy $\%$

\&type ----------| Adios, Amigo |-

\&type DASUBSET \%fdirg\% \%fullstaid\% \%slat \% \%slong\% \%darea\% \%pct\% \%opt\% \%dabdy\%

\&type

\&type [date -vfull]

\&w \&off

\&return 
64 Nutrient and Suspended-Sediment Trends in the Missouri River Basin, 1993-2003

Appendix 3. Model output for trends in mean monthly streamflow from 1993 to 2003

\begin{tabular}{|c|c|c|c|c|}
\hline $\begin{array}{c}\text { Site } \\
\text { number } \\
\text { (fig. 1) }\end{array}$ & $\begin{array}{l}\text { U.S. Geological } \\
\text { Survey } \\
\text { station number }\end{array}$ & $\begin{array}{c}\text { Reference } \\
\text { streamflow, in } \\
\text { cubic meters per } \\
\text { second }\end{array}$ & $\begin{array}{l}\text { Trend slope, in } \\
\text { cubic meters } \\
\text { per second } \\
\text { per year }\end{array}$ & $\begin{array}{c}p- \\
\text { value }^{1}\end{array}$ \\
\hline 1 & 06088500 & 1.8 & 0.0102 & 0.3686 \\
\hline 2 & 06089000 & 10 & -0.501 & $<0.0001$ \\
\hline 3 & 06115200 & 190 & -13 & $<0.0001$ \\
\hline 4 & 06130500 & 2 & -0.57 & $<0.0001$ \\
\hline 5 & 06154410 & 0.048 & -0.00396 & $<0.0001$ \\
\hline 11 & 06274300 & 36 & -2.05 & $<0.0001$ \\
\hline 17 & 06329500 & 220 & -13.8 & $<0.0001$ \\
\hline 18 & 06338490 & 560 & 1.02 & 0.8397 \\
\hline 19 & 06341410 & 0.28 & -0.00736 & 0.0345 \\
\hline 20 & 06341800 & 0.37 & -0.0311 & 0.0075 \\
\hline 21 & 06436180 & 0.51 & -0.0334 & $<0.0001$ \\
\hline 22 & 06441500 & 0.57 & -0.0762 & 0.0016 \\
\hline 23 & 06452000 & 9.5 & -0.688 & 0.0098 \\
\hline 24 & 06461500 & 22 & -0.139 & 0.1568 \\
\hline 25 & 06463500 & 5.2 & -0.0623 & 0.0015 \\
\hline 26 & 06468250 & 0.4 & -0.00255 & 0.9105 \\
\hline 28 & 06713500 & 0.68 & 0.036 & 0.0309 \\
\hline 29 & 06714000 & 5.1 & -0.0181 & 0.6692 \\
\hline 33 & 06752260 & 0.99 & -0.0275 & 0.0621 \\
\hline 34 & 06752280 & 0.31 & -0.0113 & 0.0232 \\
\hline 35 & 06753990 & 0.11 & -0.0459 & $<0.0001$ \\
\hline 36 & 06754000 & 21 & -0.696 & 0.0050 \\
\hline 37 & 06758500 & 13 & -0.363 & 0.0183 \\
\hline 39 & 06775900 & 6.2 & 0.0326 & 0.0028 \\
\hline 40 & 06800000 & 1.8 & -0.17 & $<0.0001$ \\
\hline 42 & 06805500 & 210 & -14.4 & $<0.0001$ \\
\hline 43 & 06817700 & 8.5 & -1.75 & $<0.0001$ \\
\hline 44 & 06818000 & 1,300 & -72 & $<0.0001$ \\
\hline 51 & 06902000 & 32 & -6.32 & $<0.0001$ \\
\hline 52 & 06905500 & 16 & -2.82 & $<0.0001$ \\
\hline 53 & 06921070 & 2.4 & -0.231 & 0.0037 \\
\hline 55 & 06926510 & 180 & -30.9 & $<0.0001$ \\
\hline 57 & 06930800 & 29 & -2.72 & $<0.0001$ \\
\hline 58 & 06934500 & 2,400 & -226 & $<0.0001$ \\
\hline
\end{tabular}

'Significant trend if $p$-value less than 0.05 . 
Appendix 4. Model output for flow-adjusted trends in concentration from 1993 to 2003

[CI, confidence interval; --, poor model fit; $\mathrm{R}^{2}$, coefficient of determination between observed and predicted concentrations; significant trend if $\mathrm{p}$-value less than 0.05 ]

\begin{tabular}{|c|c|c|c|c|c|c|c|c|c|c|c|c|c|c|}
\hline \multirow[b]{2}{*}{$\begin{array}{c}\text { Site } \\
\text { num- } \\
\text { ber } \\
\text { (fig. 1) }\end{array}$} & \multirow[b]{2}{*}{$\begin{array}{c}\text { U.S. } \\
\text { Geologi- } \\
\text { cal Survey } \\
\text { station } \\
\text { number }\end{array}$} & \multirow{2}{*}{$\begin{array}{c}\text { Refer- } \\
\text { ence } \\
\text { concen- } \\
\text { tration, } \\
\text { in } \\
\text { milli- } \\
\text { grams } \\
\text { per liter }\end{array}$} & \multicolumn{3}{|c|}{$\begin{array}{c}\text { Trend, in percent } \\
\text { per year }\end{array}$} & \multicolumn{4}{|c|}{$\begin{array}{c}\text { Properties of the calibration } \\
\text { data set }\end{array}$} & \multicolumn{3}{|c|}{$\begin{array}{c}\text { Properties of the modeled } \\
\text { time term }\end{array}$} & \multicolumn{2}{|c|}{$\begin{array}{l}\text { Properties of } \\
\text { the fitted model }\end{array}$} \\
\hline & & & $\begin{array}{l}\text { Model- } \\
\text { ed } \\
\text { esti- } \\
\text { mate }\end{array}$ & $\begin{array}{l}\text { Upper } \\
95- \\
\text { percent } \\
\text { CI }\end{array}$ & $\begin{array}{l}\text { Lower } \\
\text { 95- } \\
\text { percent } \\
\text { CI }\end{array}$ & $\begin{array}{l}\text { Start } \\
\text { date }\end{array}$ & $\begin{array}{l}\text { End } \\
\text { date }\end{array}$ & $\begin{array}{c}\text { Num- } \\
\text { ber } \\
\text { of } \\
\text { observ- } \\
\text { ations }\end{array}$ & $\begin{array}{c}\text { Num- } \\
\text { ber of } \\
\text { cens- } \\
\text { ored } \\
\text { observ- } \\
\text { ations }\end{array}$ & $\begin{array}{l}\text { Coeff- } \\
\text { icient }\end{array}$ & $\begin{array}{l}\text { Standard } \\
\text { deviation }\end{array}$ & $\begin{array}{c}p- \\
\text { value }\end{array}$ & $\begin{array}{l}\text { Residual } \\
\text { variance }\end{array}$ & $\mathbf{R}^{2}$ \\
\hline \multicolumn{15}{|c|}{ Total nitrogen } \\
\hline 6 & 06178000 & 0.660 & 0.9 & 3.5 & -1.6 & $10 / 15 / 1992$ & $8 / 13 / 2003$ & 53 & 0 & 0.0088 & 0.0126 & 0.4605 & 0.0739 & 99 \\
\hline 17 & 06329500 & 0.567 & 4.0 & 7.8 & 0.4 & 10/8/1992 & $9 / 9 / 2003$ & 113 & 1 & 0.0396 & 0.0178 & 0.0245 & 0.2294 & 82 \\
\hline 18 & 06338490 & 0.283 & 3.1 & 8.1 & -1.6 & 10/6/1992 & $8 / 28 / 2003$ & 61 & 0 & 0.0308 & 0.0236 & 0.1842 & 0.3173 & 39 \\
\hline 24 & 06461500 & 0.427 & 4.9 & 8.4 & 1.5 & 10/7/1992 & $9 / 9 / 2003$ & 68 & 0 & 0.0474 & 0.0164 & 0.0037 & 0.1963 & 63 \\
\hline 25 & 06463500 & -- & -- & -- & -- & -- & -- & -- & -- & -- & -- & -- & -- & -- \\
\hline 26 & 06468250 & 1.505 & 0.5 & 3.0 & -1.9 & $11 / 23 / 1992$ & $8 / 25 / 2003$ & 86 & 0 & 0.0049 & 0.0123 & 0.6819 & 0.1225 & 98 \\
\hline 28 & 06713500 & 2.724 & -6.8 & 1.5 & -14.4 & 4/12/1993 & $9 / 22 / 2003$ & 96 & 0 & -0.0703 & 0.0431 & 0.0959 & 0.0762 & 83 \\
\hline 29 & 06714000 & 5.302 & 0.6 & 3.2 & -2.0 & 4/14/1993 & $7 / 19 / 2003$ & 146 & 0 & 0.0056 & 0.0130 & 0.6613 & 0.1754 & 57 \\
\hline 35 & 06753990 & 12.187 & -14.7 & -5.3 & -23.2 & 4/13/1993 & $9 / 24 / 2003$ & 76 & 0 & -0.1590 & 0.0524 & 0.0022 & 0.0992 & 96 \\
\hline 36 & 06754000 & 8.027 & 0.7 & 1.5 & -0.1 & 4/7/1993 & $9 / 23 / 2003$ & 132 & 0 & 0.0070 & 0.0039 & 0.0668 & 0.0196 & 97 \\
\hline 37 & 06758500 & -- & -- & -- & -- & -- & -- & -- & -- & -- & -- & -- & -- & -- \\
\hline 39 & 06775900 & 0.825 & -0.5 & 0.9 & -1.9 & $11 / 3 / 1992$ & $9 / 8 / 2003$ & 61 & 0 & -0.0052 & 0.0072 & 0.4482 & 0.0351 & 59 \\
\hline 40 & 06800000 & 4.913 & 2.9 & 5.3 & 0.5 & 4/15/1993 & $9 / 16 / 2003$ & 132 & 0 & 0.0282 & 0.0120 & 0.0176 & 0.1418 & 95 \\
\hline 42 & 06805500 & 3.154 & 4.4 & 6.9 & 2.1 & 11/13/1992 & $9 / 19 / 2003$ & 152 & 0 & 0.0434 & 0.0116 & 0.0002 & 0.1716 & 86 \\
\hline 43 & 06817700 & 4.104 & -0.4 & 3.8 & -4.5 & 11/10/1992 & $7 / 24 / 2003$ & 107 & 0 & -0.0043 & 0.0211 & 0.8358 & 0.2842 & 94 \\
\hline 44 & 06818000 & 3.635 & -5.1 & -2.9 & -7.3 & 11/10/1992 & $9 / 24 / 2003$ & 132 & 0 & -0.0528 & 0.0118 & $<0.0001$ & 0.1455 & 79 \\
\hline 51 & 06902000 & 1.757 & 1.8 & 5.9 & -2.1 & $11 / 12 / 1992$ & $9 / 9 / 2003$ & 125 & 1 & 0.0180 & 0.0197 & 0.3513 & 0.3390 & 94 \\
\hline 52 & 06905500 & 1.968 & -1.2 & 2.7 & -5.0 & $11 / 12 / 1992$ & $9 / 11 / 2003$ & 107 & 1 & -0.0121 & 0.0197 & 0.5308 & 0.3060 & 92 \\
\hline 53 & 06921070 & 0.594 & 3.1 & 7.6 & -1.3 & 11/17/1992 & $9 / 8 / 2003$ & 90 & 1 & 0.0304 & 0.0217 & 0.1524 & 0.3234 & 94 \\
\hline 55 & 06926510 & 0.784 & -0.7 & 2.1 & -3.5 & $11 / 17 / 1992$ & $9 / 3 / 2003$ & 67 & 0 & -0.0070 & 0.0141 & 0.6045 & 0.1049 & 97 \\
\hline 57 & 06930800 & -- & -- & -- & -- & -- & -- & -- & -- & -- & -- & -- & -- & -- \\
\hline 58 & 06934500 & 2.421 & 1.9 & 4.4 & -0.5 & $11 / 24 / 1992$ & 9/9/2003 & 132 & 0 & 0.0188 & 0.0121 & 0.1157 & 0.1041 & 89 \\
\hline \multicolumn{15}{|c|}{ Nitrite plus nitrate } \\
\hline 1 & 06088500 & 1.180 & -6.0 & -2.7 & -9.2 & $10 / 20 / 1992$ & $9 / 10 / 2003$ & 96 & 1 & -0.0620 & 0.0172 & 0.0003 & 0.2794 & 55 \\
\hline 2 & 06089000 & 0.650 & -1.3 & 3.1 & -5.5 & $10 / 20 / 1992$ & $9 / 10 / 2003$ & 85 & 0 & -0.0129 & 0.0220 & 0.5443 & 0.2935 & 40 \\
\hline 5 & 06154410 & -- & -- & -- & -- & -- & -- & -- & -- & -- & -- & -- & -- & -- \\
\hline 6 & 06178000 & -- & -- & -- & -- & -- & -- & -- & -- & -- & -- & -- & -- & -- \\
\hline
\end{tabular}


Appendix 4. Model output for flow-adjusted trends in concentration from 1993 to 2003.-Continued

[CI, confidence interval; --, poor model fit; $\mathrm{R}^{2}$, coefficient of determination between observed and predicted concentrations; significant trend if p-value less than 0.05]

\begin{tabular}{|c|c|c|c|c|c|c|c|c|c|c|c|c|c|c|}
\hline \multirow[b]{2}{*}{$\begin{array}{c}\text { Site } \\
\text { num- } \\
\text { ber } \\
\text { (fig. 1) }\end{array}$} & \multirow[b]{2}{*}{$\begin{array}{c}\text { U.S. } \\
\text { Geologi- } \\
\text { cal Survey } \\
\text { station } \\
\text { number }\end{array}$} & \multirow[b]{2}{*}{$\begin{array}{l}\text { Refer- } \\
\text { ence } \\
\text { concen- } \\
\text { tration, } \\
\text { in } \\
\text { milli- } \\
\text { grams } \\
\text { per liter }\end{array}$} & \multicolumn{3}{|c|}{$\begin{array}{l}\text { Trend, in percent } \\
\text { per year }\end{array}$} & \multicolumn{4}{|c|}{$\begin{array}{l}\text { Properties of the calibration } \\
\text { data set }\end{array}$} & \multicolumn{3}{|c|}{$\begin{array}{l}\text { Properties of the modeled } \\
\text { time term }\end{array}$} & \multicolumn{2}{|c|}{$\begin{array}{l}\text { Properties of } \\
\text { the fitted model }\end{array}$} \\
\hline & & & $\begin{array}{l}\text { Modeled } \\
\text { estimate }\end{array}$ & $\begin{array}{l}\text { Upper } \\
\text { 95- } \\
\text { percent } \\
\text { CI }\end{array}$ & $\begin{array}{l}\text { Lower } \\
\text { 95- } \\
\text { percent } \\
\text { Cl }\end{array}$ & $\begin{array}{l}\text { Start } \\
\text { date }\end{array}$ & $\begin{array}{l}\text { End } \\
\text { date }\end{array}$ & $\begin{array}{c}\text { Num- } \\
\text { ber } \\
\text { of } \\
\text { observ- } \\
\text { ations }\end{array}$ & $\begin{array}{l}\text { Num- } \\
\text { ber of } \\
\text { cens- } \\
\text { ored } \\
\text { observ- } \\
\text { ations }\end{array}$ & $\begin{array}{l}\text { Coeff- } \\
\text { icient }\end{array}$ & $\begin{array}{l}\text { Standard } \\
\text { deviation }\end{array}$ & $\begin{array}{c}p \text { - } \\
\text { value }\end{array}$ & $\begin{array}{l}\text { Residual } \\
\text { variance }\end{array}$ & $\mathbf{R}^{2}$ \\
\hline 11 & 06274300 & 0.385 & -5.9 & -1.9 & -9.8 & $12 / 17 / 1992$ & $8 / 5 / 2003$ & 44 & 0 & -0.0610 & 0.0208 & 0.0028 & 0.1584 & 68 \\
\hline 17 & 06329500 & 0.029 & -1.1 & 7.4 & -8.9 & 10/8/1992 & $9 / 9 / 2003$ & 113 & 25 & -0.0109 & 0.0414 & 0.8006 & 1.073 & 70 \\
\hline 18 & 06338490 & 0.072 & -11.4 & -7.1 & -15.5 & 10/6/1992 & $8 / 28 / 2003$ & 62 & 0 & -0.1209 & 0.0236 & $<0.0001$ & 0.311 & 56 \\
\hline 19 & 06341410 & -- & -- & -- & -- & -- & -- & -- & -- & -- & -- & -- & -- & -- \\
\hline 20 & 06341800 & -- & -- & -- & -- & -- & -- & -- & -- & -- & -- & -- & -- & -- \\
\hline 24 & 06461500 & 0.141 & 3.6 & 7.9 & -0.5 & 10/7/1992 & $9 / 9 / 2003$ & 68 & 3 & 0.0354 & 0.0201 & 0.0717 & 0.2942 & 64 \\
\hline 25 & 06463500 & -- & -- & -- & -- & -- & -- & -- & -- & -- & -- & -- & -- & -- \\
\hline 26 & 06468250 & 0.034 & -12.9 & -3.2 & -21.6 & $11 / 23 / 1992$ & $8 / 25 / 2003$ & 86 & 43 & -0.1379 & 0.0532 & 0.0085 & 1.794 & 83 \\
\hline 28 & 06713500 & 3.290 & -11.6 & -4.5 & -18.1 & $4 / 12 / 1993$ & $9 / 22 / 2003$ & 96 & 0 & -0.1227 & 0.0384 & 0.0013 & 0.0629 & 70 \\
\hline 29 & 06714000 & 3.679 & -1.1 & 1.1 & -3.3 & $4 / 14 / 1993$ & $7 / 19 / 2003$ & 146 & 0 & -0.0114 & 0.0111 & 0.2969 & 0.1284 & 34 \\
\hline 33 & 06752260 & 0.244 & -12.0 & -8.0 & -15.8 & $10 / 28 / 1992$ & $9 / 17 / 2003$ & 130 & 1 & -0.1275 & 0.0225 & $<0.0001$ & 0.6586 & 60 \\
\hline 34 & 06752280 & 0.627 & -1.5 & 2.7 & -5.5 & $10 / 30 / 1992$ & $9 / 17 / 2003$ & 128 & 1 & -0.0151 & 0.0211 & 0.4759 & 0.568 & 68 \\
\hline 35 & 06753990 & 7.886 & -17.6 & -6.9 & -27.1 & 4/13/1993 & $9 / 24 / 2003$ & 76 & 0 & -0.1934 & 0.0613 & 0.0014 & 0.1339 & 94 \\
\hline 36 & 06754000 & 6.163 & 0.3 & 1.0 & -0.5 & 4/7/1993 & $9 / 23 / 2003$ & 132 & 0 & 0.0025 & 0.0040 & 0.5222 & 0.0208 & 97 \\
\hline 37 & 06758500 & -- & -- & -- & -- & -- & -- & -- & -- & -- & -- & -- & -- & -- \\
\hline 39 & 06775900 & 0.555 & 0.7 & 2.1 & -0.7 & 11/3/1992 & $9 / 8 / 2003$ & 61 & 0 & 0.0069 & 0.0070 & 0.3076 & 0.034 & 51 \\
\hline 40 & 06800000 & 3.511 & -3.5 & 0.0 & -7.0 & $4 / 15 / 1993$ & $9 / 16 / 2003$ & 132 & 1 & -0.0360 & 0.0183 & 0.0454 & 0.3239 & 90 \\
\hline 42 & 06805500 & 3.188 & 0.9 & 7.4 & -5.2 & $11 / 13 / 1992$ & $9 / 19 / 2003$ & 152 & 17 & 0.0094 & 0.0316 & 0.7557 & 1.19 & 73 \\
\hline 43 & 06817700 & 3.779 & 3.4 & 15.3 & -7.3 & 11/10/1992 & $7 / 24 / 2003$ & 108 & 17 & 0.0335 & 0.0551 & 0.5330 & 1.949 & 81 \\
\hline 44 & 06818000 & 2.963 & -8.8 & -4.2 & -13.2 & 11/10/1992 & $9 / 24 / 2003$ & 132 & 4 & -0.0919 & 0.0248 & 0.0002 & 0.6469 & 53 \\
\hline 51 & 06902000 & 0.254 & 4.0 & 13.2 & -4.4 & $11 / 12 / 1992$ & 9/9/2003 & 126 & 34 & 0.0394 & 0.0425 & 0.3491 & 1.429 & 86 \\
\hline 52 & 06905500 & 0.780 & 5.7 & 14.7 & -2.5 & $11 / 12 / 1992$ & $9 / 11 / 2003$ & 107 & 21 & 0.0558 & 0.0408 & 0.1673 & 1.239 & 85 \\
\hline 53 & 06921070 & 0.534 & 7.3 & 17.7 & -2.2 & $11 / 17 / 1992$ & $9 / 8 / 2003$ & 90 & 14 & 0.0700 & 0.0466 & 0.1241 & 1.42 & 85 \\
\hline 55 & 06926510 & 0.315 & -8.6 & -2.1 & -14.7 & 11/17/1992 & $9 / 3 / 2003$ & 67 & 9 & -0.0900 & 0.0344 & 0.0082 & 0.6201 & 89 \\
\hline 57 & 06930800 & 0.245 & -0.1 & 4.1 & -4.2 & 11/17/1992 & $9 / 5 / 2003$ & 121 & 2 & -0.0011 & 0.0209 & 0.9563 & 0.3755 & 87 \\
\hline 58 & 06934500 & 1.690 & -2.8 & 1.6 & -7.1 & 11/24/1992 & $9 / 9 / 2003$ & 133 & 2 & -0.0288 & 0.0225 & 0.1942 & 0.3606 & 72 \\
\hline
\end{tabular}


Appendix 4. Model output for flow-adjusted trends in concentration from 1993 to 2003._- Continued

[CI, confidence interval; --, poor model fit; $\mathrm{R}^{2}$, coefficient of determination between observed and predicted concentrations; significant trend if p-value less than 0.05]

\begin{tabular}{|c|c|c|c|c|c|c|c|c|c|c|c|c|c|c|}
\hline \multirow[b]{2}{*}{$\begin{array}{c}\text { Site } \\
\text { num- } \\
\text { ber } \\
\text { (fig. 1) }\end{array}$} & \multirow[b]{2}{*}{$\begin{array}{c}\text { U.S. } \\
\text { Geologi- } \\
\text { cal Survey } \\
\text { station } \\
\text { number }\end{array}$} & \multirow[b]{2}{*}{$\begin{array}{c}\text { Refeence } \\
\text { concen- } \\
\text { tration, } \\
\text { in } \\
\text { milli- } \\
\text { grams } \\
\text { per liter }\end{array}$} & \multicolumn{3}{|c|}{$\begin{array}{c}\text { Trend, in percent } \\
\text { per year }\end{array}$} & \multicolumn{4}{|c|}{$\begin{array}{c}\text { Properties of the calibration } \\
\text { data set }\end{array}$} & \multicolumn{3}{|c|}{$\begin{array}{c}\text { Properties of the modeled } \\
\text { time term }\end{array}$} & \multicolumn{2}{|c|}{$\begin{array}{l}\text { Properties of } \\
\text { the fitted model }\end{array}$} \\
\hline & & & $\begin{array}{l}\text { Modeled } \\
\text { estimate }\end{array}$ & $\begin{array}{l}\text { Upper } \\
\text { 95- } \\
\text { percent } \\
\text { CI }\end{array}$ & $\begin{array}{l}\text { Lower } \\
\text { 95- } \\
\text { percent } \\
\text { Cl }\end{array}$ & $\begin{array}{l}\text { Start } \\
\text { date }\end{array}$ & $\begin{array}{l}\text { End } \\
\text { date }\end{array}$ & $\begin{array}{c}\text { Num- } \\
\text { ber } \\
\text { of } \\
\text { observ- } \\
\text { ations }\end{array}$ & $\begin{array}{c}\text { Num- } \\
\text { ber of } \\
\text { cens- } \\
\text { ored } \\
\text { observ- } \\
\text { ations }\end{array}$ & $\begin{array}{l}\text { Coeff- } \\
\text { icient }\end{array}$ & $\begin{array}{l}\text { Standard } \\
\text { deviation }\end{array}$ & $\begin{array}{c}p- \\
\text { value }\end{array}$ & $\begin{array}{l}\text { Residual } \\
\text { variance }\end{array}$ & $\mathbf{R}^{2}$ \\
\hline \multicolumn{15}{|c|}{ Ammonia } \\
\hline 1 & 06088500 & 0.013 & -13.1 & -8.0 & -18.0 & $10 / 20 / 1992$ & $9 / 10 / 2003$ & 96 & 41 & -0.1408 & 0.0291 & $<0.0001$ & 0.522 & 69 \\
\hline 2 & 06089000 & 0.030 & -9.1 & -4.0 & -13.9 & $10 / 20 / 1992$ & $9 / 10 / 2003$ & 84 & 35 & -0.0949 & 0.0274 & 0.0002 & 0.4037 & 65 \\
\hline 5 & 06154410 & -- & -- & -- & -- & -- & -- & -- & -- & -- & -- & -- & -- & -- \\
\hline 11 & 06274300 & 0.030 & -5.2 & 3.4 & -13.1 & $12 / 17 / 1992$ & $8 / 5 / 2003$ & 44 & 20 & -0.0536 & 0.0430 & 0.1787 & 0.5774 & 61 \\
\hline 17 & 06329500 & 0.005 & -15.5 & -6.6 & -23.5 & 10/8/1992 & $9 / 9 / 2003$ & 113 & 49 & -0.1679 & 0.0504 & 0.0003 & 1.14 & 63 \\
\hline 18 & 06338490 & 0.020 & -9.7 & -0.2 & -18.4 & 10/6/1992 & $8 / 28 / 2003$ & 62 & 20 & -0.1025 & 0.0501 & 0.0280 & 1.13 & 16 \\
\hline 19 & 06341410 & 0.380 & -10.6 & -1.4 & -19.0 & $10 / 5 / 1992$ & $5 / 27 / 2003$ & 66 & 18 & -0.1125 & 0.0490 & 0.0159 & 1.311 & 70 \\
\hline 20 & 06341800 & 0.034 & -4.8 & 3.1 & -12.1 & $10 / 5 / 1992$ & $5 / 28 / 2003$ & 66 & 21 & -0.0493 & 0.0401 & 0.2009 & 0.8803 & 77 \\
\hline 24 & 06461500 & -- & -- & -- & -- & -- & -- & -- & -- & -- & -- & -- & -- & -- \\
\hline 25 & 06463500 & 0.029 & -5.3 & -1.0 & -9.4 & 10/8/1992 & $2 / 13 / 2003$ & 65 & 24 & -0.0545 & 0.0221 & 0.0063 & 0.2031 & 46 \\
\hline 26 & 06468250 & 0.039 & -15.5 & -5.1 & -24.9 & $11 / 23 / 1992$ & $8 / 25 / 2003$ & 86 & 33 & -0.1690 & 0.0588 & 0.0029 & 2.293 & 72 \\
\hline 28 & 06713500 & 0.023 & -36.7 & 1.9 & -60.6 & $4 / 12 / 1993$ & $9 / 22 / 2003$ & 97 & 38 & -0.4566 & 0.2394 & 0.0450 & 1.894 & 61 \\
\hline 29 & 06714000 & 0.254 & 6.6 & 17.3 & -3.1 & $4 / 14 / 1993$ & $7 / 19 / 2003$ & 157 & 33 & -0.0047 & 0.0356 & 0.8949 & 1.299 & 30 \\
\hline 33 & 06752260 & -- & -- & -- & -- & -- & -- & -- & -- & -- & -- & -- & -- & -- \\
\hline 34 & 06752280 & 0.065 & -14.1 & -9.8 & -18.3 & $10 / 30 / 1992$ & $9 / 17 / 2003$ & 129 & 29 & -0.1525 & 0.0249 & $<0.0001$ & 0.7324 & 73 \\
\hline 35 & 06753990 & 0.023 & -16.6 & 44.1 & -51.7 & 4/13/1993 & $9 / 24 / 2003$ & 77 & 17 & -0.1812 & 0.2741 & 0.4808 & 2.441 & 75 \\
\hline 36 & 06754000 & 0.445 & 2.2 & 6.8 & -2.3 & 4/7/1993 & $9 / 23 / 2003$ & 131 & 2 & 0.0213 & 0.0223 & 0.3306 & 0.6459 & 63 \\
\hline 37 & 06758500 & 0.031 & -12.4 & -1.2 & -22.4 & $12 / 10 / 1992$ & $9 / 5 / 2003$ & 46 & 12 & -0.1327 & 0.0597 & 0.0153 & 1.4 & 54 \\
\hline 39 & 06775900 & -- & -- & -- & -- & -- & -- & -- & -- & -- & -- & -- & -- & -- \\
\hline 40 & 06800000 & 0.026 & -6.5 & 2.4 & -14.6 & 4/15/1993 & 9/16/2003 & 132 & 50 & -0.0672 & 0.0458 & 0.1368 & 1.801 & 78 \\
\hline 42 & 06805500 & 0.169 & 2.4 & 9.8 & -4.5 & $11 / 13 / 1992$ & $9 / 19 / 2003$ & 152 & 53 & 0.0238 & 0.0353 & 0.4868 & 1.365 & 64 \\
\hline 43 & 06817700 & 0.111 & -10.4 & -1.5 & -18.5 & $11 / 10 / 1992$ & $7 / 24 / 2003$ & 108 & 31 & -0.1095 & 0.0477 & 0.0127 & 1.184 & 75 \\
\hline 44 & 06818000 & 0.133 & -12.0 & -6.9 & -16.7 & $11 / 10 / 1992$ & $9 / 24 / 2003$ & 132 & 35 & -0.1276 & 0.0281 & $<0.0001$ & 0.7387 & 56 \\
\hline 51 & 06902000 & 0.027 & -7.3 & 0.4 & -14.4 & $11 / 12 / 1992$ & $9 / 9 / 2003$ & 126 & 54 & -0.0760 & 0.0403 & 0.0521 & 1.202 & 81 \\
\hline 52 & 06905500 & 0.064 & -10.4 & -3.4 & -16.8 & $11 / 12 / 1992$ & $9 / 11 / 2003$ & 107 & 29 & -0.1093 & 0.0379 & 0.0027 & 0.9648 & 78 \\
\hline 53 & 06921070 & 0.017 & -7.7 & -2.2 & -12.9 & $11 / 17 / 1992$ & $9 / 8 / 2003$ & 90 & 38 & -0.0802 & 0.0290 & 0.0034 & 0.4131 & 90 \\
\hline 55 & 06926510 & -- & -- & -- & -- & -- & -- & -- & -- & -- & -- & -- & -- & -- \\
\hline
\end{tabular}


Appendix 4. Model output for flow-adjusted trends in concentration from 1993 to 2003.—Continued

[CI, confidence interval; --, poor model fit; $\mathrm{R}^{2}$, coefficient of determination between observed and predicted concentrations; significant trend if $\mathrm{p}$-value less than 0.05 ]

\begin{tabular}{|c|c|c|c|c|c|c|c|c|c|c|c|c|c|c|}
\hline \multirow[b]{2}{*}{$\begin{array}{c}\text { Site } \\
\text { num- } \\
\text { ber } \\
\text { (fig. 1) }\end{array}$} & \multirow[b]{2}{*}{$\begin{array}{c}\text { U.S. } \\
\text { Geologi- } \\
\text { cal Survey } \\
\text { station } \\
\text { number }\end{array}$} & \multirow[b]{2}{*}{$\begin{array}{c}\text { Refeence } \\
\text { concen- } \\
\text { tration, } \\
\text { in } \\
\text { milli- } \\
\text { grams } \\
\text { per liter }\end{array}$} & \multicolumn{3}{|c|}{$\begin{array}{l}\text { Trend, in percent } \\
\text { per year }\end{array}$} & \multicolumn{4}{|c|}{$\begin{array}{c}\text { Properties of the calibration } \\
\text { data set }\end{array}$} & \multicolumn{3}{|c|}{$\begin{array}{c}\text { Properties of the modeled } \\
\text { time term }\end{array}$} & \multicolumn{2}{|c|}{$\begin{array}{l}\text { Properties of } \\
\text { the fitted model }\end{array}$} \\
\hline & & & $\begin{array}{l}\text { Modeled } \\
\text { estimate }\end{array}$ & $\begin{array}{l}\text { Upper } \\
\text { 95- } \\
\text { percent } \\
\text { CI } \\
\end{array}$ & $\begin{array}{l}\text { Lower } \\
\text { 95- } \\
\text { percent } \\
\text { CI } \\
\end{array}$ & $\begin{array}{l}\text { Start } \\
\text { date }\end{array}$ & $\begin{array}{l}\text { End } \\
\text { date }\end{array}$ & $\begin{array}{c}\text { Num- } \\
\text { ber } \\
\text { of } \\
\text { observ- } \\
\text { ations }\end{array}$ & $\begin{array}{c}\text { Num- } \\
\text { ber of } \\
\text { cens- } \\
\text { ored } \\
\text { observ- } \\
\text { ations }\end{array}$ & $\begin{array}{l}\text { Coeff- } \\
\text { icient }\end{array}$ & $\begin{array}{l}\text { Standard } \\
\text { deviation }\end{array}$ & $\begin{array}{c}p \text { - } \\
\text { value }\end{array}$ & $\begin{array}{l}\text { Residual } \\
\text { variance }\end{array}$ & $\mathbf{R}^{2}$ \\
\hline 57 & 06930800 & -- & -- & -- & -- & -- & -- & -- & -- & -- & -- & -- & -- & -- \\
\hline 58 & 06934500 & 0.063 & -14.8 & -8.2 & -21.0 & $11 / 24 / 1992$ & 9/9/2003 & 133 & 67 & -0.1606 & 0.0381 & $<0.0001$ & 0.7179 & 63 \\
\hline \multicolumn{15}{|c|}{ Total phosphorus } \\
\hline 2 & 06089000 & 0.047 & 1.6 & 7.9 & -4.4 & 10/20/1992 & $9 / 10 / 2003$ & 84 & 29 & 0.0155 & 0.0303 & 0.5289 & 0.4231 & 82 \\
\hline 6 & 06178000 & 0.040 & -1.3 & 5.1 & -7.3 & 10/15/1992 & $8 / 13 / 2003$ & 53 & 21 & -0.0129 & 0.0312 & 0.6173 & 0.3137 & 96 \\
\hline 17 & 06329500 & 0.184 & 5.1 & 12.9 & -2.2 & 10/8/1992 & 9/9/2003 & 113 & 9 & 0.0497 & 0.0364 & 0.1430 & 0.8261 & 76 \\
\hline 18 & 06338490 & -- & -- & -- & -- & -- & -- & -- & -- & -- & -- & -- & -- & -- \\
\hline 24 & 06461500 & 0.169 & 3.0 & 5.9 & 0.3 & 10/7/1992 & 9/9/2003 & 70 & 0 & 0.0300 & 0.0136 & 0.0235 & 0.1401 & 60 \\
\hline 25 & 06463500 & 0.203 & 2.1 & 5.1 & -0.9 & $10 / 8 / 1992$ & $2 / 13 / 2003$ & 65 & 0 & 0.0205 & 0.0148 & 0.1587 & 0.1277 & 71 \\
\hline 28 & 06713500 & -- & -- & -- & -- & -- & -- & -- & -- & -- & -- & -- & -- & -- \\
\hline 29 & 06714000 & 0.841 & 0.5 & 4.1 & -3.0 & 4/14/1993 & $7 / 19 / 2003$ & 157 & 0 & 0.0045 & 0.0178 & 0.7950 & 0.3497 & 49 \\
\hline 35 & 06753990 & 0.105 & -6.2 & 25.7 & -30.1 & 4/13/1993 & $9 / 24 / 2003$ & 77 & 0 & -0.0645 & 0.1470 & 0.6456 & 0.7972 & 88 \\
\hline 36 & 06754000 & 0.967 & 2.3 & 3.9 & 0.7 & 4/7/1993 & $9 / 23 / 2003$ & 131 & 0 & 0.0226 & 0.0079 & 0.0042 & 0.0829 & 92 \\
\hline 37 & 06758500 & 0.414 & 0.6 & 5.2 & -3.9 & $12 / 10 / 1992$ & $9 / 5 / 2003$ & 46 & 0 & 0.0056 & 0.0224 & 0.7921 & 0.2325 & 88 \\
\hline 39 & 06775900 & -- & -- & -- & -- & -- & -- & -- & -- & -- & -- & -- & -- & -- \\
\hline 40 & 06800000 & 0.455 & 13.9 & 18.3 & 9.7 & $4 / 15 / 1993$ & $9 / 16 / 2003$ & 129 & 0 & 0.1306 & 0.0190 & $<0.0001$ & 0.3692 & 90 \\
\hline 42 & 06805500 & 0.395 & 10.3 & 13.5 & 7.1 & 11/13/1992 & $9 / 19 / 2003$ & 150 & 0 & 0.0976 & 0.0148 & $<0.0001$ & 0.2678 & 82 \\
\hline 43 & 06817700 & 0.239 & 6.1 & 11.6 & 0.8 & 11/10/1992 & $7 / 24 / 2003$ & 94 & 2 & 0.0589 & 0.0258 & 0.0205 & 0.4114 & 92 \\
\hline 44 & 06818000 & 0.200 & 4.9 & 8.7 & 1.2 & 11/10/1992 & $9 / 24 / 2003$ & 119 & 0 & 0.0479 & 0.0180 & 0.0074 & 0.3329 & 67 \\
\hline 51 & 06902000 & 0.193 & 9.7 & 14.4 & 5.3 & 11/12/1992 & $9 / 9 / 2003$ & 111 & 1 & 0.0930 & 0.0209 & $<0.0001$ & 0.3396 & 94 \\
\hline 52 & 06905500 & 0.175 & 2.6 & 7.8 & -2.3 & 11/12/1992 & $9 / 11 / 2003$ & 94 & 6 & 0.0256 & 0.0249 & 0.2864 & 0.4523 & 92 \\
\hline 53 & 06921070 & 0.090 & 0.9 & 4.6 & -2.7 & 11/17/1992 & $9 / 8 / 2003$ & 84 & 23 & 0.0087 & 0.0180 & 0.6109 & 0.1795 & 96 \\
\hline 55 & 06926510 & -- & -- & -- & -- & -- & -- & -- & -- & -- & -- & -- & -- & -- \\
\hline 57 & 06930800 & -- & -- & -- & -- & -- & -- & -- & -- & -- & -- & -- & -- & -- \\
\hline 58 & 06934500 & 0.317 & 12.1 & 16.9 & 7.4 & $11 / 24 / 1992$ & 9/9/2003 & 131 & 1 & 0.1138 & 0.0213 & $<0.0001$ & 0.3854 & 71 \\
\hline \multicolumn{15}{|c|}{ Orthophosphorus } \\
\hline 1 & 06088500 & -- & -- & -- & -- & -- & -- & -- & -- & -- & -- & -- & -- & -- \\
\hline 2 & 06089000 & -- & -- & -- & -- & -- & -- & -- & -- & -- & -- & -- & -- & -- \\
\hline 5 & 06154410 & -- & -- & -- & -- & -- & -- & -- & -- & -- & -- & -- & -- & -- \\
\hline 6 & 06178000 & 0.010 & -8.0 & -1.4 & -14.1 & 10/15/1992 & $8 / 13 / 2003$ & 53 & 22 & -0.0829 & 0.0344 & 0.0136 & 0.4196 & 95 \\
\hline
\end{tabular}


Appendix 4. Model output for flow-adjusted trends in concentration from 1993 to 2003.-Continued

[CI, confidence interval; --, poor model fit; $\mathrm{R}^{2}$, coefficient of determination between observed and predicted concentrations; significant trend if p-value less than 0.05]

\begin{tabular}{|c|c|c|c|c|c|c|c|c|c|c|c|c|c|c|}
\hline \multirow[b]{2}{*}{$\begin{array}{c}\text { Site } \\
\text { num- } \\
\text { ber } \\
\text { (fig. 1) }\end{array}$} & \multirow[b]{2}{*}{$\begin{array}{c}\text { U.S. } \\
\text { Geologi- } \\
\text { cal Survey } \\
\text { station } \\
\text { number }\end{array}$} & \multirow[b]{2}{*}{$\begin{array}{c}\text { Refeence } \\
\text { concen- } \\
\text { tration, } \\
\text { in } \\
\text { milli- } \\
\text { grams } \\
\text { per liter }\end{array}$} & \multicolumn{3}{|c|}{$\begin{array}{c}\text { Trend, in percent } \\
\text { per year }\end{array}$} & \multicolumn{4}{|c|}{$\begin{array}{c}\text { Properties of the calibration } \\
\text { data set }\end{array}$} & \multicolumn{3}{|c|}{$\begin{array}{c}\text { Properties of the modeled } \\
\text { time term }\end{array}$} & \multicolumn{2}{|c|}{$\begin{array}{l}\text { Properties of } \\
\text { the fitted model }\end{array}$} \\
\hline & & & $\begin{array}{l}\text { Modeled } \\
\text { estimate }\end{array}$ & $\begin{array}{l}\text { Upper } \\
\text { 95- } \\
\text { percent } \\
\text { CI }\end{array}$ & $\begin{array}{l}\text { Lower } \\
\text { 95- } \\
\text { percent } \\
\text { Cl }\end{array}$ & $\begin{array}{l}\text { Start } \\
\text { date }\end{array}$ & $\begin{array}{l}\text { End } \\
\text { date }\end{array}$ & $\begin{array}{l}\text { Num- } \\
\text { ber } \\
\text { of } \\
\text { observ- } \\
\text { ations }\end{array}$ & $\begin{array}{l}\text { Num- } \\
\text { ber of } \\
\text { cens- } \\
\text { ored } \\
\text { observ- } \\
\text { ations }\end{array}$ & $\begin{array}{l}\text { Coeff- } \\
\text { icient }\end{array}$ & $\begin{array}{l}\text { Standard } \\
\text { deviation }\end{array}$ & $\begin{array}{c}p- \\
\text { value }\end{array}$ & $\begin{array}{l}\text { Residual } \\
\text { variance }\end{array}$ & $\mathbf{R}^{2}$ \\
\hline 11 & 06274300 & 0.014 & -7.9 & -0.8 & -14.5 & $12 / 17 / 1992$ & $8 / 5 / 2003$ & 44 & 22 & -0.0824 & 0.0369 & 0.0135 & 0.3545 & 80 \\
\hline 17 & 06329500 & 0.004 & -4.7 & 8.3 & -16.2 & $10 / 8 / 1992$ & 9/9/2003 & 113 & 57 & -0.0486 & 0.0648 & 0.4004 & 1.288 & 70 \\
\hline 18 & 06338490 & -- & -- & -- & -- & -- & -- & -- & -- & -- & -- & -- & -- & -- \\
\hline 19 & 06341410 & 0.088 & -9.7 & -3.5 & -15.6 & $10 / 5 / 1992$ & $5 / 27 / 2003$ & 66 & 3 & -0.1026 & 0.0333 & 0.0021 & 0.6984 & 80 \\
\hline 20 & 06341800 & 0.017 & 2.6 & 12.4 & -6.4 & $10 / 5 / 1992$ & $5 / 28 / 2003$ & 66 & 16 & 0.0254 & 0.0459 & 0.5591 & 1.241 & 77 \\
\hline 24 & 06461500 & 0.045 & 1.7 & 5.4 & -1.9 & 10/7/1992 & 9/9/2003 & 69 & 2 & 0.0166 & 0.0179 & 0.3389 & 0.2454 & 48 \\
\hline 25 & 06463500 & -- & -- & -- & -- & -- & -- & -- & -- & -- & -- & -- & -- & -- \\
\hline 26 & 06468250 & 0.140 & -12.4 & -5.1 & -19.1 & $11 / 23 / 1992$ & $8 / 25 / 2003$ & 86 & 9 & -0.1323 & 0.0403 & 0.0010 & 1.229 & 88 \\
\hline 28 & 06713500 & 0.243 & -13.2 & -5.6 & -20.1 & $4 / 12 / 1993$ & $9 / 22 / 2003$ & 96 & 0 & -0.1414 & 0.0419 & 0.0007 & 0.0749 & 85 \\
\hline 29 & 06714000 & 0.539 & -2.3 & 0.3 & -4.8 & $4 / 14 / 1993$ & $7 / 19 / 2003$ & 156 & 1 & -0.0228 & 0.0133 & 0.0829 & 0.1935 & 22 \\
\hline 33 & 06752260 & -- & -- & -- & -- & -- & -- & -- & -- & -- & -- & -- & -- & -- \\
\hline 34 & 06752280 & 0.034 & 8.1 & 15.5 & 1.2 & $10 / 30 / 1992$ & $9 / 17 / 2003$ & 130 & 39 & 0.0778 & 0.0334 & 0.0187 & 1.293 & 75 \\
\hline 35 & 06753990 & 0.005 & -2.2 & 50.5 & -36.4 & 4/13/1993 & $9 / 24 / 2003$ & 77 & 15 & -0.0220 & 0.2161 & 0.9096 & 1.564 & 80 \\
\hline 36 & 06754000 & 0.757 & 1.9 & 3.7 & 0.2 & 4/7/1993 & $9 / 23 / 2003$ & 132 & 0 & 0.0188 & 0.0087 & 0.0293 & 0.101 & 89 \\
\hline 37 & 06758500 & -- & -- & -- & -- & -- & -- & -- & -- & -- & -- & -- & -- & -- \\
\hline 39 & 06775900 & -- & -- & -- & -- & -- & -- & -- & -- & -- & -- & -- & -- & -- \\
\hline 40 & 06800000 & 0.185 & 6.7 & 10.3 & 3.2 & 4/15/1993 & $9 / 16 / 2003$ & 132 & 1 & 0.0648 & 0.0167 & 0.0001 & 0.2714 & 89 \\
\hline 42 & 06805500 & -- & -- & -- & -- & -- & -- & -- & -- & -- & -- & -- & -- & -- \\
\hline 43 & 06817700 & 0.102 & -9.1 & -4.1 & -13.8 & $11 / 10 / 1992$ & $7 / 24 / 2003$ & 108 & 3 & -0.0949 & 0.0270 & 0.0005 & 0.572 & 85 \\
\hline 44 & 06818000 & 0.109 & -8.6 & -5.7 & -11.5 & $11 / 10 / 1992$ & $9 / 24 / 2003$ & 130 & 2 & -0.0904 & 0.0158 & $<0.0001$ & 0.2466 & 66 \\
\hline 51 & 06902000 & 0.043 & 1.3 & 6.1 & -3.2 & $11 / 12 / 1992$ & 9/9/2003 & 126 & 27 & 0.0131 & 0.0231 & 0.5645 & 0.4091 & 94 \\
\hline 52 & 06905500 & 0.057 & -17.2 & -12.3 & -21.8 & $11 / 12 / 1992$ & $9 / 11 / 2003$ & 106 & 21 & -0.1886 & 0.0287 & $<0.0001$ & 0.538 & 91 \\
\hline 53 & 06921070 & 0.024 & -2.1 & 3.2 & -7.2 & $11 / 17 / 1992$ & $9 / 8 / 2003$ & 90 & 16 & -0.0215 & 0.0266 & 0.4050 & 0.4528 & 90 \\
\hline 55 & 06926510 & -- & -- & -- & -- & -- & -- & -- & -- & -- & -- & -- & -- & -- \\
\hline 57 & 06930800 & 0.017 & -4.6 & -0.9 & -8.1 & $11 / 17 / 1992$ & $9 / 5 / 2003$ & 121 & 46 & -0.0467 & 0.0191 & 0.0111 & 0.2506 & 89 \\
\hline 58 & 06934500 & 0.074 & -1.2 & 2.2 & -4.4 & $11 / 24 / 1992$ & 9/9/2003 & 133 & 0 & -0.0116 & 0.0168 & 0.4805 & 0.1952 & 69 \\
\hline \multicolumn{15}{|c|}{ Suspended sediment } \\
\hline 1 & 06088500 & 127.683 & -8.2 & -5.0 & -11.3 & $10 / 20 / 1992$ & $9 / 10 / 2003$ & 96 & 0 & -0.0853 & 0.0174 & $<0.0001$ & 0.2854 & 92 \\
\hline
\end{tabular}


Appendix 4. Model output for flow-adjusted trends in concentration from 1993 to 2003.—Continued

[CI, confidence interval; --, poor model fit; $\mathrm{R}^{2}$, coefficient of determination between observed and predicted concentrations; significant trend if p-value less than 0.05]

\begin{tabular}{|c|c|c|c|c|c|c|c|c|c|c|c|c|c|c|}
\hline \multirow[b]{2}{*}{$\begin{array}{l}\text { Site } \\
\text { num- } \\
\text { ber } \\
\text { (fig. 1) }\end{array}$} & \multirow[b]{2}{*}{$\begin{array}{l}\text { U.S. } \\
\text { Geologi- } \\
\text { cal Survey } \\
\text { station } \\
\text { number }\end{array}$} & \multirow[b]{2}{*}{$\begin{array}{c}\text { Refeence } \\
\text { concen- } \\
\text { tration, } \\
\text { in } \\
\text { milli- } \\
\text { grams } \\
\text { per liter }\end{array}$} & \multicolumn{3}{|c|}{$\begin{array}{c}\text { Trend, in percent } \\
\text { per year }\end{array}$} & \multicolumn{4}{|c|}{$\begin{array}{c}\text { Properties of the calibration } \\
\text { data set }\end{array}$} & \multicolumn{3}{|c|}{$\begin{array}{c}\text { Properties of the modeled } \\
\text { time term }\end{array}$} & \multicolumn{2}{|c|}{$\begin{array}{c}\text { Properties of } \\
\text { the fitted model }\end{array}$} \\
\hline & & & $\begin{array}{l}\text { Modeled } \\
\text { estimate }\end{array}$ & $\begin{array}{l}\text { Upper } \\
\text { 95- } \\
\text { percent } \\
\text { Cl }\end{array}$ & $\begin{array}{l}\text { Lower } \\
\text { 95- } \\
\text { percent } \\
\text { Cl }\end{array}$ & $\begin{array}{l}\text { Start } \\
\text { date }\end{array}$ & $\begin{array}{l}\text { End } \\
\text { date }\end{array}$ & $\begin{array}{c}\text { Num- } \\
\text { ber } \\
\text { of } \\
\text { observ- } \\
\text { ations }\end{array}$ & $\begin{array}{l}\text { ber of } \\
\text { cens- } \\
\text { ored } \\
\text { observ- } \\
\text { ations }\end{array}$ & $\begin{array}{l}\text { Coeff- } \\
\text { icient }\end{array}$ & $\begin{array}{l}\text { Standard } \\
\text { deviation }\end{array}$ & $\begin{array}{c}p- \\
\text { value }\end{array}$ & $\begin{array}{l}\text { Residual } \\
\text { variance }\end{array}$ & $\mathbf{R}^{2}$ \\
\hline 2 & 06089000 & 37.691 & -4.0 & 0.1 & -8.0 & $10 / 20 / 1992$ & $9 / 10 / 2003$ & 85 & 0 & -0.0411 & 0.0211 & 0.0462 & 0.2716 & 89 \\
\hline 3 & 06115200 & 318.141 & 16.6 & 27.9 & 6.4 & 11/18/1992 & $7 / 21 / 2003$ & 55 & 0 & 0.1540 & 0.0457 & 0.0010 & 1.187 & 62 \\
\hline 4 & 06130500 & 227.061 & 5.4 & 13.2 & -1.8 & $10 / 6 / 1992$ & $6 / 17 / 2003$ & 74 & 0 & 0.0525 & 0.0356 & 0.1271 & 0.5276 & 97 \\
\hline 5 & 06154410 & 29.298 & 0.2 & 7.1 & -6.3 & $12 / 3 / 1992$ & $6 / 25 / 2003$ & 38 & 0 & 0.0020 & 0.0328 & 0.9480 & 0.2913 & 84 \\
\hline 6 & 06178000 & 34.257 & -0.2 & 9.0 & -8.7 & $10 / 15 / 1992$ & $8 / 13 / 2003$ & 51 & 0 & -0.0024 & 0.0439 & 0.9544 & 0.8737 & 88 \\
\hline 17 & 06329500 & 95.284 & -4.2 & 1.1 & -9.1 & 10/8/1992 & $9 / 9 / 2003$ & 137 & 0 & -0.0426 & 0.0269 & 0.1083 & 0.7123 & 84 \\
\hline 21 & 06436180 & 22.597 & -6.2 & 0.3 & -12.2 & $10 / 13 / 1992$ & $9 / 8 / 2003$ & 59 & 0 & -0.0636 & 0.0334 & 0.0478 & 0.7166 & 90 \\
\hline 22 & 06441500 & 630.768 & -5.5 & 4.0 & -14.2 & 2/4/1993 & $7 / 2 / 2003$ & 80 & 0 & -0.0571 & 0.0482 & 0.2245 & 1.565 & 95 \\
\hline 23 & 06452000 & 509.729 & 0.5 & 8.1 & -6.5 & 10/8/1992 & $9 / 10 / 2003$ & 103 & 0 & 0.0052 & 0.0364 & 0.8828 & 1.281 & 88 \\
\hline 26 & 06468250 & 37.495 & 14.9 & 22.7 & 7.6 & $11 / 23 / 1992$ & $8 / 25 / 2003$ & 83 & 0 & 0.1388 & 0.0330 & $<0.0001$ & 0.8144 & 84 \\
\hline 28 & 06713500 & 0.204 & 22.1 & 80.6 & -17.4 & $4 / 12 / 1993$ & $9 / 22 / 2003$ & 90 & 0 & 0.1999 & 0.1968 & 0.2986 & 1.574 & 76 \\
\hline 35 & 06753990 & 2.536 & 13.1 & 57.9 & -18.9 & 4/13/1993 & $9 / 24 / 2003$ & 74 & 0 & 0.1233 & 0.1670 & 0.4421 & 1.008 & 87 \\
\hline 36 & 06754000 & 124.159 & -4.4 & -0.4 & -8.3 & 4/7/1993 & $9 / 23 / 2003$ & 130 & 0 & -0.0455 & 0.0210 & 0.0281 & 0.5429 & 86 \\
\hline 39 & 06775900 & 872.600 & -21.2 & -10.9 & -30.4 & $11 / 3 / 1992$ & $9 / 8 / 2003$ & 51 & 0 & -0.2386 & 0.0610 & 0.0001 & 0.1393 & 62 \\
\hline 40 & 06800000 & 290.632 & -6.2 & -0.6 & -11.5 & $4 / 15 / 1993$ & $9 / 16 / 2003$ & 129 & 0 & -0.0640 & 0.0294 & 0.0284 & 0.9246 & 90 \\
\hline 42 & 06805500 & 638.672 & 4.2 & 9.2 & -0.6 & $11 / 13 / 1992$ & 9/19/2003 & 146 & 0 & 0.0410 & 0.0238 & 0.0817 & 0.6797 & 81 \\
\hline 58 & 06934500 & 519.821 & -1.3 & 3.3 & -5.7 & $5 / 13 / 1993$ & $7 / 8 / 2003$ & 125 & 0 & -0.0133 & 0.0232 & 0.5558 & 0.3428 & 86 \\
\hline
\end{tabular}


Appendix 5. Model output for non-flow-adjusted trends in concentration from 1993 to 2003

[CI, confidence interval; --, poor model fit; significant trend if p-value less than 0.05]

\begin{tabular}{|c|c|c|c|c|c|c|c|c|c|c|c|c|c|}
\hline \multirow[b]{2}{*}{$\begin{array}{c}\text { Site } \\
\text { num- } \\
\text { ber } \\
\text { (fig. 1) }\end{array}$} & \multirow[b]{2}{*}{$\begin{array}{c}\text { U.S. } \\
\text { Geologcal } \\
\text { Survey } \\
\text { station } \\
\text { number }\end{array}$} & \multirow[b]{2}{*}{$\begin{array}{c}\text { Reference } \\
\text { concentra- } \\
\text { tion, } \\
\text { in } \\
\text { milligrams } \\
\text { per liter }\end{array}$} & \multicolumn{3}{|c|}{$\begin{array}{l}\text { Trend, in percent } \\
\text { per year }\end{array}$} & \multicolumn{4}{|c|}{$\begin{array}{l}\text { Properties of the calibration } \\
\text { data set }\end{array}$} & \multicolumn{3}{|c|}{$\begin{array}{l}\text { Properties of the modeled } \\
\text { trend term }\end{array}$} & \multirow[b]{2}{*}{$\begin{array}{c}\text { Root } \\
\text { mean } \\
\text { squared } \\
\text { error of } \\
\text { the fitted } \\
\text { model }\end{array}$} \\
\hline & & & $\begin{array}{l}\text { Modeled } \\
\text { estimate }\end{array}$ & $\begin{array}{c}\text { Upper } \\
\text { 95-percent } \\
\text { Cl }\end{array}$ & $\begin{array}{l}\text { Lower } \\
\text { 95-per- } \\
\text { cent Cl }\end{array}$ & $\begin{array}{l}\text { Start } \\
\text { date }\end{array}$ & $\begin{array}{l}\text { End } \\
\text { date }\end{array}$ & $\begin{array}{c}\text { Number } \\
\text { of } \\
\text { obser- } \\
\text { vations }\end{array}$ & $\begin{array}{l}\text { Number } \\
\text { of } \\
\text { censored } \\
\text { observ- } \\
\text { ations }\end{array}$ & $\begin{array}{l}\text { Coeff- } \\
\text { icient }\end{array}$ & $\begin{array}{l}\text { Standard } \\
\text { deviation }\end{array}$ & $\begin{array}{c}p- \\
\text { value }\end{array}$ & \\
\hline \multicolumn{14}{|c|}{ Total nitrogen } \\
\hline 6 & 06178000 & 0.660 & 0.8 & 4.6 & -2.0 & $10 / 15 / 1992$ & $8 / 13 / 2003$ & 53 & 0 & 0.0796 & 0.1669 & 0.6335 & 0.273 \\
\hline 17 & 06329500 & 0.567 & 2.2 & 6.8 & -1.1 & 10/8/1992 & 9/9/2003 & 113 & 1 & 0.2169 & 0.1734 & 0.2111 & 0.473 \\
\hline 18 & 06338490 & 0.283 & 3.6 & 12.1 & -1.4 & 10/6/1992 & $8 / 28 / 2003$ & 61 & 0 & 0.3337 & 0.2576 & 0.1953 & 0.566 \\
\hline 24 & 06461500 & 0.427 & 5.3 & 11.5 & 0.9 & $10 / 7 / 1992$ & 9/9/2003 & 68 & 0 & 0.4565 & 0.1831 & 0.0127 & 0.445 \\
\hline 25 & 06463500 & -- & -- & -- & -- & -- & -- & -- & -- & -- & -- & -- & -- \\
\hline 26 & 06468250 & 1.505 & 0.5 & 3.4 & -1.8 & $11 / 23 / 1992$ & $8 / 25 / 2003$ & 86 & 0 & 0.0487 & 0.1342 & 0.7167 & 0.351 \\
\hline 28 & 06713500 & 2.724 & -4.5 & -2.9 & -5.7 & $4 / 12 / 1993$ & $9 / 22 / 2003$ & 96 & 0 & -0.6341 & 0.1362 & $<0.0001$ & 0.277 \\
\hline 29 & 06714000 & 5.302 & 1.5 & 6.2 & -1.8 & $4 / 14 / 1993$ & $7 / 19 / 2003$ & 146 & 0 & 0.1413 & 0.1783 & 0.4283 & 0.420 \\
\hline 35 & 06753990 & 12.187 & -0.9 & 2.2 & -3.2 & $4 / 13 / 1993$ & $9 / 24 / 2003$ & 76 & 0 & -0.1028 & 0.1588 & 0.5174 & 0.315 \\
\hline 36 & 06754000 & 8.027 & 2.6 & 5.0 & 0.7 & 4/7/1993 & $9 / 23 / 2003$ & 132 & 0 & 0.2437 & 0.0905 & 0.0071 & 0.140 \\
\hline 37 & 06758500 & -- & -- & -- & -- & -- & -- & -- & -- & -- & -- & -- & -- \\
\hline 39 & 06775900 & 0.825 & 0.1 & 1.8 & -1.3 & $11 / 3 / 1992$ & $9 / 8 / 2003$ & 61 & 0 & 0.0137 & 0.0861 & 0.8738 & 0.188 \\
\hline 40 & 06800000 & 4.913 & -1.3 & 1.4 & -3.3 & $4 / 15 / 1993$ & $9 / 16 / 2003$ & 132 & 0 & -0.1405 & 0.1425 & 0.3243 & 0.377 \\
\hline 42 & 06805500 & 3.154 & 0.8 & 3.8 & -1.4 & $11 / 13 / 1992$ & $9 / 19 / 2003$ & 152 & 0 & 0.0876 & 0.1299 & 0.5000 & 0.415 \\
\hline 43 & 06817700 & 4.104 & -6.1 & -2.9 & -7.7 & $11 / 10 / 1992$ & $7 / 24 / 2003$ & 107 & 0 & -1.0453 & 0.3470 & 0.0026 & 0.528 \\
\hline 44 & 06818000 & 3.635 & -4.4 & -3.2 & -5.4 & $11 / 10 / 1992$ & $9 / 24 / 2003$ & 132 & 0 & -0.6500 & 0.1149 & $<0.0001$ & 0.382 \\
\hline 51 & 06902000 & 1.757 & -2.6 & 1.9 & -5.2 & $11 / 12 / 1992$ & $9 / 9 / 2003$ & 125 & 1 & -0.3280 & 0.2606 & 0.2082 & 0.577 \\
\hline 52 & 06905500 & 1.968 & -3.4 & -0.4 & -5.4 & $11 / 12 / 1992$ & $9 / 11 / 2003$ & 107 & 1 & -0.4605 & 0.2096 & 0.0281 & 0.556 \\
\hline 53 & 06921070 & 0.594 & -0.1 & 5.9 & -3.7 & $11 / 17 / 1992$ & $9 / 8 / 2003$ & 90 & 1 & -0.0068 & 0.2555 & 0.9788 & 0.576 \\
\hline 55 & 06926510 & 0.784 & -2.8 & -0.5 & -4.6 & $11 / 17 / 1992$ & $9 / 3 / 2003$ & 67 & 0 & -0.3672 & 0.1596 & 0.0214 & 0.325 \\
\hline 57 & 06930800 & -- & -- & -- & -- & -- & -- & -- & -- & -- & -- & -- & -- \\
\hline 58 & 06934500 & 2.421 & -0.9 & 1.4 & -2.7 & $11 / 24 / 1992$ & $9 / 9 / 2003$ & 132 & 0 & -0.0978 & 0.1241 & 0.4305 & 0.323 \\
\hline \multicolumn{14}{|c|}{ Nitrite plus nitrate } \\
\hline 1 & 06088500 & 1.180 & -4.5 & -2.4 & -5.9 & $10 / 20 / 1992$ & $9 / 10 / 2003$ & 96 & 1 & -0.6739 & 0.1856 & 0.0003 & 0.530 \\
\hline 2 & 06089000 & 0.650 & -0.4 & 4.2 & -3.4 & $10 / 20 / 1992$ & 9/10/2003 & 85 & 0 & -0.0392 & 0.2126 & 0.8538 & 0.543 \\
\hline 5 & 06154410 & -- & -- & -- & -- & -- & -- & -- & -- & -- & -- & -- & -- \\
\hline 6 & 06178000 & -- & -- & -- & -- & -- & -- & -- & -- & -- & -- & -- & -- \\
\hline 11 & 06274300 & 0.385 & -0.3 & 7.4 & -4.4 & $12 / 17 / 1992$ & $8 / 5 / 2003$ & 44 & 0 & -0.0274 & 0.3089 & 0.9295 & 0.401 \\
\hline
\end{tabular}




\begin{tabular}{|c|c|c|c|c|c|c|c|c|c|c|c|c|c|}
\hline \multirow[b]{2}{*}{$\begin{array}{l}\text { Site } \\
\text { num- } \\
\text { ber } \\
\text { (fig. 1) }\end{array}$} & \multirow[b]{2}{*}{$\begin{array}{c}\text { U.S. } \\
\text { Geologcal } \\
\text { Survey } \\
\text { station } \\
\text { number }\end{array}$} & \multirow[b]{2}{*}{$\begin{array}{l}\text { Reference } \\
\text { concen- } \\
\text { tration, in } \\
\text { milligrams } \\
\text { per liter }\end{array}$} & \multicolumn{3}{|c|}{$\begin{array}{l}\text { Trend, in percent } \\
\text { per year }\end{array}$} & \multicolumn{4}{|c|}{$\begin{array}{l}\text { Properties of the calibration } \\
\text { data set }\end{array}$} & \multicolumn{3}{|c|}{$\begin{array}{l}\text { Properties of the modeled } \\
\text { trend term }\end{array}$} & \multirow{2}{*}{$\begin{array}{c}\text { Root } \\
\text { mean } \\
\text { squared } \\
\text { error of } \\
\text { the fitted } \\
\text { model }\end{array}$} \\
\hline & & & $\begin{array}{l}\text { Modeled } \\
\text { estimate }\end{array}$ & $\begin{array}{c}\text { Upper } \\
\text { 95-percent } \\
\text { CI }\end{array}$ & $\begin{array}{l}\text { Lower } \\
\text { 95-per- } \\
\text { cent CI }\end{array}$ & $\begin{array}{l}\text { Start } \\
\text { date }\end{array}$ & $\begin{array}{l}\text { End } \\
\text { date }\end{array}$ & $\begin{array}{c}\text { Number } \\
\text { of } \\
\text { obser- } \\
\text { vations }\end{array}$ & $\begin{array}{l}\text { Number } \\
\text { of } \\
\text { censored } \\
\text { observ- } \\
\text { ations }\end{array}$ & $\begin{array}{l}\text { Coeff- } \\
\text { icient }\end{array}$ & $\begin{array}{l}\text { Standard } \\
\text { deviation }\end{array}$ & $\begin{array}{c}p- \\
\text { value }\end{array}$ & \\
\hline 17 & 06329500 & 0.029 & -4.6 & 3.0 & -7.4 & $10 / 8 / 1992$ & 9/9/2003 & 113 & 25 & -0.6958 & 0.4981 & 0.1625 & 1.062 \\
\hline 18 & 06338490 & 0.072 & -6.7 & -5.1 & -7.7 & $10 / 6 / 1992$ & $8 / 28 / 2003$ & 62 & 0 & -1.3237 & 0.2655 & $<0.0001$ & 0.560 \\
\hline 19 & 06341410 & -- & -- & -- & -- & -- & -- & -- & -- & -- & -- & -- & -- \\
\hline 20 & 06341800 & -- & -- & -- & -- & -- & -- & -- & -- & -- & -- & -- & -- \\
\hline 24 & 06461500 & 0.141 & 5.0 & 13.4 & -0.3 & $10 / 7 / 1992$ & 9/9/2003 & 68 & 3 & 0.4335 & 0.2380 & 0.0686 & 0.545 \\
\hline 25 & 06463500 & -- & -- & -- & -- & -- & -- & -- & -- & -- & -- & -- & -- \\
\hline 26 & 06468250 & 0.034 & -6.4 & 2.7 & -8.6 & $11 / 23 / 1992$ & $8 / 25 / 2003$ & 86 & 43 & -1.1554 & 0.7182 & 0.1077 & 1.388 \\
\hline 28 & 06713500 & 3.290 & -4.9 & -2.9 & -6.3 & $4 / 12 / 1993$ & $9 / 22 / 2003$ & 96 & 0 & -0.7228 & 0.1817 & 0.0001 & 0.252 \\
\hline 29 & 06714000 & 3.679 & 0.1 & 5.3 & -3.3 & $4 / 14 / 1993$ & $7 / 19 / 2003$ & 146 & 0 & 0.0125 & 0.2141 & 0.9535 & 0.359 \\
\hline 33 & 06752260 & 0.244 & -6.0 & -2.4 & -7.7 & $10 / 28 / 1992$ & $9 / 17 / 2003$ & 130 & 1 & -1.0717 & 0.3898 & 0.0060 & 0.795 \\
\hline 34 & 06752280 & 0.627 & 1.2 & 9.1 & -3.2 & $10 / 30 / 1992$ & $9 / 17 / 2003$ & 128 & 1 & 0.1254 & 0.2859 & 0.6611 & 0.757 \\
\hline 35 & 06753990 & 7.886 & 0.0 & 4.7 & -3.2 & $4 / 13 / 1993$ & $9 / 24 / 2003$ & 76 & 0 & -0.0015 & 0.2054 & 0.9940 & 0.327 \\
\hline 36 & 06754000 & 6.163 & 2.4 & 5.0 & 0.2 & 4/7/1993 & $9 / 23 / 2003$ & 132 & 0 & 0.2212 & 0.1017 & 0.0297 & 0.145 \\
\hline 37 & 06758500 & -- & -- & -- & -- & -- & -- & -- & -- & -- & -- & -- & -- \\
\hline 39 & 06775900 & 0.555 & 0.7 & 2.3 & -0.6 & $11 / 3 / 1992$ & $9 / 8 / 2003$ & 61 & 0 & 0.0772 & 0.0762 & 0.3109 & 0.185 \\
\hline 40 & 06800000 & 3.511 & -4.6 & -2.3 & -6.1 & $4 / 15 / 1993$ & $9 / 16 / 2003$ & 132 & 1 & -0.6482 & 0.1897 & 0.0006 & 0.567 \\
\hline 42 & 06805500 & 3.188 & -5.9 & -2.5 & -7.5 & $11 / 13 / 1992$ & $9 / 19 / 2003$ & 152 & 17 & -1.0114 & 0.3537 & 0.0043 & 1.083 \\
\hline 43 & 06817700 & 3.779 & -7.3 & 2.0 & -9.0 & $11 / 10 / 1992$ & $7 / 24 / 2003$ & 108 & 17 & -1.5336 & 0.8796 & 0.0813 & 1.354 \\
\hline 44 & 06818000 & 2.963 & -6.1 & -4.3 & -7.3 & $11 / 10 / 1992$ & $9 / 24 / 2003$ & 132 & 4 & -1.1028 & 0.2376 & $<0.0001$ & 0.793 \\
\hline 51 & 06902000 & 0.254 & -5.6 & 3.3 & -8.2 & $11 / 12 / 1992$ & 9/9/2003 & 126 & 34 & -0.9311 & 0.6327 & 0.1412 & 1.197 \\
\hline 52 & 06905500 & 0.780 & -4.2 & 6.0 & -7.6 & $11 / 12 / 1992$ & $9 / 11 / 2003$ & 107 & 21 & -0.6116 & 0.5669 & 0.2807 & 1.117 \\
\hline 53 & 06921070 & 0.534 & -0.8 & 17.2 & -6.6 & $11 / 17 / 1992$ & $9 / 8 / 2003$ & 90 & 14 & -0.0942 & 0.5845 & 0.8719 & 1.202 \\
\hline 55 & 06926510 & 0.315 & -7.6 & -5.5 & -8.5 & $11 / 17 / 1992$ & $9 / 3 / 2003$ & 67 & 9 & -1.7083 & 0.4124 & $<0.0001$ & 0.789 \\
\hline 57 & 06930800 & 0.245 & -4.6 & -1.7 & -6.4 & $11 / 17 / 1992$ & $9 / 5 / 2003$ & 121 & 2 & -0.6941 & 0.2530 & 0.0061 & 0.621 \\
\hline 58 & 06934500 & 1.690 & -4.4 & -2.0 & -6.0 & $11 / 24 / 1992$ & 9/9/2003 & 133 & 2 & -0.6394 & 0.2037 & 0.0017 & 0.606 \\
\hline
\end{tabular}


Appendix 5. Model output for non-flow-adjusted trends in concentration from 1993 to 2003.—Continued

[CI, confidence interval; --, poor model fit; significant trend if p-value less than 0.05]

\begin{tabular}{|c|c|c|c|c|c|c|c|c|c|c|c|c|c|}
\hline \multirow[b]{2}{*}{$\begin{array}{c}\text { Site } \\
\text { num- } \\
\text { ber } \\
\text { (fig. 1) }\end{array}$} & \multirow[b]{2}{*}{$\begin{array}{c}\text { U.S. } \\
\text { Geologcal } \\
\text { Survey } \\
\text { station } \\
\text { number }\end{array}$} & \multirow{2}{*}{$\begin{array}{c}\text { Reference } \\
\text { concentra- } \\
\text { tion, } \\
\text { in } \\
\text { milligrams } \\
\text { per liter }\end{array}$} & \multicolumn{3}{|c|}{$\begin{array}{c}\text { Trend, in percent } \\
\text { per year }\end{array}$} & \multicolumn{4}{|c|}{$\begin{array}{c}\text { Properties of the calibration } \\
\text { data set }\end{array}$} & \multicolumn{3}{|c|}{$\begin{array}{c}\text { Properties of the modeled } \\
\text { trend term }\end{array}$} & \multirow{2}{*}{$\begin{array}{c}\text { Root } \\
\text { mean } \\
\text { squared } \\
\text { error of } \\
\text { the fitted } \\
\text { model }\end{array}$} \\
\hline & & & $\begin{array}{l}\text { Modeled } \\
\text { estimate }\end{array}$ & $\begin{array}{c}\text { Upper } \\
\text { 95-percent } \\
\text { Cl }\end{array}$ & $\begin{array}{l}\text { Lower } \\
\text { 95-per- } \\
\text { cent Cl }\end{array}$ & $\begin{array}{l}\text { Start } \\
\text { date }\end{array}$ & $\begin{array}{l}\text { End } \\
\text { date }\end{array}$ & $\begin{array}{c}\text { Number } \\
\text { of } \\
\text { obser- } \\
\text { vations }\end{array}$ & $\begin{array}{l}\text { Number } \\
\text { of } \\
\text { censored } \\
\text { observ- } \\
\text { ations }\end{array}$ & $\begin{array}{l}\text { Coeff- } \\
\text { icient }\end{array}$ & $\begin{array}{l}\text { Standard } \\
\text { deviation }\end{array}$ & $\begin{array}{c}p- \\
\text { value }\end{array}$ & \\
\hline \multicolumn{14}{|c|}{ Ammonia } \\
\hline 1 & 06088500 & 0.013 & -7.3 & -5.9 & -8.1 & $10 / 20 / 1992$ & $9 / 10 / 2003$ & 96 & 41 & -1.5993 & 0.2971 & $<0.0001$ & 0.692 \\
\hline 2 & 06089000 & 0.030 & -5.5 & -2.7 & -7.1 & $10 / 20 / 1992$ & $9 / 10 / 2003$ & 84 & 35 & -0.9260 & 0.2966 & 0.0018 & 0.661 \\
\hline 5 & 06154410 & -- & -- & -- & -- & -- & -- & -- & -- & -- & -- & -- & -- \\
\hline 11 & 06274300 & 0.030 & -4.3 & 1.6 & -7.0 & $12 / 17 / 1992$ & $8 / 5 / 2003$ & 44 & 20 & -0.6126 & 0.3938 & 0.1199 & 0.754 \\
\hline 17 & 06329500 & 0.005 & -7.9 & -5.5 & -8.7 & 10/8/1992 & $9 / 9 / 2003$ & 113 & 49 & -1.9645 & 0.5330 & 0.0002 & 1.071 \\
\hline 18 & 06338490 & 0.020 & -6.2 & -0.1 & -8.2 & $10 / 6 / 1992$ & $8 / 28 / 2003$ & 62 & 20 & -1.1308 & 0.5698 & 0.0473 & 1.071 \\
\hline 19 & 06341410 & 0.380 & -6.8 & -2.2 & -8.5 & $10 / 5 / 1992$ & $5 / 27 / 2003$ & 66 & 18 & -1.2880 & 0.5194 & 0.0132 & 1.161 \\
\hline 20 & 06341800 & 0.034 & -3.6 & 3.5 & -6.8 & $10 / 5 / 1992$ & $5 / 28 / 2003$ & 66 & 21 & -0.4776 & 0.4053 & 0.2386 & 0.935 \\
\hline 24 & 06461500 & -- & -- & -- & -- & -- & -- & -- & -- & -- & -- & -- & -- \\
\hline 25 & 06463500 & 0.029 & -4.5 & -1.7 & -6.3 & 10/8/1992 & $2 / 13 / 2003$ & 65 & 24 & -0.6248 & 0.2201 & 0.0045 & 0.463 \\
\hline 26 & 06468250 & 0.039 & -8.0 & -4.9 & -8.9 & $11 / 23 / 1992$ & $8 / 25 / 2003$ & 86 & 33 & -1.9569 & 0.6203 & 0.0016 & 1.517 \\
\hline 28 & 06713500 & 0.023 & -9.1 & -7.8 & -9.4 & $4 / 12 / 1993$ & $9 / 22 / 2003$ & 97 & 38 & -2.9867 & 0.6765 & $<0.0001$ & 1.371 \\
\hline 29 & 06714000 & 0.254 & 8.1 & 28.2 & -1.3 & $4 / 14 / 1993$ & $7 / 19 / 2003$ & 157 & 33 & 0.6055 & 0.3845 & 0.1154 & 1.154 \\
\hline 33 & 06752260 & -- & -- & -- & -- & -- & -- & -- & -- & -- & -- & -- & -- \\
\hline 34 & 06752280 & 0.065 & -6.7 & -4.4 & -7.9 & $10 / 30 / 1992$ & $9 / 17 / 2003$ & 129 & 29 & -1.3113 & 0.3358 & 0.0001 & 0.854 \\
\hline 35 & 06753990 & 0.023 & -8.6 & -5.8 & -9.3 & 4/13/1993 & $9 / 24 / 2003$ & 77 & 17 & -2.3341 & 0.7219 & 0.0012 & 1.510 \\
\hline 36 & 06754000 & 0.445 & 6.7 & 17.5 & 0.2 & 4/7/1993 & $9 / 23 / 2003$ & 131 & 2 & 0.5297 & 0.2614 & 0.0428 & 0.793 \\
\hline 37 & 06758500 & 0.031 & -7.3 & -1.9 & -8.8 & $12 / 10 / 1992$ & $9 / 5 / 2003$ & 46 & 12 & -1.5484 & 0.6756 & 0.0219 & 1.163 \\
\hline 39 & 06775900 & -- & -- & -- & -- & -- & -- & -- & -- & -- & -- & -- & -- \\
\hline 40 & 06800000 & 0.026 & -7.3 & -4.0 & -8.7 & $4 / 15 / 1993$ & $9 / 16 / 2003$ & 132 & 50 & -1.4337 & 0.4601 & 0.0018 & 1.323 \\
\hline 42 & 06805500 & 0.169 & -4.2 & 1.3 & -6.8 & $11 / 13 / 1992$ & $9 / 19 / 2003$ & 152 & 53 & -0.6058 & 0.3775 & 0.1086 & 1.189 \\
\hline 43 & 06817700 & 0.111 & -8.2 & -6.4 & -8.9 & $11 / 10 / 1992$ & $7 / 24 / 2003$ & 108 & 31 & -2.0730 & 0.4719 & $<0.0001$ & 0.995 \\
\hline 44 & 06818000 & 0.133 & -7.2 & -6.0 & -7.9 & $11 / 10 / 1992$ & $9 / 24 / 2003$ & 132 & 35 & -1.5223 & 0.2391 & $<0.0001$ & 0.861 \\
\hline 51 & 06902000 & 0.027 & -6.7 & -3.4 & -8.1 & $11 / 12 / 1992$ & 9/9/2003 & 126 & 54 & -1.2857 & 0.4205 & 0.0022 & 1.083 \\
\hline 52 & 06905500 & 0.064 & -6.8 & -4.2 & -8.0 & $11 / 12 / 1992$ & $9 / 11 / 2003$ & 107 & 29 & -1.3197 & 0.3598 & 0.0002 & 0.977 \\
\hline 53 & 06921070 & 0.017 & -5.6 & -2.6 & -7.2 & 11/17/1992 & 9/8/2003 & 90 & 38 & -0.9199 & 0.2976 & 0.0020 & 0.642 \\
\hline 55 & 06926510 & -- & -- & -- & -- & -- & -- & -- & -- & -- & -- & -- & -- \\
\hline 57 & 06930800 & -- & -- & -- & -- & -- & -- & -- & -- & -- & -- & -- & -- \\
\hline 58 & 06934500 & 0.063 & -7.9 & -6.5 & -8.6 & $11 / 24 / 1992$ & 9/9/2003 & 133 & 67 & -1.9339 & 0.3751 & $<0.0001$ & 0.847 \\
\hline
\end{tabular}


[CI, confidence interval; --, poor model fit; significant trend if p-value less than 0.05]

\begin{tabular}{|c|c|c|c|c|c|c|c|c|c|c|c|c|c|}
\hline \multirow[b]{2}{*}{$\begin{array}{c}\text { Site } \\
\text { num- } \\
\text { ber } \\
\text { (fig. 1) }\end{array}$} & \multirow[b]{2}{*}{$\begin{array}{c}\text { U.S. } \\
\text { Geologcal } \\
\text { Survey } \\
\text { station } \\
\text { number }\end{array}$} & \multirow{2}{*}{$\begin{array}{c}\text { Reference } \\
\text { concentra- } \\
\text { tion, } \\
\text { in } \\
\text { milligrams } \\
\text { per liter }\end{array}$} & \multicolumn{3}{|c|}{$\begin{array}{c}\text { Trend, in percent } \\
\text { per year }\end{array}$} & \multicolumn{4}{|c|}{$\begin{array}{c}\text { Properties of the calibration } \\
\text { data set }\end{array}$} & \multicolumn{3}{|c|}{$\begin{array}{c}\text { Properties of the modeled } \\
\text { trend term }\end{array}$} & \multirow[b]{2}{*}{$\begin{array}{c}\text { Root } \\
\text { mean } \\
\text { squared } \\
\text { error of } \\
\text { the fitted } \\
\text { model }\end{array}$} \\
\hline & & & $\begin{array}{l}\text { Modeled } \\
\text { estimate }\end{array}$ & $\begin{array}{c}\text { Upper } \\
\text { 95-percent } \\
\text { CI } \\
\end{array}$ & $\begin{array}{l}\text { Lower } \\
\text { 95-per- } \\
\text { cent CI }\end{array}$ & $\begin{array}{l}\text { Start } \\
\text { date }\end{array}$ & $\begin{array}{l}\text { End } \\
\text { date }\end{array}$ & $\begin{array}{c}\text { Number } \\
\text { of } \\
\text { obser- } \\
\text { vations }\end{array}$ & $\begin{array}{l}\text { Number } \\
\text { of } \\
\text { censored } \\
\text { observ- } \\
\text { ations }\end{array}$ & $\begin{array}{l}\text { Coeff- } \\
\text { icient }\end{array}$ & $\begin{array}{l}\text { Standard } \\
\text { deviation }\end{array}$ & $\begin{array}{c}p \text { - } \\
\text { value }\end{array}$ & \\
\hline \multicolumn{14}{|c|}{ Total phosphorus } \\
\hline 2 & 06089000 & 0.047 & 0.5 & 8.9 & -4.0 & $10 / 20 / 1992$ & $9 / 10 / 2003$ & 84 & 29 & 0.0547 & 0.3185 & 0.8636 & 0.663 \\
\hline 6 & 06178000 & 0.040 & -1.6 & 5.5 & -5.2 & 10/15/1992 & $8 / 13 / 2003$ & 53 & 21 & -0.1838 & 0.3336 & 0.5817 & 0.539 \\
\hline 17 & 06329500 & 0.184 & 0.3 & 10.1 & -4.5 & $10 / 8 / 1992$ & 9/9/2003 & 113 & 9 & 0.0351 & 0.3611 & 0.9226 & 0.906 \\
\hline 18 & 06338490 & -- & -- & -- & -- & -- & -- & -- & -- & -- & -- & -- & -- \\
\hline 24 & 06461500 & 0.169 & 2.7 & 6.9 & -0.3 & 10/7/1992 & 9/9/2003 & 70 & 0 & 0.2606 & 0.1526 & 0.0878 & 0.376 \\
\hline 25 & 06463500 & 0.203 & 0.5 & 4.2 & -2.3 & $10 / 8 / 1992$ & $2 / 13 / 2003$ & 65 & 0 & 0.0463 & 0.1611 & 0.7740 & 0.359 \\
\hline 28 & 06713500 & -- & -- & -- & -- & -- & -- & -- & -- & -- & -- & -- & -- \\
\hline 29 & 06714000 & 0.841 & 1.6 & 8.3 & -2.6 & 4/14/1993 & $7 / 19 / 2003$ & 157 & 0 & 0.1491 & 0.2370 & 0.5291 & 0.592 \\
\hline 35 & 06753990 & 0.105 & -7.1 & -3.7 & -8.5 & 4/13/1993 & $9 / 24 / 2003$ & 77 & 0 & -1.3346 & 0.4322 & 0.0020 & 0.868 \\
\hline 36 & 06754000 & 0.967 & 3.3 & 5.6 & 1.3 & 4/7/1993 & $9 / 23 / 2003$ & 131 & 0 & 0.2975 & 0.0847 & 0.0004 & 0.288 \\
\hline 37 & 06758500 & 0.414 & -1.9 & 3.4 & -5.0 & $12 / 10 / 1992$ & $9 / 5 / 2003$ & 46 & 0 & -0.2331 & 0.2769 & 0.4000 & 0.485 \\
\hline 39 & 06775900 & -- & -- & -- & -- & -- & -- & -- & -- & -- & -- & -- & -- \\
\hline 40 & 06800000 & 0.455 & 9.5 & 20.2 & 2.7 & 4/15/1993 & $9 / 16 / 2003$ & 129 & 0 & 0.6891 & 0.2259 & 0.0023 & 0.609 \\
\hline 42 & 06805500 & 0.395 & 7.9 & 14.2 & 3.3 & $11 / 13 / 1992$ & 9/19/2003 & 150 & 0 & 0.6172 & 0.1598 & 0.0001 & 0.518 \\
\hline 43 & 06817700 & 0.239 & -2.1 & 6.0 & -5.9 & 11/10/1992 & $7 / 24 / 2003$ & 94 & 2 & -0.2517 & 0.3830 & 0.5111 & 0.643 \\
\hline 44 & 06818000 & 0.200 & 2.1 & 7.2 & -1.4 & 11/10/1992 & $9 / 24 / 2003$ & 119 & 0 & 0.2023 & 0.1906 & 0.2887 & 0.578 \\
\hline 51 & 06902000 & 0.193 & 4.1 & 16.1 & -2.2 & 11/12/1992 & 9/9/2003 & 111 & 1 & 0.3667 & 0.3279 & 0.2634 & 0.580 \\
\hline 52 & 06905500 & 0.175 & -2.7 & 3.3 & -5.9 & $11 / 12 / 1992$ & $9 / 11 / 2003$ & 94 & 6 & -0.3516 & 0.3363 & 0.2959 & 0.678 \\
\hline 53 & 06921070 & 0.090 & -1.7 & 2.3 & -4.3 & $11 / 17 / 1992$ & $9 / 8 / 2003$ & 84 & 23 & -0.2052 & 0.2191 & 0.3492 & 0.428 \\
\hline 55 & 06926510 & -- & -- & -- & -- & -- & -- & -- & -- & -- & -- & -- & -- \\
\hline 57 & 06930800 & -- & -- & -- & -- & -- & -- & -- & -- & -- & -- & -- & -- \\
\hline 58 & 06934500 & 0.317 & 7.1 & 16.8 & 1.0 & $11 / 24 / 1992$ & 9/9/2003 & 131 & 1 & 0.5686 & 0.2375 & 0.0167 & 0.608 \\
\hline \multicolumn{14}{|c|}{ Orthophosphorus } \\
\hline 1 & 06088500 & -- & -- & -- & -- & -- & -- & -- & -- & -- & -- & -- & -- \\
\hline 2 & 06089000 & -- & -- & -- & -- & -- & -- & -- & -- & -- & -- & -- & -- \\
\hline 5 & 06154410 & -- & -- & -- & -- & -- & -- & -- & -- & -- & -- & -- & -- \\
\hline 6 & 06178000 & 0.010 & -5.3 & -0.3 & -7.5 & $10 / 15 / 1992$ & $8 / 13 / 2003$ & 53 & 22 & -0.8436 & 0.4145 & 0.0419 & 0.653 \\
\hline 11 & 06274300 & 0.014 & -5.9 & -2.0 & -7.7 & $12 / 17 / 1992$ & $8 / 5 / 2003$ & 44 & 22 & -0.9780 & 0.3778 & 0.0096 & 0.612 \\
\hline 17 & 06329500 & 0.004 & -6.3 & 2.2 & -8.5 & $10 / 8 / 1992$ & 9/9/2003 & 113 & 57 & -1.1773 & 0.7103 & 0.0975 & 1.140 \\
\hline
\end{tabular}


Appendix 5. Model output for non-flow-adjusted trends in concentration from 1993 to 2003._- Continued

[CI, confidence interval; --, poor model fit; significant trend if p-value less than 0.05$]$

\begin{tabular}{|c|c|c|c|c|c|c|c|c|c|c|c|c|c|}
\hline \multirow[b]{2}{*}{$\begin{array}{c}\text { Site } \\
\text { num- } \\
\text { ber } \\
\text { (fig. 1) }\end{array}$} & \multirow[b]{2}{*}{$\begin{array}{c}\text { U.S. } \\
\text { Geologcal } \\
\text { Survey } \\
\text { station } \\
\text { number }\end{array}$} & \multirow{2}{*}{$\begin{array}{c}\text { Reference } \\
\text { concentra- } \\
\text { tion, } \\
\text { in } \\
\text { milligrams } \\
\text { per liter }\end{array}$} & \multicolumn{3}{|c|}{$\begin{array}{c}\text { Trend, in percent } \\
\text { per year }\end{array}$} & \multicolumn{4}{|c|}{$\begin{array}{c}\text { Properties of the calibration } \\
\text { data set }\end{array}$} & \multicolumn{3}{|c|}{$\begin{array}{c}\text { Properties of the modeled } \\
\text { trend term }\end{array}$} & \multirow{2}{*}{$\begin{array}{c}\text { Root } \\
\text { mean } \\
\text { squared } \\
\text { error of } \\
\text { the fitted } \\
\text { model }\end{array}$} \\
\hline & & & $\begin{array}{l}\text { Modeled } \\
\text { estimate }\end{array}$ & $\begin{array}{c}\text { Upper } \\
\text { 95-percent } \\
\text { CI } \\
\end{array}$ & $\begin{array}{l}\text { Lower } \\
\text { 95-per- } \\
\text { cent CI }\end{array}$ & $\begin{array}{l}\text { Start } \\
\text { date }\end{array}$ & $\begin{array}{l}\text { End } \\
\text { date }\end{array}$ & $\begin{array}{c}\text { Number } \\
\text { of } \\
\text { obser- } \\
\text { vations }\end{array}$ & $\begin{array}{c}\text { of } \\
\text { censored } \\
\text { observ- } \\
\text { ations } \\
\end{array}$ & $\begin{array}{l}\text { Coeff- } \\
\text { icient }\end{array}$ & $\begin{array}{l}\text { Standard } \\
\text { deviation }\end{array}$ & $\begin{array}{c}p \text { - } \\
\text { value }\end{array}$ & \\
\hline 18 & 06338490 & -- & -- & -- & -- & -- & -- & -- & -- & -- & -- & -- & -- \\
\hline 19 & 06341410 & 0.088 & -6.1 & -3.0 & -7.7 & 10/5/1992 & $5 / 27 / 2003$ & 66 & 3 & -1.0483 & 0.3359 & 0.0018 & 0.842 \\
\hline 20 & 06341800 & 0.017 & 1.1 & 15.9 & -5.0 & 10/5/1992 & $5 / 28 / 2003$ & 66 & 16 & 0.1143 & 0.4475 & 0.7984 & 1.141 \\
\hline 24 & 06461500 & 0.045 & 1.6 & 6.2 & -1.7 & 10/7/1992 & $9 / 9 / 2003$ & 69 & 2 & 0.1577 & 0.1822 & 0.3868 & 0.493 \\
\hline 25 & 06463500 & -- & -- & -- & -- & -- & -- & -- & -- & -- & -- & -- & -- \\
\hline 26 & 06468250 & 0.140 & -6.6 & -2.2 & -8.3 & $11 / 23 / 1992$ & $8 / 25 / 2003$ & 86 & 9 & -1.2376 & 0.4922 & 0.0120 & 1.117 \\
\hline 28 & 06713500 & 0.243 & -5.7 & -4.6 & -6.6 & $4 / 12 / 1993$ & $9 / 22 / 2003$ & 96 & 0 & -0.9175 & 0.1303 & $<0.0001$ & 0.274 \\
\hline 29 & 06714000 & 0.539 & -0.8 & 5.9 & -4.7 & 4/14/1993 & $7 / 19 / 2003$ & 156 & 1 & -0.0910 & 0.2894 & 0.7531 & 0.431 \\
\hline 33 & 06752260 & -- & -- & -- & -- & -- & -- & -- & -- & -- & -- & -- & -- \\
\hline 34 & 06752280 & 0.034 & 6.6 & 27.1 & -2.3 & 10/30/1992 & $9 / 17 / 2003$ & 130 & 39 & 0.5441 & 0.4229 & 0.1982 & 1.127 \\
\hline 35 & 06753990 & 0.005 & -7.1 & -2.0 & -8.8 & $4 / 13 / 1993$ & $9 / 24 / 2003$ & 77 & 15 & -1.3742 & 0.5797 & 0.0178 & 1.224 \\
\hline 36 & 06754000 & 0.757 & 4.2 & 7.7 & 1.3 & 4/7/1993 & $9 / 23 / 2003$ & 132 & 0 & 0.3614 & 0.1178 & 0.0022 & 0.318 \\
\hline 37 & 06758500 & -- & -- & -- & -- & -- & -- & -- & -- & -- & -- & -- & -- \\
\hline 39 & 06775900 & -- & -- & -- & -- & -- & -- & -- & -- & -- & -- & -- & -- \\
\hline 40 & 06800000 & 0.185 & 5.3 & 11.5 & 1.0 & $4 / 15 / 1993$ & $9 / 16 / 2003$ & 132 & 1 & 0.4419 & 0.1772 & 0.0126 & 0.520 \\
\hline 42 & 06805500 & -- & -- & -- & -- & -- & -- & -- & -- & -- & -- & -- & -- \\
\hline 43 & 06817700 & 0.102 & -7.3 & -5.1 & -8.3 & 11/10/1992 & $7 / 24 / 2003$ & 108 & 3 & -1.4990 & 0.3631 & $<0.0001$ & 0.749 \\
\hline 44 & 06818000 & 0.109 & -5.5 & -4.0 & -6.5 & 11/10/1992 & $9 / 24 / 2003$ & 130 & 2 & -0.8990 & 0.1644 & $<0.0001$ & 0.499 \\
\hline 51 & 06902000 & 0.043 & -4.4 & 0.8 & -6.9 & $11 / 12 / 1992$ & $9 / 9 / 2003$ & 126 & 27 & -0.6416 & 0.3688 & 0.0819 & 0.624 \\
\hline 52 & 06905500 & 0.057 & -8.5 & -7.8 & -8.9 & $11 / 12 / 1992$ & $9 / 11 / 2003$ & 106 & 21 & -2.5777 & 0.3669 & $<0.0001$ & 0.736 \\
\hline 53 & 06921070 & 0.024 & -3.8 & 0.9 & -6.3 & $11 / 17 / 1992$ & $9 / 8 / 2003$ & 90 & 16 & -0.5319 & 0.3171 & 0.0936 & 0.670 \\
\hline 55 & 06926510 & -- & -- & -- & -- & -- & -- & -- & -- & -- & -- & -- & -- \\
\hline 57 & 06930800 & 0.017 & -5.7 & -3.9 & -6.9 & $11 / 17 / 1992$ & $9 / 5 / 2003$ & 121 & 46 & -0.9520 & 0.2073 & $<0.0001$ & 0.500 \\
\hline 58 & 06934500 & 0.074 & -1.0 & 1.7 & -3.1 & $11 / 24 / 1992$ & 9/9/2003 & 133 & 0 & -0.1173 & 0.1469 & 0.4246 & 0.443 \\
\hline \multicolumn{14}{|c|}{ Suspended Sediment } \\
\hline 1 & 06088500 & 127.683 & -5.9 & -4.3 & -7.0 & $10 / 20 / 1992$ & $9 / 10 / 2003$ & 96 & 0 & -1.0385 & 0.2104 & $<0.0001$ & 0.536 \\
\hline 2 & 06089000 & 37.691 & -4.3 & -1.9 & -6.0 & $10 / 20 / 1992$ & $9 / 10 / 2003$ & 85 & 0 & -0.6357 & 0.2095 & 0.0024 & 0.523 \\
\hline 3 & 06115200 & 318.141 & 12.7 & 52.3 & -1.4 & $11 / 18 / 1992$ & $7 / 21 / 2003$ & 55 & 0 & 0.8584 & 0.5236 & 0.1011 & 1.095 \\
\hline 4 & 06130500 & 227.061 & -7.8 & -6.1 & -8.6 & 10/6/1992 & $6 / 17 / 2003$ & 74 & 0 & -1.8127 & 0.3797 & $<0.0001$ & 0.669 \\
\hline 5 & 06154410 & 29.298 & -0.1 & 8.1 & -4.4 & $12 / 3 / 1992$ & $6 / 25 / 2003$ & 38 & 0 & -0.0064 & 0.3184 & 0.9839 & 0.544 \\
\hline 6 & 06178000 & 34.257 & -0.8 & 14.7 & -6.3 & $10 / 15 / 1992$ & $8 / 13 / 2003$ & 51 & 0 & -0.0945 & 0.5341 & 0.8596 & 0.980 \\
\hline
\end{tabular}


Appendix 5. Model output for non-flow-adjusted trends in concentration from 1993 to 2003.—Continued

[CI, confidence interval; --, poor model fit; significant trend if p-value less than 0.05]

\begin{tabular}{|c|c|c|c|c|c|c|c|c|c|c|c|c|c|}
\hline \multirow[b]{2}{*}{$\begin{array}{c}\text { Site } \\
\text { num- } \\
\text { ber } \\
\text { (fig. 1) }\end{array}$} & \multirow[b]{2}{*}{$\begin{array}{c}\text { U.S. } \\
\text { Geologcal } \\
\text { Survey } \\
\text { station } \\
\text { number }\end{array}$} & \multirow{2}{*}{$\begin{array}{c}\text { Reference } \\
\text { concentra- } \\
\text { tion, } \\
\text { in } \\
\text { milligrams } \\
\text { per liter }\end{array}$} & \multicolumn{3}{|c|}{$\begin{array}{c}\text { Trend, in percent } \\
\text { per year }\end{array}$} & \multicolumn{4}{|c|}{$\begin{array}{c}\text { Properties of the calibration } \\
\text { data set }\end{array}$} & \multicolumn{3}{|c|}{$\begin{array}{l}\text { Properties of the modeled } \\
\text { trend term }\end{array}$} & \multirow{2}{*}{$\begin{array}{c}\text { Root } \\
\text { mean } \\
\text { squared } \\
\text { error of } \\
\text { the fitted } \\
\text { model }\end{array}$} \\
\hline & & & $\begin{array}{l}\text { Modeled } \\
\text { estimate }\end{array}$ & $\begin{array}{c}\text { Upper } \\
\text { 95-percent } \\
\text { CI }\end{array}$ & $\begin{array}{l}\text { Lower } \\
\text { 95-per- } \\
\text { cent CI }\end{array}$ & $\begin{array}{l}\text { Start } \\
\text { date }\end{array}$ & $\begin{array}{l}\text { End } \\
\text { date }\end{array}$ & $\begin{array}{c}\text { Number } \\
\text { of } \\
\text { obser- } \\
\text { vations }\end{array}$ & $\begin{array}{l}\text { of } \\
\text { censored } \\
\text { observ- } \\
\text { ations }\end{array}$ & $\begin{array}{l}\text { Coeff- } \\
\text { icient }\end{array}$ & $\begin{array}{l}\text { Standard } \\
\text { deviation }\end{array}$ & $\begin{array}{c}p- \\
\text { value }\end{array}$ & \\
\hline 17 & 06329500 & 95.284 & -5.9 & -3.1 & -7.4 & $10 / 8 / 1992$ & $9 / 9 / 2003$ & 137 & 0 & -1.0298 & 0.3152 & 0.0011 & 0.846 \\
\hline 21 & 06436180 & 22.597 & -5.2 & -0.6 & -7.3 & $10 / 13 / 1992$ & $9 / 8 / 2003$ & 59 & 0 & -0.8341 & 0.3892 & 0.0321 & 0.851 \\
\hline 22 & 06441500 & 630.768 & -8.1 & -3.4 & -9.2 & 2/4/1993 & $7 / 2 / 2003$ & 80 & 0 & -1.8479 & 0.7178 & 0.0101 & 1.257 \\
\hline 23 & 06452000 & 509.729 & -5.0 & 2.3 & -7.6 & $10 / 8 / 1992$ & 9/10/2003 & 103 & 0 & -0.7855 & 0.5155 & 0.1276 & 1.135 \\
\hline 26 & 06468250 & 37.495 & 29.4 & 70.7 & 9.4 & $11 / 23 / 1992$ & $8 / 25 / 2003$ & 83 & 0 & 1.4262 & 0.3703 & 0.0001 & 0.905 \\
\hline 28 & 06713500 & 0.204 & -3.9 & 10.4 & -7.9 & $4 / 12 / 1993$ & $9 / 22 / 2003$ & 90 & 0 & -0.5155 & 0.6391 & 0.4200 & 1.259 \\
\hline 35 & 06753990 & 2.536 & -7.9 & -5.1 & -8.9 & 4/13/1993 & $9 / 24 / 2003$ & 74 & 0 & -1.7306 & 0.4910 & 0.0004 & 1.017 \\
\hline 36 & 06754000 & 124.159 & -5.6 & -2.6 & -7.3 & 4/7/1993 & $9 / 23 / 2003$ & 130 & 0 & -0.8806 & 0.2840 & 0.0019 & 0.738 \\
\hline 39 & 06775900 & 872.600 & -5.8 & -4.4 & -6.8 & $11 / 3 / 1992$ & $9 / 8 / 2003$ & 51 & 0 & -0.9874 & 0.1697 & $<0.0001$ & 0.396 \\
\hline 40 & 06800000 & 290.632 & -8.5 & -7.1 & -9.1 & $4 / 15 / 1993$ & $9 / 16 / 2003$ & 129 & 0 & -2.1694 & 0.4211 & $<0.0001$ & 0.964 \\
\hline 42 & 06805500 & 638.672 & -4.5 & -0.7 & -6.6 & 11/13/1992 & $9 / 19 / 2003$ & 146 & 0 & -0.6638 & 0.2955 & 0.0247 & 0.826 \\
\hline 58 & 06934500 & 519.821 & -6.8 & -4.5 & -8.2 & $5 / 13 / 1993$ & $7 / 8 / 2003$ & 125 & 0 & -1.1873 & 0.2910 & $<0.0001$ & 0.587 \\
\hline
\end{tabular}


Appendix 6. Model output for nitrate loads in surface water and base flow from 1993 to 2003

[SW, surface water; GW, ground water; AMLE, adjusted maximum likelihood estimation; LAD, least absolute deviation; $\mathrm{R}^{2}$, coefficient of determination between observed and predicted concentrations; na, not applicable]

\begin{tabular}{|c|c|c|c|c|c|c|c|c|c|c|c|}
\hline \multirow[b]{2}{*}{$\begin{array}{c}\text { Site } \\
\text { number } \\
\text { (fig. 1) }\end{array}$} & \multirow[b]{2}{*}{$\begin{array}{c}\text { U.S. } \\
\text { Geological } \\
\text { Survey } \\
\text { station } \\
\text { number }\end{array}$} & \multirow[b]{2}{*}{$\begin{array}{l}\text { Site } \\
\text { Type }\end{array}$} & \multicolumn{4}{|c|}{$\begin{array}{l}\text { Properties of the calibration } \\
\text { data set }\end{array}$} & \multicolumn{5}{|c|}{ Properties of the fitted model } \\
\hline & & & $\begin{array}{l}\text { Start } \\
\text { date }\end{array}$ & $\begin{array}{l}\text { End } \\
\text { date }\end{array}$ & $\begin{array}{c}\text { Num- } \\
\text { ber of } \\
\text { observ- } \\
\text { ations }\end{array}$ & $\begin{array}{c}\text { Number of } \\
\text { censored } \\
\text { observ- } \\
\text { ations }\end{array}$ & $\begin{array}{l}\text { Model } \\
\text { type }\end{array}$ & $\begin{array}{l}\text { Mean load } \\
\text { (kilograms } \\
\text { per year) }\end{array}$ & $\begin{array}{l}\text { Model } \\
\text { standard } \\
\text { error (kilo- } \\
\text { grams per } \\
\text { year) }\end{array}$ & $\begin{array}{l}\text { Ratio of } \\
\text { standard } \\
\text { error to } \\
\text { mean load } \\
\text { (percent) }\end{array}$ & $\mathbf{R}^{2}$ \\
\hline \multirow[t]{2}{*}{1} & 06088500 & SW & $10 / 20 / 1992$ & $9 / 10 / 2003$ & 96 & 1 & AMLE & 485.8 & 30.54 & 6.3 & 55 \\
\hline & & GW & $1 / 15 / 1993$ & $9 / 10 / 2003$ & 63 & 0 & LAD & 415.6 & 16.93 & 4.1 & na \\
\hline \multirow[t]{2}{*}{39} & 06775900 & SW & $11 / 3 / 1992$ & $9 / 8 / 2003$ & 61 & 0 & AMLE & 268.2 & 9.183 & 3.4 & 51 \\
\hline & & GW & $2 / 23 / 1993$ & $9 / 8 / 2003$ & 59 & 0 & LAD & 269.1 & 9.272 & 3.4 & na \\
\hline \multirow[t]{2}{*}{53} & 06921070 & SW & $11 / 17 / 1992$ & $9 / 8 / 2003$ & 90 & 14 & AMLE & 1,686 & 755.3 & 45 & 85 \\
\hline & & GW & $3 / 10 / 1993$ & $9 / 8 / 2003$ & 66 & 14 & AMLE & 260.1 & 81.72 & 31 & 82 \\
\hline
\end{tabular}


Appendix 7. Model output for flow-adjusted trends in concentration from 1985 to 2003

Appendix 7a. Median concentrations and trend periods.

[--, not derived; NS, not significant; significant trend if p-value less than 0.05]

\begin{tabular}{|c|c|c|c|c|c|c|}
\hline $\begin{array}{c}\text { Site } \\
\text { number } \\
\text { (fig. 1) }\end{array}$ & $\begin{array}{l}\text { U.S. Geological } \\
\text { Survey station } \\
\text { number }\end{array}$ & $\begin{array}{l}\text { Number } \\
\text { of observ- } \\
\text { ations }\end{array}$ & $\begin{array}{l}\text { Median concentra- } \\
\text { tion, in milligrams } \\
\text { per liter }\end{array}$ & $\begin{array}{c}\text { Trend period } \\
\text { (direction of trend) }\end{array}$ & $\begin{array}{l}\text { Model } \\
\text { statistic }\end{array}$ & $\begin{array}{c}p- \\
\text { value }\end{array}$ \\
\hline \multicolumn{7}{|c|}{ Total nitrogen } \\
\hline 17 & 06329500 & 156 & 0.69 & $\begin{array}{c}\text { 1985-91 (downward) and } \\
1992-2003 \text { (upward) }\end{array}$ & 33.06 & $<0.0001$ \\
\hline 18 & 06338490 & 104 & 0.29 & 1985-96 (downward) & 19.69 & $<.00001$ \\
\hline 39 & 06775900 & 93 & 0.78 & 1985-91 (downward) & 5.05 & .025 \\
\hline 42 & 06805500 & 294 & 2.6 & 1997-2003 (upward) & 11.97 & .0005 \\
\hline 44 & 06818000 & 214 & 2.2 & $\begin{array}{c}1992-96 \text { (downward) and } \\
\text { 1997-2003 (upward) }\end{array}$ & 16.61 & .0002 \\
\hline 51 & 06902000 & 189 & 1.4 & -- & -- & NS \\
\hline 55 & 06926510 & 114 & .68 & -- & -- & NS \\
\hline 57 & 06930800 & 183 & .48 & 1985-91 (downward) & 10.12 & .0015 \\
\hline 58 & 06934500 & 261 & 2.0 & 1997-2003 (upward) & 6.29 & .012 \\
\hline \multicolumn{7}{|c|}{ Nitrite plus nitrate } \\
\hline 25 & 06463500 & 155 & 1.8 & 1985-96 (upward) & 32.42 & $<.00001$ \\
\hline 33 & 06752260 & 192 & 0.26 & 1997-2003 (downward) & 58.02 & $<.00001$ \\
\hline 34 & 06752280 & 194 & 0.82 & 1997-2003 (downward) & 38.32 & $<.00001$ \\
\hline 37 & 06758500 & 99 & 4.8 & $\begin{array}{l}\text { 1985-91 (downward) and } \\
\text { 1997-2003 (upward) }\end{array}$ & 19.10 & .00007 \\
\hline 39 & 06775900 & 93 & 0.48 & 1992-2003 (upward) & 4.83 & .028 \\
\hline \multicolumn{7}{|c|}{ Total phosphorus } \\
\hline 24 & 06461500 & 150 & 0.12 & $\begin{array}{l}\text { 1985-91 (upward), 1992-96 } \\
\text { (downward), and 1997- } \\
2003 \text { (upward) }\end{array}$ & 12.08 & .0071 \\
\hline 25 & 06463500 & 142 & 0.20 & 1985-91 (downward) & 5.52 & .019 \\
\hline 39 & 06775900 & 93 & 0.20 & 1992-2003 (upward) & 5.61 & .018 \\
\hline 42 & 06805500 & 292 & 0.40 & 1985-2003 (upward) & 5.37 & .020 \\
\hline 44 & 06818000 & 201 & 0.19 & 1985-2003 (upward) & 9.96 & .0016 \\
\hline 51 & 06902000 & 175 & 0.19 & -- & -- & NS \\
\hline 58 & 06934500 & 261 & 0.21 & 1985-2003 (upward) & 10.82 & .0010 \\
\hline \multicolumn{7}{|c|}{ Orthophosphorus } \\
\hline 39 & 06775900 & 93 & 0.13 & -- & -- & NS \\
\hline 42 & 06805500 & 212 & 0.18 & -- & -- & NS \\
\hline 44 & 06818000 & 212 & 0.08 & -- & -- & NS \\
\hline 58 & 06934500 & 275 & 0.08 & 1985-91 (upward) & 4.32 & .038 \\
\hline \multicolumn{7}{|c|}{ Suspended sediment } \\
\hline 3 & 06115200 & 114 & 218 & $\begin{array}{l}\text { 1985-96 (downward) and } \\
\text { 1997-2003 (upward) }\end{array}$ & 7.83 & .020 \\
\hline 4 & 06130500 & 161 & 119 & 1985-91 (downward) & 6.27 & .012 \\
\hline 17 & 06329500 & 201 & 232 & -- & -- & NS \\
\hline 22 & 06441500 & 129 & 4,120 & -- & -- & NS \\
\hline 23 & 06452000 & 183 & 3,600 & -- & -- & NS \\
\hline 42 & 06805500 & 250 & 494 & -- & -- & NS \\
\hline 58 & 06934500 & 214 & 322 & $\begin{array}{l}\text { 1985-91 (upward) and } \\
1992-2003 \text { (downward) }\end{array}$ & 19.34 & .00006 \\
\hline
\end{tabular}


Appendix 7b. Estimated trend magnitudes and 95-percent confidence intervals.

[--, not derived]

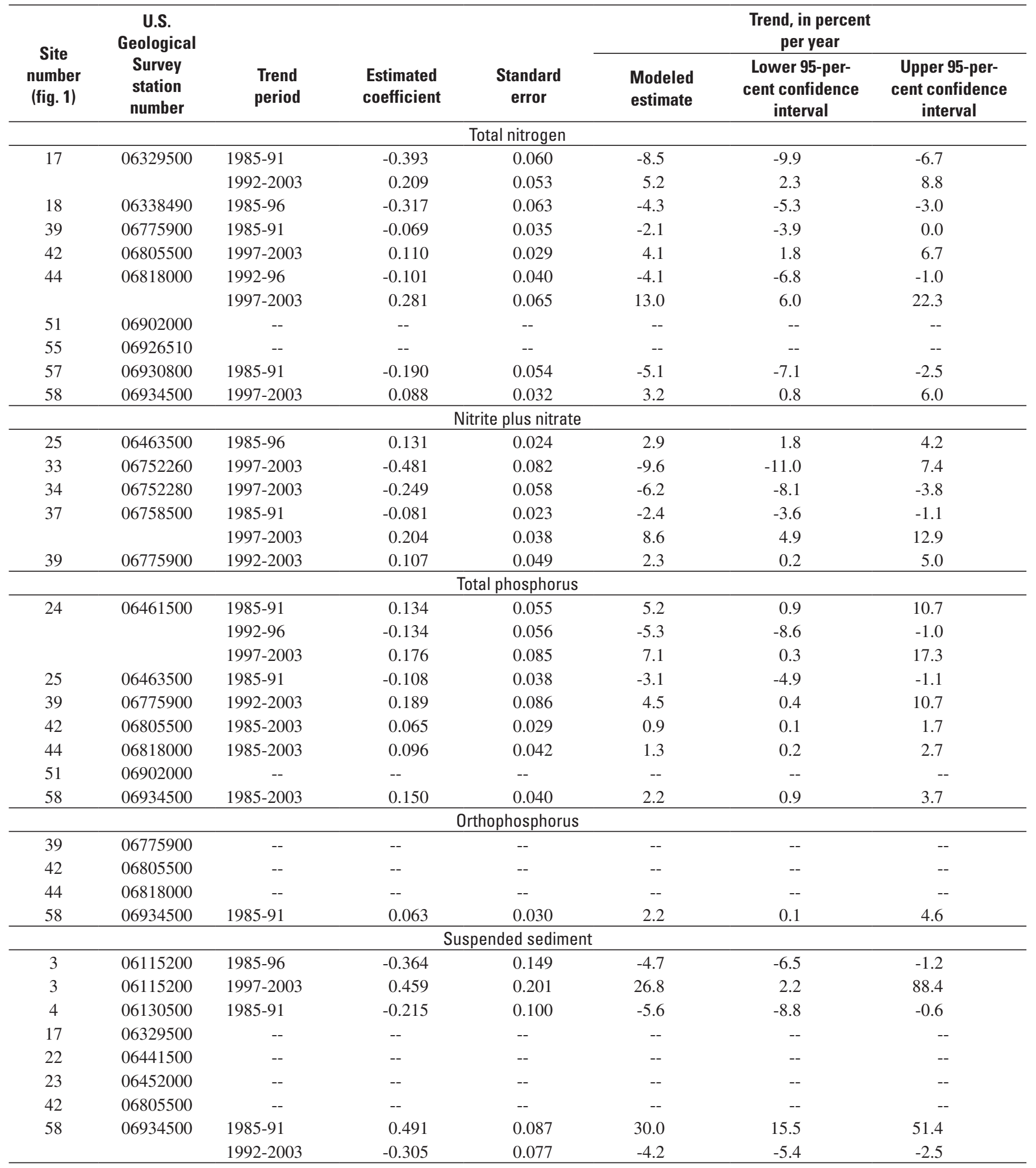


[--, poor model fit; AMLE, adjusted maximum-likelihood estimation; LAD, least absolute deviation; $\mathrm{R}^{2}$, coefficient of determination between observed and predicted concentrations; na, not applicable.]

\begin{tabular}{|c|c|c|c|c|c|c|c|c|c|c|c|c|c|}
\hline \multirow[b]{2}{*}{$\begin{array}{c}\text { Site } \\
\text { num- } \\
\text { ber } \\
\text { (fig. 1) }\end{array}$} & \multirow[b]{2}{*}{$\begin{array}{c}\text { U.S. } \\
\text { Geological } \\
\text { Survey } \\
\text { station } \\
\text { number }\end{array}$} & \multirow[b]{2}{*}{$\begin{array}{c}\text { Contributing } \\
\text { drainage } \\
\text { area, } \\
\text { in square } \\
\text { kilometers }\end{array}$} & \multicolumn{4}{|c|}{ Properties of the calibration data set } & \multicolumn{2}{|c|}{$\begin{array}{c}\text { Properties of the prediction } \\
\text { data set }\end{array}$} & \multicolumn{5}{|c|}{$\begin{array}{c}\text { Properties of the } \\
\text { fitted model }\end{array}$} \\
\hline & & & $\begin{array}{l}\text { Start } \\
\text { date }\end{array}$ & $\begin{array}{l}\text { End } \\
\text { date }\end{array}$ & $\begin{array}{c}\text { Number } \\
\text { of } \\
\text { observ- } \\
\text { ations }\end{array}$ & $\begin{array}{c}\text { Number } \\
\text { of cens- } \\
\text { ored } \\
\text { observ- } \\
\text { ations }\end{array}$ & $\begin{array}{c}\text { Years } \\
\text { from which mean } \\
\text { daily streamflow } \\
\text { was derived }\end{array}$ & $\begin{array}{c}\text { Artificial } \\
\text { start } \\
\text { date }^{1}\end{array}$ & $\begin{array}{c}\text { Model } \\
\text { type }\end{array}$ & $\begin{array}{l}\text { Mean } \\
\text { load, in } \\
\text { kilograms } \\
\text { per day }\end{array}$ & $\begin{array}{l}\text { Model } \\
\text { standard } \\
\text { error, in } \\
\text { kilograms } \\
\text { per day }\end{array}$ & $\begin{array}{c}\text { Ratio of } \\
\text { standard } \\
\text { error to } \\
\text { mean load } \\
\text { (percent) }\end{array}$ & $\mathbf{R}^{2}$ \\
\hline 4 & 06130500 & 20,310 & $3 / 19 / 1991$ & $3 / 31 / 1994$ & 41 & 0 & $1953,1957,1980$ & $1 / 1 / 1991$ & AMLE & $5.3 \times 10^{5}$ & $9.3 \times 10^{4}$ & 17 & 97 \\
\hline 7 & 06187915 & 80.77 & 1/21/1999 & $9 / 24 / 2001$ & 34 & 0 & 1999, 2000, 2002 & $1 / 1 / 1999$ & AMLE & $7.2 \times 10^{3}$ & $2.1 \times 10^{3}$ & 29 & 95 \\
\hline 8 & 06191500 & 6,780 & 1/21/1999 & $9 / 24 / 2001$ & 36 & 0 & $1921,1963,1983$ & $1 / 1 / 1999$ & AMLE & $6.8 \times 10^{5}$ & $1.3 \times 10^{5}$ & 20 & 96 \\
\hline 9 & 06208500 & 5,235 & $1 / 29 / 1999$ & $11 / 14 / 2001$ & 41 & 0 & $1926,1949,1998$ & $1 / 1 / 1999$ & LAD & $2.2 \times 10^{6}$ & $1.6 \times 10^{6}$ & 72 & na \\
\hline 10 & 06214500 & 29,530 & 1/19/1999 & $9 / 25 / 2001$ & 37 & 0 & 1938, 1944, 1963 & 1/1/1999 & AMLE & $5.7 \times 10^{6}$ & $2.2 \times 10^{6}$ & 38 & 89 \\
\hline 12 & 06279500 & 40,810 & 1/20/1999 & $10 / 22 / 2001$ & 46 & 0 & $1962,1982,1996$ & 1/1/1999 & LAD & $4.5 \times 10^{6}$ & $1.9 \times 10^{6}$ & 41 & na \\
\hline 13 & 06295000 & 102,100 & 1/26/1999 & $1 / 17 / 2002$ & 46 & 0 & 1979,1980 & 1/1/1999 & AMLE & $4.2 \times 10^{6}$ & $8.5 \times 10^{5}$ & 20 & 86 \\
\hline 14 & 06298000 & 533.3 & 1/14/1999 & $9 / 12 / 2001$ & 38 & 0 & $1977,1983,1986$ & 1/1/1999 & LAD & $1.1 \times 10^{4}$ & $1.4 \times 10^{3}$ & 13 & na \\
\hline 15 & 06324970 & 3,202 & 1/28/1999 & $1 / 16 / 2002$ & 44 & 0 & $1974,1976,1987$ & 1/1/1999 & AMLE & $1.1 \times 10^{5}$ & $7.9 \times 10^{4}$ & 74 & 93 \\
\hline 16 & 06326500 & 33,830 & -- & -- & -- & -- & -- & -- & AMLE & -- & -- & -- & -- \\
\hline 17 & 06329500 & 177,100 & -- & -- & -- & -- & -- & -- & AMLE & -- & -- & -- & -- \\
\hline 22 & 06441500 & 8,044 & $2 / 4 / 1993$ & $2 / 22 / 1996$ & 33 & 0 & $1943,1968,1975$ & $1 / 1 / 1993$ & AMLE & $2.2 \times 10^{6}$ & $8.7 \times 10^{5}$ & 40 & 93 \\
\hline 23 & 06452000 & 25,730 & $12 / 8 / 1993$ & 11/27/1996 & 34 & 0 & $1946,1955,1965$ & 1/1/1994 & AMLE & $1.5 \times 10^{7}$ & $4.4 \times 10^{6}$ & 30 & 89 \\
\hline 27 & 06705500 & 193.1 & $10 / 18 / 1994$ & 9/29/1997 & 66 & 0 & 1917, 1996 & 1/1/1995 & LAD & $7.4 \times 10^{3}$ & $2.2 \times 10^{3}$ & 30 & na \\
\hline 29 & 06714000 & 9,996 & 4/14/1993 & 4/9/1996 & 62 & 0 & $1922,1929,1971$ & 1/1/1993 & AMLE & $1.5 \times 10^{5}$ & $3.8 \times 10^{4}$ & 25 & 78 \\
\hline 30 & 06714400 & 30.55 & $10 / 18 / 1994$ & 10/1/1997 & 74 & 0 & 1995,1996 & 1/1/1995 & AMLE & $1.2 \times 10^{3}$ & $3.0 \times 10^{2}$ & 24 & 71 \\
\hline 31 & 06714800 & 31.07 & $10 / 18 / 1994$ & $10 / 16 / 1997$ & 59 & 0 & 1996, 1997, 1999 & $1 / 1 / 1995$ & AMLE & $8.1 \times 10^{2}$ & $1.5 \times 10^{2}$ & 18 & 91 \\
\hline 32 & 06720500 & 12,340 & 11/9/1992 & 9/6/1995 & 64 & 0 & $1936,1982,1989$ & $1 / 1 / 1993$ & AMLE & $8.5 \times 10^{4}$ & $1.7 \times 10^{4}$ & 19 & 82 \\
\hline 36 & 06754000 & 25,010 & 4/7/1993 & 2/8/1996 & 52 & 0 & 1906, 1967, 2001 & $1 / 1 / 1993$ & AMLE & $2.8 \times 10^{5}$ & $3.1 \times 10^{4}$ & 11 & 92 \\
\hline 38 & 06759910 & 43,030 & 4/8/1993 & 2/9/1996 & 51 & 0 & 1993, 1996, 1997 & 1/1/1993 & AMLE & $7.9 \times 10^{5}$ & $1.8 \times 10^{5}$ & 22 & 92 \\
\hline 40 & 06800000 & 952.7 & 4/30/1997 & $4 / 25 / 2000$ & 40 & 0 & 1958, 1966, 1989 & 1/1/1992 & AMLE & $1.3 \times 10^{6}$ & $7.1 \times 10^{5}$ & 57 & 89 \\
\hline 41 & 06800500 & 15,200 & $9 / 5 / 1991$ & 9/12/1994 & 41 & 0 & $1959,1972,2002$ & 1/1/1992 & AMLE & $4.8 \times 10^{6}$ & $6.4 \times 10^{5}$ & 13 & 96 \\
\hline 42 & 06805500 & 183,800 & 8/16/1991 & $8 / 24 / 1994$ & 104 & 0 & 1969, 1974, 1979 & 1/1/1992 & AMLE & $1.0 \times 10^{7}$ & $1.6 \times 10^{6}$ & 15 & 84 \\
\hline 45 & 06879100 & 116,200 & $5 / 14 / 1987$ & 4/27/1990 & 48 & 0 & 1980, 1992, 2001 & $1 / 1 / 1987$ & AMLE & $4.7 \times 10^{6}$ & $1.9 \times 10^{6}$ & 40 & 83 \\
\hline 46 & 06882000 & 11,310 & $5 / 12 / 1987$ & $5 / 17 / 1990$ & 46 & 0 & 1971, 1994, 1997 & $1 / 1 / 1987$ & AMLE & $2.4 \times 10^{6}$ & $7.7 \times 10^{5}$ & 33 & 95 \\
\hline 47 & 06884025 & 7,125 & $5 / 12 / 1987$ & 4/18/1990 & 40 & 0 & 1995, 1996, 1998 & $1 / 1 / 1987$ & AMLE & $1.6 \times 10^{6}$ & $5.6 \times 10^{5}$ & 36 & 93 \\
\hline 48 & 06887000 & 24,960 & $5 / 13 / 1987$ & $4 / 26 / 1990$ & 43 & 0 & 1971, 1994, 1997 & $1 / 1 / 1987$ & AMLE & $2.6 \times 10^{5}$ & $7.5 \times 10^{4}$ & 29 & 88 \\
\hline 49 & 06888500 & 818.1 & -- & -- & -- & -- & -- & -- & AMLE & -- & -- & -- & -- \\
\hline 50 & 06891500 & 1,100 & $7 / 29 / 1987$ & $4 / 25 / 1990$ & 40 & 0 & 1946, 1970, 1997 & $1 / 1 / 1987$ & AMLE & $2.2 \times 10^{5}$ & $1.3 \times 10^{5}$ & 60 & 84 \\
\hline 54 & 06923150 & 106 & -- & -- & -- & -- & -- & -- & AMLE & -- & -- & -- & -- \\
\hline 56 & 06929315 & 88.55 & -- & -- & -- & -- & -- & -- & AMLE & -- & -- & -- & -- \\
\hline 58 & 06934500 & $1,353,000$ & $10 / 25 / 1996$ & 10/18/1999 & 50 & 0 & $1967,1971,1990$ & 1/1/1997 & AMLE & $1.2 \times 10^{8}$ & $1.5 \times 10^{7}$ & 12 & 77 \\
\hline
\end{tabular}

${ }^{1}$ The daily streamflow records corresponding to median years were applied to an artificial start date that was within the calibration time period. 


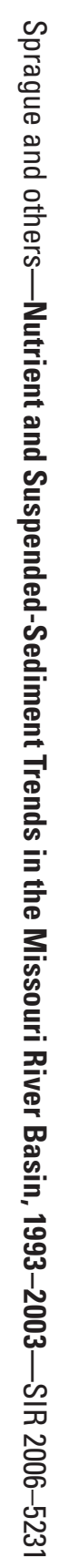

6 Printed on recycled paper 